UNIVERSIDADE DE SÃO PAULO

FACULDADE DE EDUCAÇÃO

Lucas Antonio Nizuma Simabukulo

O pensamento conceitual e o ensino de história na educação de jovens e adultos

São Paulo 


\title{
O pensamento conceitual e o ensino de história na educação de jovens e adultos
}

\begin{abstract}
Versão corrigida
(A versão original encontra-se na Biblioteca da Faculdade de Educação da Universidade de São Paulo e na Biblioteca Digital de Teses e Dissertações da USP)
\end{abstract}

Dissertação apresentada à Faculdade de Educação da Universidade de São Paulo para obtenção do título de Mestre em Educação.

Área de Concentração: Educação, Linguagem e Psicologia

Orientadora: Profa. Dra. Elizabeth dos Santos Braga

São Paulo 
AUTORIZO A REPRODUÇÃO E DIVULGAÇÃO TOTAL OU PARCIAL DESTE TRABALHO, POR QUALQUER MEIO CONVENCIONAL OU ELETRÔNICO, PARA FINS DE ESTUDO E PESQUISA, DESDE QUE CITADA A FONTE.

Catalogação na Publicação

Serviço de Biblioteca e Documentação

Faculdade de Educação da Universidade de São Paulo

\begin{abstract}
$375.42 \quad$ Simabukulo, Lucas Antonio Nizuma
S588p O pensamento conceitual e o ensino de história na educação de jovens e adultos / Lucas Antonio Nizuma Simabukulo; orientação Elizabeth dos Santos Braga. São Paulo: s.n., 2018.
\end{abstract}

$234 \mathrm{p}$.

Dissertação (Mestrado - Programa de Pós-Graduação em Educação. Área de Concentração: Educação, Linguagem e Psicologia) - Faculdade de Educação da Universidade de São Paulo.

1. História (estudo e ensino) 2. Educação de jovens e adultos 3. Formação de conceito 4. Psicologia 5. Sala de aula 6. Interação professor aluno I. Braga, Elizabeth dos Santos, orient.

Ficha elaborada por Natalina de Jesus Delfina da Luz - Bibliotecária CRB -4018 


\section{DEDICATÓRIA}

Dedico este trabalho à memória de meu irmão Kenzo, que muito me incentivou e encorajou desde criança. Dedico também a toda minha família: meus pais Julieta e Kenso, e meus irmãos Carla e Felipe.

Dedico também à minha companheira, Priscila, que durante esta pesquisa me cercou de compreensão, amor e, não raro, contribuições ao próprio trabalho acadêmico.

Dedico também a todos aqueles e aquelas que, com suor e lágrimas, não aceitam o desmonte da educação pública, e lutam por dias melhores. 


\section{AGRADECIMENTOS}

À Profa. Dra. Elizabeth dos Santos Braga, que desde que nos conhecemos muito me incentivou e, posteriormente, me orientou, com sua experiência e sua extensa indicação de leituras.

A todas as professoras das bancas de qualificação e defesa de Mestrado, pelas importantíssimas contribuições para este trabalho: Cláudia Lemos Vóvio, Giovana Azzi de Camargo e Marta Kohl de Oliveira.

Aos professores da Faculdade de Educação da USP com quem estudei na Pós-Graduação e que de muitas maneiras auxiliaram esta pesquisa ao longo do processo: Kátia Maria Abud, Kimi Aparecida Tomizaki, Teresa Cristina Rego e Valdir Heitor Barzotto.

À Faculdade de Educação da Universidade de São Paulo, com destaque aos funcionários da Secretaria de Pós-Graduação, sempre solícitos em auxiliar os alunos.

A toda a equipe gestora, professores, funcionários e alunos do CIEJA Aluna Jéssica Nunes Herculano, em especial à Coordenadora Pedagógica Laura Cymbalista, pelo apoio.

Por fim, a todos os gestores, professores, funcionários, responsáveis e alunos que passaram pela EMEF Synésio Rocha Min., com quem tenho tido a experiência de me fazer professor todos os dias. 
"Liberdade - essa palavra que o sonho humano alimenta: que não há ninguém que explique, e ninguém que não entenda!"

Cecília Meireles, Romanceiro da Inconfidência. 


\section{RESUMO}

SIMABUKULO, Lucas Antonio Nizuma. O pensamento conceitual e o ensino de história na educação de jovens e adultos. 2018. 234 f. Dissertação (Mestrado em Educação) - Faculdade de Educação, Universidade de São Paulo, São Paulo, 2018.

O presente trabalho traz, a partir da leitura de Lev S. Vigotski (1896-1934) e de outros autores da Perspectiva Histórico-Cultural, uma reflexão sobre a constituição do pensamento conceitual, nas aulas de História em uma turma de Educação de Jovens e Adultos. Nosso objetivo neste trabalho é investigar, a partir de um estudo de caso etnográfico, como nas interações dialógicas em sala de aula de EJA tem se constituído o pensamento conceitual em aulas de História, além de compreender como elementos do que autores da Didática da História chamam de consciência histórica emergem. A partir da pesquisa de campo em uma turma de EJA equivalente ao 6a ano, em uma escola pública municipal de São Paulo, analisamos quatro episódios, buscando identificar os diferentes discursos neles produzidos, a consciência histórica relacionada a eles, e como a escolarização possibilita (ou não) a formação do pensamento conceitual. Questionamos a visão um tanto preconceituosa de que os sujeitos pouco escolarizados seriam deficitários em seu desenvolvimento psicológico; de fato eles constroem significativos saberes a partir de suas vivências cotidianas. Contudo, não podemos desconsiderar as contribuições que a escolarização pode trazer em termos de desenvolvimento para esses sujeitos. A escola segue como uma importante instituição que possibilita um certo método de pensamento, pela sistematização de determinados conceitos.

Palavras-chave: Educação de Jovens e Adultos. Formação de conceito. Psicologia. História. Sala de aula. Interação professor-aluno. 


\section{ABSTRACT}

SIMABUKULO, Lucas Antonio Nizuma. Conceptual thinking and history teaching in the youth and adult education. 2017. $234 \mathrm{f}$. Dissertação (Mestrado em Educação) - Faculdade de Educação, Universidade de São Paulo, São Paulo, 2017.

The present work brings, from the reading of Lev S. Vigotski (1896-1934) and other authors of the Historical-Cultural Perspective, a reflection on the constitution of conceptual thinking, in History classes in a class of Youth and Adult Education. Our objective in this work is to investigate, from an ethnographic case study, how the dialogic interactions in Youth and Adult Education classroom has been constituted the conceptual thinking in classes of History, besides understanding how elements of which authors of the Didactics of History call it historical consciousness emerge. From the field research in an Youth and Adult Education class equivalent to the $6^{\text {th }}$ grade, in a public school in the city of São Paulo, we analyzed four episodes, seeking to identify different discourses produced in them, historical consciousness related to them, and how schooling enables (or not) the formation of conceptual thinking. We question the rather biased view that subjects with low schooling would be deficient in their psychological development; in fact, they build meaningful knowledge from their everyday experiences. However, we can not disregard the contributions that schooling can bring in terms of development for these subjects. The school continues as an important institution that makes possible a certain method of thinking, through the systematization of certain concepts.

Keywords: Youth and Adult Education. Concept formation. Psychology. History. Classroom. Teacher-student interation. 




1. Educação de Jovens e Adultos ..................................................... 13

1.1. A EJA no Brasil....................................................................... 13

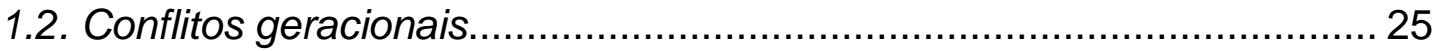

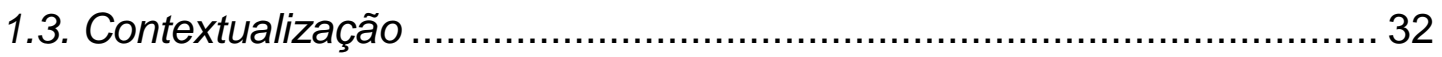

1.3.1. O CIEJA Aluna Jéssica Nunes Herculano..................................... 36

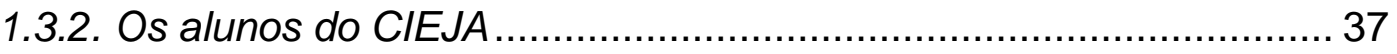

1.3.3. As instalações e o espaço físico da escola .................................... 41

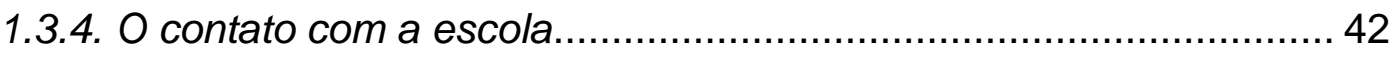

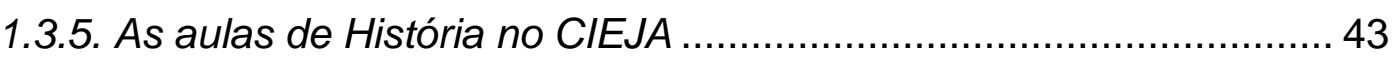

2. Teoria Histórico-Cultural e EJA ........................................................ 49

2.1. O trabalho precursor de Vigotski e Luria............................................. 49

2.1.1. Escolarização de jovens e adultos ............................................... 63

2.2. Escolarização e Teoria Histórico-Cultural ............................................. 73

2.2.1. O pensamento por conceitos: uma polêmica ...................................... 78

2.2.2 .O desenvolvimento do pensamento para Vigotski ......................... 84

2.2.3. Conceitos espontâneos e científicos ................................................. 90

2.2.4. Aprendizagem e desenvolvimento ................................................ 99

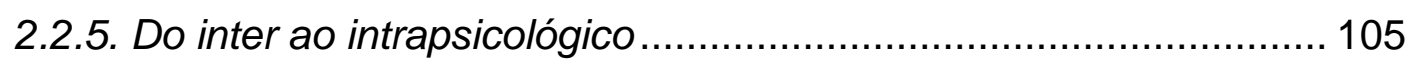

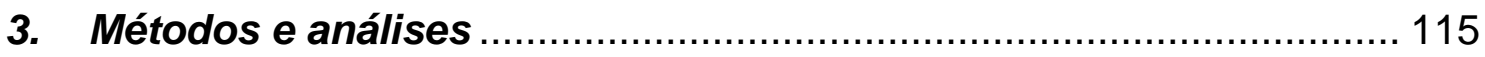

3.1. A pesquisa etnográfica em sala de aula .......................................... 115 
3.2.1. O papel da ideologia nas práticas discursivas ............................ 124

3.2.2. O discurso nas práticas escolares................................................ 132

3.2.3. Do socialmente construído para o psicologicamente constituído.. 140

3.3. Ensino de História e consciência histórica. 147

3.3.1. Experiência e expectativa na História 148

3.3.2. A Consciência Histórica para além da sala de aula 151

3.3.3. O conhecimento vicário e o Ensino de História 153

3.3.4. A constituição da consciência histórica em sala de aula. 156

3.4. Análise dos episódios: as relações em sala de aula. 166

3.4.1. A mediação em sala de aula 168

3.4.2. Sentidos e significados. 177

3.4.3. Processo de (re)criação 190

3.4.4. "Eu pensava que era assim!" 202

4. Considerações finais 222

5. Referências bibliográficas 227 


\section{Introdução}

O avanço do atendimento escolar da educação no Brasil nas últimas décadas sem dúvida é uma grande conquista histórica, especialmente para as camadas populares em um país com grandes desigualdades sociais como 0 Brasil. Por outro lado, a educação oferecida pelas políticas públicas não tem garantido plenamente $o$ acesso e a permanência dos alunos a uma escola pública de qualidade.

Essa situação faz com que, mesmo que as últimas gerações provavelmente tenham sido as mais escolarizadas da história do país, haja ainda um enorme setor da população jovem e adulta que não consegue concluir seus estudos. Essa população em geral recebe salários baixíssimos, e exerce trabalhos bastante precarizados. Vive em bairros periféricos, com graves problemas estruturais, nas grandes cidades (quando não em regiões rurais). A experiência escolar desses sujeitos é marcada por frustrações; além de não terem concluído a escola na idade que é considerada a ideal, é comum que tenham retornado e desistido da escola algumas vezes pelos mais diversos motivos.

A quantidade de jovens e adultos de famílias pobres que estudaram poucos anos na escola é tão grande que é comum que a sociedade naturalize essa situação. Ou seja, a falha nas políticas públicas não causa espanto. Algumas vezes, esses alunos atribuem a si mesmos a "culpa" por terem interrompido os estudos. A sociedade contemporânea convencionou que o lugar das crianças é "na escola" (e isso é uma grande conquista de direitos), mas pouco se escandaliza com jovens e adultos que têm o direito negado à educação. Por isso, entendemos ser de grande importância a realização de pesquisas sobre a Educação de Jovens e Adultos (EJA). É preciso desvendar esse universo para the dar visibilidade e pressionar por políticas públicas adequadas às necessidades da população.

As questões que norteiam este trabalho tiveram início anos atrás. No começo da minha carreira no magistério, como professor de História da rede 
pública do Município de São Paulo, havia algumas aulas disponíveis na EJA na escola em que trabalhava. $O$ receio inicial em ensinar pessoas mais velhas $\mathrm{e}$ jovens em situação de risco social logo foi substituído pela experiência de encontrar outra escola, bem diferente do Ensino Fundamental regular.

Nas salas, havia adultos com rugas e marcas de sol, apertados em carteiras feitas para crianças, com os olhos arregalados aguardando 0 professor começar a falar. Os mais velhos têm um respeito e reverência profundos pelo professor, e o desejo de aprender, como se pudessem por um momento retomar o tempo perdido. Ao mesmo tempo, muitos jovens (e o seu número foi aumentando ano a ano) eram responsáveis pelas brincadeiras e conversas mais altas nas salas e no corredor. Alguns inclusive cumprindo penas; as aulas eram parte da sentença da Justiça. Curioso como alguém empurrado pelas contradições da sociedade a cometer infrações (às vezes graves) se mostrava por vezes ótimo aluno nos debates em sala de aula, mostrando a diversidade de papeis sociais que os sujeitos são capazes de assumir. Por vezes, esses alunos contavam barbaridades inenarráveis que lhes acontecem na periferia de São Paulo. Outras vezes, os problemas chegavam à escola. Assim tem sido a minha experiência na EJA.

Como professor, me inquietava com a distância entre os conteúdos do Ensino de História e o conhecimento dos alunos. Concomitante a isso, anos atrás conheci a professora Elizabeth dos Santos Braga, como aluno especial na Faculdade de Educação da Universidade de São Paulo. Graças à mediação bem "vigotskiana" da professora, aos poucos, os escritos de Lev Semenovich Vigotski (1896-1934) e outros autores da Teoria Histórico-Cultural sugeriram algumas respostas, mas também provocaram algumas questões sobre os desafios que tinha como docente. Particularmente, a questão do pensamento por conceitos me interessou: compreender de que maneira os alunos, como sujeitos sociais e históricos, desenvolvem-se, aprendem e pensam. Dessa maneira, o presente trabalho traz, a partir da perspectiva da Teoria HistóricoCultural, uma reflexão sobre a formação do pensamento conceitual, nas aulas de História em uma turma de Educação de Jovens e Adultos. Muito 
contribuíram também para o desenvolvimento desta pesquisa as críticas e sugestões da banda de qualificação, formada pelas professoras doutoras Marta Kohl de Oliveira e Cláudia Lemos Vóvio.

Nesta pesquisa, nossa intenção não é em absoluto avaliar o trabalho pedagógico da escola onde realizamos a pesquisa empírica. É levantar algumas questões com relação à importância das práticas e saberes a respeito dos conhecimentos históricos que os alunos trazem à escola a partir dos chamados conceitos cotidianos, e que não podem ser menosprezados por não corresponderem às práticas escolares. Por outro lado, ressaltamos também a importância da educação formal e do Ensino de História, em oferecer um conhecimento a partir dos conceitos sistematizados (com todas as contradições epistemológicas que isso carregue), que têm sido tão negados a amplos setores da população jovem e adulta. Para tanto, é imprescindível aprofundar nossa compreensão sobre como operam os processos de desenvolvimento de modos de pensamento desses sujeitos na Educação de Jovens e Adultos. Assim, nosso objetivo neste trabalho é investigar, a partir de um estudo de caso etnográfico, como nas interações dialógicas em sala de aula, os sujeitos têm constituído o pensamento conceitual em aulas de História.

Na primeira parte deste trabalho, iniciamos com um breve histórico da Educação de Jovens e Adultos como política pública no Brasil, a fim de compreendermos que a alta demanda pela escolarização da população adulta foi uma constante ao longo da história, alvo de políticas em geral insuficientes, para dizer o mínimo, para a sua solução. Discutiremos também o tema dos conflitos geracionais, fenômeno presente na sociedade e que adentrou os muros da escola com a inserção de amplos setores da juventude nesse segmento. Por fim, introduziremos o leitor no CIEJA Aluna Jéssica Nunes Herculano, conhecido como CIEJA Butantã, unidade em que realizamos a pesquisa empírica.

Na segunda parte do trabalho, discutiremos as contribuições de Vigotski (1896-1934) e outros autores da Teoria Histórico-Cultural para o tema do pensamento conceitual. Considera-se, nessa perspectiva, que nas relações 
sociais e culturais historicamente construídas, constitui-se o desenvolvimento psicológico dos sujeitos particularmente pelas funções psicológicas superiores. Discutiremos também o impacto da escolarização, especificamente em sujeitos adultos, a partir da polêmica: sujeitos escolarizados têm um desenvolvimento intelectual qualitativamente superior em relação ao daqueles que não passaram pela escolarização formal?

No terceiro capítulo, apresentaremos, a partir do método do estudo de caso etnográfico, e das contribuições de autores da Filosofia da Linguagem como Bakhtin (1895-1975) e da Psicologia Discursiva, a nossa abordagem às interações no espaço escolar e às práticas sócio-ideológicas próprias da escolarização. Discutiremos também de que maneira a consciência histórica se constitui nas aulas de História entre alunos e professores. Além disso, serão apresentadas as análises de quatro episódios interativos da sala de aula pesquisada, a partir das reflexões teóricas realizadas. Investigamos como têm ocorrido as relações entre sujeitos em sala de aula, e o processo de formação de pensamento conceitual, com as possibilidades e limites da mediação pedagógica. 


\section{Educação de Jovens e Adultos}

No Brasil, a Educação de Jovens e Adultos, como política pública, se dá no contexto de uma sociedade vitimada por políticas educacionais insuficientes ou até mesmo equivocadas. A seguir, apresentamos um pequeno histórico da EJA no Brasil e na cidade de São Paulo, bem como uma breve reflexão sobre os conflitos geracionais. Por fim, neste capítulo, trazemos uma contextualização sobre a unidade escolar pesquisada, o CIEJA Aluna Jéssica Nunes Herculano.

\subsection{A EJA no Brasil}

Ao longo do período colonial, a maior parte das iniciativas da educação de jovens e adultos se dava a partir do trabalho dos jesuítas sobre os indígenas. Esse trabalho, claramente marcado pelo contexto histórico da catequização dos "gentios", é interrompido com a expulsão dos jesuítas no século XVIII.

A partir da independência da América Portuguesa e da Constituição de 1824, a educação aparece como um programa institucional excludente, pois não abrangia a massa de negros escravizados e indígenas. $\mathrm{O}$ acesso à escola era restrito inclusive aos considerados "cidadãos". De uma população de 14 milhões, apenas 250 mil crianças frequentavam a escola (HADDAD; DI PIERRO, 2000).

Durante a Primeira República, o Ensino Básico passou a ser, pela Constituição de 1891, responsabilidade das Províncias e Municípios, refém da sua fragilidade orçamentária e da boa vontade das oligarquias locais. Ao mesmo tempo, a maioria absoluta da população tinha uma cidadania bastante restrita, uma vez que os analfabetos (quase toda a população adulta) não poderiam votar ou serem eleitos. Em 1920,72\% da população acima de 5 anos não sabia ler ou escrever (Ibidem). Mesmo assim, foi nesse período que 
parcelas significativas da sociedade passavam a demandar a responsabilidade de educação pública por parte do Estado, e algumas reformas foram pensadas.

Na Era Vargas, particularmente a partir da Constituição de 1934, o Estado passava a intervir com um projeto, a partir do Plano Nacional de Educação. A educação pública passava a ser pensada como um direito universal, e pela primeira vez a educação de adultos passava a ser um destaque especial nas políticas públicas. Mesmo assim, a primeiras iniciativas significativas nesse sentido só seriam implementadas na década de 1940, após o enfraquecimento da ditadura do Estado Novo. Em 1945, estabeleceu-se que, do Fundo Nacional do Ensino Primário, $25 \%$ se destinariam ao Ensino Supletivo.

Segundo Haddad e Di Pierro,

\begin{abstract}
Em 1947, foi instalado o Serviço de Educação de Adultos (SEA) como serviço especial do Departamento Nacional de Educação do Ministério de Educação e Saúde, que tinha por finalidade a reorientação e coordenação dos trabalhos dos planos anuais do ensino supletivo para adolescentes e adultos analfabetos. Uma série de atividades foi desenvolvida a partir da criação desse órgão, integrando os serviços já existentes nessa área, produzindo e distribuindo material didático, mobilizando a opinião pública, bem como os governos estaduais e municipais e a iniciativa particular (HADDAD; DI PIERRO, 2000, p.111).
\end{abstract}

Nas décadas de 1940 e 1950 ocorreram, portanto, diversas iniciativas, mais ou menos exitosas, de políticas para a educação de jovens e adultos, em um patamar de política pública nacional. Isso se deveu em parte à pressão de uma enorme população, particularmente urbana (mas também rural), que demandava melhores condições de vida, por um lado, e à necessidade de qualificação de mão de obra para sociedades urbanas e industrializadas, por outro. Assim, a educação passava a ser vista como uma frente de intervenção do Estado, para o desenvolvimento nacional projetado nessas décadas. De fato, houve grande avanço na ampliação da rede pública (na década de 1950, 
$46,7 \%$ da população era analfabeta) em relação aos patamares do século XIX, embora ainda muito aquém da necessidade da população (HADDAD; DI PIERRO, 2000).

A partir do II Congresso de Educação de Adultos, em 1958 no Rio de Janeiro, diversas iniciativas foram tomadas, destacando-se o papel de Paulo Freire (1921-1997) em Pernambuco. Nesse momento, houve não apenas uma maior preocupação com a educação de jovens e adultos, mas um desenvolvimento qualitativo da concepção da educação para esse segmento. Chegou-se à conclusão de que, tradicionalmente, a educação para adultos reproduzia métodos utilizados no ensino infantil e básico, reforçando o preconceito com o analfabetismo das camadas populares e reforçando a exclusão. Concluía-se que uma educação que contasse com a participação ativa de sujeitos portadores de importantes saberes era necessária.

Durante as décadas de 1950 e 1960, a atuação dos governos brasileiros era fortemente marcada pelo desenvolvimentismo da economia, e também por um processo de abertura da economia e substituição de importações, particularmente durante o governo de Juscelino Kubitschek. O desenvolvimento econômico se deu a partir de contradições agudas, produzindo também grande desigualdade social e desemprego. Dessa maneira, a educação se tornou um espaço de disputa entre diversas vertentes políticas, buscando dar uma resposta à crescente insatisfação das camadas populares. Para Haddad e Di Pierro

É dentro dessa perspectiva que devemos considerar os vários acontecimentos, campanhas e programas no campo da educação de jovens e adultos, no período que vai de 1959 a 1964. Foram eles, dentro outros: o Movimento de Educação de Base, da Conferência Nacional dos Bispos no Brasil, estabelecido em 1961, com o patrocínio do governo federal; o Movimento de Cultura Popular do Recife, a partir de 1961; os Centros Populares de Cultura, órgãos culturais da UNE; a Campanha de Pé no Chão Também se Aprende a Ler, da Secretaria de Educação de Natal; e, finalmente, em 1964, o Programa Nacional de Alfabetização, do Ministério de Educação e Cultura, que contou com a presença do professor Paulo Freire (HADDAD; DI PIERRO, 2000, p. 113). 
Após o Golpe Cívico-Militar de 1964, a maioria dos programas dos governos nessa direção foi interrompida, as lideranças foram perseguidas e os materiais recolhidos, significando uma clara ruptura com a política sobre a educação de jovens e adultos do período anterior. Questionava-se o caráter ideológico e "popular" dessas iniciativas. Mesmo assim, não é possível afirmar que não houve resistência no sentido de manter projetos de educação popular, ainda que de maneira menos articulada e buscando não chamar a atenção dos agentes do governo militar.

Mesmo assim, a pouca escolaridade da população seguia como um "calcanhar de Aquiles" para um país que de alguma maneira ainda almejava se desenvolver segundo os parâmetros do capitalismo da época. Por isso, o governo deu origem ao MOBRAL (Movimento Brasileiro de Alfabetização) em 1967. Esse programa contava com relativa quantidade de recursos destinados; tinha alguma influência da antiga educação popular, levada a cabo por alguns funcionários que trabalhavam para o Estado, mas também correspondia a uma tentativa de o governo militar ganhar bases de apoio populares, em um período em que movimentos populares, sindicais e de parte da classe média eram duramente perseguidos pelos agentes da repressão.

O MOBRAL contava com um orçamento razoável para a época, era gerenciado em parte por "representantes locais", que normalmente incluíam empresários e membros do clero simpáticos ao regime, e seu programa era elaborado nacionalmente para todo o país. Eram realizados encontros grandiosos com supervisores de todo o país, para sustentar a ideologia do programa nas bases. Foi implementado pelo Governo, com o apoio da mídia e da imprensa como um programa de erradicação do analfabetismo no Brasil, sem maiores discussões político-pedagógicas com o conjunto da sociedade. $O$ MOBRAL realizou também parcerias com a iniciativa privada e as igrejas e se destacou quase como um programa à parte das Secretarias de Educação. Ao fim, o programa fracassou como tentativa de combate ao analfabetismo, não sem receber, ao longo da década de 1970, muitas críticas. 
A partir da LDB (Lei de Diretrizes e Bases) de 1971, iniciam-se as diretrizes para o Ensino Supletivo. Elaboradas em grande parte por Valnir Chagas, o Supletivo se destinava, a partir dos princípios da Ditadura Militar, a ser um sistema independente, mas integrado ao Ensino Regular; formação de mão de obra para o "desenvolvimento" nacional; e uma educação supostamente "neutra", diferente da antiga educação popular com forte conteúdo ideológico. A educação de adultos a passou ser, nos anos seguintes, uma formadora de mão de obra e uma promessa de ascensão social. Dessa maneira:

[...] a educação de adultos passou a compor o mito da sociedade democrática brasileira em um regime de exceção. Esse mito foi traduzido em uma linguagem na qual a oferta dos serviços educacionais para os jovens e adultos das camadas populares era a nova chance individual de ascensão social em uma época de "milagre econômico". O sistema educacional se encarregaria de corrigir as desigualdades produzidas pelo modo de produção. Desse modo, o Estado cumpria sua função de assegurar a coesão das classes sociais (HADDAD; DI PIERRO, 2000, p. 118).

A pressão de amplas parcelas da sociedade, dos movimentos sindical e estudantil, bem como o surgimento de novas organizações, direções e partidos, levaram ao desgaste da Ditadura Cívico-Militar na década de 1980. Como o MOBRAL era muito vinculado ao governo militar, e o serviço prestado era de qualidade duvidosa, o programa acabou sendo extinto. Os governos estaduais e prefeituras passaram a ter maior autonomia sobre a educação de jovens e adultos. No contexto da redemocratização dos anos 1980 muitas iniciativas que eram realizadas de maneira semiclandestina se ampliaram, e outras foram criadas, gerando um momento de bastante experimentação metodológica e didática. Grande parte dessa insatisfação se materializou, não sem graves contradições, na Constituição de 1988. A partir daí, o Estado passa a se responsabilizar pela educação de jovens e adultos como um direito universal, conflitando com a insuficiência das políticas públicas nos anos subsequentes. 
No plano internacional, declarava-se, na Conferência Mundial de Jontiem (Tailândia), a década de 1990 como a "Década da Educação para Todos".

Nos anos que antecederam e sucederam a grave crise política que ocasionou o impeachment do presidente Collor, a educação de jovens e adultos testemunhou a descontinuidade de políticas públicas no plano nacional e cortes de verbas. A pressão de organismos internacionais para empréstimos ao governo brasileiro, no entanto, fez o Brasil adotar a partir de 1994 um plano decenal de combate ao analfabetismo (HADDAD; DI PIERRO, 2000).

Ao longo dos anos 1980 e 1990, foi elaborada uma nova lei de Diretrizes e Bases da Educação. O antigo plano decenal não foi aplicado, e a nova Lei de Diretrizes e Bases foi aprovada em 1996 pelo Governo Federal. Para os autores,

\footnotetext{
A nova LDB 9.394, aprovada pelo Congresso em fins de 1996 foi relatada pelo senador Darcy Ribeiro, e não tomou por base o projeto que fora objeto de negociações ao longo dos oito anos de tramitação da matéria e, portanto, desprezou parcela dos acordos e consensos estabelecidos anteriormente (HADDAD; DI PIERRO, 2000, p. 121).
}

Mesmo assim, houve a integração da educação de jovens e adultos ao Ensino Regular, sem grandes inovações pedagógicas.

Também na década de 1990, foram amplos os debates sobre um novo Plano Nacional de Educação. Foram feitas várias propostas, e a síntese dos debates foi o Plano Nacional de Educação aprovado em 2001 (Lei № 10.172), que, embora em seu conteúdo não tivesse nenhuma grande novidade pedagógica, instituía a necessidade de erradicar o analfabetismo como dívida histórica da sociedade brasileira, a preparação para o mercado de trabalho, e a atenção aos direitos à educação de populações mais vulneráveis, particularmente a nordestina, feminina, negra a indígena. 
A partir da LDB, o governo iniciou, no contexto de aplicação de políticas neoliberais, a descentralização do repasse aos gastos com a educação e a prioridade ao Ensino Fundamental, fragilizando a EJA que teria que ser custeada por orçamentos locais (estaduais e municipais) e passaria a ser preterida em relação ao ensino regular. Ao contrário da Constituição de 1988, que previa metade do orçamento da educação para o combate ao analfabetismo, as reformas de 1995 criaram o FUNDEF (Fundo de Manutenção e Desenvolvimento do Ensino Fundamental e Valorização do Magistério), que repassaria verbas para os estados e municípios de acordo com o número de alunos matriculados, valor a ser regulamentado pelo governo federal, implicando em menos orçamento para a educação. Um dos vetos do governo federal ao texto original da Lei 9.424/96 excluiu os alunos da Educação de Jovens e Adultos da verba do FUNDEF, desestimulando os governos locais que já teriam dificuldades para custear a educação básica devido à municipalização - a priorizar o setor. Isso em um contexto em que a demanda de jovens e adultos com pouca ou nenhuma escolarização era imensa (HADDAD, DI PIERRO, 2000).

Devido à falta de recursos para a educação de jovens e adultos, houve iniciativas no fim dos anos 1990, mas com parcerias entre outros setores da sociedade. Dois deles foram, na prática, privatizações ou parcerias entre 0 governo e empresas: o PAS (Programa Alfabetização Solidária), que atuava mais nas periferias e cujo resultado foi bem aquém do esperado; o outro foi 0 PLANFOR (Plano Nacional de Formação do Trabalhador), com objetivo mais técnico, de qualificação profissional para pessoas com baixa renda. O seu alcance foi maior, mas evidentemente estava aquém de uma educação de qualidade que fosse além da formação de mão de obra.

Outra iniciativa dos anos 1990, capitaneada por universidades públicas, sindicatos e movimentos sociais, com verba federal, foi o PRONERA (Programa Nacional de Educação na Reforma Agrária). Embora sofrendo com a descontinuidade dos recursos, o programa foi capaz de alfabetizar mais de 55 mil pessoas, retomando, com atualizações, um modelo de educação para 
jovens e adultos baseado nas necessidades das camadas populares e na valorização da sua cultura.

Dessa maneira, os anos 1990 para a EJA foram marcados por uma concentração de currículos, materiais didáticos e avaliações, e uma descentralização no financiamento, jogando sobre Estados e Municípios quase que a total responsabilidade pela manutenção da EJA nas redes públicas. As metas de combate ao analfabetismo do Plano Nacional de Educação de 2001 foram audaciosas, mas a legislação seguiu a lógica da LDB de subinvestimento na Educação de Jovens e Adultos, delegando quase que exclusivamente para os Estados e Municípios a responsabilidade pelo setor.

Nos anos 2000, o governo investiu sensivelmente mais na Educação de Jovens e Adultos e criou mais programas para o setor. Após amplo debate nessa década, e pressão de diversos fóruns e instituições, a EJA recebeu um aumento no financiamento, a partir do FUNDEF, mas os resultados não foram satisfatórios, fazendo com que o Brasil não alcançasse (nem de longe) as metas de alfabetização a que se propôs no PNE. Em 2006, menos de $10 \%$ das pessoas com menos de 4 anos de escolaridade estavam frequentando a EJA (DI PIERRO, 2010). O cumprimento da meta do PNE no período de 2000/2010, de assegurar a EJA para $50 \%$ da população que não concluiu o Ensino Regular, foi um fracasso.

Outro dado interessante dessa década é que o número de alunos matriculados na EJA subiu de 3.624.264 em 2001 para 4.861 .390 em 2006. A partir daí, porém, as matrículas foram decaindo ano a ano.

Segundo o Censo de 2010, o Brasil tinha 13,2 milhões de cidadãos analfabetos. Em 2012, havia 27,8 milhões de analfabetos funcionais, ou seja, pessoas que tiveram menos que 4 anos de escolarização. Se somarmos, ao todo teríamos, no início da década, 41 milhões de pessoas que vivem excluídas em sua própria sociedade. Entre os mais pobres, o analfabetismo vitima $14 \%$ das pessoas. No Nordeste, chega a 17,4\%. Entre crianças e jovens, $36 \%$ não tem acesso à escola em alguma de suas etapas, gerando um 
"exército" de 13,6 milhões de crianças e jovens fora da escola. Essa será a futura demanda da EJA em alguns anos. Além disso, 14 milhões de jovens estão fora das séries adequadas para essa faixa etária. Se fizermos um recorte de classe social, gênero ou raça, a exclusão aumenta ainda mais que a média (GODEIRO; GURGEL, 2015).

O documento "A avaliação da EJA no Brasil: insumos, processos, resultados" (BRASIL, 2015), traz dados semelhantes:

Das 65 milhões de pessoas com 15 anos ou mais que não completaram o Ensino Fundamental, cerca de 1,3 milhão (2\%) estava de fato cursando a EJA no nível fundamental e outros 851 mil $(6,2 \%)$ estavam em classes de alfabetização de jovens e adultos, enquanto aproximadamente 4,9 milhões (7,5\%) estavam cursando 0 ensino fundamental regular com defasagem na relação idade/série ideal. Entre os 22 milhões que não completaram o Ensino Médio, cerca de três milhões $(14,7 \%)$ cursavam o ensino médio regular e 1,5 milhão $(7,2 \%)$ cursava a EJA-EM. Os dados evidenciam, portanto, que 0 atendimento do público potencial da EJA é mínimo, e que, mesmo estando parte da demanda sendo atendida pelo ensino regular, há parcela importante - 90,5\% para o EF e 77,9\% para o EM - que está fora da escola (BRASIL, 2015, p. 13).

O novo Plano Nacional de Educação, aprovado em 2014, não trazia grandes novidades para a EJA, embora reafirmasse a intenção de aprofundar a formação dos docentes em todos os níveis, ir contra várias formas de discriminação e combater o analfabetismo. Para Godeiro e Gurgel,

O elemento determinante para o não cumprimento dessas metas foi o subfinanciamento da educação por parte dos governos, principalmente do Governo Federal. Assim, o subfinanciamento e a prioridade dada ao crescimento da iniciativa privada são os elementos centrais que determinam que também o PNE 2014-2024 seja mais uma promessa de políticos do que um Plano de Governo, uma vez que estabeleceu metas importantes, porém, com financiamento insuficiente para atingi-las (GODEIRO; GURGEL, 2015, p. 40). 
Portanto, para esses autores, apesar de alguns relativos avanços na década de 2000 e no PNE de 2014, como a meta de se investir 10\% do PIB para a educação até 2024, ainda assim o financiamento para a educação foi e tem sido insuficiente, seja por causa dos desafios da sociedade brasileira (particularmente após a crise econômica a partir de 2013), seja porque parte desses recursos na verdade está se destinando para a iniciativa privada. Assim, o subinvestimento seria a principal razão pela qual as metas em geral não estarem sendo atingidas.

Outra mudança qualitativa que vem ocorrendo desde os anos 1980 é a presença cada vez maior de jovens na EJA. Se antes a escola era um espaço basicamente de adultos provenientes da Zona Rural, hoje é um espaço para jovens cuja experiência escolar foi conflituosa, desestimulante e descontínua:

Os jovens carregam consigo o estigma de "alunos problema", que não tiveram êxito no ensino regular, e que buscam superar as dificuldades em cursos aos quais atribuem o caráter de aceleração e recuperação. [...] Assim, os programas de educação escolar de jovens e adultos, que originalmente se estruturaram para democratizar oportunidades formativas a adultos trabalhadores, vêm perdendo sua identidade, na medida em que passam a cumprir funções de aceleração de estudos de jovens com defasagem série-idade regularização do fluxo escolar (HADDAD; DI PIERRO, 2000, p. 127).

No município de São Paulo, o documento "Reorganização da EJA Educação de Jovens e Adultos: Rede Municipal de Ensino de São Paulo", publicado em 2008 pelo governo municipal, com parecer do Conselho Municipal de Educação, e vigente quando da pesquisa realizada em sala de aula em 2015, afirmava que

A Reorganização da Educação de Jovens e Adultos - EJA no Município de São Paulo estabelece a democratização como meta, tanto no sentido de propiciar pleno atendimento da demanda, em escolas e oferta de educação profissional em polos regionais, quanto no esforço intencional da reorganização 
para garantir a permanência desses alunos até o final da última Etapa, com adequada aprendizagem ao longo de todo o curso (SÃO PAULO, 2008, p. 23).

A EJA era dividida em quatro Etapas anuais, sendo as duas primeiras voltadas para a alfabetização, e as duas últimas para as várias áreas do conhecimento. O currículo é o das disciplinas tradicionais do Ensino Fundamental, mas com alguma abertura para o desenvolvimento de projetos voltados para a especificidade da EJA. O documento ressalta a importância do ensino profissionalizante, da contextualização de uma educação para esse público especifico, e a flexibilidade nas práticas pedagógicas.

O governo municipal de São Paulo publicou ainda outra proposta para a EJA, intitulada "Educação de Jovens e Adultos: princípios e práticas pedagógicas" (2016). Há uma recuperação de Paulo Freire como referência teórica para a Educação de Jovens e Adultos, com grande destaque para questões como cultura popular, raça, gênero e orientação sexual. Essa proposta afirmava que

Para além do conhecimento do perfil dos educandos, a proposta de reorientação curricular para a EJA alicerça-se, em uma educação humanista e popular, comprometida com a construção de um novo saber realmente libertador e significativo, levando em conta o acesso à produção cultural da humanidade (SÃO PAULO, 2016, p. 22).

Em ambas as propostas, encontra-se uma tentativa de síntese entre a educação como direito (particularmente a preocupação com a alfabetização), por um lado, e uma formação profissionalizante, por outro. As duas também ressaltam a particularidade dos alunos da EJA em serem sujeitos com amplos e complexos saberes, que devem ser levados em conta no seu processo educativo. A proposta de 2016 destaca um pouco mais a cultura popular e 0 fato de que entre os alunos há grande proporção de negros, mulheres e 
LGBT's (Lésbicas, Gays, Bissexuais, Transexuais e Travestis). No entanto, nas décadas de 2000 e 2010, quando estes últimos programas para a EJA foram implementados pelos governos municipais, não foram poucos os problemas. Ambas foram elaboradas com limitada participação de professores e comunidades escolares, e os resultados foram questionáveis.

Na rede municipal de São Paulo, havia em 2014, 209 escolas públicas municipais que ofereciam a Educação de Jovens e Adultos, 02 CMCT's (Centro Municipal de Capacitação e Treinamento) e 540 classes de MOVA (Movimento de Alfabetização de Adultos). Segundo o INEP (Instituto Nacional de Estudos e Pesquisas Educacionais Anísio Teixeira), no período de vigência do Plano Nacional de Educação de 2001 (2001-2013), houve um crescimento constante de matrículas de alunos da EJA no Município de São Paulo. Em 2001, havia 131.221 matrículas; o auge foi em 2004 quando se chegou a 149.662 matrículas. Houve alguns anos com quedas bruscas, seguida de uma raquítica recuperação, até que a partir de 2008 as matrículas passaram a despencar constantemente, chegando em 2014 a apenas 52.421 matrículas. De 2004 (ano com mais matrículas) até 2014, houve uma queda de matrículas na EJA em São Paulo de 65\%. Portanto, apesar das propostas dos governos municipais em seus documentos para a EJA, a evasão se agravou de maneira preocupante. Na prática, esses planos governamentais falharam, pois os mecanismos que levam à exclusão de jovens e adultos do espaço escolar se aprofundaram, inclusive com fechamento de turnos de EJA nas escolas municipais por parte dos próprios governos que elaboraram essas propostas.

Em São Paulo, a Educação de Jovens e Adultos é distribuída na rede pública municipal em três modalidades: a EJA - Noturno, a EJA Modular, e o CIEJA (Centro Integrado de Educação de Jovens e Adultos). A EJA - Noturno é organizada com quatro Etapas de dois semestres cada (Alfabetização, Básica, Complementar e Final) e é oferecida no período noturno das escolas municipais. A EJA modular também ocorre no período noturno das escolas municipais. São oferecidos módulos bimestrais com duas disciplinas, cada uma com duas aulas por semana com duração de duas horas e quinze minutos; 0 
restante da carga horária é destinada para projetos especiais que servem também para "compensar" faltas dos alunos.

Há também outras duas modalidades de EJA que não ocorrem em unidades educacionais da rede pública direta. O MOVA é uma parceria entre a prefeitura e organizações da sociedade civil. Seu foco é na alfabetização. As aulas ocorrem em igrejas, creches e empresas, duram duas horas e trinta minutos, quatro vezes por semana. Já o CMCT possui duas unidades na cidade e seus cursos se destinam à qualificação profissional de mão de obra.

O CIEJA é distribuído por dezesseis unidades pelo Município de São Paulo. É a única modalidade a ocorrer em uma escola pública direta da prefeitura que abarca apenas a EJA, nos três períodos. As aulas ocorrem também em "módulos" com duração de um bimestre, com duas disciplinas cada. Essas aulas ocorrem quatro vezes por semana; na sexta, os alunos realizam atividades diferentes das matérias tradicionais, com cursos e atividades oferecidas pelos próprios professores, de acordo com o Projeto Político Pedagógico da escola. Os professores que trabalham no CIEJA são funcionários públicos concursados da rede municipal. São abertas inscrições anualmente para os professores da rede que quiserem trabalhar no CIEJA. Os professores passam por etapas seletivas (entrevista, prova escrita, pontuação funcional) e caso aprovados, precisam ser designados pelo Secretário de Educação. Assim, toda a escola estaria voltada exclusivamente para 0 atendimento dos alunos jovens e adultos.

\subsection{Conflitos geracionais}

A Educação de Jovens e Adultos no Brasil foi por muitos anos uma política voltada para adultos trabalhadores e pouco escolarizados, que queriam concluir o ensino básico. Embora haja ainda grande quantidade desses nas salas de aula da EJA, tem aumentado a presença de adolescentes com trajetória bastante conflituosa com a escola. Dessa maneira, acirram-se os 
conflitos geracionais na EJA, pois aparentemente adultos e adolescentes podem vir a ter interesses diferentes na escola e na sociedade.

Segundo o documento "A avaliação da EJA no Brasil: insumos, processos, resultados" (BRASIL, 2015), há uma quantidade cada vez maior de jovens matriculados nos cursos de EJA no Brasil:

\begin{abstract}
Se a oferta de EJA estivesse totalmente adequada à demanda, esperaríamos que a distribuição da idade entre os que frequentam e os que não frequentam de fato a EJA fosse a mesma. Porém a distribuição etária dos alunos que declaram estar matriculados na EJA é bem diferente da distribuição dos que não a frequentam. Os mais jovens desse público potencial, especialmente nas faixas entre 18 e 24 anos, estão mais presentes entre os que frequentam a EJA (oferta) do que entre os que não a frequentam (demanda) (BRASIL, 2015, p. 13).
\end{abstract}

O documento ainda traz o número de alunos por faixa etária que não concluíram o ensino fundamental, mas frequentavam as redes de ensino. Em 2010, havia em todo o país 558.746 alunos matriculados entre 15 e 19 anos, 157.939 entre 20 e 24 anos, 128.562 entre 25 e 29 anos, 215.872 entre 30 e 39 anos, 137.730 entre 40 e 49, e 124.300 alunos com 50 anos ou mais (Brasil, 2015). Como se pode perceber, o número de alunos adolescentes ou jovens que não concluíram o ensino fundamental, mas que estavam matriculados (ou no ensino regular com defasagem na idade/série, ou na EJA), é imenso, comparado ao dos adultos.

A presença de jovens na EJA evidenciou o fenômeno dos conflitos geracionais na escola. Esses conflitos muitas vezes são gestados fora da escola, mas sua rota de colisão frequentemente se dá no interior da sala de aula. A EJA deveria, portanto, ser pensada a partir da perspectiva desses conflitos, pois a questão geracional está imbricada nas relações entre os sujeitos que frequentam esse segmento. 
A diferença entre jovens e adultos nem sempre é evidente como parece. A partir de que momento um jovem se torna um adulto apto a todas as responsabilidades do mundo do trabalho ou da vida pública? E os adolescentes que desde cedo ocupam postos de trabalho informal ou precarizado, seriam adultos "precoces"? Qual o papel da maternidade ou paternidade para a divisão entre a geração mais nova, alvo de cuidados, para aquela que é responsável pelos filhos? É comum, por exemplo, vermos na EJA indivíduos de pouco mais de 20 anos que reproduzem comportamentos típicos da adolescência, e outros com a mesma idade cronológica que se vestem e se portam como adultos, se confundindo com os mais velhos.

A discussão pode ser aprofundada, se pensarmos que no interior de ambas as categorias - jovens e adultos - haveria também subgrupos ou no mínimo uma diversidade de modos de ser. Há jovens inseridos em diversas culturas urbanas, como hip hop, bailes funk, le pakour, skate, e muito outros; há adultos que ocupam as mais variadas atividades econômicas, culturais e políticas. Além disso, onde se encaixariam os idosos na EJA? Seus interesses são os mesmos dos adultos que estão mais ativos no mundo do trabalho? Assim, há muitas formas de ser jovem ou adulto.

Talvez o maior precursor do estudo sobre os conflitos geracionais tenha sido o pensador húngaro Karl Mannheim (1893 - 1947). Em seus estudos pioneiros sobre o tema das gerações, Mannheim (1993) sugere ao menos quatro características sobre este fenômeno. O primeiro consiste em que na sociedade há sempre novos portadores da cultura. Isso significa que as novas gerações estão sempre nascendo e se desenvolvendo, desafiando com suas demandas a sociedade que já se encontra organizada a encontrar mecanismos de acolhimento, ajuste ou dominação sobre eles.

Um segundo aspecto levantado pelo autor a respeito da problemática das gerações é a saída constante dos antigos portadores da cultura. Com a morte constante das velhas gerações, a sociedade precisa encontrar mecanismos para tornar presente o passado (ou o que se seleciona dele) através da memória. 
Uma terceira característica da problemática das gerações para Mannheim é o fato de que os portadores de uma conexão geracional apenas participam em um período, do processo histórico temporalmente determinado. Viver no mesmo período que outros indivíduos da mesma idade (ou do mesmo coorte) não garante que se constitua uma geração do ponto de vista sociológico. Para constituir uma geração, é necessário que esses indivíduos com idades cronológicas semelhantes partilhem de uma mesma vivência sóciohistórica. Determinados acontecimentos históricos são tão significativos para certas gerações que levam ao que Mannheim (1993) chama de uma "estratificação da experiência" desses sujeitos. A partir de uma experiência histórica comum, partilhariam uma certa visão de mundo, compreensível totalmente apenas àqueles que pertencem a determinada geração.

Um quarto elemento da questão geracional apontado pelo autor seria a necessidade de transmissão constante dos bens culturais. A tradição é necessária porque simplesmente as velhas gerações morrem, e com elas 0 risco de que conhecimentos significativos e necessários para os jovens se percam. Algumas vezes, esses conhecimentos são passados inconscientemente, de forma que nem os mais velhos nem os mais jovens estejam necessariamente orientados para o ensino e aprendizagem dos valores sociais, embora ocorra a transmissão.

Para Attias-Donfut (1988), apesar da imensa contribuição de Mannheim, ele aparentemente aprofunda pouco a noção da identidade das gerações, no que tange à alteridade e o conflito entre elas. Uma geração só se constitui como tal em relação a outras, anteriores e posteriores.

Para a autora, o que se poderia afirmar é que em primeiro lugar, a geração a que um indivíduo pertence medeia a sua consciência histórica. A sua localização geracional, sendo uma experiência única em relação a outras, mas comum em relação a alguns de seus coetâneos, constituiria muito da sua relação com a sociedade, a história, e a memória coletiva. Essa experiência diferenciada (em relação a outras gerações) e comum (em relação aos que possuem a mesma idade cronológica) provocaria inclusive um conflito cognitivo 
entre gerações, pois cada uma pertenceria a diferentes camadas históricas que coexistem contemporaneamente e teria suas consciências individuais constituídas de forma diferenciada historicamente.

Outro elemento importantíssimo dessa discussão é o fato de que, não obstante falarmos de jovens e adultos, estamos falando de jovens e adultos em mudança no tempo. Para Motta (2010), eles não estão estáticos em seus ciclos de vida, mas em constante processo de envelhecimento. Além das mudanças físicas provocadas pela maturação do organismo, vão aos poucos recebendo outros papeis impostos pela sociedade, reagindo a eles e constituindo outras identidades ao longo das suas trajetórias de vida. Jovens não serão jovens para sempre e, ao longo da vida adulta, muitas transformações os aguardam.

Para a autora, poder-se-ia afirmar que as relações entre gerações são sempre conflituosas. Porém, diferentemente de outros tipos de conflito, além de uma disputa por poder, há também vínculos, laços de afetividade imbricados nestas lutas. Ao longo do tempo, a mudança de papeis e posições geracionais alimenta esse conflito, reestruturando constantemente o jogo de poder. Um exemplo é a inversão que há quando os adultos de uma família ou comunidade cuidam e exercem poder sobre as crianças durante um tempo, mas depois de anos se tornam idosos e se veem sob os cuidados (ou a dominação) das antigas crianças, agora adultos.

Para Duarte e Gomes (2008), haveria um processo de reestruturação produtiva nas últimas décadas no mundo todo, particularmente no Brasil, ocasionando um deslocamento geográfico de mão de obra, fechamento de postos de trabalho e abertura de outros, geralmente mais precarizados, privatizações de serviços públicos conjugados com uma oferta insuficiente desses mesmos serviços como saúde, transporte e educação, aumento do desemprego e da economia informal. No Brasil, esse processo é ainda mais grave, dada a modernização contraditória pela qual passou o país ao longo do século XX. 
Segundo os autores, a reestruturação produtiva, como fenômeno histórico das últimas décadas, impõe mudanças que são incorporadas de diferentes maneiras nos mais variados segmentos da população. Passa a ser inevitável que haja mudanças sociais e culturais entre gerações, pois as novas gerações precisam se adaptar a essas mudanças no mercado, e dificilmente isso ocorre sem conflitos com a geração mais velha. Ocorreria um "desenraizamento" dos indivíduos em função dessas mudanças. Os conflitos geracionais, das últimas décadas não se dariam apenas devido ao fato de as diferentes gerações terem práticas sociais ou visões de mundo diferentes, mas porque o próprio contexto histórico da reestruturação produtiva teria ocasionado uma fratura geracional nas camadas populares, empurrando as novas gerações a assumir modos de vida (ocupações no mundo do trabalho, migrações, contato com outras culturas) diversos das gerações precedentes.

Como essas mudanças impactam a escola? Em sua interessante pesquisa sobre conflitos geracionais em famílias operárias na França, Beaud e Pialoux (1999) afirmam, sobre a expansão da educação, que as aspirações não conquistadas pelas gerações mais velhas, no contexto da reestruturação produtiva das últimas décadas, são projetadas por elas nas mais novas, e um dos caminhos vislumbrados seria a possibilidade de educação. Contraditoriamente, a expansão do ensino na França não corresponde àquela escola pretendida pelos pais quando eram mais novos, lançando as gerações mais novas em outro modelo educacional que cumpriria apenas parcialmente 0 desejo dos pais, o que de fato é sentido pelos mais jovens.

Nesse estudo, para os pais, a escola ocuparia também um lugar contraditório. Esperam dela que seja uma preparação para o mundo do trabalho, e gostariam que os filhos completassem a formação acadêmica a que não tiveram acesso. Têm uma representação de escola ideal herdada da escola tradicional, da educação formal que as gerações mais antigas, ou eles mesmos, tiveram. Mas não escondem o ressentimento com suas experiências com o mundo do trabalho e com a própria escolarização, demonstrando não compreender o funcionamento real da instituição escolar. Fica claro um choque 
cultural também entre os trabalhadores e a instituição escolar, em que o que está em jogo é o destino dos filhos.

O que nos interessa aqui é pensar como o contexto sócio-histórico das transformações no mundo da produção na França, provocaria cisões entre as expectativas das diferentes gerações em relação ao trabalho. As diferenças entre jovens e adultos não residem essencialmente em um conflito provocado pela diferença de idade entre uns e outros, mas pelas tensões que a própria sociedade ainda não resolveu, por estar ainda no processo de profundas e longas transformações econômicas e sociais.

Por fim, algumas considerações sobre a relação entre os conflitos geracionais e a Educação de Jovens e Adultos. A escola em geral e, em especial, a EJA, está ocupada por sujeitos jovens que em todo momento questionam a cultura escolar estabelecida. Nesse sentido, longe de negligenciar a questão da juventude, poderíamos, ainda assim, nos perguntar: uma escola sem esses conflitos é possível? Até que ponto seria até mesmo desejável?

Se a escola pretende ser um espaço de produção de saberes e democratização do conhecimento acumulado pela humanidade, seria de se esperar que os desafios demandados pelas novas gerações não causassem tanta estranheza. Se na dinâmica de funcionamento da sociedade está o fato de que sempre haverá novas gerações, criadoras de novas formas de sociabilidade, então a EJA não deveria estigmatizar os jovens e consequentemente naturalizar os conflitos geracionais (o que inclusive tende a torná-los mais violentos pela sua não resolução), e sim fazer da mediação dos conflitos geracionais parte intrínseca do seu projeto político pedagógico.

A própria nomenclatura do segmento separa dois grupos na mesma política pública: "jovens" e "adultos". Pressupõe-se então que são diferentes, mas deveriam estar juntos. São raríssimas, todavia, as tentativas de mediação de conflitos entre essas diferentes gerações, principalmente com relação às diferentes memórias e experiências que teriam. Na prática, espera-se que a 
mera convivência no mesmo espaço físico garanta essa troca de experiências, que ocorreria de maneira espontânea e fora de uma intenção pedagógica orientada, em uma espécie de laissez-faire.

Os adultos acumulam anos de experiência no mundo do trabalho, na relação com as leis e o Estado, na constituição de um núcleo familiar, nas culturas ligadas às religiões e a movimentos sociais, na experiência marcada pela migração do mundo rural para o urbano. Muitos relatam situações de miséria e profunda carência material no passado. Os jovens, talvez um pouco mais integrados ao mundo urbano e suas culturas como o funk e o hip-hop, e às novas tecnologias (ainda que se apropriando delas à sua maneira), trazem outra postura com relação ao vestuário, à sexualidade, às drogas. Os conflitos geracionais, advindos de intensas transformações econômicas, culturais e sociais, nas últimas décadas, chegam à escola sem que ela na grande maioria dos casos dê conta de mediar de uma forma adequada essas diferenças. Perde a escola e perdem os alunos, de diferentes gerações, que poderiam se enriquecer a partir dos relatos das experiências e memórias entre gerações, em busca de uma síntese entre diferentes práticas sociais e modos de ver e pensar o mundo.

Por fim, essa mediação seria necessária não apenas entre gerações diferentes, mas entre diferentes grupos sociais dentro da mesma geração. Os jovens não são todos iguais, tampouco os adultos. É preciso perceber também as particularidades no interior de uma mesma geração, apesar de estarem relacionadas às demandas de um mesmo contexto sócio-histórico.

\subsection{Contextualização}

A educação tradicionalmente é uma área de destaque nas políticas públicas, alvo de diversos programas constantemente alardeados pelas propagandas oficiais. Matérias sobre os mais diversos temas relativos a ela são encontradas nos jornais impressos, revistas e sites; também são muito comuns 
comentários no rádio e reportagens nos jornais televisivos sobre projetos educacionais exitosos em algum lugar do país ou do mundo. Por outro lado, é constante também a veiculação midiática de "escândalos" envolvendo a rede pública, destacando-se casos de violência de vários tipos entre alunos e professores, bem como pouca solidariedade às conhecidas greves de professores.

Na sociedade contemporânea, industrializada e organizada em Estados nacionais, a educação é concebida como uma área prioritária, em que pesem as limitações dessas ações nas últimas décadas. Diferente dos períodos históricos precedentes, praticamente não se concebe a formação das novas gerações fora da escola. As famílias ainda desejam que seus filhos estudem, de preferência até o ensino superior, mesmo que a escola já não garanta a colocação profissional de antes. Há um senso comum de que "lugar de criança é na escola", esteja essa escola em que estado estiver.

Há, no entanto, aqueles sujeitos cuja experiência escolar foi limitada e excludente: um exército de jovens e adultos cuja escolarização, a despeito da suposta prioridade que a educação recebeu nas últimas décadas, foi interrompida ou descontinuada. O atraso na universalização da educação no Brasil produziu gerações de adultos que não completaram sua experiência escolar, fato esse que traz uma série de dificuldades econômicas, políticas e culturais de inserção desses sujeitos em sua própria sociedade.

Eles constituem um grupo extremamente heterogêneo, mas com alguns elementos comuns. Situa-se nas camadas populares, grande parte moradores das periferias das grandes cidades, sofrendo toda a precariedade dos serviços públicos nessas regiões. Ocupam, em sua maioria, postos de trabalho extremamente precarizados, com condições de trabalho não raro análogas às da escravidão (sem carteira assinada, sem direitos trabalhistas básicos, "trabalhando por conta"). Grande parte desses adultos é negra e feminina, migrante da região Nordeste do país, ou seus descendentes. Possuem considerável experiência e conhecimentos adquiridos fora da educação formal, no mundo do trabalho, nas formas de sociabilidade da própria comunidade ou 
periferia, nas práticas sociais e políticas como associações de bairro e movimentos sociais, ou ainda em práticas culturais religiosas (cristãs, afrobrasileiras, espíritas, etc.), esportivas (campeonatos de bairro), saraus e apresentações teatrais e musicais. Subjetivamente, muitos se sentem responsáveis pelo seu fracasso escolar, que não veem como produto de uma política pública equivocada dos governos nas últimas décadas e das contradições sociais da própria sociedade de classes. Pelo contrário, atribuem a si próprios a culpa pelo abandono da escola, por inadequação ao espaço escolar ou necessidade de trabalhar.

Para esses, o segmento reservado na educação é o da Educação de Jovens de Adultos, política implementada nacionalmente e na Prefeitura Municipal de São Paulo. Novamente, a propaganda oficial contrasta com a realidade. Nos sites dos governos federal, estadual e municipal, são feitos diversos destaques para a Educação de Jovens e Adultos, mas são comuns a dificuldade dos alunos em conseguir as vagas e as reivindicações de professores por melhores condições de trabalho.

O retorno desses jovens e adultos à escola costuma ser carregado de sentimentos negativos, como a vergonha e a baixa autoestima. São aqueles que enfrentam as pressões da família e do trabalho, que muitas vezes desestimulam esse passo na vida pessoal. No caso das mulheres, muitas relatam nas aulas serem pressionadas a permanecer em casa para "fazer a janta" para os maridos, "cuidar" das crianças e idosos em casa, dar conta do trabalho doméstico à noite, quando já retornaram do trabalho profissional, ou meramente por "ciúmes" dos companheiros. No trabalho, muitos ocupam postos de trabalho extremamente precários e são vulneráveis a assédio moral e abuso das chefias, que impõem dificuldades para que os alunos saiam do ambiente de trabalho a tempo de estarem na escola à noite. Como os cursos de EJA normalmente são realizados no período noturno, os alunos tem de lidar com a violência nos bairros. São relativamente comuns os relatos de assaltos no entorno da escola, violência policial contra os jovens (particularmente os negros) e o medo constante das mulheres da violência sexual no retorno para 
casa. Tudo isso desestimula os alunos e são pressões que causam grande evasão nos cursos noturnos.

Além da dificuldade advinda do cotidiano das camadas populares para retornarem à escola, nem sempre a EJA é oferecida a essa população. Ao longo dos anos, tem sido comum o fechamento desses turnos noturnos, justificados pela "contenção de gastos" e uma suposta "falta de demanda" de alunos. Na prática, como a vida desses jovens e adultos é muito instável, devido ao desemprego ou subemprego, à precariedade da moradia e à violência, a falta de uma escola próxima que ofereça a Educação de Jovens e Adultos fecha de vez a possibilidade de retorno aos estudos.

$\mathrm{Na}$ escola, sentem-se deslocados ocupando um lugar que "naturalmente" caberia às crianças. As próprias unidades escolares não parecem estar preparadas para receber esse público. Em geral, os alunos da EJA sentam-se em carteiras feitas para crianças pequenas. Bebem água em bebedouros baixos, o que causa constrangimento para as mulheres que precisam se abaixar. Os banheiros são precários, nem sempre tendo instrumentos e utensílios básicos, como sabão, portas, papel, espelho, bancos de privada, causando situações embaraçosas a todos, particularmente aos mais velhos. O material didático nem sempre é entregue pelos governos, e em geral é de qualidade duvidosa.

Do ponto de vista pedagógico, tradicionalmente a prioridade das escolas é o Ensino Fundamental regular. Por isso, não é raro que em reuniões pedagógicas ou horas-coletivas não se priorizem as necessidades dos alunos da EJA, tampouco que se estude bibliografia específica para esse segmento. Dessa maneira, não se produz conhecimento suficiente entre os docentes a respeito das especificidades da EJA. 


\subsubsection{O CIEJA Aluna Jéssica Nunes Herculano}

A unidade escolar que estudamos é conhecida tradicionalmente no bairro como CIEJA Butantã, mas desde 2011, passou a chamar-se CIEJA Aluna Jéssica Nunes Herculano. Seu nome é em homenagem a uma ex-aluna da escola. Jéssica era portadora da Síndrome de Williams, tendo tido muita dificuldade ao longo de sua vida para ter o seu problema diagnosticado e devidamente tratado, além de ter esbarrado em muitas situações de exclusão nas escolas pelas quais passou. Por fim, estudou no CIEJA do Butantã, sua última escola. Faleceu por complicações advindas de uma cirurgia em 2010, não sem antes se tornar um símbolo da luta dos portadores da Síndrome de Williams ${ }^{1}$.

Em 2015 quando fizemos a pesquisa de campo, a escola possuía 445 alunos matriculados e dez salas de aula. Contava com 25 servidores (trabalhadores diretos) atuando nele, sendo 3 na gestão, 10 no quadro de apoio e 12 professores. Há também alguns trabalhadores terceirizados nas áreas da limpeza, alimentação e segurança. Além das 10 salas de aula, a escola possui também uma sala de informática e um banheiro especial para alunos deficientes.

Segundo o PPP (Projeto Político Pedagógico) de 2016 da escola, a unidade escolar se propõe a combater a evasão escolar dos alunos da EJA e em aprofundar o debate sobre multiplicidades, discutindo as questões de gênero, sexualidade, raça e etnia.

Em 1999 foi fundado o CEMES (Centro Municipal de Educação Supletivo). Nele, o curso era semipresencial; os alunos recebiam uma apostila e iam à escola eventualmente para realizar as provas e tirar dúvidas das matérias. Eram realizadas muitas oficinas e a escola deveria ser um espaço de

\footnotetext{
${ }^{1}$ Sua história de vida está registrada no site da Associação Brasileira da Síndrome de Williams (http://swbrasil.org.br/relatos/jessica-nunes-sao-paulosp/), contada por ela mesma.
} 
convivência entre os alunos (contraditoriamente ao caráter semipresencial). A proposta era de que os professores integrassem as diferentes disciplinas.

A partir de 2001, o CEMES passa por uma paulatina reestruturação que seguiu pelos próximos anos. São criados quatro módulos, trabalhados em turmas presenciais que ocuparam seis períodos, com duas horas e quinze minutos de duração cada. Em 2003, o tema da diversidade passou a ser bastante trabalhado na escola, e foram estabelecidas três grandes áreas do conhecimento: "Linguagens e Códigos" (Português, Artes, Inglês, Educação Artística e Informática), "Ciências Humanas" (História e Geografia) e Ciências Exatas (Ciências e Matemática).

Em 2005, a prefeitura pede que se priorizem as "competências leitora e escritora". Aos poucos, o ClEJA vai adotando uma proposta "sócioconstrutivista", cujo objetivo é trabalhar os conteúdos escolares de maneira contextualizada e significativa, através de "itinerários formativos" que funcionam como "fios condutores" dos temas.

Também segundo o PPP da escola, os alunos poderiam ser divididos em quatro principais grupos: jovens e adultos trabalhadores, jovens e adultos com necessidades especiais, adolescentes expulsos ou evadidos de escolas regulares e idosos. Até 2009, o CIEJA havia realizado 6000 matrículas ao longo da sua existência, com uma média de 800 a 1000 atendimentos por ano. Desde então, a cada ano, 300 a 350 alunos concluíram o Ensino Fundamental na escola.

\subsubsection{Os alunos do CIEJA}

O Projeto Político Pedagógico de 2016 traz também resultados interessantes de pesquisas que a escola realizou sobre o perfil dos alunos do período anterior, ano em que foi realizada a nossa pesquisa empírica em sala de aula. Quanto à questão do gênero, havia, por exemplo, uma proporção um pouco maior de homens $(55,4 \%)$ do que de mulheres $(44,6 \%)$. O quanto isso 
indica a dificuldade das mulheres, frente à sociedade, em retornar aos estudos, é algo que somente podemos supor.

Quanto à faixa etária, confirma-se a grande presença de adolescentes e jovens na EJA, tendência observada nos últimos anos. Em 2015 no CIEJA Butantã a proporção de alunos se apresentava da seguinte forma: $26,6 \%$ até 17 anos; $14,4 \%$ dos 18 aos 25 anos; $13,5 \%$ dos 26 aos 35 anos; $23,5 \%$ dos 36 aos 45 anos; $17.8 \%$ dos 46 aos 59 anos; e $4,1 \%$ com mais de 60 anos.

O arranjo familiar também interfere no desenvolvimento do aluno e constantemente é incompreendido pelas escolas. No caso em questão, 33,5\% moram com o cônjuge; $27,5 \%$ vivem com o pai ou a mãe; $25,8 \%$ vivem com outros familiares; $11,5 \%$ vivem com "outros" (ou seja, nenhuma das alternativas) e 1,4\% em abrigos.

Outro conjunto de dados interessante é o da orientação sexual. A esmagadora maioria se declara heterossexual (96,5\%). Entre os homossexuais, os gays são a maioria $(0,6 \%)$, seguidos de lésbicas $(0,3 \%)$ e transexuais $(0,3 \%)$. Não houve declarações de bissexuais $(0 \%)$, mas uma parcela significativa respondeu à pergunta com um genérico "outros" $(2,1 \%)$, não se declarando heterossexuais, mas também não se identificando com as demais alternativas.

A composição étnica e racial também merece destaque: $52,9 \%$ se declaram "pardos"; $29,9 \%$, brancos; $14,3 \%$, negros; $1,5 \%$ amarelos; $1,2 \%$, índios. Embora "pardo" seja uma terminologia oficial, é amplamente questionada por setores dos movimentos negros ${ }^{2}$, por na verdade ocultar ou deseducar uma população mestiça que na realidade seria negra. Se somarmos os "pardos" e os "negros", concluiremos que a maioria dos alunos é

\footnotetext{
2 "Como também, como já afirmamos e iremos desenvolver mais um pouco abaixo, não classificamos quem é negro ou negra pelo tom de suas peles. Miscigenados ou não, declarando-se 'pretos' ou 'pardos', para nós são negros e negras todos aqueles e aquelas que têm uma relação de pertencimento e ancestralidade com a África." (Silva, 2016, p. 160).
} 
afrodescendente. Se somarmos ainda esses aos que se declaram "amarelos" ou "índios", os "não brancos" constituiriam a imensa maioria dos alunos.

Os alunos em sua maioria residem no município de São Paulo (87\%). Em segundo lugar está Taboão da Serra, que é habitada por $6 \%$ dos alunos, seguida de Osasco $(3 \%)$, Cotia $(2 \%)$ e "outros" $(2 \%)$. Dos que vivem na cidade de São Paulo, grande parte mora próximo, mas não nas imediações da escola. A distribuição entre os bairros se deu no ano de 2015 da seguinte forma: 34\% viviam no Butantã; $26 \%$ em "outros"; $16 \%$ no Jardim Jaqueline; $8 \%$ no Rio Pequeno; 7\% no Jardim João XXIII; 5\% no Jardim Bonfiglioli e 4\% no Jardim Dracena.

A maioria dos alunos é migrante, vinda de outras regiões do Brasil. A maior parte é do Nordeste (44,5\%). Uma parte considerável, porém, nasceu aqui $(43,2 \%)$. Do Sul vieram 3\%, do Centro-oeste 1,2\% e do Norte $0,9 \%$. Há também alguns imigrantes, que compõem 2,1\% do corpo discente.

Também são muito interessantes os dados sobre o trabalho. Do total de alunos, $59 \%$ afirmavam estar trabalhando, contra $41 \%$ que declararam estar desempregados - sem dúvida uma quantidade impressionante. Dos que trabalhavam, os registrados em carteira eram $52 \%$. Aqueles que provavelmente estavam no mercado informal eram $26 \%$, e $22 \%$ declararam "outros".

As ocupações profissionais são variadas e, em geral, pouco remuneradas. A maioria dos que trabalhavam declarou estar na área de "serviços domésticos" (21\%). Em seguida, temos "comércio" (18\%); "serviços" (17\%); "outros" (16\%); "autônomo/empresário" (8\%); “indústria” (6\%); "construção" (5\%); "aposentado" $3 \%$.

Os alunos da EJA em geral seguem as características da população brasileira quanto à cultura religiosa. Grande parte se declarou católica (49\%), seguida de evangélicos/pentecostais (21\%), "outros" (14\%), "sem religião" $(11 \%)$, ateus $(2 \%)$, espiritismo $(2 \%)$ e candomblé/umbanda (1\%). Como se percebe, os alunos se identificam com diferentes denominações religiosas, mas 
as denominações cristãs são a imensa maioria das respostas. É possível também que a incidência de religiões não cristãs seja um pouco maior do que se mostra aqui, pois ainda permanece o constrangimento de se identificar publicamente com religiões como o candomblé.

No Projeto Político Pedagógico, foi perguntado também sobre a ocupação no tempo livre. A maioria afirmou assistir televisão (28\%), seguido de "internet" (16\%); "espaços familiares e religiosos" (16\%); "atividades físicas" (11\%); "shopping" (7\%); "cinema e espaços culturais" (6\%); "leitura" (5\%) e "parque" (5\%). Embora haja certa variedade nas respostas, a televisão, a internet e o convívio familiar ocupam grande parte do tempo livre dos alunos.

A escola também perguntou sobre as razões que levaram os alunos da EJA a pararem anteriormente os estudos. Muitas foram as causas, mas a mais citada foi a "necessidade de trabalhar" (33\%). Há também respostas como "não gostava de estudar" (11\%); "casamento ou maternidade" (10\%); "falta de tempo e dinheiro" (10\%); "problemas na escola" (9\%); "repeti muitas vezes" $(9 \%)$; "outros" (7\%); "porque a família não deixou" (6\%); "viagem" (3\%); "doença na família" (2\%). Percebemos aqui problemas objetivos, em geral relacionados à classe social de origem dos alunos, como problemas relacionados ao mundo do trabalho. Entretanto, há também impeditivos relacionados a situações de machismo, como as alunas que pararam de trabalhar devido ao matrimônio, ou questões com o próprio sistema educacional, no caso dos que repetiram diversas vezes ou os que afirmavam simplesmente não gostar de estudar.

A partir daí perguntou-se também a razão do retorno aos estudos. As respostas foram as seguintes, da maior para a menor incidência: "recuperar o tempo perdido" (31\%); "para conseguir um trabalho melhor" (22\%); "para continuar os estudos" (11\%); "melhorar a leitura e escrita" (10\%); "imposição dos pais" (7\%); "porque gosta de estudar" (4\%); "para obter benefícios sociais" (4\%); "para cumprir medidas socioeducativas" (4\%); "outros" (3\%); "preencher o tempo livre" (2\%); "elevar a autoestima" (1\%); "ajudar os filhos na escola" $(1 \%)$. Interessante notar que a necessidade do trabalho é citada tanto nas razões do 
abandono quanto do retorno aos estudos. Os alunos aparentemente retornam aos estudos tanto por questões financeiras quanto por outros motivos.

\subsubsection{As instalações e o espaço físico da escola}

A Unidade de Ensino (UE) está localizada próxima a estradas e avenidas cujo fluxo é intenso e se dá no sentido bairro-centro, como a Avenida Eliseu de Almeida e a Rodovia Raposo Tavares, na Zona Oeste de São Paulo. As imediações onde a escola está localizada são habitadas por moradores com razoável perfil socioeconômico, o que pode ser observado pela quantidade de sobrados e casas de médio porte, possivelmente pertencentes aos próprios moradores. Embora a escola seja de fácil acesso, pela quantidade de ônibus e lotações que circulam no entorno, a grande maioria dos alunos necessita de transporte público para chegar, diferente da maioria das escolas públicas municipais, particularmente na EJA, em que grande parte dos alunos reside nas imediações da unidade escolar e chega a pé.

O espaço físico do CIEJA claramente não foi pensado para ser uma unidade escolar, mas uma residência. É uma casa térrea e organizada. Os cômodos da casa se transformaram em salas de aula ambiente, ou seja, não são os professores que se deslocam para a sala onde a turma estuda, mas sim os alunos que se dirigem à sala onde o professor trabalhará. No caso em questão (aulas de História), a sala era bastante desconfortável e apertada para os alunos, que nunca é demais lembrar, eram adultos e jovens com estatura razoável. O mesmo ocorria na outra sala ambiente que funcionava concomitante às aulas de História, que era a sala onde ficava a professora de Geografia. Os corredores são apertados (pois são residenciais) dificultando muito o deslocamento dos alunos antes e depois das aulas, nos intervalos. Particularmente os deficientes (alguns cadeirantes) tinham dificuldade de locomoção. Um bonito, colorido, e pequeno pátio recebia os alunos no intervalo. Esse pátio aparentemente era o quintal do imóvel, e embora bem cuidado, se tornava pequeno nos intervalos diante da quantidade de alunos. 
Grande parte dele também não era coberta, e, quando chovia, a lotação aumentava ainda mais, pois os alunos tinham que se concentrar na pequena parte coberta. $\mathrm{Na}$ escola não há quadra ou qualquer espaço adequado para atividades físicas. Por outro lado, a escola é bastante iluminada, fresca e limpa, propiciando um ambiente relativamente agradável para as aulas.

A rua onde se encontra o portão principal da escola é ao lado da Rodovia Raposo Tavares, onde o trânsito é quase sempre intenso, causando um ruído constante nas imediações da escola. Há pontos de ônibus e uma passarela próximos à escola, o que facilita em parte a chegada dos alunos. Uma parte chega à escola de moto, estacionando na entrada da secretaria. Dois ou três comerciantes estão constantemente vendendo alimentos para os alunos, que se concentram nessas barracas. Particularmente os jovens se agrupam em rodas de conversa, ocasionando atrasos nas aulas. Motoristas e suas peruas normalmente esperam os alunos deficientes ao longo do período de aulas. Há relatos de assaltos na frente da escola no período noturno.

\subsubsection{O contato com a escola}

O primeiro contato com a escola ocorreu no fim de 2014, por intermédio da coordenadora pedagógica. Apresentei-me para a gestão escolar (diretora, assistentes de direção e coordenadores pedagógicos) como professor da rede púbica municipal e aluno de mestrado pela Faculdade de Educação da Universidade de São Paulo. A equipe gestora prontamente me recebeu muito bem e se colocou à disposição para, a princípio, conhecer o projeto de pesquisa.

No início de 2015, foram marcadas as primeiras reuniões com a gestão escolar, para a apresentação da pesquisa. Foi discutida a necessidade que há na pesquisa acadêmica em se aprofundar o cotidiano da Educação de Jovens e Adultos, particularmente nas aulas de História. Foi explicitado que a discussão partiria da Teoria Histórico-Cultural, e a pesquisa empírica consistia 
em uma investigação etnográfica das práticas sócio-discursivas em sala de aula. O projeto foi muito bem recebido, mas no primeiro dia não foi possível conversar com um dos sujeitos principais da pesquisa: o professor. No entanto, a gestão da escola foi muito receptiva à proposta da pesquisa.

A partir da segunda reunião, o professor de História foi apresentado à proposta. Novamente, todos se mostraram muito solícitos. O professor de História foi simpático e se prontificou a escutar a proposta da pesquisa. O fato de o pesquisador ser também professor da rede pública talvez tenha contribuído para uma certa "camaradagem" nos trabalhos. Ele relatou que as turmas seriam relativamente tranquilas, sem grandes problemas disciplinares, e que eventualmente se ausentaria por alguns trabalhos externos à escola. Relatou também estar próximo de se aposentar, e estar já nos últimos anos de carreira docente. A única ressalva do professor foi o pedido de não filmar e apenas gravar em áudio as aulas. Fez questão também de consultar os alunos para a concordância desses procedimentos, o que foi prontamente atendido de nossa parte. Tanto a gestão, quanto o professor demonstraram boa vontade em colaborar com a pesquisa, e frisaram que estavam acostumados a receber pesquisadores na escola.

Entre o fim de 2014 e o primeiro semestre de 2017, estivemos em contato constante com a escola, conversando e observando seu cotidiano e os sujeitos que dela faziam parte. Para a pesquisa empírica em sala, privilegiamos o primeiro semestre de 2015, quando acompanhamos o módulo de aulas de História por aproximadamente dois meses e meio.

\subsubsection{As aulas de História no CIEJA}

Como dito anteriormente, as aulas são oferecidas em módulos. O aluno permanece pouco mais de um mês estudando apenas duas matérias do currículo regular. Não são utilizados livros didáticos especiais para a EJA (ao menos nas aulas de História) e as salas-ambiente contam com recursos 
importantes, mas comuns, como mapas, equipamento para filmes e eventualmente, textos a serem analisados. Às sextas, há uma programação alternativa, oferecida pelos próprios docentes, com cursos variados.

Ao longo das semanas, algumas vezes os alunos foram levados para saídas e projetos externos, como exibições de filmes no CEU Butantã. Normalmente esses convites vinham da Diretoria Regional de Ensino e não faziam parte de um projeto interno da escola. Por razões burocráticas, o transporte escolar dos alunos deficientes os leva apenas da sua residência para a escola, e eles dificilmente participavam dessas saídas culturais.

Os professores são profissionais da rede pública municipal, designados para esse cargo no CIEJA. Além de trabalhar na sala de aula, têm horários individuais e coletivos, que possibilitam a preparação de aulas e a construção de projetos pedagógicos que sejam planejados por todo o corpo docente. A relação entre os profissionais (gestores, professores, quadro de apoio) e os alunos é acolhedora e cordial, sinalizando uma empatia perceptível nas relações. A recepção da presente proposta de pesquisa foi muito positiva também.

A turma acompanhada na pesquisa contava com dez ou doze alunos, dependendo do dia. A proporção de homens e mulheres variava a cada dia, mas tendia a ser metade para cada gênero. O mesmo ocorria com as diferentes gerações: apesar da constante oscilação, quase sempre havia uma quantidade semelhante de jovens adolescentes e de adultos, destacando-se Z, uma aluna idosa. A quantidade de brancos presentes nas aulas era aparentemente maior do que a de negros; pelas suas referências culturais (o que narravam ao longo das aulas, suas memórias, o sotaque), a maioria é migrante, proveniente das zonas rurais, notadamente do Nordeste. Entre os jovens, havia pelo menos um em condição de Liberdade Assistida pela Justiça. Havia também três alunos jovens portadores de algum tipo de deficiência intelectual (dois homens brancos e uma mulher negra); um acompanhava ativamente as aulas, enquanto os demais eram mais discretos. Entre os adultos, todos relatavam estar trabalhando. Todos esses elementos são 
importantes, pois constituem o lugar a partir do qual as interações e intervenções desses sujeitos ocorrem em sala de aula.

O professor é homem, branco, e comentou nas aulas planejar se aposentar nos anos seguintes. Utiliza prioritariamente o quadro branco como recurso das aulas, fazendo sempre muitas perguntas e suscitando as respostas nos alunos. É respeitoso e, ao mesmo tempo em que explica detalhadamente os temas que traz, sempre abre um generoso espaço para as perguntas e comentários dos alunos.

As aulas observadas ocorreram no período da manhã. A sala é desconfortável e apertada, e a disposição das carteiras é tradicional, ou seja, em fileiras e viradas para frente. A interação entre esses sujeitos variava entre a solidariedade nas tarefas escolares e o conflito gerado por diferentes interesses, sobretudo em gerações diferentes.

A entrada dos alunos era às sete da manhã, mas a aula efetivamente começava poucos minutos depois. Ao chegar, os alunos recebiam na recepção um modestíssimo lanche (em geral, um pacote com poucas unidades de bolachas ou um pedaço de bolo, e um suco). Aos poucos os alunos se sentam na apertada sala, aguardando o professor. Alguns alunos adultos como C e Z sempre estão entre os primeiros. Outros, mais adolescentes como San, entre os atrasados.

Os alunos chegam e em geral são cordiais uns com os outros, recebendo o pesquisador muito bem também. Conversam na sala logo de manhã sobre as aulas, os professores, o trabalho, e outros assuntos. $O$ professor chega poucos minutos depois, com uma pequena pasta contendo a ficha dos alunos. Ele faz a chamada e marca nessa ficha individual a presença ou ausência dos estudantes. Enquanto isso, alguns atrasados ainda se acomodam na sala, que por ser pequena, fica bastante cheia. Quando todos estão na sala, não é possível transitar com conforto entre as carteiras. Os alunos que, durante a aula, tem de ir ao banheiro, são obrigados a esbarrar nos colegas. 
Ao terminar a chamada, em geral o professor se levanta, retoma o que tem sido discutido nas últimas aulas e faz anotações no quadro branco. As anotações costumam ser bem diretas e sucintas, tentando demonstrar clareza e uma certa precisão conceitual. Quando começa a explicar, o professor tende a divagar um pouco mais, recorrendo a exemplos, chamando os alunos a um esforço de imaginação de se colocarem em determinado período histórico ou pensarem sobre determinados temas da História (mineração, colonização, bandeirantismo, cultura indígena, escravidão, independência do Brasil, etc.).

Os recursos utilizados são bastante modestos. Eventualmente há pequenos textos xerocados em preto e branco e filmes. A explicação oral é a prática mais utilizada nessas aulas. Nas aulas observadas, praticamente não houve análise de fontes históricas ou contraponto de diferentes versões historiográficas.

Os alunos anotam atentamente o que é escrito no quadro branco, e parecem prestar atenção ao que é dito. Alguns cedem à sonolência do período matutino. Parte dos adolescentes se ocupa bastante com o celular e é mais agitada. Conversam mais entre si do que os adultos, durante a explicação do professor. Não houve discussões ou brigas nas aulas observadas.

A participação nos debates não é uniforme entre todos os alunos, como era de se esperar. Há dois alunos que constantemente se colocam: curiosamente a aluna mais velha $(Z)$ e um dos adolescentes (San). Há outros que participam eventualmente com seus comentários, e finalmente uma parte que não faz comentário algum, particularmente os alunos deficientes.

A diferença de postura entre adultos e adolescentes é notória. Os primeiros são mais atentos e "disciplinados", ou seja, sentam-se por um longo período, conversam menos durante as explicações, se esforçam mais para realizar atividades, não se distraem com o celular. Ao se dirigirem ao professor, sua fala é sempre educada e polida. Os adolescentes em geral conversam um pouco mais, a ponto de o professor ter de chamar a atenção algumas vezes. 
Alguns chegam atrasados, pedem para ir ao banheiro com mais frequência, ficam um tempo maior olhando o celular.

Parte dos adultos demonstra não gostar da postura dos adolescentes. São relativamente comuns os comentários em sala do tipo: "para de brincar!", "agora é sério", "ai, meu deus". Parte dos mais velhos se incomoda com os adolescentes e chama a sua atenção durante as aulas. Os adolescentes por vezes fazem também comentários reprovando o olhar dos adultos. Isso porque os adultos aparentemente têm alguma dificuldade com determinados procedimentos escolares, que os adolescente eventualmente se apropriaram de maneira mais eficaz. Quando criticados pelos primeiros, chegam a dizer: "então faz melhor". Os jovens também fazem comentários jocosos sobre a aparência física das mulheres (cabelo, roupas, etc.), causando desconforto na sala.

Apesar da aparente diferença de postura entre os dois grupos, não é possível dizer se os adultos - mais disciplinados - necessariamente aprendem mais que os adolescentes. San, que é o mais agitado, responde e participa oralmente das aulas mais do que a maioria dos adultos.

As aulas duram duas horas e meia. O professor parece dividir o tempo entre uma primeira metade da aula mais teórica, privilegiando sua explicação, com eventuais comentários dos alunos. $\mathrm{Na}$ segunda metade da aula, são passadas algumas questões sobre o que acabou de ser comentado. Às vezes há um texto em que os alunos podem se basear para responder as questões, às vezes não, tendo que recorrer à memória do que acabou der ser explicado.

As perguntas escritas em geral são simples, mas grande parte dos alunos demonstra grande dificuldade em respondê-las. Nesse momento, a sala fica concentrada nos exercícios, e é comum que os alunos se ajudem e tirem dúvidas com o professor. Esse, por outro lado, auxilia com perguntas, mas costuma dizer que "agora eu esqueci tudo que eu expliquei", forçando os alunos a pensar por si próprios nas respostas das questões. 
No fim da aula, o professor corrige as questões com os alunos, que fazem questão de ler suas respostas. Demonstram ter participado bem da discussão, mas ainda tem certa dificuldade em responder questões mais conceituais de maneira escrita. Interessante a disposição com que leem suas respostas, parecendo querer averiguar seus conhecimentos perante 0 professor. 


\section{Teoria Histórico-Cultural e EJA}

A escolarização é reconhecida como um processo que traz muitas transformações para os sujeitos que dela participam. No entanto, projetada para crianças e jovens, em muitas sociedades a escolarização jamais alcançou toda a população adulta, ou o fez de maneira insuficiente, excluindo enorme parcela da população de uma experiência escolar que responda às suas necessidades e Ihes possibilite uma apropriação significativa de determinados conhecimento sistematizados.

Jovens e adultos não escolarizados possuem uma experiência que os diferencia sobremaneira das crianças em idade escolar. Normalmente possuem profunda relação com o mundo do trabalho, notadamente em uma sociedade de classes com grandes contradições. Habitam territórios urbanos com oferta questionável de serviços públicos, e costumam participar de diversas manifestações culturais, particularmente nas periferias das grandes cidades.

Assim, são alunos que foram historicamente privados das formas de conhecimento sistematizado próprias da escola, mas ao mesmo tempo possuem muitos conhecimentos constituídos a partir da própria sociedade e do cotidiano em que vivem. Nesse sentido, nos interessa investigar quais as contribuições que o pensamento de Vigotski e de outros autores da perspectiva Histórico-Cultural teriam para a compreensão do possível impacto da escolarização para esses alunos.

\subsection{O trabalho precursor de Vigotski e Luria}

Imediatamente após a Revolução de Outubro de 1917, a União Soviética atravessou um período de efervescência cultural. Apesar da saída de alguns intelectuais e funcionários do Estado Czarista, particularmente com a Guerra Civil, outros tantos ficaram e deram intensa contribuição à construção de uma "nova sociedade", segundo os ideais comunistas de Lênin e dos bolcheviques. A partir de meados da década de 1920, o fechamento do regime e o advento 
da ditadura stalinista restringiu muitas dessas conquistas. Mesmo assim, produções acadêmicas como as de Vigotski e Luria (1902-1977) sobre os processos mentais de populações não escolarizadas em algumas regiões da URSS foram precursoras.

Segundo Luria,

\begin{abstract}
A tese marxista-leninista segundo a qual todas as atividades cognitivas humanas fundamentais tomam forma na matriz da história social, produzindo assim o desenvolvimento sóciohistórico, foi aprofundada por L. S. Vygotsky de modo a servir como base de grande parte da pesquisa soviética em psicologia (LURIA, 1990, p. 7).
\end{abstract}

A partir desses princípios, Luria e Vigotski empreenderam um projeto que se esforçava por pesquisar o desenvolvimento cognitivo de adultos nas regiões do Uzbequistão e Kirghizia. Para Luria, essas populações viviam em uma condição materialmente empobrecida e com alto índice de analfabetismo antes da Revolução de 1917. A partir da década de 1920, amplas regiões do campo na URSS passaram por um processo de reforma agrária que consistia em uma coletivização das terras, provocando mudanças no modo de vida dessas populações, algumas de cultura islâmica. A fim de estudar o impacto dessas transformações no desenvolvimento cognitivo dessas populações, os dois pesquisadores se lançaram o desafio de pesquisar as transformações no pensamento de adultos não ou pouco escolarizados, em um contexto também de esforço da expansão da educação pública. Chama atenção a pesquisa em indivíduos adultos, diferente de grande parte das pesquisas da época que privilegiava o estudo sobre crianças. O estudo foi feito entre 1930 e 1932.

Vigotski, já doente e em seus últimos meses de vida, deu contribuições à distância, a partir dos dados que recebeu da pesquisa. Luria foi a campo duas vezes; os resultados das pesquisas foram questionados na URSS, seja porque na década de 1930 a ditadura de Stalin interpretava as ponderações sobre o desenvolvimento cognitivo da população adulta daquelas regiões como críticas 
à política de coletivização da agricultura (ALVAREZ, A.; RIO, P. del, In: VYGOTSKY, 1997), seja porque, como a Rússia tinha uma tradição de opressão sobre as minorias étnicas e religiosas da região desde os tempos do czarismo, o trabalho poderia ser lido como desrespeitoso em relação àqueles povos. De fato, Luria responsabilizou de maneira um tanto equivocada a religião islâmica por um certo "atraso" cultural da população do Uzbequistão (COLE, In: LURIA, 1990, p. 14).

No entanto, Luria partia da premissa vigotskiana de que os processos mentais estão intimamente relacionados com os processos de transformações históricos e com a cultura (particularmente considerando o papel dos instrumentos e dos signos). Para ele, os processos mentais e a consciência se constituiriam nas atividades historicamente constituídas pelo homem no plano social. Criticou estudos que buscavam caracterizar as diferenças cognitivas entre os povos, particularmente os não ocidentais, como inatas biológica ou espiritualmente, ou ainda como resultado de uma inferioridade de certas raças em relação aos povos brancos ocidentais.

Entusiasta da Revolução de Outubro, Luria descreve o contexto do Uzbequistão e a justificativa para a pesquisa. Para ele, a região era uma sociedade tradicional feudal e islamizada, passando por um amplo processo de modernização após a Revolução, que envolveu a industrialização, ampliação da escolarização e a coletivização dos campos. A hipótese de pesquisa era que adultos que estivessem mais ligados a atividades tradicionais apresentariam determinados procedimentos mentais na resolução de questões e problemas apresentados, enquanto os indivíduos que estivessem já envolvidos com atividades mais "modernas", particularmente tendo sido escolarizados nos últimos anos, apresentariam outra forma de pensamento, mais abstrato e conceitual.

Para Luria, as crianças em idade pré-escolar (ou nos anos iniciais da escola) tenderiam a ter um pensamento "gráfico" ou "concreto", ou seja, baseado nas experiências sensoriais, classificando objetos de acordo com suas características físicas. Após alguns anos na escola, particularmente na 
adolescência, as palavras deixariam de nomear séries categoriais para ser parte de um sistema semântico, histórica e socialmente constituído, e passariam a orientar o pensamento. Assim, o sujeito passaria a pensar não com base em sua vivência imediata, mas a partir da linguagem, como instrumento de abstração e generalização, o que caracterizaria o chamado "pensamento taxonômico conceitual". A escolarização teria um papel importantíssimo nisso, pois resultaria na formação de um pensamento de tipo "científico".

Interessava a Luria saber o quanto essas conclusões se aplicavam, ou não, a adultos pouco ou não escolarizados. Para isso, realizou diversos experimentos, cuidadosamente mediados por boas relações com a população do Uzbequistão, muitas vezes aplicados como se fossem "jogos", em ambientes informais como casas de chá. Alguns desses experimentos consistiam, por exemplo, em oferecer imagens de quatro objetos que dialogassem com as vivências dos entrevistados; três deles poderiam ser agrupadas em um conceito e uma não, de acordo com generalizações abstratas ("mamíferos" ou "ferramentas", por exemplo) ou usos cotidianos ("animais da fazenda" ou "carpintaria", entre outros), a depender do que o participante do experimento achasse mais coerente, de acordo com seu pensamento. Os sujeitos eram adultos entre 18 e 65 anos; alguns trabalhavam sozinhos em suas terras, outros nas fazendas coletivizadas. A maioria era analfabeta, mas alguns deles já estavam há poucos anos na escola.

Os resultados descritos por Luria atestam para ele o impacto da escolaridade sobre indivíduos adultos. A grande maioria dos entrevistados agrupava as imagens de objetos de acordo com o seu uso cotidiano. Alguns sujeitos que haviam recentemente passado por escolas ou cursos técnicos conseguiam utilizar as duas formas de classificação de objetos (situacional/cotidiana e generalizante), embora o uso cotidiano predominasse. Um terceiro grupo, notadamente mais jovem e um pouco mais escolarizado, primava pela classificação categorial (LURIA, 1990). Para Luria, 
A maior parte dos sujeitos classificou os objetos não de acordo com princípios verbais e lógicos, mas de acordo com esquemas práticos. Entretanto, esse pensamento concreto não é inato, nem geneticamente determinado. Resulta do analfabetismo e dos tipos rudimentares de atividade predominantes na experiência cotidiana desses sujeitos. Quando muda o padrão de vida e se ampliam as dimensões da própria experiência, quando eles aprendem a ler e a escrever, a ser parte de uma cultura mais avançada, esta maior complexidade de sua atividade estimula novas ideias (LURIA, 1990, p. 106-107).

Assim, o autor considera que indivíduos não escolarizados seriam, de alguma maneira, deficitários em seu desenvolvimento cognitivo. Por outro lado, pondera sobre os métodos que utilizou, pois a maioria dos participantes não falava russo, sendo os diálogos dos experimentos traduzidos por intérpretes locais; o autor levanta a hipótese de que talvez eles não tenham compreendido totalmente as perguntas feitas.

Consideramos aqui outra possibilidade, pouco explorada por Luria nessa pesquisa, que consiste em que os sujeitos analfabetos na verdade estariam utilizando o que Vigotski chamava de "conceitos espontâneos" ou "cotidianos" nas suas respostas; dessa maneira, respostas que para os participantes tinham sua lógica atribuída ao uso cotidiano dos conceitos foram consideradas por Luria como culturalmente pouco desenvolvidas, por não corresponderem ao que se considerava um pensamento "científico".

Em todo o caso, a sua pesquisa teria atestado, segundo o autor, que transformações sócio-históricas profundas acarretam em alterações também no desenvolvimento cognitivo dos sujeitos envolvidos, particularmente com a introdução de novas atividades no cotidiano dos povos estudados e a expansão da educação pública.

Para Cole (1990), há uma imensa contribuição do trabalho de Luria, praticamente pioneiro em pesquisar os processos cognitivos de adultos de sociedades tradicionais. Mesmo assim, faz uma importante ressalva: para ele, o que Luria identifica como novas formas de pensamento (menos "concretas" e 
"gráficas", e mais "taxonômicas" e "abstratas"), advindas de uma mudança estrutural da sociedade após a Revolução Russa de 1917, na verdade seriam “(...) mudanças na aplicação de modos previamente disponíveis aos problemas particulares e contextos do discurso representados pela situação experimental" (COLE, in: LURIA, 1990, p. 16).

A questão do impacto da escolarização sobre o desenvolvimento dos indivíduos já foi alvo de importantes pesquisas. Para Cole, as contribuições da Teoria Histórico-Cultural

[...] fornecem um ponto de partida para considerar as características especiais da escolarização formal como um contexto de atividade no qual alguns seres humanos, em certas circunstâncias culturais e em certas eras históricas, se desenvolvem (COLE, in: MOLL, 1996, p. 87).

Assim, para esse autor, o problema da escolarização poderia ser pensado da seguinte maneira: teria a escola, como uma instituição historicamente constituída, impacto nos indivíduos, a ponto de podermos afirmar que o desenvolvimento de sujeitos escolarizados é distinto daqueles não escolarizados? Algumas das impressões de Luria dão conta de que sujeitos não escolarizados tenderiam a pensar muito mais a partir das suas experiências imediatas, enquanto sujeitos um pouco mais escolarizados responderiam os testes a partir dos termos lógicos dos problemas. Porém, para Cole (1990), Luria não foi totalmente coerente com a teoria vigotskiana, ao não considerar as atividades principais da cultura do povo do Uzbequistão como constitutiva dos processos cognitivos daqueles indivíduos, propondo-lhes testes que derivavam de sistemas característicos da Europa Ocidental. $\mathrm{Na}$ medida em que aplicava testes que requeriam habilidades ensinadas na escola formal em uma população ainda pouco escolarizada, os resultados não poderiam deixar de demonstrar uma inabilidade dos indivíduos com as perguntas feitas nos testes. 
Segundo Cole (1996), as perguntas deveriam ter levado em conta as principais atividades dos indivíduos, aquelas que constituíam o seu desenvolvimento cognitivo, a fim de melhor compreendê-lo. Dito de outra maneira, deveríamos hoje nos preocupar menos por que indivíduos pertencentes a culturas tradicionais não pensam da mesma maneira que povos ocidentais, mas sim investigar sobre o funcionamento próprio da mente a partir da atividade como princípio investigativo.

O trabalho de Michael Cole e Silvia Scribner com o povo Vai, da Libéria, nos anos 1970, foi muito importante nesse sentido. Os Vai são um povo tradicional que possui um sistema de leitura e escrita diferente do ocidental. Dessa maneira, os pesquisadores se questionavam se a aquisição da leitura e escrita por si só é capaz de constituir pensamento científico nos sujeitos, o que não se confirmou. A conclusão foi que apenas a alfabetização não garante 0 pensamento sistematizado, e sim a participação em práticas sociais que propiciem instrumentos semióticos que possibilitem a formação de pensamento conceitual científico, particularmente as existentes nas sociedades modernas e industriais (BARRO; BASTOS, 2015), entre as quais a escola seria uma delas.

Peeter Tulviste (1945-2017), discípulo de Luria, buscou compreender que mudanças a escolaridade traz para o pensamento de sujeitos de culturas tradicionais $^{3}$. Para ele, se, de acordo com Vigotski, é o surgimento da escola, como instituição historicamente constituída, que marca o surgimento do pensamento por conceitos científicos, então o questionamento a respeito das diferenças qualitativas de pensamento de sujeitos escolarizados e não escolarizados deve se debruçar sobre as mudanças cognitivas de adultos que

\footnotetext{
3"Culturas ou grupos culturais são designados como tradicionais se não há um tipo "moderno" de atividade econômica, ciência, escolarização ou literatura. Eles se distinguem por uma ligação à tradição, distinta daquelas culturas e grupos caracterizados por constantes mudanças socioculturais. Em outros tempos, essas culturas e grupos eram frequentemente chamados "primitivos", mas esse termo implica um desagradável e injustificado aspecto de julgamento. $\mathrm{Na}$ literatura etnográfica, o termo "arcaico" é utilizado, com várias reservas, para essas culturas. A fim de evitar tais dificuldades como, por exemplo, a necessidade de distinguir, em casos específicos entre sociedades arcaicas e feudais, nós ficaremos com o termo "culturas tradicionais" que, do ponto de vista dos propósitos perseguidos nos estudos comparativos do pensamento, é bastante adequado." (TULVISTE, 1991, p. 7-8, tradução nossa).
} 
recentemente passaram por esse processo. Segundo o autor, o estudo de Luria na década de 1930 não tinha como objetivo se aprofundar no pensamento de indivíduos pertencentes a culturas tradicionais a partir de suas atividades, e sim detectar e explicar as mudanças psicológicas pelas quais passam os sujeitos a partir de mudanças socioeconômicas. Tulviste (1991) quis seguir com a compreensão desse fenômeno em movimento, ou seja, compreender as transformações pelas quais passam sujeitos adultos de culturas tradicionais que se deparam pela primeira vez com o pensamento conceitual sistematizado a partir da escolarização.

Para Tulviste, o primeiro estudo comparativo de formas de pensar em diferentes culturas foi o de Luria, com a colaboração de Vigotski. A essa pesquisa, seguiram-se outros estudos, particularmente os de Cole e Scribner na década de 1970 que já mencionamos aqui. Tanto as pesquisas de Luria no Uzbequistão quanto as de Cole na Libéria mostram uma interessante semelhança nas respostas de indivíduos não escolarizados a perguntas similares, demonstrando que, apesar das diferenças culturais, sujeitos advindos de culturas tradicionais (não escolarizadas, não industrializadas, pouco urbanizadas) tendem a operações mentais baseadas na sua experiência cotidiana e não em generalizações. Não se pode considerar esses sujeitos como portadores de baixas habilidades mentais; na verdade tentam resolver os problemas apresentados nos experimentos com operações diferentes das usuais em sociedades escolarizadas. As questões eram evidentemente estranhas aos sujeitos, especialmente na forma em que eram feitas. A questão, então, é por que esse tipo de teste é estranho a sujeitos não escolarizados, bastando dois ou três anos de escolaridade, segundo Luria, para que os resultados melhorem significativamente (TULVISTE, 1991).

Quando se realizam testes silogísticos em sujeitos não escolarizados, parte-se da premissa de que a pesquisa visa verificar se esses indivíduos serão capazes de responder tais perguntas. Na verdade, a própria proposição das perguntas deveria ser objeto de estudo, já que, ao fazê-las, os autores acima já partiam do pressuposto de que havia operações mentais diferentes de 
acordo com o nível de escolaridade dos sujeitos. A questão é por que e como o pensamento passa de orientado pelas experiências individuais e cotidianas para mediado por generalizações e abstrações a partir da escolarização. Para Tulviste,

No seu folclore e crenças, pessoas pertencentes a culturas tradicionais constantemente vão além dos limites da "experiência prática imediata", apesar de não o fazerem resolvendo problemas silogísticos em situações experimentais (TULVISTE, 1991, p. 121, tradução nossa).

Dessa maneira, não se pode afirmar que o pensamento de indivíduos pertencentes a culturas tradicionais é exclusivamente empírico e concreto. $\mathrm{O}$ que parece haver, para o autor, é a relação de suas atividades com as experiências cotidianas (sejam sensoriais com o mundo físico, sejam religiosas/espirituais com a sua cultura). A questão é que não haveria uma grande demanda por operações mentais fora dessas práticas sociais. Nas sociedades industrializadas, ao contrário, seriam constantemente demandadas operações mentais que extrapolam o cotidiano do sujeito, que, com certa frequência, tem que lidar com problemas com os quais ele nunca se deparou concretamente. Assim, expor problemas silogísticos típicos do pensamento escolarizado ou científico a indivíduos não escolarizados não prova nada a não ser que eles não conseguem responder a essas questões, que, na verdade, não são universais, mas específicas de uma cultura que lhes é estranha.

O que Tulviste (1991) aponta é que, no processo de escolarização, não é possível demonstrar ou reproduzir todo o processo de produção de conhecimento científico acumulado pela humanidade para os alunos. Para explicar uma determinada teoria sobre um objeto do conhecimento, é necessário recorrer a uma linguagem científica e a diversos sistemas de conceitos. A escolarização exige, portanto, a construção científica de objetos "ideais" e a relação entre eles. Assim, enquanto indivíduos provenientes de sociedades tradicionais tendem a pensar a partir da sua experiência social, 
indivíduos escolarizados aprendem a pensar problemas não relacionados diretamente às suas práticas sociais cotidianas com operações mentais que não representam realidade concreta alguma para eles. É ensinado um método de pensamento no qual as respostas são mais ou menos "independentes" da situação cotidiana. A diferença entre os dois grupos (escolarizados e não escolarizados) reside não tanto em um suposto grau de complexidade das operações cognitivas, mas sim no método em encontrar as respostas. Não se trata de identificar se o nível do funcionamento mental dos indivíduos é "baixo" ou "alto", mas a que tipo de atividade e método de pensamento está mais relacionado.

O autor se perguntou se operações mentais provenientes da escolarização, como o pensamento científico, permanecem em adultos que retornam para práticas societárias tradicionais, onde a demanda por essas formas de pensamento é menor. Os resultados demonstraram que quando o sujeito conclui ou abandona a escola e se dedica a atividades tradicionais que não requerem um tipo de pensamento mais científico, boa parte das respostas que dão nos testes aplicados são "empíricas", baseadas na sua experiência cotidiana atual. Assim, teríamos que reformular a tese de que a escolarização promove formas de pensamento científico, porque a permanência desse tipo de pensamento dependeria de atividades cotidianas que demandassem culturalmente esse tipo de operação (TULVISTE, 1991) ${ }^{4}$.

Por outro lado, há nos silogismos algo que induz a um resultado que cria uma aparente dicotomia entre escolarizados e não escolarizados. Uma das perguntas dos testes que Tulviste aplicou foi: "Asan e Kenesh sempre tomam chá juntos. Asan está agora bebendo chá. Kenesh está bebendo chá ou não?" (TULVISTE, 1991, p. 139-140, tradução nossa). Sujeitos que se baseiam na

\footnotetext{
${ }^{4}$ As pesquisas de Vóvio (1999) que comentaremos mais a seguir parecem confirmar essa hipótese.
} 
sua experiência cotidiana para responder testes sabem que acontecimentos do dia a dia são suscetíveis a diversos tipos de interferências; na verdade a palavra "sempre" pode significar "geralmente". Então para uma certa forma de pensar baseada nas experiências empíricas, apesar de Asan e Kenesh geralmente beberem juntos, não há como garantir, do ponto de vista de sujeitos de sociedades tradicionais, que nesse exato momento ambos estão bebendo juntos, é possível que um outro acontecimento tenha desmarcado eventualmente o encontro deles.

Haveria, assim, pelo menos dois métodos de resolução de problemas encontrados aqui. O primeiro seria o chamado "senso comum", próprio do pensamento do dia a dia, a partir do qual o sujeito solucionaria vários problemas práticos e teóricos. Seu critério seria a "veracidade": o sujeito pensaria na sua vivência para solucionar problemas cotidianos. O segundo, ligado à ciência e à escolarização, seria o pensamento científico; o sujeito pensaria de maneira consciente em primeiro lugar no seu conhecimento, e verificaria as suas conclusões em relação às suas premissas. Essa segunda forma de pensar pode, inclusive, regredir, se subutilizada. Não se trata de uma forma necessariamente mais "avançada" de pensamento, mas uma operação mental utilizada em atividades específicas.

Mesmo nas sociedades industrializadas modernas, o uso dos conceitos científicos é restrito a determinadas situações. Nas culturas tradicionais, a ausência das metodologias de produção de conhecimento científico e da escola - da forma são como concebidas em sociedades industrializadas - pode implicar no não desenvolvimento de pensamento conceitual científico nos sujeitos. Concordando com Vigotski, Luria (1990) se refere à diferença entre conceitos cotidianos e científicos; para Tulviste (1991), os testes aplicados por Luria carregam alguns problemas, entre eles 0 fato de que sujeitos provenientes de sociedades tradicionais raramente são demandados a definirem verbalmente conceitos. Quando tais indivíduos são introduzidos na escola - instituição que demanda definição de conceitos -, então essa operação começa a se tornar mais comum. 
Segundo Tulviste (1991), se para Vigotski, os conceitos científicos apareceriam apenas com a escolarização, para ele seria possível que conceitos sistematizados, com características mais generalizantes e abstratas apareçam em indivíduos não escolarizados, desde que o uso desses conceitos seja familiar. Para o autor, embora Luria tenha concluído que sujeitos escolarizados têm mais facilidade em classificar objetos nas mesmas categorias, Tulviste opina que o uso de palavras na linguagem já constitui uma atividade semiótica de categorização, e que se devidamente explicados 0 contexto e objetivo de questões e testes, sujeitos de sociedades tradicionais conseguiriam classificar objetos que fossem familiares a eles:

Os dados acumulados não deixam dúvida de que pessoas de qualquer grupo cultural, a partir de material experimental apropriado e instruções apropriadas dadas, chegarão a todos os principais tipos de classificação: percepção, funcional e semântica (taxonômica) (TULVISTE, 1991, p. 153, tradução nossa).

Assim, a diferença entre o conceito cotidiano e o científico não seria a classificação em si. Aparentemente, a escolarização leva a uma maior facilidade para a classificação e a linguagem utilizada seria mais sofisticada; no entanto, não seria correto dizer que os sujeitos apenas seriam capazes de classificar objetos sob a forma de conceitos, utilizando-se de palavras, apenas a partir da escolarização. Indivíduos não escolarizados poderiam ser capazes, em alguns casos, de separar o conceito de referente (aquilo a que o conceito se refere), algo que, para Tulviste (1991), Vigotski acha só ser possível no pensamento científico. Assim,

Em alguns experimentos sujeitos de culturas tradicionais exibem características de unidades de pensamento verbal que Vigotski considerava serem características somente de conceitos científicos. Eles distinguem o conceito e o referente de maneira que essa distinção não pode ser considerada exclusivamente característica dos conceitos aplicados na ciência. Sujeitos tradicionais às vezes estabelecem relações 
supraempíricas entre os conceitos (TULVISTE, 1991, p. 157, tradução nossa).

Para o autor, apesar de sociedades não escolarizadas não utilizarem a ciência como é concebida nas sociedades modernas, outras atividades podem demandar pensamento conceitual, sinalizando inclusive elementos de transformação cognitiva (desenvolvimento) nesses adultos. No entanto, a ausência de atividades ligadas diretamente à ciência, às leis e a economias industrializadas é o que explica que operações mentais como o pensamento conceitual sistematizado sejam menos demandadas e utilizadas nos indivíduos dessas sociedades. Isso não quer dizer de maneira alguma nem que indivíduos provenientes de sociedades tradicionais sejam cognitivamente incapazes de pensar em conceitos sistematizados, nem que indivíduos escolarizados necessariamente pensem o tempo todo com grande eficiência por conceitos científicos.

Para Vigotski (2010), a aquisição da linguagem escrita pela escolarização possibilita a formação de pensamento conceitual científico, permitindo, entre outras coisas, que a própria palavra, ao se descolar das situações concretas, possa ser objeto de análise. Passa-se a pensar o conceito em sim. Para Tulviste (1991), embora isso seja verdade, não se pode afirmar que a simples aquisição da escrita ou a passagem pela escolarização garanta a formação do pensamento científico de maneira satisfatória nos sujeitos. Para a formação de pensamento científico, além da escrita em si, é preciso que a cultura demande dos sujeitos pensar sobre o que é escrito e como é escrito. Nem toda escrita é acompanhada de pensamento científico.

Por outro lado, é possível o pensamento conceitual científico sem escrita? Para o autor, a escrita somente auxilia na formação dos conceitos científicos se a escolarização for capaz de introduzir o aluno no conhecimento científico, com os métodos e teorias que lhes são próprios. Dessa maneira, não se pode dizer que a escolarização transforma por completo a cognição dos sujeitos escolarizados, mas, sim, que constitui uma determinada maneira de 
pensar pelos conceitos científicos, que nem sempre é utilizada no cotidiano dos sujeitos, a depender dos problemas que se têm que resolver. Por outro lado, o problema central de Vigotski não seria a comparação direta entre indivíduos não escolarizados e escolarizados, mas as transformações que a escolarização traria para o desenvolvimento dos sujeitos (TULVISTE, 1991).

Outra importante mudança no pensamento demandada pela escolarização é a autoconsciência; ou seja, o sujeito ser consciente do seu próprio pensamento e dos conceitos que instrumentaliza. A escolarização exige esse esforço contínuo, a fim de resolver problemas científicos e verificar a validade do próprio raciocínio, de acordo com regras teóricas que independem da situação imediata. Outra mudança demandada pela escolarização seria a característica da ciência de propor contrapontos entre teorias e pontos de vista diferentes; a autoconsciência do indivíduo seria decorrente desse constante exercício de alteridade com outros pontos de vista a qual seria submetido na escola. Seria necessário pensar se, e em que medida, a escola de fato consegue trazer esse elemento do debate científico para as práticas pedagógicas:

Por um lado, na sua origem, o pensamento de pessoas nas culturas "modernas" parece estar conectado com a ciência em um nível muito maior do que se tem assumido. Por outro lado, na sua natureza, parece ser científico em um nível muito mais baixo do que nós pensamos (TULVISTE, 1991, p. 171, tradução nossa).

Historicamente, considerou-se de maneira "eurocêntrica" que as práticas sociais e, portanto, as operações mentais, dos povos europeus, particularmente após o neocolonialismo do século XIX, eram mais desenvolvidas e sofisticadas que as dos demais povos e culturas do mundo. Em resposta a isso, surgiram também, em meados do século $X X$, correntes de pensamento que afirmavam que as diferenças culturais e psicológicas eram formais, apenas variações de um mesmo funcionamento das operações 
psicológicas dos sujeitos. Mas para Tulviste (1991), as diferenças existem, e devem ser não apenas descritas, mas explicadas a partir de como a história e a cultura constituem o desenvolvimento do pensamento nos indivíduos.

Para o autor, é possível afirmar que, em diferentes culturas, o desenvolvimento do pensamento dos sujeitos é diferente, mas não se pode afirmar que indivíduos pertencentes a culturas tradicionais "pensam como crianças", ou são deficitários. De fato, a Revolução Industrial favoreceu a constituição de novas ferramentas psicológicas como o pensamento por conceitos sistematizados, ligadas às demandas dessa sociedade burocratizada, que só fazem sentido em determinadas condições e para certas demandas particulares. Em todo o caso, apesar dos limites que os comentadores da própria Teoria Histórico-Cultural como Cole e Tulviste colocaram sobre as pesquisas de Luria, em colaboração com Vigotski, elas foram importantíssimas:

\footnotetext{
Esse estudo abriu caminho para que outros pesquisadores realizassem investigações comparativas com o mesmo propósito, fornecendo base para generalizações a respeito da natureza e funcionamento do pensamento de sujeitos pertencentes a sociedades tradicionais (VÓVIO, in: OLIVEIRA; OLIVEIRA, 1999, p. 120-121).
}

\subsubsection{Escolarização de jovens e adultos}

A escolarização muitas vezes parece ser vista como uma política pública que, se aplicada a populações analfabetas, traria desenvolvimento econômico e social, pois desenvolveria formas de pensar mais "avançadas" em determinados povos. Para Cole (1996), sem transformações mais profundas e consequentes na sociedade, mesmo os efeitos benéficos de uma boa escolarização não resultariam nos efeitos desejados. Isso quando a própria educação não se torna uma maneira de reproduzir desigualdades. Mesmo 
assim, a escola é uma instituição que poderia fornecer importantes instrumentos para o pensamento, oferecendo importantes condições capacitadoras, embora não seja a única (COLE, 1996).

As sociedades contemporâneas são extremamente complexas. As diferenças de classe, raça, gênero, orientação sexual, posicionamentos políticos ou religiosos, bem como a participação dos indivíduos em diferentes grupos, associações e movimentos, propiciam o desenvolvimento de muitas diferenças entre os indivíduos. Cada uma dessas diferenças, por sua vez, pode dialogar mais ou menos com a cultura escolar, com aquilo que a escola, como instituição constituída historicamente, espera dos alunos. Dentro dos seus limites e possibilidades, a escola diagnostica, informa, constrói conhecimentos e avalia os alunos, lidando cotidianamente com a diferença entre indivíduos. Quando algum aluno, por alguma razão não se "enquadra" nas expectativas da escola, tende a ser considerado "deficitário" em seu desenvolvimento.

Assim, a escola reproduziria muitas desigualdades, particularmente para os alunos da EJA. Para Fonseca (2002), os próprios alunos parecem ter consciência disso, pois muitas vezes selecionam os conhecimentos que julgam ser relevantes a ponto de serem apresentados no contexto escolar, enquanto ocultam outros. Importante ressaltar também o quanto os alunos reproduzem a ideologia de que a sua exclusão ou fracasso escolar se deve não a problemas referentes às dificuldades que enfrentam enquanto classe social (incluídas aí todas as problemáticas referentes à raça, gênero, orientação sexual, territorialidade, etc.), mas a fatores individuais, culpabilizando a si próprios pela sua trajetória escolar descontínua. Essa ideologia reforça a exclusão, na medida em que desresponsabiliza o poder público pelas demandas da EJA, além de naturalizar os conflitos em sala de aula entre a cultura trazida pelos alunos e as expectativas escolares. Na verdade, é comum que se "importe" técnicas originalmente pensadas para o ensino de crianças para a EJA: 
representações que Ihes atribuem os professores, a escola, o sistema, ou a sociedade, tendem a não formular explicitamente o seu desconforto ou constrangimento diante de tais ações pedagógicas (nesse aspecto, numa atitude bastante diferenciada da assumida por adolescentes e mesmo jovens), mas se deixam invadir pelo desinteresse e pelo desânimo, alimentado, principalmente, pela impossibilidade de conferir sentido àquilo que se veem obrigados a realizar (FONSECA, 2002, p. 37).

A Educação de Jovens e Adultos deve, portanto, considerar como legítimos os saberes dos alunos, adquiridos e construídos nas suas vivências. Como instituição, a escola demanda práticas próprias, a partir de uma cultura escolar, que em geral é bastante diferente da cultura não escolar trazida pelos alunos da EJA. Isso raramente é levado em consideração de maneira consequente pelas unidades escolares. Muitas vezes, as propostas escolares colocam os alunos frente a atividades por eles desconhecidas. Assim, os procedimentos escolares deveriam ser trabalhados juntamente com os conteúdos em si (MOURA, 1999).

Dessa maneira, para Oliveira (2009), a escola tradicional possuiria uma dinâmica civilizadora, elencando uma série de habilidades essenciais para 0 bom desempenho escolar, pontuando as diferenças culturais e hierarquizandoas. Nessa perspectiva, o aluno que não corresponde às expectativas dessa escola tem a sua voz desautorizada, por não corresponder intelectualmente àquilo que se espera dele, especialmente quando adolescente ou adulto. Em reação a essa visão, haveria uma tendência na Ciência Cognitiva em relativizar, quando não negar, a importância da diferença cultural. Nessa perspectiva, embora se queira quebrar com o paradigma de que haveria apenas um caminho ideal de desenvolvimento humano (notadamente ligado à civilização ocidental moderna) e valorizar a cultura dos alunos, em especial os provenientes das camadas populares, a escola acaba por ter o seu espaço de atuação reduzido, interferindo pouco no desenvolvimento desses sujeitos.

Para a autora, a duas primeiras perspectivas, apesar de opostas, levam ambas, a um imobilismo na educação. Se por um lado, o modelo tradicional 
postula que as diferenças são inatas, e que determinados alunos considerados deficitários não seriam capazes de apreender conteúdos importantes do conhecimento científico, essa perspectiva consequentemente responsabiliza o aluno pelo fracasso, naturalizando desigualdades. Se por outro lado, o cognitivismo postula que as diferenças são irrelevantes porque no fundo correspondem a processos psíquicos semelhantes, a escolarização perde 0 seu caráter transformador, se limitando ao que os alunos já sabem previamente, em detrimento daquilo que poderiam aprender, diminuindo muito o horizonte cultural que a escola poderia propiciar.

Dessa forma, Oliveira (2009) postula a necessidade de pensar as diferenças culturais em alunos jovens e adultos sob um prisma diferente e, assim, reavaliar o papel da escola a partir de uma abordagem genética "forte". A partir da Teoria Histórico-Cultural, considera-se que há, sim, muitas diferenças produzidas nas interações sociais. Isso porque haveria quatro planos que originariam o desenvolvimento psíquico: a filogênese (produto da evolução das espécies e resultante de características como a plasticidade do cérebro ou a destreza nas mãos para o trabalho), a ontogênese (desenvolvimento orgânico ao longo da vida do indivíduo, possibilitando a maturação dos sistemas do organismo), a sociogênese (a "herança cultural" dos povos, o acúmulo de saberes ao longo da história) e a microgênese (processos de constituição psíquica específicos, como um episódio em sala de aula, uma conversação entre indivíduos em um dado contexto, etc.). A partir daí, a autora afirma que

A imensa multiplicidade de conquistas psicológicas que ocorrem na vida de cada indivíduo gera uma complexa configuração de processos de desenvolvimento que será absolutamente singular (grifo nosso) para cada sujeito (OLIVEIRA, 2009, p. 45).

Para a autora, o desenvolvimento humano, embora marcado pelos limites e possibilidades da filogênese e da ontogênese, se daria, portanto, a 
partir da aprendizagem, das interações sociais na cultura. É verdade que a escola não seria o único espaço em que isso seria possível; por outro lado, uma boa escola possibilitaria de maneira privilegiada que a partir da mediação de outros sujeitos, de signos e de instrumentos, novos significados e sentidos pudessem ser internalizados.

Embora não haja um modelo de "bom funcionamento psicológico" do ser humano, a escola teria um papel de promoção intencional do desenvolvimento dos sujeitos. Nesse momento histórico, em uma sociedade industrializada, letrada e burocratizada, a escola é o lugar de socialização das formas de pensamento científico e sistematizado, contribuindo assim para a inserção dos sujeitos em sua própria cultura. Não se trata de "acelerar" ou "compensar" o desenvolvimento de determinados alunos considerados "deficitários", tampouco de esperar um "espontaneísmo" no seu desenvolvimento cognitivo a partir da entrada na escola. O que se coloca aqui é a necessidade de uma educação que se caracterize por uma promoção intencional do desenvolvimento, situando o sujeito em uma sociedade letrada historicamente constituída e possibilitando a sua participação em práticas sociais significativas.

A escola parece, assim, de fato impactar no desenvolvimento cognitivo dos indivíduos escolarizados. Não parece, no entanto, garantir um papel determinante no desenvolvimento global desses sujeitos:

Um indivíduo escolarizado pode ser mais capacitado para resolver silogismos, por exemplo, mas não será necessariamente mais bem orientado no espaço que um sujeito não escolarizado; pode ter mais desenvoltura em processos de classificação de objetos, mas não sabemos se terá mais equilíbrio emocional ou maior facilidade no convívio com as pessoas; pode realizar inferências com base em regras lógicas, mas não ser particularmente habilidoso em tarefas que exijam destreza manual. Assim sendo, uma comparação global entre escolarizados e não escolarizados não faz sentido: além de o processo de escolarização atuar num âmbito específico de competência intelectual, não transformando a psiquê inteira do sujeito, mas apenas parte dela, esferas de atividade que não têm relação com o pensamento científico ou especificamente letrado podem demandar outras modalidades de 
funcionamento psicológico não mais bem dominadas pelos sujeitos escolarizados (OLIVEIRA, 2009, p. 172).

Dessa maneira, a escolarização possibilitaria uma significativa transformação na aquisição de formas de pensamento conceitual ou letramento, mas não se poderia afirmar que ela garantiria um desenvolvimento global qualitativamente superior aos dos sujeitos não ou pouco escolarizados. Ela possibilitaria as condições para que indivíduos escolarizados possam se apropriar de certas formas de operações mentais, não sendo o processo educativo uma espécie de "motor" evolutivo, elevando todo o desenvolvimento psíquico dos indivíduos a níveis superiores de pensamento. Por outro lado, a escolarização não seria a única prática social a possibilitar a apropriação de saberes e operações complexas de pensamento.

Em suas pesquisas, Kleiman (1995) traz uma interessante reflexão sobre como os sujeitos adultos podem se apropriar de práticas sociais que utilizam a escrita fora da escola, particularmente em sociedades contemporâneas, embora a escola possua alguma especificidade quanto ao letramento. Para a autora,

O fenômeno do letramento, então, extrapola o mundo da escrita tal qual ele é concebido pelas instituições que se encarregam de introduzir formalmente os sujeitos da escrita. Pode-se afirmar que a escola, a mais importante das agências de letramento, preocupa-se, não com o letramento, prática social, mas com apenas um tipo de prática de letramento, a alfabetização, o processo de aquisição de códigos (alfabético, numérico), processo geralmente concebido em termos de uma competência individual necessária para o sucesso e promoção na escola. Já outras agências de letramento, como a família, a igreja, a rua como lugar de trabalho, mostram orientações de letramento muito diferentes (KLEIMAN, 1995, p. 20).

Para a autora, não se pode afirmar que fora da escola os sujeitos não se apropriem de condições de uso da escrita, porque haveria muitas outras agências de letramento com práticas diferentes daquela que ocorre no espaço 
escolar. Por outro lado, a escolarização muitas vezes reproduz um modelo dominante de letramento, a partir de uma dicotomia entre alfabetizados e não alfabetizados. Nesse sentido, para Vóvio (1999), pode-se afirmar sobre as diferenças entre sujeitos que

[...] uma visão dicotômica entre formas de funcionamento cognitivo de pessoas escolarizadas e de pessoas não escolarizadas tende a ser superada, dando lugar a uma perspectiva de análise que considere, além do fator escolarização, as atividades e demandas a que os sujeitos estão submetidos nas culturas de que fazem parte. As práticas e usos da linguagem também devem ser consideradas como variáveis que intervém no funcionamento da mente (VÓVIO, 1999, p. 29).

Para a autora, há muito a se pesquisar sobre como operam os processos mentais de sujeitos pouco ou nada escolarizados em sociedades letradas. Isso porque, se é verdade que a escolarização traz grande impacto para as formas de pensamento, também é verdade que ela seria apenas uma das práticas culturais que constituiriam o desenvolvimento psíquico dos sujeitos, que podem se desenvolver e se transformar a partir de outras vivências, que nem sempre são valorizadas no espaço escolar.

Há ainda uma importante questão a se considerar. Segundo Camargo (2006), apesar de os alunos de Educação de Jovens e Adultos apresentarem elementos culturais significativos e que deveriam ser levados em conta no seu processo de escolarização, é comum que a escola desvalorize sobremaneira seus conhecimentos marcados pela oralidade, privilegiando apenas a linguagem escrita, da qual ainda não se apropriaram adequadamente:

Já os alunos, que dominam a modalidade oral do uso da língua e que ainda não escrevem, muitas vezes se calam nas aulas alegando que nada sabem porque ainda não sabem escrever. Essa relação que fazem entre conhecimento e registro escrito (e que os faz desprezar os próprios conhecimentos e experiências) fundamenta-se em quê? Essa questão, somada à 
consideração da fala dos alunos pelos professores, merece atenção, pois pode ser uma das causas da evasão, na constatação (dos alunos) de que a escola realmente não é pra eles (CAMARGO, 2006, p. 9).

Haveria, portanto, um conflito entre determinadas formas de expressão e linguagem valorizadas pela escola e a cultura dos alunos de EJA que, longe de mediar a língua materna ou os conceitos cotidianos com a linguagem escrita escolar e os conceitos sistematizados, atuaria desprestigiando a oralidade e, no limite, contribuindo para a exclusão dos alunos. Não apenas a fala é considerada incorreta, mas o próprio sujeito passa a ser estigmatizado pela linguagem por ele utilizada.

Para Vóvio (1999), a oralidade é bastante importante para alunos da EJA, e nem sempre valorizada ao longo da escolarização. Apesar das diferenças, escrita e oralidade se influenciariam mutuamente, em que pese que nas sociedades contemporâneas a primeira é mais prestigiada que a segunda. Essas trocas entre oralidade e escrita ocorrem no contexto sócio-histórico da comunicação entre sujeitos, a partir dos elementos culturais disponíveis para eles.

Para a autora, uma boa escolarização poderia garantir que os sujeitos se situassem melhor nas sociedades contemporâneas, profundamente marcadas pela escrita, pela urbanização e por uma série de procedimentos burocráticos que normatizam a vida dos indivíduos. No Brasil,

De modo geral, pode-se afirmar que essa parcela substancial da população não teve acesso aos modos de operar tipicamente letrados, por não compartilhar de práticas culturais próprias da sociedade da qual faz parte e, em consequência, de procedimentos, de modalidades de operação cognitiva e de conhecimentos característicos das sociedades modernas. Como consequência, jovens e adultos não ou pouco escolarizados estariam alijados dessas práticas culturais, diferentemente daqueles que passaram pelo processo de escolarização, porém encontram-se imersos em situações nas quais a linguagem escrita é central (VÓVIO, 1999, p. 8). 
Portanto, a problemática dos adultos não ou pouco escolarizados em sociedades letradas requer grande aprofundamento teórico por parte dos pesquisadores, pelo fato de que aqueles sujeitos estão em um contexto sóciohistórico que lhes exige certas habilidades cuja apropriação se deu de maneira "informal" (isto é, não passaram o suficiente pela escolarização formal) e por vezes insuficiente, mas não de forma inapropriada ou inadequada. Segundo Vóvio,

[...] pessoas que não passaram pela escola e que vivem em sociedades cujas demandas comunicativas impõem 0 planejamento do discurso por meio da escolha e da explicitação de informações e a construção de um discurso coerente e sequenciado, acabam por lidar com problemas apontados por vários pesquisadores como típicos da linguagem escrita. Esses problemas exigem operações cognitivas como a descontextualização, proveniente da necessidade de planejar e realizar previsões sobre o próprio discurso; a seleção de informações e sua explicitação para se fazer compreender pelos interlocutores; além do controle do discurso, regulado internamente, dirigido por uma intenção e um projeto comunicativo (VÓVIO, 1999, p. 20).

O letramento parece ser, dessa forma, parte da formação cultural desses sujeitos, independente de frequentarem a escola ou não. A apropriação da comunicação escrita se daria de maneira incompleta, mas muito ligada a demandas práticas da vida cotidiana: utilização de transporte público, ditado e envio de cartas para parentes de outras regiões do país, leitura de preços das mercadorias em estabelecimentos, utilização de redes sociais.

Ao entrar em contato com o ensino formal, por meio da Educação de Jovens e Adultos, os alunos se submeteriam a uma significativa aquisição de conhecimento, pelas relações pedagógicas propostas. Em que pese o fato de que os sujeitos podem se apropriar da linguagem escrita e dos meios de comunicação de uma sociedade contemporânea em outros espaços culturais, 
sem dúvida a passagem pela (ou retorno a) escola possibilita um salto de qualidade em sua relação com sociedades urbanas e burocratizadas.

Ao pesquisar o impacto da alfabetização em jovens e adultos pouco escolarizados, Vóvio (1999) percebeu que nos casos em que a escrita é subutilizada cotidianamente pelo sujeito, a apropriação da linguagem escrita se dá de maneira insatisfatória, ao passo que, nos casos em que, apesar da pouca escolaridade, os sujeitos se encontram em situações que demandam a utilização da linguagem escrita, sua apropriação parece ser mais consistente, tendo se desenvolvido inclusive anteriormente à sua chegada ou retorno à escola na EJA. Tulviste (1991) teria chegado a conclusões semelhantes, como vimos anteriormente.

A escolarização seria, portanto, uma das práticas sociais dentre outras, a, no contexto de uma sociedade industrializada e burocratizada, possibilitar formação de pensamento conceitual ou a participação do sujeito em práticas de letramento. Adultos não escolarizados podem desenvolver certas operações mentais típicas de sociedades letradas, caso estejam interagindo em situações cotidianas ligadas ao trabalho ou a atividades culturais relacionadas ao hábito da leitura. Dessa forma

\begin{abstract}
Não se trata de desconsiderar o papel da escola como uma das principais agências sociais responsáveis por propiciar aprendizagens necessárias à participação plena e exercício de cidadania, mas, alternativamente, de considerar que se suas metas e aprendizagens estão relacionadas a sua aplicabilidade em outros âmbitos sociais (o trabalho, a participação em atividades políticas, comunitárias, religiosas e sociais, entre outros), a participação nesses âmbitos também promove aprendizagens (VOVIO, 1999, p. 204).
\end{abstract}

Para a autora, o processo de escolarização não garante nem é o único elemento cultural que possibilitaria um desenvolvimento cognitivo próprio de sociedades letradas aos alunos da EJA. A falta de práticas sociais ligadas à linguagem escrita faria com que determinados sujeitos apenas a utilizassem no 
contexto escolar; a sua apropriação, nesse caso, tenderia a ser particularmente limitada. Ao contrário, a utilização da linguagem escrita em contextos culturais externos à escola possibilitaria uma apropriação singular da linguagem escrita ou de um pensamento conceitual, ainda que por caminhos diversos dos propostos pela escolarização formal. Para autora, seria possível dizer, sem um juízo de valor, que há pelo menos duas modalidades de pensamento, a lógicocientífica, demandada pela sociedade industrializada, urbanizada, burocratizada e letrada, e a narrativa, ligada a sociedades tradicionais e orientada para a resolução de problemas práticos e particulares, fundamentais para certas comunidades (VÓVIO, 1999).

Por fim, a escola parece possibilitar a aquisição, por parte dos alunos jovens e adultos, de formas de pensamento conceitual típicas de sociedades industrializadas, burocratizadas e letradas. Porém, se para a perspectiva da Teoria Histórico-Cultural, a cultura é constitutiva dos processos de desenvolvimento cognitivo dos sujeitos, apenas a escolarização não garantiria a formação de funções psicológicas superiores como o pensamento conceitual sistematizado, pois os processos de transformação psíquicos pelas quais passam os sujeitos ocorreriam em meio a um conjunto de interações sociais e culturais muito mais amplos e complexos.

\subsection{Escolarização e Teoria Histórico-Cultural}

Tradicionalmente, considera-se que a instituição responsável pela educação das novas gerações, a partir das necessidades das sociedades industriais, é a escola. A escolarização tem uma reconhecida importância no desenvolvimento dos sujeitos, aprimorando-Ihes operações e habilidades específicas como a linguagem, fornecendo-lhes noções e conhecimentos científicos e artísticos, de maneira sistematizada. Entretanto, a maior parte dos sujeitos envolvidos nela, como pais, professores, intelectuais e alunos, parece concordar apenas em um ponto nos dias atuais: a escola não tem dado conta daquilo a que se propõe. Os processos de ensino, aprendizagem e 
desenvolvimento parecem bastante prejudicados e a educação escolar parece amargar um fracasso crônico.

Como e em que condições essa crise teria historicamente se iniciado? Segundo Geraldi (2010), nas sociedades tradicionais da Antiguidade e da Idade Média, a escola seria um espaço de produção de saberes, onde o professor era um mestre, um fundador de uma certa forma de pensar, e os alunos, seus aprendizes. A partir da Idade Moderna, em meados dos séculos $\mathrm{XV}$ e XVI, iniciou-se uma divisão do trabalho entre aqueles que produzem o saber (pensadores, sábios, filósofos, professores de universidades) e aqueles que devem ensiná-lo aos alunos (os professores das escolas básicas), que passavam a ser vistos também como receptáculos do conhecimento. Com o avanço das Revoluções Industriais até meados do século XX, essa divisão se aprofundou. No mundo contemporâneo, o saber, produzido pela ciência em meios acadêmicos, seria transmitido pelas editoras de livros didáticos, apostilas e sistemas de ensino aos professores, que já não detêm mais o saber, mas devem dominar técnicas eficientes para transmiti-los aos alunos. Esses, por sua vez, passam a ser responsabilizados individualmente pela sua capacidade ou não de "absorver" e "reproduzir" esses conteúdos e habilidades. Para o autor, esse modelo de educação não só tem trazido inúmeros problemas nas práticas pedagógicas em sala de aula, como se encontra desde as últimas décadas do século XX em flagrante crise. Criou-se assim uma enorme distância entre uma produção dos saberes científicos que menospreza o conhecimento e a cultura de professores e alunos.

Segundo Carreteiro e Limón (1997), desde os anos 1980 surgiram muitos trabalhos preocupados com o que os alunos sabem previamente quando estudam determinados conteúdos escolares. Apesar dos limites de várias dessas pesquisas, constatou-se que a dificuldade dos alunos em apreender os conteúdos de áreas como a História poderia estar relacionada à distância do objeto de conhecimento do cotidiano das crianças. Por outro lado, as novas interpretações da História com relação ao passado encontram 
dificuldades de serem trabalhadas com os alunos, por estarem ligadas a valores muito arraigados:

Também é muito possível que os conhecimentos históricos apresentem maior resistência à mudança, quando comparados a outros tipos de conhecimentos escolares, pois costumam ter alto valor emocional e afetivo ao fazerem parte das identidades coletivas e nacionais. Assim, seria previsível que mudar nossa representação da descoberta da América ou da expulsão dos árabes em 1492 fosse mais difícil que transformar nossas ideias sobre a evolução das espécies ou a composição da matéria (CARRETEIRO; LIMÓN, In: ARNAY; RODRIGO, 1997, p. 177).

Nesse sentido, haveria sempre uma "luta" entre o conhecimento científico, trazido por um contexto "não natural", externo ao cotidiano do aluno e à sua bagagem prévia. Há muitas teorias que partem de pressupostos diferentes para explicar o que muda cognitivamente na passagem do conceito cotidiano para o científico na escola, desde as que defendem a convivência de diferentes formas de compreensão (mudando apenas o contexto de utilização), até as que defendem que há uma completa reestruturação do pensamento da criança. Mesmo assim, todas convergem para a conclusão de que a formação do pensamento conceitual é lenta, processual e conflituosa intelectual e emocionalmente. Não se pode exigir, evidentemente, que os alunos compreendam todos os conteúdos escolares; talvez o objetivo da escolarização fosse mais constituir uma certa maneira de reflexão sistematizada, que os seus resultados propriamente ditos (CARRETEIRO; LIMÓN, 1997).

Para Fontana (2005), a escola contemporânea teria a possibilidade de mediar as elaborações dos alunos em meio às contradições de uma sociedade de classes. Essa mediação tem um grande impacto no seu desenvolvimento, em que pesem todas as limitações da educação pública como está posta historicamente no país. Mesmo assim, sua importância tem sido subestimada, não se considerando que a relação do sujeito com o mundo é indireta, influenciada pelo outro, por um signo ou instrumento. Com todas as 
contradições que carrega, a escola é um espaço privilegiado de mediação do sujeito com o seu tempo histórico.

Para a autora, é comum ainda hoje uma visão maturacionista, esperando-se que o desenvolvimento quase espontâneo de determinadas operações cognitivas seja condição prévia para o domínio do saber escolar. Impera a consideração do aluno não a partir de suas particularidades, advindas de determinado contexto social e cultural, mas a partir daquilo que Ihe falta, que Ihe é ausente, em termos de habilidades próprias da cultura escolar, em relação ao que se espera dele em determinada idade/ano, ou em relação àquilo que a maioria de seus colegas de sala apresenta. Consequentemente, patologizam-se os sujeitos que não trazem esses requisitos.

Assim, a suposta solução para esses alunos, vistos como sujeitos com "defasagens", se dá na tentativa de "corrigir" essa espécie de "déficit", para que alcancem o mesmo padrão da maioria, ou o que se convencionou ser o ideal para o seu estágio de desenvolvimento. Importa, dessa forma, menos o processo de ensino promovido pela educação escolar, tendo como mediador privilegiado o professor, e mais as estratégias adotadas para aproximar os sujeitos "com defasagens" do seu suposto nível de desenvolvimento ideal. Para Fontana,

O professor tem seu papel secundarizado na relação de ensino com a criança, que é quem dirige a aprendizagem, e na condução do processo educativo como um todo, uma vez que sua concepção e planejamento ficam a cargo de outros especialistas (FONTANA, 2005, p. 5).

Dessa maneira, faz-se necessário compreender as interações no espaço escolar não buscando apenas exclusivamente o que falta para professores e alunos, mas sim compreender como essas relações têm se dado concretamente. Para refletir sobre a educação não podemos falar dela em 
abstrato, mas da educação que ocorre em um dado contexto sócio-histórico, e que impacta a vida de sujeitos que estão todos os dias nas salas de aula.

A partir da Teoria Histórico-Cultural, iniciada por Vigotski e de outros autores que o sucederam, uma interessante perspectiva sobre as questões do desenvolvimento psicológico humano tem sido discutida. Parte-se da premissa de que a cultura, contextualizada historicamente, é constitutiva do desenvolvimento humano, configurando em cada indivíduo de forma particular as chamadas funções psicológicas superiores (memória, atenção dirigida, linguagem, imaginação, pensamento, etc.) que nada mais são do que relações sociais internalizadas. O desenvolvimento se daria de maneira dialética; consequentemente a cultura formaria o sujeito e seria produzida ao mesmo tempo por ele (VIGOTSKI, 2000).

A partir dessa perspectiva teórica, a formação do pensamento seria uma função psicológica superior, sendo particularmente importante nesse momento histórico o impacto da escolarização nesse processo. O pensamento conceitual seria mediado socialmente, e possibilitaria ao sujeito refletir sobre o mundo a partir de conceitos científicos ou sistematizados.

Para Fontana (2005), o pensamento conceitual seria importantíssimo porque permitiria aos indivíduos refletirem sobre suas experiências. Sobre a gênese do pensamento, afirma que

Vistos desta ótica, os conceitos não são analisados como categorias intrínsecas à mente, nem como reflexo da experiência individual, mas sim como produtos históricos e significantes da atividade mental mobilizada a serviço da comunicação, do conhecimento e da resolução de problemas (FONTANA, 2005, p. 13). 


\subsubsection{0 pensamento por conceitos: uma polêmica}

A Psicologia, como toda área do conhecimento, tem sido produzida a partir de determinados contextos históricos. As teorias que de suas pesquisas derivam, longe de serem universais, estão relacionadas a determinadas perspectivas acerca do homem e seu desenvolvimento.

Talvez por isso, Vigotski, em muitos textos, tenha escrito longos e aprofundados comentários sobre as teorias psicológicas da época (VIGOTSKI, 2010). Sua generosidade the permitia reconhecer importantes avanços dos autores que $o$ antecederam ou com os quais queria polemizar (incorporando inclusive elementos teóricos), mas, ao mesmo tempo, não o impedia de atacar sem concessões os seus pontos fracos, evitando, assim, cair em uma espécie de ecletismo. Vamos recuperar um pouco dos comentários do autor sobre as discussões da Psicologia no início do século XX, a fim de compreendermos o ambiente intelectual em que se situava Vigotski, quais eram as polêmicas e quais as suas ponderações sobre cada visão a respeito do pensamento, e como, a partir delas, chegou às suas próprias conclusões.

Para o autor,

Qualquer inventor, mesmo um gênio, é sempre um fruto de seu tempo e de seu meio. Sua criação surge de necessidades que foram criadas antes dele e, igualmente, apoia-se em possibilidades que existem além dele. Eis porque percebemos uma coerência rigorosa no desenvolvimento histórico da técnica e da ciência. Nenhuma invenção ou descoberta científica pode emergir antes que aconteçam as condições materiais e psicológicas necessárias para seu surgimento. A criação é um processo de herança histórica em que cada forma que sucede é determinada pelas anteriores (VIGOTSKI, 2009, p. 40).

A ciência não seria, portanto, portadora de um conhecimento imutável cujos resultados seriam inquestionáveis. Pelo contrário, os cientistas são sujeitos do seu tempo histórico, e produzem suas pesquisas somente a partir 
dessa localização. Isso não significa em absoluto que sejam meramente determinados pelo seu contexto sócio-histórico, mas, sim, que constroem suas teorias a partir de necessidades de seu tempo e não raro apontam para novas criações científicas, capazes de revolucionar a relação do homem com a natureza.

A partir da Segunda Revolução Industrial, em meados do século XIX, o avanço técnico-científico impressionava a todos; acreditava-se nas ciências como um fator de progresso para as nações. Dando continuidade a isso, no início do século $X X$, proliferaram os métodos experimentais na psicologia. $A$ observação de crianças, adolescentes, adultos, deficientes, pessoas lesionadas, especialmente se confrontadas com "problemas" a serem solucionados nas experiências, era uma metodologia considerada "científica" para se estudar in loco os fenômenos psíquicos.

No entanto, alguns pesquisadores passaram a desconfiar que os métodos experimentais não eram "neutros" e que, a partir de um determinado viés, eram capazes de produzir condições que levavam aos mais variados resultados, contribuindo para teorias que naturalizavam desigualdades sociais ${ }^{5}$ ou que, na melhor das hipóteses, nem sempre se mostravam capazes de explicar os processos psicológicos em questão, como o pensamento por conceitos.

Vigotski se preocupava em contextualizar historicamente as correntes da Psicologia da época, a fim de demonstrar o percurso do desenvolvimento histórico desse campo do conhecimento e os problemas dessas perspectivas. Em A construção do pensamento e da linguagem (2010), originalmente publicado em 1934, inicia seus comentários sobre a Psicologia da época, particularmente sobre como as diversas correntes da época analisavam a formação do pensamento conceitual, que métodos utilizavam, e a que conclusões chegaram.

\footnotetext{
${ }^{5}$ Sobre o papel da Psicologia na ideologia dominante, foram importantes no Brasil os estudos de Patto (1984).
} 
Para o autor, o método da definição, consistia em "investigar os conceitos já formados na criança através da definição verbal de seus conteúdos." (VIGOTSKI, 2010, p. 151). Para ele, os resultados dessas pesquisas atestariam apenas o resultado final da formação de conceitos, ou seja, a utilização da palavra por parte das crianças estudadas, e pouco questionava se o sentido dado por elas à palavra se aproximava ou não do seu significado social. O mecanismo psicológico de formação de conceitos permanecia desconhecido, bem como a relação entre a palavra utilizada pela criança e sua experiência com a realidade:

O essencial mesmo para o conceito - a sua relação com a realidade - fica aí sem ser estudado; procuramos chegar ao significado de uma palavra através de outra palavra; e o que descobrimos mediante esta operação deve antes ser atribuído a relações existentes entre certas famílias convencionais de palavras que à efetiva representação dos conceitos infantis (VIGOTSKI, 2010, p. 152).

Seguindo com o seu balanço sobre a Psicologia da época, o autor comenta que os métodos de estudo da abstração por outro lado tinham como preocupação descobrir, por meio de experimentos, como a criança poderia, através da sua percepção, generalizar um traço comum de uma série de impressões concretas de objetos (Ibidem, p. 152). Não há dúvida da importância desse processo, mas, para Vigotski, ele não contemplaria a análise do pensamento conceitual por ignorar o papel da palavra, que medeia significado e pensamento e se faz presente na linguagem. A palavra é portadora do significado atribuído socialmente a ela:

Com isso, simplificam infinitamente o próprio processo de abstração, por tomá-lo fora daquela relação específica com a palavra, característica da formação de conceitos, que é o traço distintivo central de todo o processo (Ibidem, p. 153). 
Segundo Vigotski, um primeiro avanço importante teria sido dado por estudos que buscavam observar tanto o papel da palavra, quanto o processo a partir do qual os sujeitos classificavam objetos, levando à formação de conceitos. Entre os pensadores que promoveram este salto qualitativo, estavam Ach, Rimat e Uznadze (apud VIGOTSKI, 2010). Esses autores teriam concluído que, ao contrário do que afirmavam importantes correntes de pensamento em voga na passagem do século XIX para o $X X, 0$ desenvolvimento do pensamento ao longo da vida dos sujeitos não era um amadurecimento de funções constituídas nos primeiros anos de vida, mas se dava pelo aparecimento de formas qualitativamente novas de pensamento em diferentes idades. Outra contribuição importante seria a hipótese de que o pensamento conceitual não se dava por um pensamento associativo, que graças às faculdades herdadas da evolução das espécies, possibilitaria ao intelecto relacionar naturalmente os atributos dos objetos, e sim pela resolução orientada de problemas, a chamada tendência perseverante. $O$ pensamento por conceitos seria, pois, produtivo, e não meramente reprodutivo (VIGOTSKI, 2010).

Entretanto, para Vigotski, a problemática do melhor método para se chegar à explicação (e não apenas à descrição) dos diferentes tipos de pensamento que um sujeito elabora ao longo do seu desenvolvimento, bem como do processo de passagem de uma a outra, permanecia.

Nesse sentido, o método da dupla estimulação, elaborado por um de seus colaboradores, Sákharov, permitiu, segundo o próprio Vigotski, a observação da interação dos sujeitos com objetos concretos, ao mesmo tempo em que trabalhava a questão das palavras em torno das quais essa atividade se realiza (Ibidem). O trabalho conjunto desses pesquisadores nos primeiros anos após a Revolução de Outubro permitiu o avanço de grandes pesquisas; destaca-se a contribuição de Vigotski, que pôde realizar experimentos com mais de 300 crianças a fim de elaborar sua teoria genética a respeito do desenvolvimento humano, e assim estudar o pensamento, entre outras funções psicológicas. 
Vigotski tributava grande respeito a outro pesquisador, seu contemporâneo Jean Piaget (1896-1980). Direcionava às suas pesquisas também algumas críticas. Segundo ele, Piaget foi o primeiro a perceber que, quando a Psicologia falava de pensamento por conceitos, estava na verdade se referindo aos conceitos espontâneos; a partir daí o autor bielo-russo tratou de diferenciá-los dos conceitos não-espontâneos ou científicos, que necessitam de um processo intencional e educativo para se constituírem (VIGOTSKI, 2010). Piaget acreditava que os conceitos espontâneos, ou seja, aquilo que a criança já sabe e que é significativo de seu atual estágio de desenvolvimento, representam a essência do pensamento concreto infantil, objeto de estudo da psicologia cognitiva (PIAGET; INHELDER, 1976). Nessa perspectiva, o pensamento infantil seria gradativamente superado com suas características autistas, e levaria consigo os conceitos espontâneos. Ao longo do seu desenvolvimento, ocorreria uma ruptura, em que o pensamento por conceitos científicos tomaria o lugar do pensamento por conceitos espontâneos, próprio do pensamento infantil e que aos poucos desapareceria. Dessa maneira, para Piaget, o desenvolvimento do sujeito se daria de forma evolutiva, progressivamente, no sentido do pensamento socializado.

Para Oliveira (2009), as conclusões da Psicologia do início do século XX devem ser contextualizadas de acordo com as premissas e demandas da Ciência naquele contexto:

A obra de Vygotsky a respeito dos conceitos, baseada nos experimentos de Ach, é um exemplo claro da concepção clássica. Isso também se verifica com a obra de Piaget e Bruner, Goodnow \& Austin (1956) sobre desenvolvimento conceitual.

Essa abordagem sobre a natureza dos conceitos possui clara relação com determinada espécie de cognição, inserida em um determinado tipo de cultura, onde o conhecimento científico possui papel importante como padrão de conhecimento adequado e como modo apropriado de construção do conhecimento (OLIVEIRA, 2009, p. 288). 
Muitos foram os autores e correntes da Psicologia que se dedicaram ao estudo do desenvolvimento humano entre fins do século XIX e meados do século $X X .{ }^{6}$ Variavam tanto em relação a seus pressupostos filosóficos quanto em relação aos métodos que aplicavam, obtendo dessa forma resultados diferentes. Um dos méritos de Vigotski é fazer muitas vezes em seus escritos um balanço daquilo que já havia sido publicado em seu tempo, e a partir daí fazer suas colocações.

Mesmo com o acúmulo de teorias, restam ainda hoje práticas educativas que se resumem à utilização mecânica de palavras a suposta apreensão de conceitos científicos, desconhecendo os processos mentais ou os conceitos já formados nos alunos. Outras estacionam nos conhecimentos dos alunos, negligenciando a importância do conhecimento sistematizado na educação. Os mais espontaneístas acreditam que a criança por si só, em uma espécie de prática laissez-faire, chegará ao "progresso" do conhecimento científico.

Essa parte do trabalho não teve como pretensão um levantamento historiográfico acerca das teorias sobre a formação de conceitos na Psicologia, objetivo sem dúvida necessário, mas além dos limites desse trabalho. Tampouco esgotar as polêmicas de ordem metodológicas, epistemológicas e filosóficas. O que foi exposto mostra de forma modesta e sucinta que o estudo da formação de conceitos partiu de um acúmulo de saber considerável por parte de Vigotski, bem como de pressupostos e conclusões localizadas a partir das suas condições de produção históricas, que podem e devem ser questionados, como forma de contribuição para o debate. Esse percurso pode auxiliar inclusive em uma melhor compreensão das teorias de Vigotski.

\footnotetext{
${ }^{6}$ Destacam-se as pesquisas de Henry Wallon (1879-1962). Para o autor francês, a escola, como instituição social e histórica, tem um impacto significativo no desenvolvimento dos sujeitos, a ponto de, na chamada etapa categorial ou escolar, dos seis aos onze anos, criar condições para que, através do processo educativo, as crianças possam associar e dissociar determinadas características dos objetos, elevando a abstração no pensamento a outro nível, muito mais superior (OLIVEIRA, 2009).
} 


\subsection{2 .0 desenvolvimento do pensamento para Vigotski}

As transformações psíquicas que ocorrem ao longo da vida dos sujeitos chamaram a atenção, especialmente desde meados do século XIX, dos mais variados campos do conhecimento, particularmente da Psicologia.

Vigotski produziu muito sobre os mais variados temas da Psicologia, especialmente na década de 1930, a sua "década furiosa". Refutava algumas das principais explicações em voga no início do século $X X$ a respeito do desenvolvimento humano e da formação do pensamento por conceitos, que afirmavam que a origem dos processos mentais humanos é fisiológica, propiciada basicamente pela evolução das espécies. Discordava também de posicionamentos como os da Gestalt, os quais postulavam a quase independência da consciência em relação a uma base material e não iam, para o autor, além da explicação dos processos psicológicos superiores (COLE; SCRIBNER, Prefácio. in: VIGOTSKI, 2000).

A perspectiva da Teoria Histórico-Cultural iniciada por ele parte do princípio do papel da cultura como elemento constitutivo do desenvolvimento dos sujeitos. A internalização de relações sociais, historicamente contextualizadas, daria início no plano intrapsicológico ao desenvolvimento das funções psicológicas superiores, que se caracterizariam pela atividade mental consciente e intencional da imaginação, da memória, da atenção dirigida, da linguagem e do pensamento conceitual, dentre outros processos.

Assim, para Rego, "Devido a essas características, especificamente humanas torna-se impossível considerar o desenvolvimento do sujeito como um processo previsível, universal, linear ou gradual." (REGO, 1994, p. 58). A história do desenvolvimento humano na ontogênese não obedeceria, dessa forma, a etapas fixas e sucessivas de desenvolvimento, mas a uma trajetória formada por períodos de desenvolvimento mais lentos e outros mais acelerados, configurando crises seguidas de revoluções, cuja gênese estaria na mediação do outro, dos signos e dos instrumentos entre o indivíduo e a cultura. Não seria a maturação biológica a determinar as transformações ao 
longo da vida do indivíduo: "O principal critério de demarcação das diferentes etapas é, para Vigotski, o surgimento de formações qualitativamente novas na personalidade do sujeito." (OLIVEIRA, 2009, p. 344-345). Situações historicamente constituídas, como a escolarização, ganhariam nessa perspectiva uma grande importância na gênese das transformações psíquicas pelas quais passam os sujeitos.

A partir da Perspectiva Histórico-Cultural, considera-se que o primeiro estágio do desenvolvimento do pensamento da criança seria o pensamento sincrético, subdividido por sua vez em estágios menores. Ao contrário de outras perspectivas que defendem que o desenvolvimento se dá pela negação e superação das modalidades do pensamento infantil, Vigotski (2010) considera o pensamento sincrético de fundamental importância para a constituição do sujeito, pois é a primeira elaboração da realidade produzida pela criança e a partir dela se dará o salto para outras formas de pensamento superiores.

No pensamento sincrético, a criança tomaria a realidade sem se preocupar com a coerência de seu pensamento, criando com os objetos vínculos emocionais e subjetivos. Entretanto, há que se notar que, apesar de os elementos dos objetos não guardarem relação lógica entre si no pensamento da criança, estão relacionados pelos vínculos sugeridos pela sua percepção infantil (VIGOTSKI, 2010). "A mentira da criança tem como fonte a verdade interior da vivência emocional" (Idem, 2004, p. 37). Essa primeira relação com os objetos também é mediada pela linguagem partilhada com os demais sujeitos da cultura, não partilhando, porém, da mesma lógica do pensamento por conceitos, mais relacionada ao mundo adulto. Além disso, ainda que na ontogênese novas formas de pensamento se desenvolvam, não necessariamente o pensamento sincrético estaria fadado ao desaparecimento.

Para Vigotski (2010), o "estágio" seguinte, também com subdivisões, seria o pensamento por complexos. Também típico do pensamento infantil, mas constantemente presente no pensamento dos adultos, os complexos surgiriam a partir das imagens do pensamento sincrético, representando, 
porém uma conquista psicológica por propiciar um pensamento qualitativamente superior quanto à percepção da realidade. Ao contrário das impressões subjetivas da criança na fase anterior, no pensamento por complexos o sujeito pensa a partir da sua relação factual e imediata com os objetos concretos da realidade.

Naquele subestágio considerado por Vigotski o estágio mais puro do pensamento por complexos, o complexo em cadeia, “(...) o centro estrutural pode estar ausente. Elementos concretos particulares podem estabelecer vínculos entre si, evitando o elemento central ou a amostra" (VIGOTSKI, 2010, p. 187). Isso porque, segundo o autor, embora utilizando as palavras que para os adultos são conceitos, a criança não pensa por conceitos, mas por complexos. Utiliza a palavra para nomear um conjunto de características que encontrou nos objetos como se eles fossem uma coleção, um sobrenome de família que nomeia diferentes indivíduos. Mas ainda não compreendeu as características que, dissociadas dos objetos e em associação com outras características, são capazes de criar uma generalização abstrata que dê nome a um grupo de objetos, generalizando-os, mesmo eventualmente quando eles estão ausentes.

No pensamento por complexos, a criança partilha da função nominativa da palavra com os adultos e se comunica através dela, ocultando dos observadores menos atentos que o seu pensamento é diferente do pensamento por conceitos, embora utilize as palavras corretamente. Isso ocorre porque

[...] os complexos infantis, que correspondem ao significado das palavras, não se desenvolvem de forma livre e espontânea, por linhas traçadas pela própria criança, mas em determinados sentidos, que são previamente esboçados para 0 desenvolvimento dos complexos pelos significados das palavras já estabelecidos no discurso dos adultos (VIGOTSKI, 2010, p. 191). 
Ainda assim, o pensamento por complexos seria importantíssimo para o desenvolvimento dos sujeitos, pois significa uma primeira aproximação mais objetiva com a realidade, a partir do qual o verdadeiro pensamento por conceitos se constituirá.

Para Vigotski, as interações entre adulto e criança, especialmente pela linguagem, fazem com que eles partilhem o mesmo signo, mas não o mesmo significado, já que as operações mentais são completamente diferentes. Mesmo assim, é a partir da interação que, ao longo de seu desenvolvimento, a criança pode aos poucos desenvolver o pensamento pelos primeiros conceitos.

Uma fase intermediária, segundo o autor, seria a dos conceitos potenciais. Nela, haveria inclusive uma perda na variedade de sentidos que as palavras carregariam em relação ao pensamento por complexos, que depende basicamente dos vínculos e da experiência da criança com os objetos. Segundo Vigotski (2010), o pensamento por conceitos potenciais seria uma primeira e verdadeira tentativa de abstrair um determinado atributo dos objetos, operação ainda muito difícil para o sujeito e, por isso mesmo, delicada e restrita. O signo da palavra passaria a orientar mais o pensamento, ao invés da experiência. Comenta Vigotski que

\footnotetext{
Esse papel consiste em que, pela primeira vez, abstraindo determinados atributos, a criança destrói a situação concreta, o vínculo concreto dos atributos e, assim, cria a premissa indispensável para uma nova combinação desses atributos em nova fase (VIGOTSKI, 2010, p. 226).
}

Finalmente, Vigotski (2010) comenta sobre como, na adolescência, o pensamento por conceitos se desenvolveria, sem que as outras formas de pensar necessariamente se extingam. Dada a necessidade social do uso das palavras na linguagem, o adolescente (ou o adulto) pela primeira vez, as utiliza como verdadeiros conceitos, significando-as de acordo com as generalizações inerentes a esse processo. Começa a pensar não a partir dos objetos em 
direção aos signos que os nomeiam, mas a partir do signo da palavra e seu significado abstrato e constituído socialmente.

No entanto, nessa fase, o uso das palavras, ainda que esteja orientado para a atividade mental, se daria mais facilmente naquelas situações de uso cotidiano do conceito ligado a uma atividade. O pensamento por conceitos, embora surgindo genuinamente pela primeira vez na adolescência, não garantiria por si só a utilização descontextualizada e conscientizada das palavras, sendo para esse fim de especial importância a escolarização. Em geral, o pensamento por conceitos surge acompanhado da resolução de algum problema, ponto de partida da abstração. Poder-se-ia definir que

O conceito surge quando uma série de atributos abstraídos torna a sintetizar-se, e quando a síntese abstrata assim obtida se torna forma basilar de pensamento com o qual a criança percebe e toma conhecimento da realidade que a cerca (VIGOTSKI, 2010, p. 226).

O processo de desenvolvimento dos sujeitos, para Vigotski (2010), em direção ao pensamento conceitual, não é de forma alguma um destino a se cumprir, um caminho a ser percorrido necessariamente. Percebe-se nessa perspectiva o poderoso papel que a mediação do outro e da linguagem tem no desenvolvimento dos sujeitos. As características fisiológicas, produto da evolução das espécies e da maturação do organismo, não conduziriam ao desenvolvimento intelectual e emocional do sujeito por si só, sendo a interação social o elemento fundamental na passagem de um estágio ao outro do desenvolvimento.

Além disso, o desenvolvimento não se daria de uma forma linear e evolutiva em direção a uma forma de pensar necessariamente superior, em que cada estágio sucederia o anterior, destruindo-o. Para Oliveira (2009), não se pode nem mesmo afirmar que a passagem pela escola garante em todos os sujeitos a formação de um pensamento científico. Para Vigotski, 
Diversas formas genéticas coexistem como coexistem na crosta terrestre os mais diversos estratos de diferentes eras geológicas. Essa situação é antes uma regra que uma exceção no desenvolvimento de todo comportamento (VIGOTSKI, 2010, p. 228).

Enquanto para Piaget (1976) o desenvolvimento se daria pela interação entre sujeito e objeto do conhecimento, da assimilação à acomodação, passando de estágios menos complexos para outros mais complexos da cognição, em Vigotski $(2000,2010)$ percebe-se outra teoria para o desenvolvimento humano. Para ele, as novas formas de pensamento a serem conquistadas pelo sujeito ao longo do desenvolvimento se constituiriam pela mediação (conceito que comentaremos mais adiante) do outro, justamente a partir das antigas formas de pensamento, sem necessariamente destruí-las.

Mais que isso: além de ter nas interações sociais e suas mediações condição sine qua non para seu desenvolvimento, tem como fim o horizonte cultural dado pelas relações sociais, historicamente constituídas na cultura. Em cada período histórico, o desenvolvimento dos sujeitos se daria em um determinado sentido, constituindo de forma particular as funções psíquicas superiores, bem como a relação sistêmica entre elas. Segundo Luria,

Vygotsky interpretava as diferenças nas interpretações que se fazem da realidade como diferenças no sistema de elementos psicológicos que orientam tais interpretações. Do seu ponto de vista, a linguagem é o elemento mais decisivo na sistematização da percepção; na medida em que as palavras são, elas próprias, produto do desenvolvimento sócio-histórico, tornam-se instrumentos para a formulação de abstrações e generalizações e facilitam a transição da reflexão sensorial não-mediada para o pensamento mediado, racional (LURIA, 1990, p. 67). 


\subsubsection{Conceitos espontâneos e científicos}

Para Vigotski, as chamadas funções psicológicas superiores como o pensamento conceitual seriam constituídas a partir de relações sociais internalizadas da cultura. Embora não se possa afirmar que o adulto pense apenas por conceitos (é comum que haja outras formas, como o pensamento por complexos), frequentemente é essa a operação psicológica demandada nas formas de sociabilidade próprias do mundo adulto, especialmente nas sociedades contemporâneas, caracterizadas por serem industrializadas, burocratizadas, letradas e predominantemente urbanas.

A criança se comunica muito bem com os adultos por meio das palavras, ainda que não com o mesmo nível de trabalho com a língua. Entretanto, ao longo de seu desenvolvimento, o indivíduo, a partir da adolescência, começa a se apropriar das palavras como verdadeiros conceitos em determinadas atividades. Isso ocorre não apenas por causa da maturação de seu organismo, mas fundamentalmente porque, pela interação com os adultos e pela linguagem, os adolescentes se apropriam do pensamento conceitual. Ainda que em sua forma não completamente desenvolvida, o pensamento conceitual tem como orientação a mediação da palavra.

Dessa forma, Vigotski identifica, no pensamento, dois caminhos psicológicos diferentes para esta operação: os conceitos espontâneos e os conceitos científicos:

Os conceitos cotidianos referem-se àqueles conceitos construídos a partir da observação, manipulação e vivência direta da criança. [...] Os conceitos científicos se relacionam àqueles eventos não diretamente acessíveis à observação ou ação imediata da criança: são os conceitos sistematizados, adquiridos nas interações escolarizadas (REGO, 1994, p. 77). 
A criança entra em contato com os conceitos porque eles estão presentes na linguagem, em contextos de atividade mediada. Assim, ao contrário do que o termo pode sugerir hoje, os conceitos espontâneos, não sistematizados ou cotidianos não surgem naturalmente ao longo da maturação do sujeito, nem são fruto apenas da razão abstrata, ou determinados pelo meio, mas aparecem pela mediação do outro, da linguagem, da cultura, em atividades concretas presentes cotidianamente no conjunto de interações em que a criança está inserida. Esses conceitos são utilizados prioritariamente em situações cotidianas; Vigotski (2010) percebeu uma dificuldade na criança em utilizá-los fora do seu contexto ou instrumentalizá-los como formas de pensamento abstrato. Normalmente são utilizados de forma inconsciente, ou seja, sem que haja plena consciência dos seus significados para além da atividade em que estão inseridos. Para o autor russo, aquilo que Piaget nas suas pesquisas considerava como propriedades do pensamento infantil egocêntrico ou interpretava como o estágio atual de desenvolvimento da criança, nada mais era do que os conceitos espontâneos que as crianças utilizavam. Assim, as particularidades do pensamento infantil não se dariam fundamentalmente pelas suas características autísticas, mas porque seus conceitos espontâneos estão relacionados mais intimamente à sua realidade mais próxima que a sistemas abstratos (VIGOTSKI, 2010).

Segundo a Teoria Histórico-Cultural, os conceitos científicos, sistematizados ou simplesmente não-espontâneos, são generalizações inseridas em um sistema de generalizações ainda maiores, organizados sistemática e hierarquicamente e cujo significado é convencionado social e historicamente. Geralmente não são apreendidos pela criança nas suas atividades cotidianas, cujo objetivo é orientado para alguma tarefa imediata (embora isso não seja uma regra). São apreendidos geralmente (mas não só) em um contexto de escolarização formal, onde a criança, orientada pela relação pedagógica, teria como desafio pensar o conceito de forma abstrata, para depois relacioná-lo à realidade concreta; ao mesmo tempo, seus conceitos espontâneos (ou cotidianos) seriam fundamentais para a compreensão dos conceitos sistematizados na escola, por exemplo. Ou seja, 
inicia-se na abstração, como atividade semiótica, significando os objetos do mundo. Assim, para Vigotski,

[...] a aprendizagem é, na idade escolar, o momento decisivo e determinante de todo o destino do desenvolvimento intelectual da criança, inclusive do desenvolvimento dos seus conceitos; baseia-se igualmente na suposição de que os conceitos científicos de tipo superior não podem surgir na cabeça da criança senão a partir de tipos de generalização elementares inferiores pré-existentes, nunca podendo inserir-se de fora da consciência da criança (VIGOTSKI, 2010, p. 262).

Para Vigotski, uma das características marcantes dos conceitos científicos seria a tomada de consciência dos sujeitos em relação aos seus processos mentais, instrumentalizando o conceito, verificando intelectualmente a sua aplicação ou não a determinados objetos e problematizando inclusive a validade ou não dos significados que o signo porta:

[...] o aluno escolar não só descobre a capacidade para a tomada de consciência e a arbitrariedade, mas também que o desenvolvimento dessa capacidade é o que constitui o conteúdo principal de toda a idade escolar (VIGOTSKI, 2010, p. 283).

Longe de os conceitos científicos ou sistematizados tomarem o lugar dos conceitos espontâneos, destruindo-os e eliminando o pensamento infantil, ambos se contaminariam e influenciariam o desenvolvimento, porém em sentidos opostos:

O crescimento contínuo desses níveis elevados no pensamento científico e o rápido crescimento no pensamento espontâneo mostram que o acúmulo de conhecimento leva invariavelmente ao aumento dos tipos de pensamento científico, o que, por sua vez, se manifesta no desenvolvimento do pensamento espontâneo e redunda na tese do papel prevalente da 
aprendizagem no desenvolvimento do aluno escolar (VIGOTSKI, 2010, p. 243).

A aquisição dos conceitos científicos, especialmente na relação pedagógica, elevaria qualitativamente a sistematização dos conceitos espontâneos, refinando-os. Por outro lado, o desenvolvimento dos conceitos espontâneos, a partir da abstração do conhecimento escolar, traria os conceitos científicos para o nível das impressões concretas, ampliando a dimensão semiótica de significados sistematizados. Dessa forma, o ensino teria um impacto substancial no desenvolvimento do sujeito.

Uma intervenção pedagógica de qualidade criaria, em tese, condições para a superação das debilidades dos dois tipos de conceitos, a saber: os conceitos espontâneos estariam muito presos à sua realidade imediata, generalizando de forma insuficiente os atributos abstraídos dos objetos; enquanto os conceitos científicos cairiam em um verbalismo excessivo, sem aplicação no mundo concreto. A aprendizagem de conceitos científicos, entretanto, não pode se dar em quaisquer bases. Se é verdade que não se pode aguardar a criança atingir necessariamente um determinado estágio do desenvolvimento para ensinar-Ihe, também não é possível ensinar qualquer coisa a um sujeito em qualquer etapa da sua vida, especialmente se a distância entre o conceito espontâneo que daria suporte ao conhecimento e o conceito científico que se pretende ensinar for muito grande:

Desse modo, o desenvolvimento dos conceitos científico e espontâneo segue caminhos dirigidos em sentido contrário, ambos os processos estão internamente e da maneira mais profunda inter-relacionados. O desenvolvimento do conceito espontâneo da criança deve atingir um determinado nível para que a criança possa apreender o conceito científico e tomar consciência dele. Em seus conceitos espontâneos, a criança deve atingir aquele limiar além do qual se torna possível a tomada de consciência (VIGOTSKI, 2010, p. 349). 
Para Vigotski, os conceitos espontâneos, presentes no pensamento infantil, não necessariamente se extinguem ao longo do desenvolvimento, mas é sobre eles que se constituem os conceitos científicos. É a partir daquilo que a criança já sabe, e que foi mediado de maneira informal pelos signos e instrumentos da cultura e pelas relações sociais, que se constituiriam os conceitos científicos de forma sistematizada, sobretudo na escola. Quanto mais significativa for a vivência cultural da criança, mais significativos também serão os conceitos sistematizados que a relação pedagógica pode lhe proporcionar.

Para Vigotski,

O conceito espontâneo, que passou de baixo para cima por uma longa história em seu desenvolvimento, abriu caminho para que o conceito científico continuasse a crescer de cima para baixo, uma vez que criou uma série de estruturas indispensáveis ao surgimento de propriedades inferiores e elementares do conceito. De igual maneira, o conceito científico, que percorreu certo trecho do seu caminho de cima para baixo, abriu caminho para o desenvolvimento dos conceitos espontâneos, preparando de antemão uma série de formações estruturais indispensáveis à apreensão das propriedades superiores do conceito (VIGOTSKI, 2010, p. 349).

Ainda assim, a aprendizagem não se resume apenas ao momento de aquisição de novos conceitos, nem ao momento em que os conceitos científicos e espontâneos se cruzam no desenvolvimento intelectual:

Quando uma palavra nova, ligada a um determinado significado, é apreendida pela criança, o seu desenvolvimento está apenas começando; no início ela é uma generalização do tipo mais elementar que, à medida que a criança se desenvolve, é substituída por generalizações de um tipo cada vez mais elevado, culminando o processo na formação dos verdadeiros conceitos (VIGOTSKI, 2010, p. 349). 
Por isso, ao longo do desenvolvimento do sujeito, ele não apenas apreende novos conceitos, mas altera os significados das palavras já apreendidas através das relações sociais, das mudanças culturais e históricas, nas sucessões de crises pelas quais se desenvolve ao longo da ontogênese. $O$ significado das palavras tem uma história na trajetória de vida do sujeito.

A mera exposição despropositada de conceitos no mundo escolar garante às vezes tão somente a apresentação de novas palavras, significando muito pouco para os alunos. A dificuldade está não em apresentar novas palavras ${ }^{7}$, mas em, de alguma forma, mediar o processo educativo de tal forma que as crianças comecem a pensar conscientemente os conceitos, sendo capazes de operações mentais como dissociar e associar atributos de objetos pela abstração, memorizar significados, imaginar generalizações ainda quando os objetos a que se referem os signos estejam ausentes.

A escola poderia promover, assim, um grande desenvolvimento de conceitos sistematizados. Sabe-se que o desenvolvimento não se dá concomitante ao planejamento do sistema escolar, nem tampouco o psiquismo dos alunos se divide em disciplinas como usualmente consta nas propostas curriculares. Mas o ensino de um conhecimento sistematizado, se bem conduzido, poderia intervir de maneira muito positiva sobre o desenvolvimento

\footnotetext{
7 desenvolvimento de um sujeito significa também internamente a reorganização das diferentes funções psicológicas superiores, no caso entre o pensamento por conceitos e outras funções como a linguagem. A formação de conceitos está intimamente ligada a esta outra função. Isso porque a palavra é o signo mediador através do qual a criança constituirá o pensamento conceitual. Consequentemente, embora a linguagem oral e a escrita sejam dimensões de uma mesma função superior (a linguagem), percorrem caminhos de desenvolvimento diferentes e constituem de forma diferente a formação de conceitos. A linguagem oral é mais fluída, mas rápida, utilizada por vezes de forma inconsciente, seus interlocutores estão sempre presentes. A linguagem escrita é meticulosa, detalhista, não admite desentendimentos; os interlocutores ou estão ausentes ou estão mais distanciados pelo espaço e pelo tempo. Ambas as modalidades da linguagem guardam, portanto, relações ora mais sistematizadas, ora mais espontâneas com os conceitos.
}

Neste sentido, embora não aprofundamos a reflexão sobre a linguagem para Vigotski, não desconsideramos a importância do tema. A aquisição da escrita como parte do desenvolvimento da linguagem, que se dá na grande maioria dos casos no contexto da instituição escolar, fornece um salto de qualidade na formação de conceitos não-espontâneos, na medida em que exige um uso mais consciente, intencional e arbitrário dos conceitos. 
do aluno, pois esse processo não se dá de forma fragmentada, e impacta sobre toda a dimensão intrapsicológica do sujeito.

Em suas pesquisas, a partir daquilo que chamou medida de generalidade, Vigotski buscou aferir qual a amplitude da propriedade de generalização utilizada pelas crianças nos experimentos. Concluiu, assim, que

\footnotetext{
$\mathrm{Na}$ medida em que se desenvolvem as relações de generalidade, amplia-se a independência do conceito em face da palavra, do sentido, da sua expressão, e surge uma liberdade cada vez maior das operações semânticas em si e em sua expressão verbal (VIGOTSKI, 2010, p. 368).
}

Ou seja, à medida que a criança adquire o pensamento conceitual como operação mental e se apropria da capacidade de generalização, passa inclusive a depender cada vez menos da palavra que medeia o significado e instrumentalizar cada vez mais os sistemas de significação elevando a abstração a um nível qualitativamente superior. A utilização dos conceitos científicos por parte dos sujeitos seria mais consciente que a dos conceitos espontâneos.

O processo de formação do pensamento por conceitos mostra-se assim dialético. Não se desenvolve a partir da maturação orgânica, embora necessite dela: não é tampouco uma qualidade inata do sujeito. Mas também não é determinado por fatores sociais, pois uma instituição como a escola não irá impor formas de pensamento ou ritmos de desenvolvimento. A aquisição do pensamento por conceitos, em especial os sistematizados oferecidos pela escola, só pode ocorrer se em diálogo com os conceitos espontâneos, constituídos no psiquismo das crianças a partir de elementos da cultura. Mesmo assim, ambas as aquisições (de conceitos espontâneos e científicos) configuram-se de maneira particular e idiossincrática em cada indivíduo.

No entanto, Oliveira (2009) faz algumas ponderações sobre a maneira como Vigotski considerava os diversos tipos de conceitos: 
As proposições vygotskianas a respeito dos conceitos genuínos em oposição aos complexos, aos pseudoconceitos e aos conceitos potenciais, e a respeito dos conceitos científicos em contraposição aos conceitos cotidianos, parecem tornar sua teoria a respeito da estrutura conceitual mais relevante à compreensão de um tipo específico de conceitos e não necessariamente aplicável a esferas fora da ciência. Isso pode ser interpretado como uma possível limitação da teoria, no sentido de que os conceitos não científicos não seriam adequadamente compreendidos e, ao mesmo tempo, seriam avaliados como estando afastados do único tipo verdadeiro ou genuíno de conceitos, os quais constituiriam um modelo para a organização conceitual mais avançada (OLIVEIRA, 2009, p. 288-289).

Há que se relativizar, portanto, a relação entre os conceitos não científicos e os científicos e a suposta hierarquia que existiria entre formas de pensamento típicas da ciência e da escolarização e formas de pensar advindas de práticas societárias não ligadas à escrita, ao conhecimento sistematizado científico. Para Santos e Mortmer (2002), seria questionável inclusive a eficácia da utilização do pensamento científico como resolução de todas as demandas da vida social:

Os conceitos cotidianos continuarão a ter peso na maioria das decisões que tomamos na vida cotidiana, independente do nosso conhecimento de alternativas mais científicas, pois, muitas vezes, essas são inúteis para a solução desses problemas. O reconhecimento desses limites evita a ilusão, que no fundo é cientificista, de que a ciência poderá, num futuro, informar todas as nossas decisões (SANTOS; MORTMER, 2002, p. 14).

De todo o modo, para a Teoria Histórico-Cultural, considera-se que são as práticas sociais nas quais o sujeito está inserido, assim como a apropriação dos instrumentos técnicos e semióticos, que constituem as transformações do desenvolvimento psicológico dos indivíduos, incluído aí o pensamento por conceitos. No caso das sociedades contemporâneas, o pensamento conceitual parece ser constantemente demandado: 
As principais características do modo de funcionamento cognitivo associado a práticas culturais predominantes em sociedades urbanas, escolarizadas, industrializadas, burocratizadas e caracterizadas por desenvolvimento científico e tecnológico, parecem ser a possibilidade de pensamento descontextualizado, não referido à experiência individual imediata, e o domínio consciente, pelo sujeito, de seus próprios processos cognitivos (procedimentos metacognitivos) (OLIVEIRA, 2009, p. 177).

Um pensamento mais ligado ao contexto imediato dos sujeitos não deixaria necessariamente de ser conceitual, mas apresentaria elementos conceituais mais fragmentados. O sujeito nesse caso, ao não utilizar os conceitos de maneira consciente, não seria inteiramente capaz de reconhecer o processo cognitivo que o levou a chegar a determinada conclusão, frequentemente utilizando determinadas teorias sem se dar conta disso. No pensamento conceitual 0 indivíduo poderia inclusive manipular teorias, instrumentalizando generalizações que orientariam a reflexão sobre situações concretas. A utilização consciente de conceitos não apenas seria aplicável de maneira descontextualizada, como também se relacionaria a outros conceitos. Assim, o pensamento conceitual também permitiria operações metacognitivas, ou seja, que o indivíduo tivesse consciência do percurso do seu próprio pensamento, podendo inclusive explicá-lo publicamente a outrem.

Em um estudo em que comparava as respostas de adultos pouco escolarizados da EJA e alunos no curso de Licenciatura da Universidade de São Paulo, Oliveira (2009) percebeu que não se pode afirmar com certeza que os primeiros respondem apenas a partir da sua realidade concreta e os segundos a partir de generalizações conceituais por terem tido mais anos de escolarização. Ao contrário, em sua pesquisa, muitos adultos pouco escolarizados demonstraram inclusive elementos de atitudes metacognitivas que os estudantes da USP não demonstraram, como podemos ver na resposta dada a seguir: "'Se tivesse pensado nisso antes, teria me preparado' - S., 
classe de alfabetização; 'Você me pegou de surpresa, nunca pensei nisso antes' - M., classe de alfabetização" (Oliveira, 2009, p. 192).

Contraditoriamente ao que comumente é dito, sujeitos mais escolarizados não necessariamente operam seus pensamentos sempre ou em qualquer contexto com conceitos abstratos, com características isoladas e generalizáveis. Ao contrário, a utilização de generalizações, abstrações e elementos metacognitivos no pensamento parecem derivar mais de como se dão as relações interpessoais em que se dá a interação (na escola, no sindicato, em uma pesquisa que demande testes psicológicos, etc.). Assim, as redes e ligações entre conceitos supostamente presentes no pensamento de um sujeito escolarizado individualmente, seriam bem menos importantes que a mediação, pelo outro, no processo inter e intrapsicológico extremamente complexo da formação do pensamento conceitual. Estaríamos explorando não uma maneira de pensar presente ou não em um indivíduo, mas investigando o processo de construção, social e psicológico, do pensamento dos sujeitos.

\subsubsection{Aprendizagem e desenvolvimento}

Muito se tem discutido na Psicologia sobre qual a relação entre aprendizagem e desenvolvimento, e se há uma relação de determinação entre uma e outra. Na perspectiva da Teoria Histórico-Cultural, ao longo do desenvolvimento do sujeito, essas duas dimensões se entrecruzariam e se influenciariam mutuamente. ${ }^{8}$ Assim, a gênese do desenvolvimento e suas funções psicológicas superiores como o pensamento conceitual estaria na relação do sujeito com a cultura, que forneceria o horizonte do desenvolvimento cognitivo dos indivíduos:

\footnotetext{
${ }^{8}$ Entre o fim do século XIX e início do século XX, alguns autores defendiam que o desenvolvimento da criança é fruto da maturação do organismo, outros identificavam desenvolvimento e aprendizagem como praticamente o mesmo processo; outros ainda sintetizavam elementos das duas teses, defendendo um conjunto de teorias que desejavam acelerar externamente 0 desenvolvimento dos alunos (VIGOYSKI, 2010).
} 


\begin{abstract}
Vygotsky não ignora as definições biológicas da espécie humana; no entanto, atribui uma enorme importância à dimensão social, que fornece instrumentos e símbolos (assim como todos os elementos presentes no ambiente humano impregnados de significados) que medeiam a relação do indivíduo com o mundo, e que acabam por fornecer também seus mecanismos psicológicos e formas de agir nesse mundo. O aprendizado é considerado, assim, um aspecto necessário e fundamental no processo de desenvolvimento das funções psicológicas superiores (REGO, 1994, p. 70).
\end{abstract}

Para Vigotski, operações mentais complexas requerem uma mediação com signos (palavras), cuja ação é reversa "isto é, age sobre o indivíduo e não sobre o ambiente" (VIGOTSKI, 2000, p. 53). A relação do indivíduo com o mundo deixa de ser direta, para na verdade ser uma relação mediada pelos signos. Assim, os processos psicológicos superiores, como o pensamento conceitual, além de serem muito mais complexos do que meramente um prolongamento de funções orgânicas, permitem ao sujeito controlar conscientemente o próprio comportamento.

Para crianças pequenas, muito marcadas pelas experiências mais imediatas, o desenvolvimento das funções psicológicas superiores, particularmente o pensamento, está apenas no início da sua relação com a cultura:

O conteúdo do ato de pensar da criança, quando da definição de tais conceitos, é determinado não tanto pela estrutura lógica do conceito em si, como o é pelas suas lembranças concretas. Quanto a seu caráter, ele é sincrético e reflete o fato de pensar da criança depender, antes de mais nada, de sua memória (VIGOTSKI, 2000, p. 66).

Assim, crianças tendem a pensar conceitos não com a suas características de abstração e generalização, mas a partir das suas memórias sobre determinadas relações concretas que fazem com objetos. As palavras 
não estão relacionadas exclusivamente a significados dados socialmente, mas a elementos visuais relacionados entre si. Ao fim da infância, aparentemente haveria uma tendência a uma reorganização das funções superiores, de modo que "Para as crianças, pensar significa lembrar; no entanto, para o adolescente, lembrar significa pensar" (VIGOTSKI, 2000, p. 67), ou seja, o pensamento dirigido passaria a orientar a atividade mental. Em geral, na adolescência, as ideias deixariam de representar classes de objetos com quem o sujeito teve alguma relação concreta, e sim conceitos abstratos a partir dos quais se pensar a realidade.

Segundo o autor, embora instrumento e signo não sejam em absoluto idênticos, pode-se afirmar que os últimos cumprem um importante papel de instrumento psicológico. Isso porque ambos são mediadores das atividades humanas. O signo, no entanto, tem a particularidade de orientar a atividade interna do indivíduo, que através da mediação de práticas e saberes culturais, se apropria delas, internalizando-as psiquicamente.

Para Vigotski,

Isso se aplica igualmente para a atenção voluntária, para a memória lógica e para a formação de conceitos. Todas as funções superiores originam-se das relações reais entre indivíduos humanos (VIGOTSKI, 2000, p. 75).

Dessa forma, um processo que é social e interpessoal, como a utilização de significados e sentidos, pode ser internalizado depois de longo processo, constituindo pensamento conceitual: "A internalização de formas culturais de comportamento envolve a reconstrução da atividade psicológica tendo como base as operações com signos" (VIGOTSKI, 2000, p. 75).

Essa passagem entre práticas societárias e formas de pensamento se daria de maneira sempre dialética entre essas dimensões. Para Chaiklin (2011), Vigotski considerava a imitação de práticas sociais não como a mera 
reprodução mecânica para alguma tarefa, mas sim como a realização de tarefas em conjunto com parceiros capazes de ajudar o sujeito. Sua estrutura mental já estaria desenvolvida a ponto de realizá-la de forma cooperativa, pois as funções psicológicas, embora não plenamente desenvolvidas, já lhe orientariam a atividade.

Assim, ao contrário dos animais que ao imitarem se limitam às próprias possibilidades intelectuais, Vigotski afirma que

$\mathrm{Na}$ criança, ao contrário, o desenvolvimento decorrente da colaboração via imitação, que é a fonte do surgimento de todas as propriedades especificamente humanas da consciência, 0 desenvolvimento decorrente da aprendizagem é o ponto fundamental. [...] A imitação, se concebida em sentido amplo, é a forma principal em que se realiza a influência da aprendizagem sobre o desenvolvimento (VIGOTSKI, 2010, p. 331).

O desenvolvimento não apenas pode ser influenciado pela interação de um parceiro na cultura, mas ocorre necessariamente pela mediação do outro. $\mathrm{E}$ a escola é uma instituição cultural do mundo contemporâneo privilegiada para isso. Não se trata de aguardar a criança completar uma etapa como condição necessária para que aprenda, mas buscar uma interação que medeie com qualidade o desenvolvimento de funções em maturação. Elas são resultado da colaboração com o outro, particularmente em um contexto educativo, e serão as funções desenvolvidas de amanhã. Ao longo desse processo, elas são reordenadas como um todo. Portanto, a aprendizagem antecederia e interferiria substancialmente no desenvolvimento: "A pedagogia deve orientar-se não pelo ontem, mas pelo amanhã do desenvolvimento da criança." (VIGOTSKI, 2010, p. 333).

Segundo Chaiklin (2011), a interpretação mais comumente dada hoje ao conceito de zona de desenvolvimento próxima é influenciada por três equívocos: acredita-se que a ideia de zona de desenvolvimento proximal municie os educadores a trabalhar qualquer conteúdo ou tarefa com os alunos; 
a cooperação necessariamente deve vir do parceiro mais experiente na cultura, considerando o papel do professor ou o adulto como agente exclusivo de avanços no desenvolvimento; a aprendizagem necessariamente seria uma atividade intelectual prazerosa, por estimular funções já em maturação.

$\mathrm{Na}$ verdade, a Zona de Desenvolvimento Proximal seria um conceito vigotskiano explicativo que auxiliaria a compreensão das passagens entre os diferentes estágios do desenvolvimento, dentro de relações concretas. Além disso, quando se fala aqui em estágio ou idade, não se está referindo ao período da maturação em que se encontra um indivíduo, e sim de que forma as relações sociais e suas mediações nessa situação o auxiliam em funções que ainda estão maturação (CHAIKLIN, 2011).

Assim, a simultaneidade do processo intrapsicológico de desenvolvimento de funções em maturação e do processo interpsicológico de interação social pela cultura poderiam ser sintetizados da seguinte forma:

Pode-se afirmar que a zona objetiva de desenvolvimento próximo para cada período é normativa, na medida em que reflete as demandas e expectativas institucionalizadas que se desenvolveram historicamente em uma particular tradição societária de prática (CHAIKLIN, 2011, p. 666).

Cada sujeito em particular tem a sua própria maneira subjetiva de vivenciar a sua relação com as expectativas institucionalizadas, a sua própria forma de internalizar estas relações sociais tornado-as funções psicológicas. Ao mesmo tempo, a zona de desenvolvimento próximo não é um processo exclusivamente subjetivo. Para Chaiklin, poder-se-ia afirmar que cada sociedade cria a sua zona de desenvolvimento próxima, pois histórica e culturalmente suas instituições educam os indivíduos de suas sociedades para desenvolverem funções psicológicas de uma determinada maneira.

De qualquer forma, no atual momento histórico, convencionou-se que a escolarização é um processo de desenvolvimento importante na vida dos 
sujeitos, para que se apropriem adequadamente da sua própria cultura, do conhecimento acumulado ao longo da história, de formas de pensar com conceitos sistematizados. O estudo da Zona de Desenvolvimento Imediato/Proximal é importante para a compreensão do desenvolvimento humano, pois "Um maior número de funções em maturação dá a uma criança melhores oportunidades de se beneficiar do ensino escolar" (CHAIKLIN, 2011, p. 670), e por que não de uma maior quantidade e qualidade de conceitos sistematizados.

Outra maneira de pensar a relação entre práticas sociais interpsicológicas e desenvolvimento intrapsicológico seria pensar as práticas sociais como discursivas, constitutivas da consciência. Em certos momentos das aulas é possível perceber falas comuns, quando tanto professor quanto alunos conseguem estabelecer uma comunicação eficiente e falam ao mesmo tempo sobre determinados temas, constituindo o chamado "conhecimento compartilhado" (EDWARDS; MERCER, 1988). Em outros momentos, além das falas, parte do discurso são recursos como gestos, mímicas, pausas, expressões, por parte do professor, mas também dos alunos, que auxiliam na comunicação e na construção de um conhecimento comum.

Ao longo do processo de desenvolvimento, a forma como se dá a mediação da cultura ao indivíduo é de suma importância para que ele internalize, da sua própria maneira, práticas societárias que se converterão, no plano psicológico, em funções psicológicas superiores. No caso do pensamento conceitual, é a partir da mediação de diversas formas de significação social, especialmente (mas não só) na escola, que o indivíduo poderá constituir pensamento conceitual sistematizado, e utilizá-lo de maneira descontextualizada, intencional e consciente.

O contexto de uma prática sócio-discursiva possui uma poderosa dimensão mental. Isso porque, apesar de haver uma série de mediações do ambiente físico, é no plano psicológico que o "conhecimento compartilhado" possibilita que os participantes se entendam, compreendam o que está em jogo, e se esforcem para viabilizar as atividades em sala de aula, por exemplo. 
Se o processo educacional em determinada turma de alunos é satisfatório, é porque o contexto mental provavelmente foi construído socialmente de maneira mais eficiente, tornando professor e alunos cúmplices de um mesmo discurso educacional. Ainda assim, o deslocamento de ideias descontextualizadas, próprias do que possibilitaria a linguagem, pode se dar de maneira problemática, uma vez que os alunos parecem utilizar a linguagem escolar para discutir apenas as atividades que se realiza em sala de aula.

As orientações do professor, nas ações ao longo das aulas, são fundamentais para criar um repertório comum, que possa mediar um conhecimento compartilhado. Em outros momentos, quando o professor orienta que os alunos se lembrem de algo, que se recordem de algum conceito ou alguma ação prática, está intervindo, como afirmava Vigotski (2000), na Zona de Desenvolvimento Proximal, construindo um conhecimento compartilhado entre os alunos e promovendo uma aprendizagem que se antecipe ao desenvolvimento.

\subsubsection{Do inter ao intrapsicológico}

Como comentado anteriormente, para a perspectiva Histórico-Cultural, o desenvolvimento cognitivo dos sujeitos se dá sobre uma base orgânica (particularmente a plasticidade do cérebro), mas sua gênese é fundamentalmente orientada pela cultura. Dessa maneira, toda função psicológica superior inicia nas relações sociais, historicamente constituídas, para só então ser internalizada pelo sujeito; no caso do pensamento conceitual vimos como a linguagem e seus signos carregam significações e sentidos, que são o início do pensamento conceitual.

Para Oliveira (2009), há três questões sobre o desenvolvimento, a partir da perspectiva da Teoria Histórico Cultural. A primeira é relacionada ao que ela chama de "libertação dos seres humanos do contexto perceptual imediato" (OLIVEIRA, 2009, p. 240). Ao longo da filogênese, a humanidade teria 
conquistado, pelo papel da atividade, do uso de instrumentos e de signos, a capacidade psicológica de pensar para além do seu cotidiano, dada a complexidade das formas de sociabilidade historicamente constituídas. $\mathrm{O}$ pensamento conceitual seria, historicamente, anterior inclusive à escolarização como é posta nas sociedades contemporâneas, pois estaria intimamente ligado ao desenvolvimento histórico da linguagem. Assim, o pensamento conceitual, (particularmente o conceito cotidiano), não foi um prolongamento da evolução ou de nenhuma causa metafísica, mas uma conquista da humanidade mediada pela cultura e pelas necessidades humanas ligadas ao trabalho.

Nos últimos séculos, porém, o avanço da escolarização trouxe a possibilidade de uma maior sistematização, organização e compartilhamento de generalizações e atividades caracterizadas pela metacognição. A escolarização promoveria 0 contato do sujeito a conhecimentos não diretamente relacionados às suas atividades e conceitos cotidianos, transformando-os e ressignificando-os. A possível separação do pensamento do indivíduo de seu contexto social mais imediato teria se dado na filogênese com o surgimento da fala, com a imersão do sujeito em contextos sóciohistóricos específicos, e finalmente com a escolarização (que propiciaria ter consciência dos conceitos utilizados, desenvolvendo processos mentais metacognitivos) (OLIVEIRA, 2009).

$\mathrm{Na}$ perspectiva Histórico-Cultural há que se observar, em segundo lugar, também que os conceitos "não são entidades isoladas, mas elementos de um sistema complexo de inter-relações" (OLIVEIRA, 2009, p. 244). No pensamento do indivíduo, o conceito jamais se encontra isolado, mas sempre em relação a outros, constituindo uma rede articulada. Teorias científicas, senso-comum, construções advindas de diversas instituições (movimento sociais, culturais, igrejas, etc.) são o todo a partir do qual o sujeito instrumentaliza os conceitos para pensar sua realidade. Os diversos significados e sentidos de uma palavra estão em constante transformação, tanto na sociedade quanto no desenvolvimento cognitivo do sujeito. 
Particularmente importante para esse processo seria a escolarização, por trabalhar deliberadamente com conceitos cuja aplicação nem sempre é imediata para os alunos. As formas de pensamento demandadas pela escola a princípio se orientariam pela estruturação metateórica dos objetos do conhecimento, nas várias disciplinas escolares. Mesmo assim, não se pode dizer de forma alguma que a constituição de pensamento por conceitos científicos só é possível na escola; inúmeros são os casos de indivíduos que encontram a mediação para essa forma de pensar em outros espaços ou instituições. Mesmo assim, quanto maior for a distância entre o cotidiano do sujeito e o tipo de pensamento sistematizado, maior a necessidade de uma escola de qualidade que oriente as práticas pedagógicas na direção de conhecimentos sistematizados.

A terceira questão levantada pela autora sobre o pensamento conceitual, é que a partir das reflexões de Vigotski e demais autores que tem se debruçado sobre suas teorias, "os conceitos não são entidades estáveis, 'possuídas' pelo sujeito, mas sim produtos de processos de construção conjunta de significações" (OLIVEIRA, 2009, p. 250). A construção coletiva dos conceitos faz com que essa tarefa jamais esteja terminada, inserindo o sujeito em um conjunto de interações e construção de conhecimentos que estão sempre em constante transformação. Pode-se dizer que a constituição de pensamento conceitual, ao iniciar-se no plano social, não pode ser controlada ou prevista em seu caminho para o plano psicológico. No entanto, é importante ressaltar que historicamente, alguns conceitos ganham mais legitimidade que outros a partir das relações de poder institucionais. E na escola, como não poderia deixar de ser, há também saberes hegemônicos, particularmente os sistematizados e científicos, que são (erroneamente) vistos como "verdadeiros". Assim, tanto o significado (zona mais "estável" dos conceitos) quanto os sentidos (mais "flexíveis" em relação ao objeto referente) são construídos de acordo com o contexto sócio-histórico a que são submetidos. No plano individual, não é secundário o aspecto afetivo do pensamento conceitual, pois as motivações pessoais para determinada reflexão não estão dissociadas de saberes inclusive considerados "acadêmicos". Não é incomum 
encontrar no mesmo indivíduo diversas formas de pensamento (científicas e não científicas).

Assim,

\begin{abstract}
A organização conceitual, muito mais que uma teoria completa e estável, parece ser, portanto, um conjunto flexível de significados, aberto a uma reestruturação constante com base em situações interpessoais que promovem reflexão. Essa constatação tem importantes implicações para a pesquisa em psicologia cognitiva: o processo mesmo de construção coletiva do significado seria objeto mais relevante para a compreensão dos mecanismo cognitivos do que um suposto "estado", ainda que reconhecido como temporário, de organização conceitual. As noções de transformação, de densa interação intelectual e de promoção de verdadeira reflexão tornar-se-iam essenciais para a compreensão do funcionamento cognitivo humano, tornando-o mais próximo da ideia de desenvolvimento cognitivo (OLIVEIRA, 2009, p. 295).
\end{abstract}

Portanto, na Teoria Histórico-Cultural, nota-se a importância das interações sociais, no desenvolvimento dos alunos, como mediadoras da constituição das funções psicológicas superiores, cujo impacto no plano intrapsicológico se daria, por exemplo, pela conquista do pensamento, seja ele complexo ou conceitual, cotidiano ou sistematizado.

Este processo se daria, contudo, não pela negação das formas do pensamento por conceitos cotidianos, nem pela mera destruição das formas de pensamento infantil, como o pensamento sincrético ou por complexos. Pelo contrário, todos estes modos de pensar e sentir deveriam ser estimulados e desenvolvidos, pois sem eles o pensamento, especialmente por conceitos sistematizados, teria dificuldades de se enraizar e se estruturar na atividade mental da criança.

Não seria exagero afirmar, portanto, que é a partir das experiências e também da criatividade e imaginação dos sujeitos (SMOLKA, 2004) que se desenvolveria o pensamento por conceitos, ao longo da ontogênese do sujeito. Afirma Vigotski que 
Os nossos experimentos nos levam a uma conclusão essencialmente distinta. Mostram como das imagens e vínculos sincréticos, do pensamento por complexos, dos conceitos potenciais e com base no uso da palavra como meio de formação de conceito surge a estrutura significativa original que podemos denominar de conceito na verdadeira acepção desta palavra (VIGOTSKI, 2010, p. 239).

Para o autor, muito importante também nesse processo seria a linguagem, que como mediador de narrativas e visões de mundo, possibilitaria à imaginação que o pensamento tome consciência de realidades com as quais o sujeito não entrou em contato de forma imediata. Ao ouvir, escutar ou observar uma história, a linguagem permitiria à criança ou ao adulto reconstruir mentalmente à sua própria maneira, narrativas fantásticas do campo das artes e da literatura ou conceitos sistematizados que não estão ao seu alcance individual, como diferentes territórios, outros períodos históricos, sistemas solares, etc.

Para Góes e Cruz (2006), Vigotski teria valorizado sobremaneira a linguagem, pois através dela os sentidos e os significados sociais são apresentados para a criança e podem por ela ser reelaborados. Dessa forma,

[...] não há conceito sem atividade semiótica verbal. É esta que possibilita modos de conhecer próprios do homem. Embora outros signos - que não os verbais - possam mediar 0 conhecimento humano, ele (Vigotski) vincula explicitamente 0 conceito à palavra (GÓES; CRUZ, 2006, p. 33).

Apesar da diferença de significados entre a criança e o adulto, é na interação verbal que se realiza um acordo sobre os referentes, garantindo a comunicação. Mesmo assim, as operações psíquicas que realizam são fundamentalmente diferentes. Verifica-se isso quando um adulto questiona uma criança e ela nem sempre é capaz de precisar ou explicar o que está querendo 
dizer. A palavra não é o fim, mas um meio culturalmente privilegiado de mediação social: "a generalização é concebida como o fundamento e a essência da palavra." (GÓES; CRUZ, 2006, p. 36).

Consequentemente, para as autoras, deve-se também repensar a relação entre sentido e significado: "Por vezes, ao discutir a fala externa e a fala interna, estabelece-se contraposições excessivas entre o ilimitado dos sentidos e a extrema estabilidade dos significados." (Ibidem, p. 38).

Haveria, portanto, uma dialética entre sentido e significado, constituído pela possibilidade de eventos em um dado contexto sócio-histórico, próprio da dinâmica da linguagem. Ao longo da história, a riqueza de significações para as palavras, abriria as portas para o desenvolvimento das funções psicológicas superiores como o pensamento conceitual.

Segundo as autoras (Ibidem), já na ontogênese, a palavra tem uma história de desenvolvimento de diferentes significações para o sujeito ao longo da vida, pois a formação do pensamento conceitual não é estável. Desenvolvese sem excluir outras formas de pensamento e seus processos estariam menos relacionados à lógica formal, e mais próximos a uma lógica dialética.

Apesar de normalmente o papel socialmente atribuído à escola seja o de ensinar esta forma específica de pensar, Góes e Cruz (2006) chegam à conclusão de que como o pensamento está sendo mediado socialmente por um amplo leque de significações, talvez tenhamos que repensar inclusive 0 papel da educação:

De fato, ensinar conhecimentos sistematizados e culturalmente valorizados é compromisso da escola. Contudo, quando agregamos a noção de sentido, esse compromisso se expande, abrangendo diversas formas de trabalho sobre o campo da significação (GÓES; CRUZ, 2006, p. 41). 
Ao pensar o desenvolvimento da função psicológica superior do pensamento, em um mesmo sistema psíquico com outras funções como a linguagem e a imaginação, considera-se a possibilidade de que não necessariamente o caminho do pensamento por conceitos se dá na direção da estabilidade dos sentidos das palavras. Pensar seria necessariamente (re)criar sentidos, e não apenas reproduzir significados.

A criação estaria intimamente relacionada à formação de conceitos, uma vez que as habilidades necessárias para esse pensamento, como a abstração, romperiam com as impressões imediatas do sujeito com a sua realidade mais imediata e exigiriam grande esforço imaginativo: "Por fim, o último momento do trabalho preliminar da imaginação é a combinação de imagens individuais, sua organização num sistema, a construção de um quadro complexo." (VIGOTSKI, 2004, p. 39).

Embora a aquisição do pensamento conceitual, em especial dos conceitos científicos e sistematizados, sem dúvida represente uma grande conquista psicológica para o sujeito, ela só foi possível por causa da atividade psíquica: "Vemos que o exagero, assim como na imaginação, em geral, é necessário tanto na arte como na ciência. Não fosse essa capacidade (...), a humanidade não teria criado a astronomia, a geologia, a física." (GÓES; CRUZ, op. cit., p. 39) $\mathrm{Na}$ organização dos dados colhidos pelo cientista, em contraposição às teorias que o sustentam, é necessária no campo das ciências uma enorme capacidade imaginativa, de forma que o pensamento conceitual não só não elimina uma forma de pensar e sentir que se constituiu na infância, como necessita inteiramente dessa mesma atividade mental para a composição de sistemas complexos de conceitos sistematizados.

Por fim, alguns comentários sobre a Teoria Histórico-Cultural e a formação do pensamento conceitual. As formulações teóricas de Vigotski acerca do processo de formação do pensamento por conceitos são instigantes, não apenas pela enorme contribuição no campo da psicologia genética, mas, sobretudo, pelo estímulo a novas pesquisas e reflexões sobre o desenvolvimento cultural dos sujeitos, especialmente num contexto escolar. $\mathrm{O}$ 
debate acerca das suas proposições se reflete na produção acadêmica até os dias atuais.

Antes de Vigotski, muitos autores se aventuraram a pensar a formação de conceitos; como todo campo do conhecimento, a Psicologia está inserida e localizada em determinados contextos históricos que abrem possibilidades e impõem limites. Apesar de ter como objeto de estudo o desenvolvimento humano, que tradicionalmente era visto como universal no início do século XX, possui ela mesma como campo do conhecimento uma historicidade intrínseca que a colocava em uma determinada perspectiva racionalista, analisando pouco os processos de desenvolvimento em uma dialética entre a maturação do organismo e a cultura.

A evolução da espécie humana (filogênese), juntamente com a maturação do organismo ao longo da história de vida dos sujeitos (ontogênese), são elementos importantes do desenvolvimento humano. É nessa base fisiológica que ocorrerão os processos cognitivos originados na história, na cultura e na sociedade. Entretanto, ao longo da vida do sujeito, a imersão na cultura propicia, a partir da mediação do outro, dos signos e dos instrumentos, a constituição de determinadas formas de pensar. Embora Vigotski de fato descreva uma sequência na história do desenvolvimento dos sujeitos, do pensamento sincrético ao conceitual, passando pelo pensamento por complexos, seria reduzir a sua teoria chamá-lo de "etapista". Na realidade, essas etapas não seriam fixas ou "ahistóricas", mas seriam constituídas de acordo com as vivências e experiências dos sujeitos, sem que necessariamente formas consideradas infantis de pensamento estejam condenadas ao desaparecimento. Mesmo assim, não deixa de ser uma conquista o pensamento conceitual na adolescência, pois nessa fase da vida 0 sujeito pela primeira vez passa a pensar a realidade a partir das formas de significação próprias do mundo adulto.

O pensamento por conceitos, cujo mediador é o signo da palavra, seria capaz de generalizar, discriminar e sintetizar elementos dos objetos da vida social, tornando viáveis as diversas organizações sociais. Os conceitos 
utilizados especialmente em situações cotidianas, voltadas para determinadas tarefas, seriam os conceitos espontâneos, enquanto aqueles utilizados em um contexto educativo, capazes a partir de um sistema abstrato de generalizações pensar a realidade, seriam os científicos, sistematizados ou não-espontâneos. Ao longo do desenvolvimento do sujeito, em sociedades escolarizadas, o desenvolvimento de uns e outros se encontraria e se influenciaria mutuamente. Para Vigotski, quando um conceito é apreendido pela criança, esse processo não termina, mas a história das significações desse signo no pensamento da criança está apenas começando.

A mediação de um parceiro na cultura propiciaria ao sujeito um desenvolvimento em determinadas funções ou procedimentos que ele sozinho ainda não seria capaz de sustentar. A passagem de uma "etapa" para outra é justamente esse momento de "crise", quando a partir de uma estrutura o sujeito reorganiza suas funções psicológicas superiores em direção a uma nova configuração. À medida que se desenvolve, a partir das instituições sociais e culturais às quais a criança está inserida, surgem novas experiências e vivências. A distância entre $\mathrm{o}$ atual estágio de desenvolvimento e seu desenvolvimento futuro, dado por aquilo que the é exigido socialmente, corresponde à zona de desenvolvimento proximal, próxima, potencial ou imediato. O horizonte do desenvolvimento do sujeito é dado pelas tradições societárias e pela cultura, que orientam o futuro das funções psicológicas superiores em cada indivíduo.

Para Vigotski, as funções superiores compõe um sistema dinâmico, onde cultura e desenvolvimento psicológico se influenciam mutuamente. $O$ pensamento conceitual libertaria $o$ indivíduo da sua realidade concreta, constituindo a sua consciência em uma rede conceitual constituída na cultura, que possibilitaria uma constante negociação de sentidos e significados. Nesse sentido, o desenvolvimento do pensamento conceitual, longe de representar a aquisição de uma estrutura estável de pensamento científico, implicaria, ao contrário, grande capacidade criadora e transformadora. 
Ao analisarmos a cultura como constitutiva dos processos psíquicos, bem como a formação de funções psicológicas superiores como a formação do pensamento conceitual, abre-se um amplo campo de discussões teóricas cujo horizonte ultrapassa os limites deste trabalho. A Teoria Histórico-Cultural poderia contribuir com o debate acerca dos dilemas da educação com a sua reflexão profunda e inspiradora. Com a palavra, Vigotski:

Nessa fase, em suas operações mentais a criança esbarra constantemente na inadaptabilidade do seu pensamento ao pensamento dos adultos, sofre constantes derrotas e fracassos, que revelam a inconsistência de sua lógica, bate constantemente com a cabeça na parede e os galos que recebe são, segundo sábia expressão de Rousseau, os seus melhores mestres, porque são constantes e abrem perante a criança o sésamo dos conceitos conscientizados e arbitrários (VIGOTSKI, 2010, p. 277). 


\section{Métodos e análises}

As análises das minúcias das relações intersubjetivas, em um contexto de sala de aula, foram realizadas a partir de um diálogo entre a Etnografia e a Teoria Histórico-Cultural, como se verá a seguir. Também utilizamos as contribuições de Bakhtin para o estudo das práticas sócio-discursivas em sala de aula e da Psicologia Discursiva para investigar a ideologia da educação e a diferença entre os rituais e os princípios das práticas escolares. Outra discussão que traremos neste capítulo será sobre a chamada "consciência histórica", a fim de compreender as interações que analisaremos adiante, em quatro episódios observados em sala de aula.

\subsection{A pesquisa etnográfica em sala de aula}

O estudo e a pesquisa sobre as relações concretas entre sujeitos em sala de aula e a dimensão semiótica das práticas discursivas no espaço escolar demandam metodologias de pesquisa que nos forneçam instrumentos de análise para essas realidades específicas. O estudo de campo e a sistematização do material empírico devem se dar a partir de bases teóricometodológicas que nos possibilitem uma análise minuciosa nas interações entre alunos da EJA nas aulas de História, e ao mesmo tempo, relacionarmos essa realidade específica com contextos mais amplos. As pesquisas qualitativas e etnográficas na educação nos parecem, assim, contribuir bastante para um olhar mais aprofundado diante da complexidade das relações entre sujeitos no espaço escolar.

Para Rockwell (1986), a etnografia tem a sua origem a partir da segunda metade do século XIX, no contexto do neocolonialismo das potências capitalistas sobre povos da América Latina, África e Ásia. Nesse momento, constituía-se a antropologia funcionalista, que se contrapunham ao evolucionismo e ao positivismo da época, perspectivas que hierarquizavam as sociedades entre as supostamente "primitivas" e "civilizadas", e justificavam o 
domínio imperialista pela noção de "progresso". Ela teria propiciado avanços como: a investigação dos significados que os sujeitos atribuíam às suas próprias práticas; estudos que explicavam práticas sociais não ocidentais, mas que eram igualmente "funcionais"; observação de diversos problemas da vida cotidiana. Contudo, para a autora, as pesquisas antropológicas realizadas em fins do século XIX e nas primeiras décadas do século XX não necessariamente romperam com uma certa noção de superioridade das sociedades europeias.

A partir daí, antropologia passou a ser utilizada não apenas para pesquisar realidades consideradas "exóticas" ou "primitivas", mas também para se debruçar sobre a própria sociedade ocidental. Segundo a autora, passou-se a documentar também fenômenos familiares aos ocidentais, mas que permaneciam bastante desconhecidos para a antropologia. Dessa maneira,

\begin{abstract}
A etnografia proporcionou uma volta à observação da interação social em situações "naturais", um acesso a fenômenos nãodocumentados e difíceis de serem incorporados às exigências do levantamento e do laboratório. [...] Armados com instrumentos e conceitos forjados nas ilhas, os etnógrafos entram no campo das "sociedades complexas" através do estudo de situações peculiares à vida cotidiana das ruas, bairros e comunidades, hospícios, cárceres, tribunais, clínicas e escolas. Ao desenvolver-se nestes campos do domínio clássico da sociologia a etnografia propõe uma nova visão, definindo novos objetos de estudo e elaborando conceitos pertencentes à escala estudada (ROCKWELL. In: EZPELETA; ROCKWELL,1986, p. 38).
\end{abstract}

Assim, a etnografia, que constituía uma perspectiva ${ }^{9}$ utilizada pela antropologia para documentar sociedades não ocidentais (ROCKWELL, 1986), passava no século XX a ser utilizada para a pesquisa de fenômenos ou

\footnotetext{
9 "A palavra etnografia se refere tanto a uma forma de proceder na pesquisa de campo, como ao produto final da pesquisa: classicamente, uma monografia descritiva. Na antropologia, o termo denota muito mais uma ferramenta de coleta de dados e não equivale à observação participante que a sociologia integra como técnica. Tampouco costuma identificar-se apenas como método. Insiste-se muito mais em que ela seja um 'enfoque' ou uma 'perspectiva', algo que se articula com método e teoria, mas que não esgota os problemas nem de uma nem de outro." (ROCKWELL, 1986, p. 32).
} 
instituições próprios das sociedades industrializadas ocidentais (como a escola), o que demandou um esforço de adequação metodológica considerável.

Nessa mesma época, estabelece-se um amplo debate entre os defensores de uma abordagem mais quantitativa e outra mais qualitativa de pesquisa. Para André (1995), as raízes históricas das pesquisas qualitativas estariam nos estudos que se aliaram às ideias de Dilthey (1833-1911) e Weber (1864-1920), e que se basearam em uma perspectiva idealista-subjetivista. A partir dela, questionava-se a utilização de leis gerais ou experimentos para a explicação de fenômenos sociais, e valorizava-se a interpretação do pesquisador (assumindo a sua não neutralidade) e os significados que os indivíduos dão à realidade que os cerca. Constitui-se, assim, a abordagem de pesquisa chamada qualitativa ou "naturalística", por buscar compreender os fenômenos sociais não em experimentos, mas em seu acontecer "natural" (ANDRÉ, 1995).

No entanto, as pesquisas qualitativas não são apenas aquelas que não utilizam dados numéricos quantificáveis. Os dados quantitativos e qualitativos não devem ser opostos, mas vistos em uma relação dialética entre si. Além disso, os dados quantitativos são importantíssimos (apesar de no passado terem ficado muito relacionados a correntes de pensamento que se pretendiam "científicas", objetivas e neutras, como o positivismo), não podendo estar de fora da dimensão qualitativa da pesquisa. A diferença está na maneira com que o pesquisador lida com esses dados, que no nosso caso não é a partir de uma perspectiva cientificista supostamente "neutra", mas a partir de referenciais teóricos e questionamentos do pesquisador à realidade e ao seu material empírico.

Entre os tipos de pesquisa associados à abordagem qualitativa, estaria a etnografia. Segundo a autora, 
O etnógrafo encontra-se, assim, diante de diferentes formas de interpretações da vida, formas de compreensão do senso comum, significados variados atribuídos pelos participantes às suas experiências e vivências e tenta mostrar esses significados múltiplos ao leitor (ANDRÉ, 1995, p. 20).

Para a autora, a pesquisa etnográfica envolveria algumas características: seria participante na medida em que o pesquisador intervém de alguma maneira na realidade estudada; o pesquisador é o sujeito ou "instrumento" que realiza a coleta de informações; preocupa-se com o processo e não apenas com o resultado final das interações; buscaria compreender os significados atribuídos pelos sujeitos às suas práticas sociais; realiza-se em um trabalho de campo.

Para Rockwell (1986), ao utilizar-se dessa metodologia para a pesquisa de certos fenômenos sociais, o pesquisador deve ter uma preocupação em não pensar a etnografia como uma apreensão direta e "ateórica" dos fenômenos sociais, ou um mero registro da maneira que os sujeitos significam a realidade que os cerca. A pesquisa etnográfica, embora muito dedicada a se aprofundar na compreensão do cotidiano das interações sociais, deve assumir-se como uma perspectiva dialética, em que método e teoria se complementam constantemente.

A pesquisa etnográfica deveria iniciar-se com uma discussão teórica, a partir de uma conceitualização - ainda que parcial - de seu objeto:

Pois é claro que, em toda pesquisa etnográfica, encontram-se, implícita ou explicitamente, conceituações do objeto de estudo que definem qual das múltiplas descrições "possíveis" da realidade se deva fazer. Mesmo aquela etnografia, que se supõe ateórica ou "empírica", integra pressupostos teóricos que provêm do "senso comum" antropológico. É impossível, por exemplo, "construir uma teoria de uma cultura particular", como a "veem os sujeitos", sem que se aborde o objeto com uma "teoria particular da cultura". Não é possível prender-se estritamente às categorias "próprias" da cultura estudada, pois o etnógrafo sempre seleciona e ordena o "observável", a partir de sua própria conceituação do objeto estudado. Este fato inevitável não torna menos "objetiva" a etnografia, como 
suporiam alguns. Não invalida por ser "subjetiva" ou "relativista", a descrição etnográfica. A etnografia que melhor expressa e dá conta das relações e dos processos particulares estudados, é consequência do trabalho teórico, e não a 'matéria-prima' para começar a fazê-lo (ROCKWELL, 1986, p. 34-35).

Assim, ao adotar a etnografia como perspectiva, não se está tomando emprestado tão somente uma técnica. Acima de tudo, a pesquisa que se apropria dessa perspectiva assume uma postura metodológica com implicações teóricas.

O pesquisador não é neutro diante desse processo. $O$ seu trabalho de campo por si só é suficiente para influenciar as interações sociais naquele meio, sendo também influenciado por ele, de modo que a pesquisa poderia ser também o que André (1995) denomina participante. Dessa maneira, assume-se que, embora a pesquisa etnográfica tenha que ser feita com rigor metodológico e teórico, no limite é realizada a partir de uma perspectiva assumida, e que de alguma maneira influencia inclusive na análise do objeto de estudo.

Segundo André (ibidem), a partir dos anos 1980 se proliferaram as pesquisas etnográficas em educação. Em que pesem as adaptações que 0 transplante da etnografia para a educação ocasionou (LÜDKE; ANDRÉ, 1986), pode-se dizer que a preocupação dessas pesquisas era estudar as relações entre os sujeitos no espaço escolar, sua dinâmica, representações e jogos de poder. Assim

Esse tipo de pesquisa permite, pois, que se chegue bem perto da escola para tentar entender como operam no seu dia-a-dia os mecanismos de dominação e de resistência, de opressão e de contestação ao mesmo tempo em que são veiculados e reelaborados conhecimentos, atitudes, valores, crenças, modos de ver e de sentir a realidade e o mundo (ANDRÉ, 1995, p. 41). 
Dessa maneira, para a autora, a pesquisa etnográfica no espaço escolar não se restringiria a um mero registro daquilo que é observado no espaço escolar, mas relaciona-se a um esforço teórico-metodológico de compreensão profunda dos processos de interações entre os sujeitos, dos sentidos que atribuem a essas relações e das contradições nas práticas escolares.

Para André (1995), os estudos etnográficos sobre a prática escolar envolvem três aspectos: o primeiro seriam os aspectos institucionais, pois a forma de organização da escola pode possibilitar ou limitar as interações sociais; o segundo seria a dimensão pedagógica, em que ocorreriam as relações de ensino, a utilização de materiais didáticos e a linguagem das aulas; o terceiro aspecto seria o sociopolítico, pois as práticas escolares não podem ser analisadas isoladamente do seu momento histórico, da cultura e das transformações sociais.

Observando a realidade, o pesquisador sempre se encontrará desafiado pelo seu objeto de estudo. O aparente "caos" das interações sociais concretas é contraditório, e pode se opor a sistemas teóricos anteriormente formatados. Por isso a pesquisa etnográfica escolar é importantíssima, pois possibilita a compreensão de determinados tipos de interações e significações construídos pelos sujeitos em seu contexto, desafiando e consequentemente enriquecendo a construção de teorias mais apropriadas às questões escolares.

O objeto de estudo seria, portanto, redescoberto na pesquisa etnográfica escolar. A partir de uma observação e de uma riqueza de detalhes e informações, a pesquisa escolar se centraria no processo de ensino, aproximando as práticas sociais documentadas do leitor da obra. Para tanto, é necessário investigar como são as interações no espaço escolar e como os sujeitos reelaboram e ressignificam a sua relação com o outro, com a escola e com o conteúdo das aulas.

Para isso, é necessário um recorte, feito pelo pesquisador. Para Lüdke e André (1986), isso pode ser feito no estudo de um caso específico. Os estudos de caso enfatizam a 
[...] interpretação em contexto; retratam a realidade de uma forma completa e profunda; usam uma variedade de fontes de informação; permitem generalizações naturalísticas; representam diferentes e conflitantes pontos de vista presentes numa situação social; utilizam uma linguagem mais acessível que outros relatórios de pesquisa (LUDKE; ANDRÉ, 1986, p. 18-19).

A imersão do pesquisador no estudo de caso possibilita pensar a generalidade ou a particularidade dos seus objetos de estudo, o que, de qualquer forma, seria uma grande contribuição para se pensar a educação em geral.

A partir daí, o pesquisador precisa explicitar desde o início seus pressupostos teóricos e confrontá-los o tempo todo com os dados de que dispõe: as relações concretas entre alunos, entre alunos e professores, e a relação dos sujeitos com os instrumentos em sala de aula (sua relação com o livro didático, as tecnologias, com objetos próprios da escola, etc.).

Dessa maneira, faz-se necessário um recorte preciso do objeto de estudo, para que a generalização naturalística própria dessa modalidade de pesquisa (LÜDKE; ANDRÉ, 1986) ofereça elementos para uma melhor compreensão das relações sociais que se quer investigar. O "Estudo de Caso Etnográfico" é utilizado quando o pesquisador, interessado em um caso particular, deseja conhecer profundamente essa realidade e seus processos mais que seus resultados finais, a ponto inclusive de desenvolver novas hipóteses. Para André,

Focalizando uma instância em particular e iluminando suas múltiplas dimensões, assim como seu movimento natural, os estudos de caso podem fornecer informações valiosas para medidas de natureza prática e para decisões políticas (ANDRÉ, 1995, p. 54). 
Para a autora, o estudo de caso etnográfico permite oferecer ao leitor uma espécie de "descoberta" do objeto de estudo, aprofundando a complexidade das relações no espaço escolar, particularmente as relações de ensino e aprendizagem. Os diferentes pontos de vista e formas de agir dos sujeitos que estão em interação são evidenciados, evitando maniqueísmos e permitindo analisar, com uma metodologia sistematizada, as práticas sociais cotidianas que se constituem em sala de aula.

Contudo, essas aulas não podem ser investigadas como se estivessem isoladas de um contexto sócio-histórico mais amplo. Estão localizados em uma sociedade de classes, industrializada e urbanizada; além disso, a escola é alvo de políticas públicas. A pesquisa não pode ignorar a relação entre processos mais particulares e as estruturas mais amplas, de ordem econômica, social e cultural. As informações do contexto externo à sala de aula devem amparar a análise de dados: "Desse modo, não se realizam estudos de casos, mas estudos sobre casos." (ROCKWELL, 1986, p. 47).

O estudo de caso em um contexto escolar deve ser abordado como parte de uma totalidade, contando com a relação entre a escola e o Estado, além das interações com a comunidade e as relações com a própria sociedade em geral. A sala de aula deve também ser analisada em uma perspectiva histórica, situada em uma sociedade de classes, com profundas contradições sociais. Essas contradições ficam ainda mais evidentes ao pesquisarmos as interações entre sujeitos nas aulas de História, em uma turma de EJA.

Contudo, se por um lado a etnografia, ou mais especificamente o estudo de caso etnográfico, nos auxiliaria a investigar de maneira aprofundada as interações entre os sujeitos de uma realidade específica, ainda assim não necessariamente chegaríamos a uma explicação sobre a gênese do funcionamento psicológico humano. Para Góes (2000), embora estudos etnográficos como a microetnografia tenham dado uma imensa contribuição para o estudo dos detalhes das interações socioculturais, eles não explicam suficientemente o papel da cultura nos processos de desenvolvimento dos 
sujeitos. Comentando sobre as pesquisas de Vigotski e sua perspectiva teórica, a autora afirma que

[...] é preciso reconhecer que é de sua obra que se desdobram essas novas possibilidades e que nela pode-se ler o propósito talvez mais característico dessa análise: construir uma microhistória de processos, interpretável somente em uma perspectiva semiótica e numa remissão a condições mais amplas da cultura e da história (GÓES, 2000, p. 22).

Assim, se por um lado a perspectiva do estudo de caso etnográfico pode contribuir imensamente com a abordagem da pesquisa no espaço escolar, com a compreensão das múltiplas relações que ali ocorrem e relacioná-las com contextos mais amplos, a Teoria Histórico-Cultural por outro lado, lança outras questões sobre essas interações no espaço escolar. A partir dela, pode-se pensar como, a partir das minúcias das relações intersubjetivas da turma observada, se possibilita um processo de reelaboração de sentidos e significados sobre certos conceitos da aula de História. Nas análises dos episódios mais adiante, buscaremos um diálogo entre as duas perspectivas.

\subsection{Os discursos em sala de aula}

Os diálogos que ocorrem nas aulas de História da Educação de Jovens e Adultos são muito interessantes pelos seus embates, negociações e tensões. Esses alunos se apropriam dos discursos ideológicos de maneira diferente das crianças em idade escolar. Diferem delas pela sua relação com o trabalho, com a família, com a urbanização, com as práticas culturais das sociedades industrializadas. Sua situação como jovens e adultos em uma sociedade de classes, historicamente constituída, reflete-se nas interações que ocorrem nas aulas de História. Por isso, traremos, um autor da Filosofia da Linguagem, Bakhtin, bem como alguns de seus comentadores, para nos ajudar a refletir sobre as interações da realidade escolar estudada. Também nos utilizaremos 
de alguns autores da Psicologia Discursiva como Derek Edwards, para quem o discurso em sala de aula é constitutivo dos processos psicológicos pelos quais atravessam os sujeitos nas interações escolares.

\subsubsection{O papel da ideologia nas práticas discursivas}

As contribuições de Bakhtin podem ser de grande valia para o estudo das práticas discursivas em sala de aula. Suas pesquisas sobre a disputa de significados e as apropriações da palavra do outro podem ajudar na compreensão dos ricos diálogos ocorridos nas aulas de História.

$\mathrm{Na}$ primeira metade do século $\mathrm{XX}$, ainda circulavam correntes de pensamento que aparentemente menosprezavam o papel da ideologia e seus signos na consciência. Os idealistas acreditavam que a ideologia estaria em algum lugar acima das relações concretas, determinando a consciência. Já para os positivistas, a consciência seria um prolongamento do desenvolvimento do organismo, tanto por causa da evolução das espécies, quanto pela maturação do indivíduo.

Baseados no materialismo histórico dialético de Marx e Engels, Bakhtin e seu círculo aprofundaram questões que seguiam pouco estudadas em relação à linguagem, em meados do século XX. Para eles, nem o marxismo, nem outras perspectivas teóricas, haviam se debruçado de maneira suficiente no tema da ideologia de uma maneira dialética. Para Miotello,

Nesse sentido, partem do que já era aceito pelo marxismo oficial - entender a ideologia como "falsa consciência" - , vista como disfarce e ocultamento da realidade social, escurecimento e não-percepção da existência das contradições e da existência de classes sociais, promovida pelas forças dominantes, e aplicada ao exercício legitimador do poder político e organizador de sua ação de dominar e manter o mundo como ele é. Entretanto, não concordam inteiramente com essa conceitualização. Por isso, destroem e reconstroem parte dessa concepção, colocando ao lado da ideologia oficial a ideologia do cotidiano. A ideologia oficial é entendida como 
relativamente dominante, procurando implantar uma concepção única de produção de mundo. A ideologia do cotidiano é considerada como a que brota e é constituída nos encontros casuais fortuitos, no lugar do nascedouro dos sistemas de referência, na proximidade social com as condições de produção e reprodução da vida (MIOTELLO, 2005, p. 168-169).

Nessa perspectiva, o fato de que os indivíduos estejam organizados cultural e historicamente de uma determinada maneira (e sujeitos ao discurso oficial) faz com os discursos sejam apropriados e recriados justamente no contato e na interação cotidianos entre os indivíduos, nas relações que se dão entre eles, tomando as formas de significação da realidade e reconstruindo-as na dinâmica das interações socais.

A ideologia e seus conteúdos não residiriam, portanto, nem abaixo nem acima das relações concretas entre sujeitos. Seria na interação e sua capacidade em recriar e interpretar o conteúdo ideológico, que a consciência se constituiria semioticamente. Para Bakhtin, "A consciência individual é um fato sócio-ideológico" (BAKHTIN, 2014, p. 35).

As relações sociais antecedem de alguma maneira a consciência, pois são elas que Ihe dão suporte, por meio da ideologia e seu material semiótico, para que ela se constitua e se desenvolva. Bakhtin afirma que

\begin{abstract}
A realidade ideológica é uma superestrutura situada imediatamente acima da base econômica. A consciência individual não é o arquiteto dessa superestrutura ideológica, mas apenas um inquilino do edifício social dos signos ideológicos (BAKHTIN, 2014, p. 36).
\end{abstract}

Aquilo que os indivíduos dizem é, portanto, uma apropriação do conjunto de fenômenos ideológicos presentes e conflitantes na sociedade, refratando em grande parte a correlação de forças entre diferentes visões de mundo. A questão é pensar como é que isso ocorre, ou seja, de que maneira as instituições sociais e fenômenos e práticas ideológicos por elas produzidos, 
bem como a própria tensão dos diversos conflitos sociais (e seu potencial para desestabilizar essas instituições), são constitutivas da consciência individual pelos $_{\text {signos }}{ }^{10}$.

Isso não quer dizer em absoluto que os signos sejam estáveis e que, portanto, a consciência é um vaso a ser preenchido com qualquer conteúdo que lhe depositarem. Nos momentos mais agudos de crises e transformações sociais, as palavras que circulam sofrem grandes transformações e marcam a instabilidade da sua época, abrindo possivelmente novos caminhos inclusive para a criação, disputa e questionamento de significados. Assim,

[...] se poderia caracterizar a ideologia, da perspectiva bakhtiniana, como a expressão, a organização e a regulação das relações histórico-materiais dos homens. Ao mesmo tempo, esse ponto de vista também manifesta sua compreensão diversa da exercida pela ideologia dominante. A superestrutura não existe a não ser em jogo e relação constante com a infraestrutura, defende Bakhtin, e essa relação é estabelecida e intermediada pelos signos, e por sua capacidade de estar presente necessariamente em todas as relações sociais. E em cada uma delas os signos se revestem de sentidos próprios, produzidos a serviço dos interesses daquele grupo (MIOTELLO, 2005, p. 171).

Por isso, para o autor russo não se trata em absoluto de afirmar que a consciência é meramente determinada pela ideologia, como se a superestrutura social fosse absorvida e reproduzida pelas consciências individuais. Nem poderia, já que instituições e práticas ideológicas estão sempre em constante transformação também, e dão o suporte para as

\footnotetext{
10 "Objetos materiais do mundo recebem função no conjunto da vida social, advindos de um grupo organizado no decorrer de suas relações sociais, e passam a significar além de suas próprias particularidades materiais. Uma camiseta na qual se pinta um escudo de um time de futebol é muito mais que uma camiseta. E se for assinada pelo craque de futebol que a usa, incorpora mais valor ainda. Temos aqui o que Bakhtin chama de signo." (MIOTELLO, 2005, p. 170).
} 
interações sociais. Os indivíduos a todo o momento refazem e desfazem as diversas maneiras de significar e dar sentido ao mundo, a partir da dinâmica das relações sociais.

Isso porque os fenômenos psíquicos podem e devem, para o autor, ser explicados à luz das relações sociais. A consciência se apoiaria no organismo, mas sua gênese estaria na produção socioideológica: "o organismo e o mundo se encontram no signo" (BAKHTIN, 2014, p. 50), que por sua vez é constitutivo da consciência.

As mudanças sociais passam pela linguagem e, nessa dinâmica, em um mesmo signo podem encontrar-se diferentes vozes. Em meio às contradições sociais, a consciência dos indivíduos se apropria e recria os discursos ideológicos. Para o autor,

Se o conteúdo do psiquismo individual é tão social quanto a ideologia, por outro lado, as manifestações ideológicas são tão individuais (no sentido ideológico deste termo) quanto psíquicas. Todo produto da ideologia leva consigo o selo da individualidade do seu ou dos seus criadores, mas este próprio selo é tão social quanto todas as outras particularidades e signos distintivos das manifestações ideológicas. Assim, todo signo, inclusive o da individualidade, é social (BAKHTIN, 2014, p. 60).

Assim, o signo ideológico, cuja gênese é sócio-histórica e, portanto, exterior ao organismo, é constitutivo do plano psíquico da consciência dos sujeitos. Por meio da consciência pode-se dizer que as relações sociais "adentram" o organismo: "O psíquico goza de extraterritorialidade em relação ao organismo. É o social infiltrado no organismo do indivíduo." (Ibidem, p. 65). Pelo signo, se compreende e interpreta o mundo.

Nas relações sociais, cada indivíduo, ao falar, está sempre em interação com um interlocutor, que pode estar fisicamente presente, ou não. A interação exige que o locutor "penetre" ou compreenda minimamente o plano psíquico a 
partir do qual fala o seu interlocutor, apoiando-se no contexto discursivo a partir do qual ocorrem os embates ideológicos.

Dessa maneira, para Bakhtin, a dialogicidade possui três dimensões: primeiramente todo dizer é voltado para o que "já foi dito"; segundo, o dizer é orientado à resposta que porventura venha a receber; em terceiro, o dizer é ele próprio, dialogizado. Nessa perspectiva, pode-se dizer que:

Para haver relações dialógicas, é preciso que qualquer material linguístico (ou de qualquer outra materialidade semiótica) tenha entrado na esfera do discurso, tenha sido transformado num enunciado, tenha fixado a posição de um sujeito social. Só assim é possível responder (em sentido amplo e não apenas empírico do termo), isto é, fazer réplicas ao dito, confrontar posições, dar acolhida fervorosa à palavra do outro, confirmá-la ou rejeitá-la, buscar-lhe um sentido profundo, ampliá-la. Em suma, estabelecer com a palavra de outrem relações de sentido de determinada espécie, isto é, relações que geram significação responsivamente a partir do encontro de posições avaliativas (FARACO, 2003, p. 64).

Nesse sentido, para Bakhtin, a recepção ativa do discurso de outrem envolve ao mesmo tempo um discurso interno, que replica psiquicamente o conteúdo recebido, e um movimento de comentário efetivo, que se manifesta socialmente:

É no quadro do discurso interior que se efetua a apreensão do discurso de outrem, sua compreensão e sua apreciação, isto é, a orientação ativa do falante. Esse processo efetua-se em dois planos: de um lado, a apreciação de outrem, é recolocada no contexto de comentário efetivo (que se confunde em parte com - que se chama o fundo perceptivo da palavra); na situação (interna e externa), um elo se estabelece com a expressão facial, etc. Ao mesmo tempo prepara-se a réplica (Gegenrede). Essas duas operações, a réplica interior e o comentário efetivo são, naturalmente, organicamente fundidos na unidade da apreensão ativa e não são isoláveis senão de maneira abstrata (BAKHTIN, 2014, p. 154). 
Portanto, nas interações dialógicas o sujeito se apropria de maneira ativa do discurso do seu interlocutor, recriando-o e, concomitantemente, elaborando uma resposta. $O$ processo de recepção não é passivo, mas ativo, pois a réplica é pensada e falada simultaneamente nas relações sociais. Dessa maneira, se apropriando das palavras do outro, o sujeito se constitui discursivamente, internalizando uma dinâmica de vozes sociais múltiplas (FARACO, 2003).

O sujeito não apreende o discurso do outro apenas de uma maneira. Para Bakhtin, haveria três maneiras de apreensão. Uma forma seria, de maneira linear, citar o discurso lido ou ouvido com contornos rígidos e nítidos para que não se confunda o discurso do próprio sujeito com o discurso de outrem. Essa maneira de apropriação demonstra que, apesar de citar o discurso de outrem, o sujeito não pode ou não quer fazer nenhum comentário sobre, demonstrando certa fraqueza ou precaução no debate.

Outra maneira seria reproduzir o conteúdo do discurso do outro, inclusive com elementos do estilo da fala de outrem, mas com inserções, ironias, elogios, ressaltando seus "pontos fracos" ou "fortes". Assim o sujeito demonstra ter maior intimidade com o conteúdo do discurso de outrem, se sentindo mais à vontade para fazer os seus próprios comentários.

Também há aqueles casos em que o discurso citado é tão forte, que a depender do contexto narrativo, ele mesmo torna-se mais forte que o próprio discurso do sujeito. Nessa situação, o discurso de outrem é tão importante, ou a intenção daquele que o cita é fazer parecer assim, que seu conteúdo se sobressai sobre o daqueles que estão trazendo o debate.

De qualquer maneira, em todos esses casos, conclui-se que

A língua não existe por si mesma, mas somente em conjunção com a estrutura individual de uma enunciação concreta. É apenas através da enunciação que a língua toma contato com a comunicação, imbui-se do seu poder vital e torna-se uma realidade (BAKHTIN, 2014 p. 160). 
Assim, nas relações concretas entre sujeitos, ocorrem as enunciações e seus processos interativos, percebidas ou presumidas nas palavras, e no contexto sócio-histórico em que se dão, projetando-se e antecedendo o que vem adiante no diálogo (BRAIT, 2005).

O diálogo, por sua vez, não significa consenso; é a palavra contra a palavra de alguém, muitas vezes em momentos de tensão e enfrentamento (MARCHEZAN, 2006). Essa interação força os sujeitos a se apropriarem de alguma maneira do discurso de outrem, para dar-Ihe o apoio, o contraponto ou alguma observação. Segundo Vóvio,

O discurso ganha sentido a partir do contexto em que é enunciado e depende em grande medida da atividade dos sujeitos em ressignificá-lo de acordo com as circunstâncias nas quais a comunicação se processa. Na comunicação humana estão envolvidos elementos que se inter-relacionam: o contexto em que ela se dá, a relação entre os interlocutores e o horizonte sócio-histórico que a emoldura. A forma que 0 discurso irá tomar, a escolha de palavras e expressões e sua entonação dependerá do objeto do discurso e daquele a quem se destina o enunciado (VÓVIO, 1999, p. 15).

Dessa forma, o discurso nunca se dá de maneira "pura" na comunicação, mas sempre mediada pelo contexto sócio-histórico da interação entre os sujeitos. Essa relação, dialógica, nos leva a pensar que a comunicação se dá como resposta, mas também como antecipação, ao diálogo social no qual está inserida. Assim, os sujeitos se constituem nos embates ideológicos das suas relações sociais, se apropriando delas à sua própria maneira:

Pode-se afirmar que para analisar a linguagem há elementos que devem ser tomados de forma indissociável: a situação discursiva, os sujeitos envolvidos na situação (interlocutores), o 
conteúdo, o gênero e, de modo mais geral, a situação sóciohistórica em que foi produzida (VÓVIO, 1999, p. 16).

O discurso, como prática sócio-ideológica, passa também pela utilização, por parte dos sujeitos da comunicação, de diferentes gêneros. Eles dependem não apenas do domínio da linguagem, mas, sobretudo, de práticas sociais específicas de determinados círculos sociais. Os diversos gêneros surgem a partir da complexidade das relações sociais, em determinado contexto sócio-histórico (BAKHTIN, 2014). Os sujeitos dominam certos gêneros quando têm familiaridade com certas práticas sociais; podem-se refletir na dinâmica das interações dentro de determinados contextos. A atividade dos sujeitos e a linguagem utilizada estão intimamente relacionadas: a partir dos gêneros do discurso, os sujeitos não agem ou falam de maneira descontextualizada. Para Faraco,

\begin{abstract}
Em outros termos, o que é dito (o todo do enunciado) está sempre relacionado ao tipo de atividade em que os participantes estão envolvidos. Do mesmo modo, se queremos estudar qualquer das inúmeras atividades humanas, temos de nos ocupar dos tipos de dizer (dos gêneros do discurso) que emergem, se estabilizam e evoluem no interior daquela atividade, porque eles constituem parte intrínseca da mesma (FARACO, 2003, p. 111-112).
\end{abstract}

Nessa perspectiva, falar e agir estão mutuamente relacionados. Cada atividade pressupõe um tipo de fala, de interação, de diálogo. O dizer se dá por meio de gêneros, em determinadas práticas societárias. Em cada atividade humana específica, há enunciados que são relativamente estáveis, sem os quais a comunicação seria impossível. Por outro lado, assim como as próprias atividades tem a sua historicidade, os enunciados também estão abertos a certas mudanças. Os gêneros do discurso não são nem previsíveis, nem casuais, mas com relativa estabilidade, são organizadores de atividades e constituem psiquicamente a consciência dos sujeitos. Dessa maneira 
Ao gerarem expectativas de como serão as ações, eles nos orientam diante do novo no interior dessas mesmas ações: auxiliam-nos a tomar o novo familiar pelo reconhecimento de similaridades e, ao mesmo tempo, por não terem fronteiras rígidas e precisas, permitem que adaptemos sua forma às novas circunstâncias (FARACO, 2003, p. 115).

Nas práticas sociais haveria, portanto, determinadas esferas sociais, onde um certo uso da linguagem é reconhecido pelos sujeitos, mas a partir do qual também surgem inovações advindas das interações sociais, das transformações históricas e culturais. Em cada contexto, são esperados certos tipos de enunciação, o que não impede a eventual contaminação de discursos que normalmente seriam identificados a outros gêneros (MACHADO, 2005).

Para se analisar a linguagem utilizada nas interações entre sujeitos no espaço escolar, há que se levar em conta a situação sócio-histórica da escolarização nos dias de hoje, bem como os discursos ideológicos na dinâmica de sala de aula, mais especificamente na aula de História. A escola como instituição constituída historicamente, é o contexto em que diversas práticas discursivas são colocadas á prova, particularmente por alunos e professores da Educação de Jovens e Adultos.

\subsubsection{O discurso nas práticas escolares}

O estudo das práticas discursivas em contextos escolares pode trazer muitas contribuições para a investigação sobre a constituição do pensamento e da linguagem em sala de aula. A seguir, traremos alguns autores da Psicologia do Discurso, como Derek Edwards, que se dedicaram a essa questão, e outros da Teoria Histórico-Cultural, para refletirmos como, no contexto escolar, as 
práticas sócio-discursivas possuem algumas particularidades na constituição de subjetividades ${ }^{11}$.

Para Edwards (1998), desde os anos 1980 se aprofundaram estudos com diversas linhas metodológicas que passaram a se dedicar ao estudo da produção do conhecimento do ponto de vista das práticas discursivas. A teoria de Vigotski tem oferecido muita inspiração para a análise do discurso em sala de aula, embora efetivamente não tenha sido elaborada com esse intuito. Mesmo assim, discussões como a da Zona de Desenvolvimento Proximal, por exemplo, podem ajudar a fornecer elementos para a elaboração de uma teoria sobre o ensino e a aprendizagem na sala de aula, a partir do seu olhar sobre as interações sociais e mediações ao longo do processo de desenvolvimento (EDWARDS, 1998, p. 24).

Segundo Mercer (1998), o discurso em sala de aula nunca é individual, mas parte de um processo de construção coletivo, produzido por diversos sujeitos ou vozes presentes nos diálogos. Essa construção não ocorre com a participação de todos os sujeitos envolvidos de maneira ininterrupta, mas sem dúvida não é um mero amontoado de mensagens. Ocorre nas práticas discursivas nas quais participam os sujeitos em sala de aula de maneira ativa.

Embora os indivíduos não estejam amarrados na estrutura social a ponto de afirmarmos que os discursos produzidos são meros reflexos do ambiente social, também não é possível, nessa perspectiva, desconsiderarmos a gênese sócio-histórica dessas práticas. Assim, os embates ideológicos, por mais ricos e produtivos que sejam, somente se realizam a partir de determinados contextos sociais. Para Valsiner,

\footnotetext{
11 Estudos muito interessantes sobre a Psicologia Discursiva tem sido realizados na Loughborough University, onde além dos estudos de Derek Edwards, que comentaremos mais adiante, destacam-se as pesquisas de Michael Billigs sobre o nacionalismo, a retórica e a ideologia (BILLIGS, 1976).
} 


\begin{abstract}
A grande sensibilidade no contexto dos fenômenos psicológicos imediatamente disponíveis e a irregularidade do perfil das funções em desenvolvimento em qualquer momento indicam que por detrás da aparente autonomia do momento presente de uma pessoa há uma história de vida inteira de interdependência social (VALSINER, 1998, p. 31).
\end{abstract}

Assim, o contexto em que determinado discurso é colocado em prática pelos sujeitos circunscreve a negociação de sentidos ocorrida nas disputas e embates nas relações sociais. O sujeito se esforça por reconstituir individualmente os discursos que lhes são oferecidos, e busca prever para onde o debate irá para responder à altura. É esse jogo, que opera no tempo de maneira irreversível, que coloca limites para a ação do discurso.

Para o autor, mesmo assim, o discurso é bastante fluido, acompanhando, na prática, o ritmo psicológico da mediação semiótica, particularmente na escola. O número de sujeitos envolvidos, os papeis que assumem, as atividades propostas, tudo isso torna o estudo do discurso em sala de aula bastante complexo. Tudo aquilo que é dito e realizado, bem como a maneira como é feito, é o que dá o contexto da prática discursiva em sala.

Evidente que a escola está situada em uma determinada sociedade, sendo sua tarefa ajudar a criança a reconstruir internamente as regras sociais para as quais a educação está orientada. Isso não quer dizer de maneira alguma que em diversos momentos, nas práticas discursivas de professores, alunos e outros, não se encontrem elementos de contestação ou mesmo resistência em relação ao status quo.

Segundo o autor, as diversas atividades propostas pelo professor em geral estão subordinadas ao contexto educacional em que se aplicam. No entanto, a orientação de uma intervenção pedagógica intencional não encerra o conjunto de eventos que ocorrem nesse espaço. A pesquisa sobre o discurso em sala se aula, embora situada em um espaço onde culturalmente a atividade pedagógica restrinja as práticas discursivas, deve também se dedicar às falas, particularmente proveniente de alunos, que aparentemente nada tem a ver com 
o planejamento do professor. Somente assim se poderá compreender o desenvolvimento dos alunos a partir das práticas discursivas produzidas ali. Entre as principais atividades rotineiras das crianças, estão incluídas as que estão relacionadas diretamente com 0 ensino e aprendizagem dos conhecimentos escolares, aquelas que são destinadas a construir uma pertença coletiva ao grupo, e finalmente as atividades que aparentemente não tem a ver com o ensino, como as realizadas nos intervalos entre as aulas. Frequentemente, essas atividades se entrecruzam, subvertendo a ordem social posta:

Entretanto, no discurso real em sala de aula, os alunos podem fazer esforços episódicos para renegociar a estrutura semiótica da aula: uma cesta de papeis pode transformar-se, funcionalmente, em uma cesta de basquete, mas dentro das restrições gerais das atividades de aula [...] (VALSINER, 1998, p. 37).

Nessa perspectiva, o discurso em sala de aula também é profundamente restringido pelos papeis sociais que se impõem aos sujeitos na escola. Dos adultos, se espera que cuidem, mas também que ensinem e instruam crianças que não são do seu convívio familiar. Das crianças, se espera que "recebam" o conteúdo escolar e sejam capazes de reproduzi-lo após algumas aulas com determinado planejamento curricular. Quando tanto professores quanto alunos, de alguma maneira, subvertem essas posições socialmente construídas, abrem-se frequentemente situações de conflito que, por sua vez, constituem embates e disputas nas práticas discursivas. Pode-se afirmar, portanto, que os papeis sociais em sala de aula já estão previamente constituídos historicamente, restringindo as falas dos sujeitos nesse contexto. Ao mesmo tempo, porém, na medida em que os eventos das aulas se desenvolvem na sala, diversas renegociações são realizadas, estabelecendo os cenários dessas práticas sociais. 
O desenvolvimento dos sujeitos não é previsível ou controlável, embora seja orientado pela cultura. Para o autor, quanto mais as atividades pedagógicas tiverem finalidades específicas, menor é o espaço de renegociação de sentidos e papeis em sala de aula, embora evidentemente isso não quer dizer que essas disputas deixem de ocorrer.

A maneira como se "co-constroem" os discursos em sala de aula interessa em pesquisas como essa na medida em que constituem 0 desenvolvimento dos sujeitos nas relações em sala de aula. Em determinados contextos sociais como o escolar, o discurso pode ser analisado como fonte para investigar o processo de construção de conhecimentos e formas de pensar dos sujeitos em questão. Para Edwards,

\footnotetext{
É através da natureza do discurso como construtor da mente e do mundo que os participantes (professores e alunos) vivenciam os processos epistêmicos públicos da educação. E é a mesma natureza sócio-epistêmica do discurso, disponível publicamente, que possibilita aos pesquisadores fazer uma análise de como os participantes fazem isso, sem a necessidade de criar métodos especializados como os testes e experimentos psicológicos (EDWARDS, 1998, p. 47).
}

A educação, nessa perspectiva, é vista como uma prática cultural, em que a interação entre sujeitos no espaço público é particularmente significativa, tanto para o processo de escolarização dos sujeitos, quanto para a pesquisa em educação. Essa interação é interessante para as pesquisas que desejam se aprofundar nos processos psicológicos dos sujeitos. Evidente que as relações no espaço escolar estão situadas em um contexto histórico-social mais amplo, cujos elementos podem inclusive estar sendo reproduzidos de alguma maneira em sala de aula (relações de classe, raça, gênero, etc.). Cabe aos pesquisadores observar empiricamente a riqueza dessas relações e daí tirar-Ihes uma interpretação, em consonância com os debates teóricos sobre o tema. 
Nessa perspectiva, a relação entre as práticas sociodiscursivas e o contexto em que ocorrem poderia ser colocado em termos da sua institucionalização. O discurso escolar não é institucionalizado apenas por ocorrer no espaço escolar, e sim porque os sujeitos que dele participam assumem papeis sociais próprios da instituição escolar (professor, aluno, etc.) e a partir desses papeis interagem socialmente.

Para Edwards, é preciso pensar uma "Psicologia do Discurso" que analise tanto 0 discurso dos participantes com relação àquilo que eles entendem ser a ciência e o conhecimento e/ou a realidade que os cerca, quanto os recursos explicativos dos sujeitos com relação ao conteúdo que desejam evidenciar. Assim,

Em todo tipo de discurso, não somente no da educação, são justamente esses os tipos de problemas com os quais os participantes precisam lidar: como é o mundo, o que ocorreu em determinado acontecimento, o que sabem sobre ele e como pode ser explicado (EDWARDS, 1998, p. 53).

As opiniões dos participantes sobre o mundo, segundo o autor, não são produções individuais ou meras reproduções dos livros escolares, mas são na verdade práticas sociais discursivas cuja gênese é social. Nesse sentido, é o fato de que os participantes produzem o seu discurso publicamente que garante que sua fala seja reconhecida e possa ser minimamente interpretada. A escola constitui, dessa maneira, um excelente espaço de análise discursiva, pela natureza pública das práticas pedagógicas.

Outro elemento importante em uma psicologia discursiva para Edwards, e que se relaciona às pesquisas de Bakhtin (BAKHTIN, 2014), seria o fato de que toda fala se encontra em meio a um diálogo que já está posto. Dessa maneira, toda fala é uma resposta a uma fala anterior, e também uma antecipação das possíveis respostas que irá receber. Na escola, esse elemento 
sequencial das falas aparece tanto nas relações entre os participantes quanto na construção do conhecimento sistematizado das disciplinas.

Justamente porque toda fala se encontra em meio a uma sequência, há que se analisar a retórica, ou seja, as táticas utilizadas para lidar com problemas básicos de interação. ${ }^{12}$ Em geral, os sujeitos se esforçam em sua fala para destacar pontos em comum com os demais participantes, evidenciar contradições dos oponentes, justificar suas opiniões, dialogar com possíveis interpretações da sua fala.

Segundo Edwards (1998), na escola, é particularmente interessante o que cada participante compreende acerca do mundo ao seu redor, que categoria utiliza para pensá-las, bem como o mundo psicológico a partir do qual cada sujeito se refere ao mundo e interage com os demais. Além disso, é comum que nas práticas sociais escolares haja também uma espécie de responsabilização dos sujeitos pelas suas opiniões. É como se a fala dos participantes lhes marcasse um posicionamento em relação aos demais que é levado em conta por todos. Por isso, apesar de serem importantes as pesquisas que se baseiam em experimentos psicológicos externos à escola, é na análise das interações no espaço escolar que percebemos as implicações dos papeis sociais levados pelos sujeitos. São muito significativas as consequências para os demais daquilo que é dito, e as categorias de conhecimentos sobre o mundo que se constituem na instituição escolar. Dessa maneira, esse tipo de análise também extrapola a análise etnográfica dos dados de um determinado contexto social, uma vez que se dedicam a analisar a participação e a interação social discursiva dos sujeitos. Para Edwards,

\footnotetext{
${ }^{12}$ Embora não nos deteremos a esse tema, a retórica também é constitutiva dos processos psicológicos: "Para Billigs (1991), a crítica que deve ser feita à Psicologia Social não é que seja retórica, mas que não é suficientemente retórica, no sentido de que tende a passar por cima dos aspectos essencialmente retóricos da comunicação. A ideia básica defendida por esse psicólogo social é que o pensamento está modelado pelos processos de argumentação ou, o que é o mesmo, que o que fazemos quando pensamos é produzir argumentos que não seriam possíveis se não existissem formas de argumentação retórica que são interpessoais e públicas". (ÁLVARO; GARRIDO, Psicologia Social: perspectivas psicológicas e sociológicas, 2003).
} 


\begin{abstract}
A psicologia discursiva não questiona filosófica ou realisticamente as relações entre mente e realidade; pelo contrário, toma as práticas públicas do discurso como seu objeto e analisa como essas distinções mente-mundo e as suas relações fazem parte das atividades tais como aquelas em sala de aula. Ou seja, ela as analisa como questões que afetam os participantes (EDWARDS, 1998, p.70).
\end{abstract}

Dessa maneira, a análise do discurso não pode ficar limitada a realizar comentários sobre as falas dos sujeitos, mas aborda, a partir do discurso dos participantes, elementos psicológicos e sua relação com a realidade, tendo sempre em mente a totalidade do contexto social. Para fins de escrita da pesquisa, seria interessante focar as análises em tópicos; como professor e alunos resolvem (ou não) suas diferenças nos diálogos, o que os alunos entendem sobre um tema trabalhado na escola, ou como faremos mais adiante, quais as elaborações conceituais que os participantes trazem ou produzem no espaço escolar.

Para Fontana (2005), as relações pedagógicas ocorrem em certas condições onde se dão as interações, circunscrevendo as possibilidades de práticas discursivas. Ao mesmo tempo, nas interações e no uso da palavra na fala dos sujeitos nas relações pedagógicas, haveria o confronto polêmico de diferentes vozes ideológicas. Para a autora, "Há, portanto, uma 'interação dialética indissolúvel' entre a atividade psíquica (do sujeito) e os signos exteriores (do ideológico)." (FONTANA, 2005, p. 27).

Segundo Smolka (2006), Vigotski teria chamado a atenção para a dimensão semiótica da existência humana. Não haveria experiência histórica e social sem significação da mesma por parte dos sujeitos, nas interações por eles constituídas. Para a autora,

Vygotsky enfatiza a importância de se compreender a emergência do signo na história, isto é, de se compreender uma história do signo e propõe a significação como princípio, 
como chave para a compreensão de como a cultura, enquanto produção humana, vai se inscrevendo nos organismos, deixando marcas nos corpos. O signo produz-se nas relações entre os homens e, como produção humana, afeta os participantes nessas relações (SMOLKA, 2006, p. 106).

Assim, na experiência e nas interações sociais com o outro, os sujeitos elaboram sentidos sobre a realidade. Para Smolka (2006), em sala de aula as expectativas entre sujeitos (professores e alunos) nem sempre coincidem; as respostas dadas nas conversações nem sempre correspondem àquilo que os planejamentos pedagógicos demandavam. Mas é no interior dessas diferenças, na alteridade entre os sujeitos, que se abrem as possibilidades de significação.

\subsubsection{Do socialmente construído para o psicologicamente constituído}

Para Edwards e Mercer (1988), o conhecimento compartilhado é próprio dos seres humanos. Mesmo os primatas superiores, apesar de serem capazes de comunicar-se em larga escala, não são capazes de simbolizar seus pensamentos para outrem fora do contexto onde tais ações se aplicam. Compartilhar conhecimento significa que duas ou mais pessoas passam a saber o que anteriormente só era sabido por uma, ou que chegaram a um novo nível de compreensão diferente do anterior não apenas porque o conhecimento foi compartilhado, mas porque ao submetê-lo à opinião do outro, ele foi modificado pela interação e diálogo entre os participantes.

Segundo os autores, para se estudarem os discursos, é preciso compreender que os diálogos não foram feitos para responder às perguntas do pesquisador. Para analisar o discurso, é necessário recortar um trecho da conversação e partilhá-la com o leitor, evidenciando os elementos que levaram a determinadas conclusões ou suposições. Outra questão é que o investigador não deve se prender a questões formais como o esquema "iniciação (professor) - resposta (aluno) - feedback (professor)" para analisar o discurso em sala, mas se atentar ao conteúdo de construção coletiva do conhecimento 
entre os participantes para compreender a dinâmica das interações nesse espaço.

Nesse sentido, são relevantes também as contribuições de Smolka (2000) sobre a apropriação de signos e práticas culturais da escola, que ocorre de maneira singular para cada indivíduo. Cada sujeito toma como seu (torna próprio) os instrumentos semióticos à sua própria maneira, transformando a si e aos outros, em um jogo de significações. Dessa maneira,

\begin{abstract}
De fato, usualmente, a internalização e a apropriação de meios culturais de mediação são consideradas, referidas e avaliadas como aprendizagem e domínio de maneiras de fazer as coisas e parecerem acontecer somente quando é possível "observar", "ver", de algum modo, a adequabilidade, a pertinência das ações. Aqui, tornar adequado é geralmente tomado como um indicador de tornar próprio.
\end{abstract}

No entanto, tornar próprio não significa exatamente, e nem sempre coincide com tornar adequado às expectativas sociais. Existem modos de tornar próprio, de tornar seu, que não são adequados ou pertinentes para o outro (SMOLKA, 2000, p. 32).

Dessa maneira, para a autora, os alunos desenvolvem certos modos de participação que podem ou não coincidir com as expectativas dos currículos escolares, dos projetos pedagógicos, dos planejamentos do professor. Podem, inclusive, se apropriar de determinadas práticas, métodos ou conceitos de maneira considerada inadequada pela escola, o que não significa que não estejam aprendendo. Para Smolka, a não coincidência de sentidos deve estar no centro da análise discursiva.

Possivelmente, as relações de ensino estejam relacionadas a essa não coincidência de sentidos. Para Edwards e Mercer (1988), são relativamente comuns os seguintes pressupostos das atividades pedagógicas para os professores: criar condições para que os alunos "descubram coisas por si mesmos"; planejar ações "práticas" com os alunos; levantar conhecimentos gerais que os alunos possam ter sobre determinados temas, ao invés de 
comunicar diretamente aos alunos as informações principais; tentar chegar nelas por meio de um jogo de perguntas e respostas; não informar aos alunos toda a sequência didática a ser construída ao longo das aulas; não definir de antemão quais os objetivos que em cada etapa se espera com relação ao desenvolvimento dos alunos. Dessa maneira, percebe-se que os professores de alguma maneira contam com um conjunto de teorias que se relacionam com a sua prática pedagógica, que, por sua vez, se assemelham com o que usualmente se consideram teorias "progressistas" da educação. Enquanto a educação "tradicional" primava pelo ensino, a educação "progressista" privilegiaria a aprendizagem. Segundo os autores, na teoria piagetiana, o professor teria um importante papel para orientar as atividades escolares, mas é a relação do aluno com os objetos do conhecimento o real "motor" do desenvolvimento.

Para os autores, muito do conjunto de conhecimentos que embasa a prática pedagógica dos professores tem a ver com a popularização das teorias piagetianas (ou uma interpretação delas) nas políticas públicas de diversos governos a partir da década de 1970. Dessa maneira, o aluno passou a ser visto não como um receptáculo previamente vazio a ser preenchido pelo conhecimento (educação tradicional), mas um "organismo solitário", que aprende a partir de sua relação dialética com os "objetos do conhecimento" em direção a níveis cognitivos mais complexos.

Mesmo assim, embora contraditoriamente grande parte dos professores pareça reivindicar (sinceramente, inclusive) teorias chamadas "progressistas" na educação, é muito comum que na prática subsistam muitos elementos da educação "tradicional", particularmente na pouca abertura que é dada para a fala dos alunos. É possível que condições de trabalho inadequadas expliquem porque os professores não necessariamente consigam trabalhar da maneira como eles próprios defendem que seja a educação básica. Para Edwards e Mercer, pode-se falar de uma "ideologia" da educação: 
Em primeiro lugar, a prática da educação tem lugar em um contexto cultural e ideológico tal que é provável que os critérios que definem bons ensino e aprendizagem alcançados estejam incluídos nas lições de maneira implícita, ainda que, em certa medida, professores e alunos possam articulá-los se couber. Em segundo lugar há, dentro da ideologia do ensino, uma tensão entre as noções de educação tanto com relação à "extração" do potencial e aptidão dos alunos, e, por outro lado, a necessidade de introduzir os alunos em uma cultura já existente do conhecimento, pensamento e prática "educados" (EDWARDS; MERCER, 1988, p. 56, tradução nossa).

Embora em qualquer tipo de conversação haja regras sociais, em geral, nas conversas em sala de aula, encontram-se regras específicas das interações sociais. Essas características são interessantes não apenas pela forma como operam, mas porque nelas são construídos os conhecimentos que orientam as atividades pedagógicas. Em geral, podem-se destacar três compreensões a respeito das conversações em sala: o professor é quem realiza as perguntas; o professor conhece (boa parte) as respostas e a repetição dessas perguntas pressupõe a possibilidade de aparecerem respostas equivocadas (EDWARDS; MERCER, 1988). Assim, os professores parecem fazer as perguntas não para levantar informações novas e/ou relevantes, mas para testar frequentemente se os alunos estão atentos ao "conteúdo" das aulas, se há um conhecimento compartilhado.

Muitas dessas regras na conversação não são conscientes. É possível que muitos participantes das aulas não sejam capazes de identificá-las como estamos fazendo aqui. Mas isso não quer dizer que professores e alunos não sejam capazes de operar dentro dessas regras, de maneira muito apropriada, diga-se de passagem. Outras vezes, certos alunos (e porque não, alguns professores?), por não se enquadrarem nessas regras implícitas, podem ser estigmatizados como menos capazes. Ou os alunos que não compreendem corretamente conteúdos ou regras são rotulados como "desatentos", ou defasados em seu desenvolvimento cognitivo, ou os professores são acusados de não ter ensinado bem os alunos. Para os autores, pouco se discute que talvez a linguagem em sala de aula seja um meio problemático, que abre possibilidade para a ocorrência de inúmeros mal-entendidos. 
Para Orlandi (1996), o professor costuma ocultar a si mesmo como mediador, e apresentar-se como o detentor do conhecimento científico como se não houvesse aí um processo, como se a sua fala, no ensino, equivalesse ao produto da pesquisa científica. Essa posição de autoridade é posta pela maneira como o ensino está historicamente colocado. Nessa perspectiva, para o aluno, cuja posição também é historicamente posta, ouvir a fala do professor equivale a apreender o conhecimento científico. $O$ material didático frequentemente passa de meio para objeto, sendo não apenas um instrumento, mas ele próprio também o suporte do conhecimento. Esses elementos constituiriam o Discurso Pedagógico (DP), que para a autora, seria essencialmente autoritário. $O$ professor ensina o que está no material, e o aluno deve apreender esse conteúdo. Para a autora,

\begin{abstract}
A escola atua através da convenção: o costume que, dentro de um grupo, se considera como válido e está garantido pela reprovação da conduta discordante. Atua através dos regulamentos, do sentimento do dever ser que preside ao DP e este veicula. Se define como ordem legítima porque se orienta por máximas e essas máximas aparecem como válidas para a ação, isto é, como modelos de conduta, logo, como obrigatórias. Aparece, pois, como algo que deve ser. $\mathrm{Na}$ medida em que a convenção, pela qual a escola atua, aparece como modelo, como obrigatória, tem o prestígio da legitimidade (ORLANDI, 1996, p. 23).
\end{abstract}

Nesse sentido, a escola seria a instituição constituída historicamente por meio do qual se veicula o chamado Discurso Pedagógico. Através dela, legitimam-se determinadas práticas relacionadas ao ensino, à autoridade do professor, reproduzem-se desigualdades, estabelece-se que certos saberes são mais válidos que outros.

No entanto, para Edwards e Mercer (1988), uma vez que o sistema educacional está constituído historicamente dessa maneira, acaba sendo necessário que os alunos tenham contato com a escolarização como historicamente está posta. Isso não quer dizer que não possamos ser críticos quanto à eficácia dessas práticas no ensino dos alunos, ou que não possamos 
comentar a distância que há entre os rituais escolares e as formas de pensar que são construídas no cotidiano.

Segundo os autores, em geral a chamada "ideologia da educação" está baseada em três práticas educacionais. Em primeiro lugar, parte-se do pressuposto de que as regras que balizam as conversações em sala de aula são implícitas, não sendo necessário contextualizá-las ou relembrá-las aos alunos, causando evidente confusão. Em segundo lugar, em nome de preservar a sequência dos planejamentos de aulas, há um certo costume em manter a "ignorância" dos alunos com relação a certos temas, mantendo o professor como o detentor da "autoridade" e do "conhecimento" velado, que ainda não foi apresentado aos alunos. Em terceiro lugar, as ideologias "progressistas" da educação cumprem fortíssimo papel, dando o tom das conversações em sala de aula, se orientando por uma suposta construção coletiva do conhecimento.

Para Edwards e Mercer (1988), quando os alunos conseguem compreender o processo, eles se apropriam dos princípios que são utilizados em sala de aula. Se isso ocorre, pode-se dizer que o conhecimento foi compartilhado de maneira minimamente adequada. Em muitos casos, porém, os alunos adquirem um conhecimento do ritual, ou seja, aprendem que se reproduzirem determinadas posturas, ou derem determinadas respostas, obterão um resultado satisfatório do ponto de vista das práticas escolares, sem, no entanto, compreenderem a fundo as metodologias ou os conhecimentos que a escola se propôs a ensinar. Embora na prática seja difícil de identificar claramente as distinções entre princípios (entendimento de conceitos e sua relação com as atividades propostas) e rituais (procedimentos cuja razão não se torna evidente aos alunos) da maneira como os autores colocaram, na análise dos discursos em sala de aula, isso pode ser identificado.

Os alunos seriam "treinados" a perseguir as respostas convencionalmente "corretas", e se esforçam para isso. Não Ihes parece claro, nesse modelo, as explicações e os "porquês" daquilo que fazem, e quando questionam algo nesse sentido, frequentemente tem sua voz desautorizada. 
Parte-se do pressuposto de que se deve deixá-los à vontade para espontaneamente chegar às deduções corretas, mas estas não são aleatórias e já existem previamente, no planejamento do professor, no material didático, etc.

Embora na prática o ensino possibilite o que para a Teoria HistóricoCultural seria um desenvolvimento de determinadas funções superiores como 0 pensamento conceitual, sem dúvida o processo se torna problemático devido às limitações citadas acima. Aparentemente, a contradição que se coloca segundo esses parâmetros na construção do conhecimento coletivo seria como fazer com que os alunos aprendam o conteúdo de um currículo que foi previamente imposto a eles.

Para Nogueira (2010), as regras e normas escolares nem sempre são explicitadas, mas estão constantemente presentes nas interações em sala de aula. Muitas dessas práticas podem ser encontradas nas mais variadas realidades escolares, a despeito das particularidades locais. Mesmo assim, se manifestam de maneira própria em cada contexto, de acordo com as relações concretas ali existentes. A escola atuaria assim, orientada por uma regulação dos sentidos, elaborações e significações dos sujeitos. Em suas pesquisas, a autora concluiu que

As relações e as práticas sociais são marcadas por maneiras
específicas - histórica e culturalmente constituídas - de agir e
comportar-se. Embora existam expectativas com relação ao
modo dos indivíduos se conduzirem em determinadas
situações e contextos, nem sempre as normas, que delimitam
aquilo que é ou não adequado, chegam a ser explicitadas de
forma clara. Em algumas salas de aula, por exemplo, as regras
não chegam a ser ditas, mas estão sempre presentes, marcam
as interações, como uma teia que envolve a todos
constantemente (NOGUEIRA, 2010, p. 58).

Para a autora, não apenas haveria normas um tanto ocultas, mas presentes, nas práticas escolares, mas elas inclusive teriam papel significativo 
nas interações em sala de aula. No entanto, a imposição dessas regras não garante o seu pleno cumprimento, pois nas interações ainda há espaços para a ressignificação e a reelaboração de sentidos e formas de ser.

$\mathrm{Na}$ educação em geral, e particularmente na Educação de Jovens e Adultos, possivelmente encontramos um discurso ideológico que, por um lado, leva os professores a focarem a intervenção pedagógica na aprendizagem do aluno, e por outro, propõe conteúdos previamente estabelecidos, os quais se espera que os alunos de maneira autônoma aprendam a partir do seu "nível" de desenvolvimento. Se levarmos em conta que cada sujeito de apropria de maneira singular dos conteúdos escolares, e que a escolarização não tem o controle sobre a multiplicidade de sentidos que os sujeitos podem atribuir a esses conhecimentos, a análise das práticas discursivas se torna instigante para aprofundarmos o olhar sobre a constituição de subjetividades nas relações de ensino, particularmente nas aulas de História observadas.

\subsection{Ensino de História e consciência histórica}

A História tem sido uma disciplina constante nos currículos escolares. $O$ seu lugar nos currículos escolares foi constituído historicamente, e é relativamente aceito pelos sujeitos que frequentam as escolas até hoje, em que pesem questionamentos sobre a sua importância nos currículos nacionais. A escola tem sido vista como um lugar privilegiado para se ensinar e aprender História.

Por outro lado, nas listas dos livros mais vendidos nas principais livrarias do país, por vezes encontramos trabalhos relacionados à História (inclusive de seriedade duvidosa). Na televisão, encontram-se muitos programas, séries, videoclipes, novelas, filmes, etc., sobre temas históricos. Muitos jogos de vídeo-game, bastante popularizados entre crianças e jovens, têm trazido narrativas históricas. As discussões políticas, por vezes presentes não apenas na política institucional, mas também em movimentos sociais e culturais, 
trazem sempre alguma noção de História, sobretudo para justificar determinados posicionamentos. Junto a elas, percebe-se também o peso das igrejas, que veiculam determinada versão da história ligada à sua religião. Todas essas instituições da cultura contemporânea divulgam versões da História de maneira informal, porém com certa eficácia em determinados setores da população.

Dessa forma, a História está presente, seja em um contexto de escolarização, onde será ensinada de maneira sistematizada na escola, seja de maneira informal, como parte da cultura contemporânea, que parece reservar um lugar de destaque para ela. De uma forma ou de outra, constitui-se uma consciência histórica nos sujeitos jovens e adultos que interagem com essas instituições e meios de comunição ou entretenimento. A consciência histórica seria essa noção do passado, histórica e socialmente constituída nos sujeitos. No caso dos alunos da Educação de Jovens e Adultos, cuja experiência é marcante na sua formação, que consciências históricas são trazidas para as aulas? Como esses alunos interagem com a História ensinada na escola? Para ajudar a responder a essas questões, vamos nos aprofundar um pouco no que seria a consciência histórica de que tratam alguns autores.

\subsubsection{Experiência e expectativa na História}

Para Koselleck (2006), no século XVIII, a História era pensada como um campo do conhecimento capaz de ligar passado e presente a partir da recordação e da esperança, heranças ainda de elementos do cristianismo. Propõe o autor, que escreveu muito no pós-guerra, que a Didática da História abarque uma reflexão mais ampla, que pense o passado a partir da experiência e da expectativa.

A experiência seria o passado tornado presente; aquilo que se sabe do passado. Evidentemente, a experiência é única para cada grupo social e para cada indivíduo: “(...) a história é desde sempre concebida como conhecimento 
de experiências alheias" (KOSELLECK, 2006, p. 310). Dessa maneira, caberia investigarmos, como as experiências sociais dos alunos, isto é, suas vivências, constituiriam suas opiniões sobre o passado.

Assim como a experiência, a expectativa seria o futuro tornado presente. Mas não como mera profecia, e, sim, como uma tendência advinda de algum conhecimento dos processos históricos: “... a expectativa se realiza no hoje, é futuro presente, voltado para 0 ainda-não, para o não experimentado, para 0 que apenas pode ser previsto." (Ibidem, p. 310) No caso de alunos da Educação de Jovens e Adultos, seria interessante pensar se as possíveis expectativas que eles teriam em relação à sua vida ou ao país se relacionam com a visão que têm do passado da sociedade, da família, do bairro, etc.

A expectativa dos sujeitos nunca se confirma completamente, e quando se torna experiência, seu resultado dificilmente é o que se esperava. Por outro lado, aos sujeitos que prescindem do conhecimento do passado, faltam instrumentos para pensar as expectativas futuras. A vivência de novas experiências não só alarga o horizonte de expectativas, mas pode inclusive fazer abandonar um projeto e vislumbrar outro futuro (Ibidem). Assim, afirma o autor:

\footnotetext{
Minha tese afirma que na era moderna a diferença entre experiência e expectativa aumenta progressivamente, ou melhor, só se pode conceber a modernidade como um tempo novo a partir do momento em que as expectativas passam a distanciar-se cada vez mais das experiências feitas até então (KOSELLECK, 2006, p. 314).
}

Nas sociedades tradicionais, aquilo que os sujeitos esperavam que acontecesse no futuro era baseado na tradição, pois só se podia ter expectativa sobre o que já ocorrera. A partir das diversas rupturas e revoluções desde a passagem da Idade Média para a Idade Moderna, cristaliza-se a noção de progresso no século XVIII, de modo que no século XIX há a clara percepção (nessa perspectiva) de que há países mais "avançados" e outros mais 
"atrasados", de que há classes sociais na retaguarda, e outras na vanguarda do processo histórico. O "horizonte de expectativas" se desconectara do "espaço de experiências" (KOSELLECK, 2006). Esse fenômeno pode ser percebido, por exemplo, no caso de alunos migrantes, provenientes de zonas rurais, que têm vindo nas últimas décadas trabalhar em grandes centros industrializados, ocasionando em uma possível ampliação do seu "horizonte de expectativas", em relação à sua vida no interior do país.

Desde a Revolução Francesa, uma série de projetos políticos, nascidos como ideias ou utopias, se tornaram experiências ao longo dos séculos XIX e XX. Quando a expectativa de um projeto político se torna experiência, e nunca dá conta de construir concretamente tudo o que prometia, cria-se uma crise nas sociedades atuais, no que se refere às suas possibilidades futuras.

Para Alves (2014), a partir da modernidade a constituição de diversos tipos de consciência histórica deve ser entendida em um contexto social de transformações constantes e expectativas em relação ao futuro. Para o autor,

A consciência histórica pode ser compreendida, sinteticamente, como a aplicação do pensamento histórico à vida, ou seja, a práxis mediada conscientemente pela razão histórica. [...] Nesse sentido, ter consciência histórica é apropriar-se das operações mentais do pensamento histórico com o objetivo de refletir sobre as experiências vivenciadas por si e/ou pelo(s) outro(s) no decurso do tempo a fim de satisfazer expectativas concebidas no presente ou mesmo criar novas expectativas a serem transpostas no futuro (ALVES, 2014, p. 322).

No entanto, o desafio da Didática da História em pensar a consciência histórica é compreendê-la em uma sociedade que ainda está superando projetos políticos inacabados e em crise desde o século XX até os dias de hoje, e que ocasionaram um perigoso relativismo histórico que, no limite, chega a negar a existência de grandes tragédias do século $X X$. 


\subsubsection{A consciência histórica para além da sala de aula}

Tradicionalmente, a Didática era uma disciplina ocupada com a metodologia de ensino de História e suas implicações práticas na escolarização. Cabe, entretanto, perguntarmo-nos acerca da relevância ou não do conhecimento histórico, e, nesse sentido, para que se ensina História, particularmente para jovens e adultos.

Bergman (1985) defende que a tarefa da Didática da História é investigar o que ele chama de "consciência histórica", ou seja, o que os sujeitos apreendem, o que poderiam saber e o que deveriam saber sobre História no seu contexto sócio-histórico. Nesse sentido, o ensino de História ao longo da escolarização dos sujeitos seria um dos principais contextos de constituição da consciência histórica, mas evidentemente não o único. Alunos como os da EJA, ao retornarem à escola, eventualmente se deparam com uma História bem diferente daquela que já sabem previamente através dos movimentos sociais e culturais, das igrejas, dos meios de comunicação, das tradições da família, da história do bairro, etc.

Por isso, para o autor, a Didática não estudaria apenas as formas de transmissão de conceitos históricos, mas também os seus significados culturais. Para o autor, a tarefa reflexiva da Didática é estudar justamente de que maneira os sujeitos, nas práticas cotidianas, dão significados à história, respondendo a necessidade e inquietações que, na verdade, partem do presente.

Para Bergman, a Didática da História é uma área da produção do conhecimento Histórico e tem como objetivo problematizar a constituição da consciência histórica, que é parte da identidade dos sujeitos. Para o autor,

A Didática da História procura também explicitar os pressupostos, condições e metas da aprendizagem na disciplina específica da História, os conteúdos a serem transmitidos, os métodos e as categorias e a possibilidade da estruturação dos conteúdos a partir das categorias 
didaticamente escolhidas na Ciência Histórica e analisa também as técnicas e materiais de ensino e as várias possibilidades da representação da História, seja no ensino ou nos ambientes fora da escola (BERGMAN, 1985, p. 31).

No entanto, para perceber empiricamente os resultados do Ensino de História, precisaríamos de mais pesquisas. Isso porque a consciência histórica é anterior à escolarização, advindo das experiências culturais dos sujeitos e não necessariamente apenas do ensino. A Didática se questiona justamente sobre as condições de consciência histórica dos sujeitos, que significados os sujeitos concretos atribuem à ciência histórica:

\begin{abstract}
Na medida em que se investiga o significado e a importância do mundo do vivido fora das instituições científicas e escolares, sua formação e qualidade e seus efeitos para a formação da consciência histórica, a Didática da História dá uma contribuição fundamental para o conhecimento daquele fator subjetivo transmitido socialmente, que está até um certo grau presente nos procedimentos epistemológicos de cientistas e estudantes, envolvidos em reconstruir a ação e o sofrimento humanos do passado em vários níveis. Ela pesquisa, portanto, com intenção didática aqueles fatores epistemologicamente influentes do mundo do vivido extracientífico e extra-escolar, que a História sistemática reflete num nível teóricoepistemológico (Ibidem, p. 32).
\end{abstract}

\begin{abstract}
A Didática da História estudaria inclusive de que forma o envolvimento ou pertencimento dos sujeitos sociais como alunos jovens e adultos em movimentos sociais, culturas, instituições constituiriam a sua consciência histórica. Nesse sentido, para o autor, o estudo sobre o contexto escolar e as práticas e discursos das aulas de História são importantíssimos, embora 0 contexto escolar não encerre as possibilidades de saber histórico que circulam nas sociedades.
\end{abstract}

Assim, entre outras coisas pode-se afirmar que 
O ensino de História elabora e transmite conhecimentos e percepções, contribuindo, destarte, para a formação de convicções que permitem aos alunos uma orientação na sua respectiva sociedade que é consistente e, ao mesmo tempo, resistente até certo grau às mudanças e aberta para novas experiências e perspectivas no futuro. A tarefa da Didática de História, portanto, consiste em indicar critérios para a seleção dos conteúdos. Estes devem ser tratados com os métodos da racionalidade disciplinada do conhecimento histórico cientificamente elaborado e ser aptos para a formação de uma auto-identidade histórica consistente nos alunos (BERGMAN, 1985, p. 37).

A História é, nessa perspectiva, considerada uma ciência. Não da mesma maneira que as ciências exatas ou biológicas, mas no sentido de que é um campo do conhecimento sistematizado, que não trabalha aleatoriamente com seus dados, mas que os analisa a partir de certos pressupostos teóricometodológicos. O historiador produz uma reflexão racionalizada sobre 0 passado e a Didática da História busca estudar não só os caminhos de constituição social da consciência histórica nos sujeitos, mas inclusive apontar que escolhas deveriam ser feitas no ensino, inclusive de EJA, para uma melhor compreensão dos sujeitos acerca de sua história. As implicações dessas escolhas são profundas, pois são elementos constitutivos da consciência histórica e da própria identidade desses alunos em seu contexto sóciohistórico.

\subsubsection{O conhecimento vicário e o Ensino de História}

A partir de reflexões que dialogam com a Filosofia da História, Paul Lee (2011) tem se preocupado com a relação que os indivíduos têm com o seu passado, como constroem esse conhecimento histórico e como a concepção de passado pode abrir possibilidades para pensarmos as sociedades nos próximos anos. O passado seria algo do qual não se pode escapar, pois ajuda os indivíduos nas suas relações com o mundo físico e social. As instituições e os conceitos possuem um passado; conforme são acionados concretamente ou 
ideologicamente no cotidiano, é como se os indivíduos acionassem também uma versão do passado, ou aquilo que entendem por uma História particular.

O passado seria algo não-presente, mas que se torna inteligível pela História. Evidentemente, essa mediação entre passado e presente realizada pelo campo do conhecimento histórico depende das teorias a ele relacionadas e das intenções e interesses a ele ligados.

O fato de o passado ter ficado para trás não o tornaria irrecuperável; ao contrário, ele se tornaria inteligível pela mediação do conhecimento histórico. $\mathrm{O}$ passado estaria, de certa maneira, "morto", trazido de forma selecionada pela História. O problema estaria no fato de que o passado corre o risco de ser instrumentalizado para a validação de determinadas práticas e formas de poder que necessitam de legitimidade no presente. Por isso, para Lee,

\begin{abstract}
Sem história, o passado serve meramente a interesses práticos e assim, em um importante sentido, nós seríamos destituídos de nossa própria experiência. Para a pesquisa histórica, é simplesmente uma investigação racional do passado e, desde de que nós não podemos escapar do passado, nós temos que procurar o melhor conhecimento que pudermos obter sobre ele (LEE, 2011, p. 25-26).
\end{abstract}

Segundo o autor, esse conhecimento histórico pode ser construído na escola a partir da utilização de evidências, auxiliando o aluno a se apropriar da História. Mesmo assim, há quem acuse a mera apresentação de evidências como um conhecimento escolar desinteressado e pouco útil para a vida futuras das crianças.

Essa busca da História, a partir de procedimentos teórico-metodológicos, constituiria a busca racional pelo passado. Nesse sentido, a importância do ensino de História na educação básica é enorme, pois propiciaria justamente a mediação dos alunos enquanto sujeitos sociais com os processos sociais pelos quais sua sociedade tem passado ao longo do tempo, fornecendo-lhes instrumentos para que se vejam como sujeitos históricos. Cabe, então, 
perguntar: até que ponto a História deve "servir" para alguma coisa? Ela ainda tem lições a ensinar?

A verdade é que, apesar de parecer confortante, dificilmente haveria leis generalizantes na história que pudessem afirmar qualitativa e quantitativamente que, acumulados uma série de eventos comuns, o resultado do processo será sempre aquele que se espera. Basta que se aprofunde a pesquisa sobre qualquer tema histórico e se verificará que as variantes são tantas e tão complexas que dificilmente o conhecimento histórico conseguiria construir, a partir daí, generalizações absolutas do processo histórico. "Não há leis para a derrubada de reis".

Mesmo assim, de alguma forma os historiadores tendem a utilizar leis generalizantes implícitas em suas explicações, o que em si não só não é de todo incorreto, mas até certo ponto necessário. Isso porque, apesar de não haver leis naturais e universais para os processos históricos, é evidente que nos processos de mudança e permanência das sociedades ao longo do tempo há razões e causas para determinado evento ter se desenrolado de uma maneira e não de outra. Para o autor,

O conhecimento histórico pode ser considerado como (entre outras coisas) uma experiência vicária: ela aponta para o que pode ser esperado, enquanto que faz-se evidente que o que é esperado é, raramente, como acontece (LEE, 2011, p. 35).

Dessa forma, para Lee, apesar de a História não ser a "mestra da vida", tampouco é inútil para a vida social dos indivíduos. A experiência vicária com a História possibilitaria a apropriação de um conjunto de conhecimentos acerca do passado que ampliaria a compreensão dos processos presentes (justamente pela sua relação com o passado) e abriria o campo da tomada de decisões, inclusive políticas. A História indicaria um olhar sobre o que ocorreu e sobre o que poderia ocorrer: 
A História diz respeito ao estudo do passado e não do futuro. Mas algum conhecimento sobre o passado nos dá um alcance (mesmo que ligeiro) sobre o futuro. Esse alcance não é fortalecido pela tentativa de fazer da história uma fonte pseudocientífica de predições: ela somente tem alguma coisa distinta a oferecer quando nos reportamos a ela. [...] O que está sendo colocado é que um homem com um conhecimento da história estará situado não mais que um homem carente desse conhecimento, mas do que ele próprio estaria se não tivesse esse conhecimento (LEE, 2011, p. 37).

Os alunos da EJA que, pelo estudo do conhecimento histórico, entram em contato com a multiplicidade de culturas, formações sociais, estruturas políticas, processos de ruptura e continuidade, sem dúvida, contam com elementos importantes para pensar a sua própria vida. A experiência vicária seria, a partir do conhecimento histórico, a possibilidade de os sujeitos do presente colocarem-se em outro contexto histórico-cultural:

A experiência vicária, que é aprendida no ensino de história, estimula a imaginação e expande a concepção do educando do que é ser humano e, assim, do que ele ou ela é ou pode vir a ser (LEE, 2011, p. 40).

\subsubsection{A constituição da consciência histórica em sala de aula}

Eventualmente, os alunos da EJA entram em contato com a História de maneira sistematizada na escola. O conhecimento histórico que a escola traz difere do acadêmico, pelo seu próprio contexto de produção social:

Se algumas pesquisas iniciais foram baseadas na relação direta entre história acadêmica e história ensinada na escola, outras - aí incluídas as minhas próprias - afirmaram e analisaram a distância e a distorção entre elas e apontaram 
para a existência de um conhecimento sobre o passado e de um como-fazer sobre história criada pela escola e para a escola (TUTIAUX-GILLON, 2011, p. 17).

A transferência do conhecimento histórico, da academia à escola, passando pelos livros didáticos e formação de professores, é feita de forma indireta e conflituosa. A escola sofre a pressão das políticas públicas e das propostas curriculares, e ainda que os sistemas de ensino fornecessem condições adequadas de estudo, seu objetivo não é tornar os alunos historiadores.

A necessidade de se pensar a Didática da História surgiu ao longo do século $X X$, quando cada vez mais a educação pública foi se universalizando e um enorme contingente de alunos, proveniente das camadas populares chegou às salas de aula, expondo a inadequação da escola tradicional e seus modelos de ensino com relação às necessidades da população. Ao mesmo tempo, a própria História como campo do conhecimento passou por notáveis avanços em seus procedimentos teórico-metodológicos, notadamente com a Escola dos Annales $^{13}$ : "Assim, a necessidade de mudança da história ensinada na escola se tornou forte por conta tanto dos conteúdos quanto dos estudantes" (TUTIAUX-GILLON, 2011, p. 19).

No contexto francês, Tutiauz-Gillon (2011) percebeu em suas pesquisas que grande maioria dos professores adotava aulas expositivas como a principal metodologia de ensino; mesmo nas interações dialógicas, a margem daquilo que o aluno está autorizado a responder é bem pequena. Ao se aprofundar na formação dos docentes, percebeu que nos cursos de preparação para o magistério, até a década de 1990, a Didática da História correspondia a dez por cento da carga horária da formação dos futuros professores de História.

\footnotetext{
${ }^{13}$ Fundada durante a Grande Depressão em 1929 por Lucien Febvre e Marc Bloch, a chamada "Escola dos Annales" foi um movimento historiográfico que orbitava em volta da revista Annales d"histoire économique et sociale e que foi muito produtivo ao longo do século XX.
} 
Segundo a autora, cria-se, assim, uma contradição. Por um lado, impera na educação a visão de que a História acadêmica é a produção do conhecimento histórico legítima, a ser assimilada e transposta ao contexto escolar. O professor de História, nessa divisão do trabalho, seria o responsável pela reprodução do conhecimento, apresentado aos alunos para que eles "absorvam" o conteúdo da melhor maneira possível. Por outro lado, a produção acadêmica não chega de forma eficaz na escola, mas apenas de maneira indireta. Os debates acerca dos conceitos teórico-metodológicos discutidos na academia ou não se fazem presentes na sala de aula, ou chegam de forma quase irreconhecíveis.

Para a autora, a partir dos anos 1970 e 1980, proliferaram as pesquisas construtivistas que consideravam o conhecimento dos alunos acerca dos temas históricos. Iniciou-se na França um interesse sobre como os alunos se apropriam de determinados conceitos, o que compreendem das aulas de História. Segundo a autora, é interessante como alunos tendem a personificar conceitos abstratos:

Os resultados mostram como os estudantes atribuem conteúdo material e familiar a conceitos abstratos, personificando, por exemplo, o termo monarquia por Luis XIV, e a imagem do Roi Soleil e, assim, descobrindo outros tipos de monarquias por comparação àquela absoluta (TUTIAUX-GILLON, 2011, p. 27).

Essas pesquisas sugerem que a princípio os alunos não se apropriam dos conceitos históricos de maneira abstrata e generalizante, aplicáveis ou não a outras situações segundo a sua lógica interna. Ao que tudo indica, os alunos associam o conceito abstrato em primeiro lugar a um caso exemplar (ou à sua antítese, como nas oposições ditadura e democracia), para só então, pela comparação, verificar se o conceito se aplica ou não a outras realidades.

Outra característica da maneira pela qual os alunos se apropriam de conceitos históricos é relacioná-los a valores ou conclusões morais: 
Os alunos usam de analogias e metáforas, observam responsabilidades pessoais (indivíduos, mas também Estados e grupos agindo como personalidades), se utilizam de teorias do senso comum (ambição por poder, alegações por igualdade e justiça, desejo de riqueza), assim como do conhecimento aprendido na escola (TUTIAUX-GILLON, 2011, p. 28).

Embora seja evidente que o conhecimento histórico traz algum julgamento moral sobre o passado, o que se verifica aqui é a tentativa de compreensão do passado não a partir da sistematização racional de conceitos (classes sociais, mentalidades, curta e longa duração, etc.), mas sim através de uma espécie de narrativa histórica, com enredo, personagens, final portador de uma lição a ser aprendida com determinados episódios históricos.

Essas duas características do pensamento dos alunos franceses apontadas por Tutiaux-Gillon (2011) exemplificam como nas aulas de História o limite entre o senso-comum e o conhecimento acadêmico é de difícil precisão. Eles se influenciam e se contaminam o tempo todo. Poder-se-ia afirmar que o conhecimento acadêmico é um importante elemento apresentado aos alunos que Ihes ajuda a pensar diversos conceitos da História. Ao mesmo tempo, os alunos demonstram pensar a História a partir de outros elementos que não os estudados na escola, e essa espécie de senso comum pode sobreviver (embora não sem transformações) ao longo da vida escolar dos sujeitos. Há uma dinâmica nos processos de pensamento dos alunos, que vai e vem entre uma ponta e outra constantemente.

Esse conflito entre senso comum e conhecimento acadêmico pode se dar tanto porque as metodologias de ensino são pouco interessantes e desafiadoras para os alunos, quanto porque as questões que surgem a partir das representações dos alunos são bastante complexas e excedem a capacidade da escola de, atualmente, lidar com essas questões. Quando se fala em senso comum, não se está meramente dizendo que esse conhecimento é inferior ao acadêmico, mas que faz parte das representações 
sociais e da memória coletiva, com as quais o ensino de História deve interagir em sala de aula:

Os professores lidam, entretanto, com uma competição de memórias implícitas ou explícitas, com relação à escravidão, à colonização, imigração e genocídios. Tanto suas atitudes quanto a de seus alunos e a maneira como eles conseguem ensinar essas questões tem sido objeto de investigação (TUTIAUX-GILLON, 2011, p. 30).

Dessa maneira, a Didática da História não apenas deve levar em conta as situações de ensino-aprendizagem em sala de aula. As mudanças históricas do tempo presente, como crises econômicas, grandes fluxos migratórios, guerras, conflitos culturais, etc. também constituem a dinâmica conflituosa da sala de aula, sobretudo nas aulas de História. Os sujeitos históricos ali presentes trazem para a aula suas demandas, desafiando cada vez mais a História que se pretende ensinar.

Lautier (2011) destaca o caráter de construção social no conhecimento histórico escolar. Os livros didáticos, bem como as estratégias de aula dos professores, são meios de popularização de um conhecimento acadêmico, tanto pelo contexto em que estão situados quanto por causa das necessidades dos alunos aos quais se destinam:

\footnotetext{
Estes saberes, nem completamente científicos nem completamente profanos são o produto de uma verdadeira construção. Descontextualizados em relação à sua instância de produção original, reformulados para serem simplificados, revestidos, propostos sob forma de sequências de ensinoaprendizagem nas salas de aula, eles são frutos de uma construção social (LAUTIER, 2011, p. 41).
}

Conforme a autora, o conhecimento acadêmico, quando é transposto para a escola, é pressionado por diversas demandas estranhas a ele e 
familiares ao contexto educacional: a idade dos alunos, a distribuição e a quantidade de aulas de determinada disciplina, a resistência ou aceitação das famílias a certos conteúdos, o tema de maior audiência na tevê, as reivindicações de movimentos sociais. Além, é claro, da influência dos debates historiográficos. Influenciado pelo conhecimento acadêmico, o ensino deve responder a diversas demandas.

As pesquisas de Lautier (2011) têm indicado que os alunos franceses não se indagam sobre quem selecionou determinados acontecimentos como históricos, ou quem é o autor da escrita da História. Tendem a pensar a História a partir de fatos que significam as grandes rupturas, reduzindo a compreensão dos processos históricos a anedotas curiosas e a personificar os acontecimentos nos grandes personagens do passado.

Mesmo assim, para a autora é interessante notar que também há paralelos nos procedimentos de compreensão do passado por parte de alunos e pesquisadores acadêmicos. Ambos se aprofundam a partir do momento que encontram uma questão ou dúvida a ser esclarecida, ambos desenvolvem certa empatia com os homens e mulheres do passado, a fim de compreender as suas razões dentro de determinadas condições sócio-históricas (LAUTIER, 2011).

Nunca é demais ressaltar que o aluno é um sujeito social, pertencente a grupos culturais. A pertença a um grupo the fornece não apenas determinados conhecimentos e saberes, mas sobretudo memórias, que podem ser acionados na aula de História:

São precisamente os fenômenos de mediação entre os saberes individuais e o meio social que é possível (sic) ver em ação nas respostas dos alunos interrogados sobre diferentes temas históricos: os fenômenos de identificação positiva ou negativa, as comparações propostas, não surgem espontaneamente de memórias meramente individualizadas. As respostas reencontram referências comuns e recorrentes, a memória social procura os quadros de pensamento; os valores compartilhados fornecem a tensão, a necessidade, necessária à aprendizagem/apropriação (LAUTIER, 2011, p. 46). 
Segundo a autora, além da cultura e da memória social, a idade dos alunos também é um elemento importante na compreensão que fazem do passado. Segundo a autora, em comparação com as crianças, os jovens parecem ser mais capazes de fazer generalizações e inferências. Podem problematizar com mais profundidade determinadas versões da história, e inclusive questionar a sua própria forma de pensar.

Enquanto isso, aos professores é reservada a tarefa de conjugar o pensamento dos alunos com uma disciplina que possui determinado rigor teórico-metodológico. Como mediar o que os alunos acham de Luís XIV como tirano absolutista, com o próprio debate historiográfico acerca das monarquias no mundo moderno? Nessa luta, conforme a autora aponta, o ensino de História na prática pouco tem se desenvolvido, sendo muito comum - a despeito de os próprios professores serem conscientes dos limites das práticas pedagógicas - o retorno à velha História linear e política, entrecortada pelos grandes feitos institucionais.

Outra contradição do Ensino de História está em seu caráter, ao mesmo tempo de conhecimento sistematizado e de formação cívica:

[...] professores de história são confrontados com uma situação paradoxal. Eles reivindicam um tratamento relacionado ao programa em uma abordagem histórica que exclui a emoção porque a exatidão histórica, assim como a análise objetiva dos documentos permanece a peça central da disciplina, como se isso permitisse aos professores acantonar-se à parte racional desse ensino. Mas a grande maioria das entrevistas efetuadas durante as pesquisas exprime o fato de temas como a exterminação ou as guerras de descolonização não darem lugar a cursos como os outros. Recorre-se a testemunhos, frequentemente comoventes, reconhece-se que estes conhecimentos raramente são submetidos à avaliação (contrariamente aos professores de letras, que se sentem legitimados em avaliar a criatividade levada pela emoção) (LAUTIER, 2011, p. 52). 
Essa dicotomia entre o ensino de uma "ciência" fria, com suas metodologias, e a formação de uma noção de cidadania parece ser constante nas aulas de História, e ainda carece de maiores estudos, pois ambas as tarefas coexistem e constituem a consciência histórica dos alunos.

Outra prática aparentemente comum é a da comparação entre passado e presente. Do ponto de vista teórico, corre-se o risco de um enorme anacronismo, observando o passado com a lógica da cultura atual. Por outro lado, mostra-se um recurso constantemente usado e, até certo ponto eficaz: "Os professores são confrontados e negociam então uma parte de sua legitimidade profissional" (LAUTIER, 2011, p. 53). Outro exemplo de negociação são os conceitos criados pelos professores exclusivamente para as aulas, às vezes ilustrados com exemplos que são rememorados constantemente pelos alunos. Alguns professores demonstram preocupação com o fato de que os alunos parecem lembrar-se mais das anedotas do que do conceito estudado. Por outro lado, alguns teóricos como Marc Bloch já consideravam a possibilidade de algum anacronismo ou simplificação para fins didáticos.

Por isso, embora completamente relacionados, conhecimento acadêmico e conhecimento escolar estão um para o outro como o historiador para o professor de História. E é nas interações da sala de aula que esses papeis serão assumidos pelo professor: "É portanto ao cotidiano da gestão da sua sala de aula que o professor ajusta o melhor possível esta necessidade de coerência que assegura a legitimidade dos seus papeis e das suas práticas" (LAUTIER, 2011, p. 55).

Para Barca (2001), tradicionalmente a ciência cognitiva considerou que a História como área do conhecimento escolar era inadequada para alunos novos, limitados ainda ao pensamento concreto. Nessa perspectiva, os sujeitos apenas alcançariam a maturidade cognitiva para a reflexão sistemática sobre a história por volta dos dezesseis anos, confundindo-se a quantidade de informações factuais ensinados ou decorados pelos alunos como "pensamento abstrato". Para Barca, 
Tais afirmações forneceram, nos anos 70 e 80, argumentos contra a inclusão da História no currículo de escolaridade obrigatória, enquanto disciplina autônoma, substituindo-a por uma área integrada de Estudos Sociais ou Ciências Sociais (como ainda actualmente em Espanha e nos Estados Unidos). Sob influência desta estereotipada concepção de pensamento concreto versus pensamento abstracto, entre alguns professores de História ainda persiste a convicção de que alguns temas históricos (como a Pré-História ou a ldade Média) são de difícil compreensão para os alunos mais novos porque são muito abstratos (BARCA, 2001, p. 14).

Desde os anos 1970, pesquisadores da Didática da História tem empreendido um interessante diálogo com outras disciplinas como a Filosofia da História, a Psicologia e as Ciências Sociais, para aprofundar as investigações sobre o processo de aprendizagem de conceitos históricos por parte dos alunos. Os alunos, particularmente os que tratamos nesse trabalho (jovens e adultos), trazem noções importantes da História ao chegar à escola:

\footnotetext{
O meio familiar, a comunidade local, os media, especialmente a tevê, constituem fontes importantes para o conhecimento histórico dos jovens, que a escola não deve ignorar nem menosprezar. É a partir da detecção dessas ideias - que se manifestam ao nível do senso comum, e de forma muitas vezes fragmentada e desorganizada - que o professor poderá contribuir para as modificar e torná-las mais elaboradas (BARCA, 2001, p. 15).
}

Em seus estudos sobre as noções de História encontradas entre os alunos em contexto escolar, a autora tem demonstrado que são comuns os elementos que poderiam estar relacionados ao positivismo do século XIX, como a ideia de que há uma veracidade por trás dos documentos históricos, ou que o relato de um sujeito que presenciou determinado fato traz mais veracidade a uma narrativa que o de alguém que não esteve em determinado lugar. Em outros relatos, encontram-se também elementos de um relativismo 
excessivo, como se uma narrativa histórica equivalesse a uma narrativa literária ou religiosa, produzida sem metodologia científica.

Por fim, algumas considerações. A sociedade contemporânea recorre constantemente à História para legitimar decisões governamentais, posições políticas, movimentos sociais e culturais. Têm grande influência nesse contexto os meios de comunicação. Nesse sentido, é preciso pensar que a consciência histórica dos sujeitos, particularmente dos alunos da Educação de Jovens e Adultos, é constituída em um contexto sócio-histórico, que ultrapassa muito os limites da escola, e que deve ser mais aprofundadamente estudada nas pesquisas.

O conhecimento histórico que esses alunos apreendem fora da escola costuma ser caracterizado por uma ausência de rigor teórico-metodológico próprio do conhecimento sistematizado. Constitui, porém, muito da identidade dos sujeitos, pois em geral a consciência histórica apreendida em contextos não escolarizados está relacionada ao cotidiano dos sujeitos. Fornece elementos para a maneira como organizam conceitualmente a realidade, legitimam práticas sociais e visões de mundo.

Por outro lado, não se pode menosprezar a importância da escola na constituição dessa consciência. Alunos da EJA costumam ter uma relação conflituosa com a escola, e tendem a achar que o seu conhecimento em relação à História não é válido no espaço escolar. Por outro lado, o conhecimento histórico escolar não é idêntico ao acadêmico; há também vários elementos não acadêmicos que influenciam no conhecimento histórico escolar, como assuntos do momento comentados nas mídias, currículos governamentais, etc. De qualquer maneira, o ensino de História tem a preocupação com a cidadania e não pode prescindir do diálogo com os sujeitos concretos na sala de aula. Poderíamos considerar a hipótese de que a consciência histórica apreendida em um contexto não formal estaria relacionada a uma situação específica, do cotidiano, dizendo respeito àquilo que Vigotski chamava de "conceito espontâneo", ou não sistematizado. Ao passo que a consciência histórica que foi constituída de maneira sistematizada 
pela escola (ainda que seja diferente em sua gênese do conhecimento acadêmico) estaria mais próxima dos "conceitos científicos" ou sistematizados, pelas suas características: pensar o conceito em si (metacognição), pensar a realidade a partir do conceito e avaliar a sua validade, pensar diferentes posicionamentos ou conceitos em alteridade, entre outros.

\subsection{Análise dos episódios: as relações em sala de aula}

Os episódios analisados a seguir ocorreram durante um módulo de aulas de História que durou dois meses e meio, aproximadamente, no primeiro semestre de 2015. Os alunos tinham duas aulas semanais de duas horas e meia. A sala cursava a $3^{\text {a }}$ Etapa, equivalente ao $6^{0}$ ano do Ensino Fundamental, e o planejamento do professor privilegiou a História do Brasil, desde o período colonial até o Império (entre os séculos XV e XIX). As aulas de História ocorriam de manhã; o professor em geral introduzia o tema das aulas e iniciava uma exposição sobre o assunto.

Nas primeiras semanas, as aulas tratavam, sobretudo, da chegada dos europeus, do contato e o subsequente conflito com os povos originários. Ao longo das aulas, percebemos a sequência de assuntos seguindo a ordem tradicional dos chamados "ciclos econômicos" do Brasil: pau-brasil, cana-deaçúcar, ouro e café. Nas últimas semanas do módulo, as aulas passaram a privilegiar o processo de independência da América portuguesa.

Apesar de a interação ser uma constante nas aulas, alguns sujeitos evidentemente acabam se destacando. Nos episódios em questão, são eles:

- O coordenador pedagógico, formado em História, e que eventualmente substituía o professor nas aulas. Ele é negro, aparenta ter aproximadamente 40 anos e é bastante presente na escola;

- Z é a aluna mais velha da sala, aparentando mais de sessenta anos. Relata por diversas vezes ter vindo do interior do Paraná, o que acaba sendo denunciado pelo seu sotaque. É bastante participativa, não se 
furtando de expor suas opiniões, muitas vezes contrárias às do professor. Eventualmente se irrita com os jovens na sala;

- Sol e M são mulheres trabalhadoras, eventualmente participam das discussões com perguntas e comentários, inclusive ajudando os demais;

- San é um dos adolescentes da sala, talvez o mais agitado. Constantemente causa irritação nos colegas pelos seus comentários irônicos e aparentemente inadequados, mas faz falas muito interessantes sobre os temas das aulas. Relatou ter 16 anos, não trabalha e é negro;

- O professor de História é branco, comentou nas aulas estar próximo da aposentadoria. Aparenta ter mais de 50 anos. É paciente com os alunos e se esforça por elaborar narrativas interessantes nas aulas, embora monopolize grande parte do tempo da aula com a sua explicação;

- F é mulher, trabalhadora. Faltou bastante nas primeiras aulas, praticamente começou o curso depois dos demais. Mesmo assim, demonstra ter um conhecimento histórico mais próximo do pensamento conceitual do que boa parte dos alunos;

- R é mulher, pouco se expressa nas aulas e demonstra bastante cansaço pela manhã. Relatou trabalhar de madrugada, o que sem dúvida lhe traz grande desgaste. No quarto episódio, em especial, polemiza bastante com o professor, como se verá a seguir.

Ao longo das aulas, muitos diálogos interessantes foram observados. No entanto, para a investigação a que nos propúnhamos, quatro episódios nos chamaram a atenção para a discussão a respeito da formação do pensamento conceitual nas aulas de História. O critério para a sua escolha foi a maior nitidez com que conseguimos identificar os conceitos que estavam em jogo, bem como as polêmicas e negociações que ocorreram durante o processo de interação entre esses sujeitos em sala de aula. 


\subsubsection{A mediação em sala de aula}

O primeiro tema estudado foi a colonização portuguesa na América, em que se apresentaram os principais elementos teóricos da expansão comercial europeia dos séculos $X V$ e $X V I$ e o conflito entre europeus e os povos originários do continente americano.

$\mathrm{Na}$ aula anterior ao episódio a seguir, os alunos haviam assistido ao filme britânico "A Missão" (1986), que narra a história de um "caçador de índios" do século XVIII que teria se arrependido e se convertido à vida religiosa, integrando um aldeamento jesuíta e auxiliando os índios nos conflitos durante a colonização espanhola na região de Sete Povos das Missões. A conversão de um antigo caçador de índios em jesuíta e seu papel na defesa dos indígenas durante a colonização compõe a suposta "missão", pintada inclusive com exagerado idealismo no filme.

O objetivo do professor era, após algumas aulas teóricas, discutir o impacto da colonização portuguesa na América sobre a população indígena. Ele havia avisado com antecedência que não poderia estar nas duas aulas daquela semana na escola por motivos profissionais. Na primeira houve a exibição do filme, e na outra o coordenador pedagógico, também professor de História, havia substituído o colega. O professor deixou uma orientação de discussões e de atividade a ser aplicada pelo coordenador pedagógico, que envolvia basicamente levantar o que havia sido compreendido pelos alunos a respeito do filme e a leitura de um texto sobre a colonização, seguida de um questionário a ser respondido individualmente pelos alunos no caderno. Não houve grandes preparações prévias à exibição do filme: o professor se limitou a justificar que não estaria na escola naquela semana, mas que os alunos teriam aula normalmente, pois segundo ele, assistiriam a um filme relacionado ao tema das aulas. Na manhã em que ocorreu este episódio específico, parte dos alunos comentava antes do professor chegar que não haviam gostado ou entendido o filme. No episódio, interagem o coordenador pedagógico (CP), a aluna idosa (Z), os adultos M (mulher), R e C (homens) e o adolescente San. 


\section{Episódio 1}

CP (Coordenador Pedagógico): O filme que ontem vocês assistiram, "A Missão". Esse era o nome do filme. O filme acho que é uma produção norte-americana, não vou lembrar exatamente a data dela.

Z(aluna): Precisa copiar o nome do filme?

CP: Não, não precisa copiar não. Não precisa copiar não, pessoal. Estou anotando só pra gente começar a aula de hoje. O que vocês acharam do filme mesmo? Vocês estavam comentando? Acharam o filme polêmico?

(A maioria dos alunos diz que gostou, um ou outro diz que não gostou)

M (aluna): Mais ou menos professor. Por conta da violência daquele filme.

CP: O que é que é a Missão? O que seria a Missão? De acordo com o filme, vocês perceberam o que seria a tal da Missão?

M: A Missão é eles matando uns aos outros. (comentários da sala)

CP: Então olha lá, vamos ver os elementos que vocês viram no filme. Então, no filme vocês falaram que tinha um tal de padre, né? Jesuíta, é isso?

Alunos: Isso.

CP: E aí tem os índios, certo?

R(aluno): Tinha o cara que tava matando?

CP: O cara que tava matando, quem é que estava perseguindo os índios?

Alunos: Portugueses! Jesuítas!

CP: Calma, vamos por partes! Tem o padre jesuíta.

San (aluno): Se eu errar, eu estou chutando, porque eu não entendi o filme, nada.

CP: Tem o índio...

M: O índio!

CP: E tinha um outro personagem que perseguia os índios, não tinha? Ele era um espanhol, e era uma espécie de militar, enfim. Mas ele faz uma espécie de caça e venda de índios. Era tipo um mercenário. Eu não vou lembrar o nome dele, era o personagem do Robert de Niro no filme.

C (aluno). Foi esse mesmo.

San. Não sei de nada não, não assisti o filme. 
CP: Depois ele vira padre, não vira? Depois ele vai junto com os padres. Então você tem a figura do caçador.

San. Eu não assisti, não. Cheguei atrasado.

M. Eu não entendi muito daquele filme não.

San. Eu só vi os índios tomando uns tiro.

CP: No filme, o que é que o índio representa pro padre? Para os padres, no filme, pelo menos, o índio é o quê, pros padres jesuítas? Ele tinha uma relação boa, qual era a relação do padre com o índio?

San. Não era boa não.

Alunos: Era! Cuidava de índio (enfáticos).

CP: O que é que os padres faziam com os índios?

M: Ensinavam.

CP: Ensinavam o quê? É isso? Todo o mundo entende isso? Esse cara aqui, fazia o quê?

Alunos: Caçava os índios, para escravizar.

CP: Para escravizar, vender? É isso? E os índios? Eles ficavam buscando a proteção do padre, da Missão. Agora, vamos ver o que é a tal da Missão. O que era a tal da Missão? Vou falar disso rapidinho, senão a gente não consegue entrar na aula de hoje.

No início da aula, conforme os alunos chegavam à sala e se sentavam, começaram a espontaneamente comentar o filme "A Missão", exibido no dia anterior. O coordenador pedagógico, após chegar e fazer a chamada, inicia um diálogo sobre o filme para utilizá-lo como instrumento para discutir a colonização europeia, e assim trazer alguns conceitos:

- "índio"

- "jesuíta"

- "caçador"

- "missão"

Ele começa com uma pergunta "O que vocês acharam do filme mesmo?" e aparentemente seu objetivo é levantar o que os alunos entenderam, para, a 
partir daí, começar a explicar os conceitos propostos. Os alunos então passaram a destacar os elementos do filme que foram significativos para eles.

Segue-se uma prática muito comum em sala de aula: após a exibição de um filme, o professor (ou no caso quem está no lugar dele) inicia um debate com a turma para que as impressões trazidas auxiliem na construção de determinado conceito. Ocorre que nos primeiros turnos desse episódio os alunos demonstram não estarem seguros quanto aos procedimentos das aulas e às perguntas do coordenador. Logo no início, é possível perceber que a aluna Z (mulher, idosa, do interior do Paraná) e o coordenador discutem rapidamente os procedimentos da aula:

$C P$ : O filme que ontem vocês assistiram, "A Missão". Esse era o nome do filme. O filme acho que é uma produção norte-americana, não vou lembrar exatamente a data dela.

Z: Precisa copiar o nome do filme?

CP: Não, não precisa copiar não. Não precisa copiar não, pessoal. Estou anotando só pra gente começar a aula de hoje.[...]

Aparentemente não ocorre ao coordenador a necessidade de um esclarecimento prévio aos alunos sobre o que deve ser anotado ou não, até porque ele estava substituindo o professor nesse dia. Mas para a aluna, a dúvida era importante, a ponto de interromper o coordenador para resolver o problema (se anotava ou não o que estava sendo escrito na lousa). Aparentemente, a aluna demandava dos professores o ritual da cópia de texto na lousa, muito utilizada sob a justificativa de ser um instrumento (questionável) de alfabetização. O coordenador, então, segue lançando questões para os alunos, demandando deles a atenção na aula.

A escola de alguma maneira espera que determinadas práticas sejam previamente conhecidas por todos os alunos, o que nem sempre ocorre: 
Os alunos se veem com frequência imersos em rituais e procedimentos sem haver captado o objetivo geral do que tem feito, incluídos os princípios e conceitos gerais que as atividades de uma lição em particular estavam destinadas a inculcar-Ihes (EDWARDS; MERCER, 1988, p. 147, tradução nossa).

Muitas vezes, as práticas da escolarização como estão postas acabam sendo incompreendidas pelos alunos, que não são consultados sobre como e $o$ que aprender. Parte-se do pressuposto de que determinados rituais escolares são reconhecidos por todos e dispensam maiores explicações. Por isso, no início do episódio o coordenador pedagógico não esclarece se os alunos devem ou não copiar o texto da lousa no caderno, enquanto a aluna $Z$ demonstra a dúvida quanto ao procedimento da aula.

Em seguida, o coordenador começa questionando os alunos sobre o filme; nas respostas, é possível perceber que há muita confusão por parte dos alunos sobre os papéis de cada sujeito histórico presente no filme (indígenas, jesuítas, caçadores):

CP: O cara que tava matando, quem é que estava perseguindo os índios?

Alunos: Portugueses! Jesuítas!

CP: Calma, vamos por partes! Tem o padre jesuíta.

San (aluno): Se eu errar, eu estou chutando, porque eu não entendi o filme, nada.

No filme, os portugueses e espanhóis estavam caçando indígenas para torná-los escravos, enquanto os jesuítas eram contrários à escravidão. Mas alguns alunos parecem não saber dizer se quem estava perseguindo os índios eram os portugueses ou os padres jesuítas. O coordenador aparentemente percebe que deve ser mais didático e tenta explicar o papel de cada um desses sujeitos históricos. Seguindo o episódio, alguns turnos depois, alguns alunos reafirmam a dificuldade em compreender o filme: 
CP: Depois ele vira padre, não vira? Depois ele vai junto com os padres. Então você tem a figura do caçador.

San. Eu não assisti não. Cheguei atrasado.

M. Eu não entendi muito daquele filme, não.

Dois alunos, novamente $\mathrm{M}$ e o adolescente San, verbalizam problemas na compreensão do filme. A exibição de filmes com temas históricos e a posterior explicação ou debate sobre determinados conceitos a eles relacionados são recursos amplamente utilizados nas escolas, particularmente em aulas de História. Ocorre que, apesar da aparente simplicidade dessa estratégia, ela talvez tenha seja mais familiar para o professor, e não tanto para os alunos. Se considerarmos que estamos falando de alunos da EJA, que nem sempre estão habituados a certas práticas escolares (como a exibição de filmes históricos para fins acadêmicos), ou que possam ter uma relação conflituosa com elas, é possível que o episódio acima tenha iniciado com um descompasso entre as expectativas do professor e a maneira como os alunos lidaram com a atividade. San, por exemplo, estava bastante entretido com o celular durante a exibição do filme, no dia anterior.

A leitura crítica de uma película para fins acadêmicos é uma prática que não é "natural", mas necessita ser construída com os alunos tanto quanto os princípios ou conteúdos a serem ensinados. Para Edwards e Mercer (1988), certas práticas de ensino utilizadas em sala de aula muito comuns a partir dos anos 1970 e identificadas como "construtivistas" partem do princípio de que o professor faça perguntas aos estudantes, cujas respostas são por ele conhecidas previamente, para testar os conhecimentos dos alunos e dessa maneira esperar que eles cheguem, pelo seu próprio raciocínio abstrato, aos significados considerados "corretos". Esse modo de construção de conceitos com os alunos, se por um lado se coloca como uma alternativa a práticas educacionais ditas "tradicionais" que desconsideram os conceitos cotidianos dos alunos, por outro nem sempre produz os resultados desejados. Nesse 
sentido, se os alunos não sabem responder prontamente às perguntas do coordenador sobre o papel dos jesuítas no filme, é porque ainda está sendo construído, no processo das interações em sala de aula, um conhecimento compartilhado (EDWARDS; MERCER, 1988) entre esses sujeitos, a respeito da colonização europeia.

No entanto, ao longo do episódio, em meio às tentativas do coordenador de estabilizar as formas de conhecer a realidade (GÓES; CRUZ, 2006) a respeito do que eram os "jesuítas", a "missão", os "caçadores" ou os "índios", rapidamente os alunos começam a delimitar determinados atributos dos conceitos que estão sendo discutidos. Após alguns turnos em que 0 coordenador tenta explicar, a partir de perguntas e respostas, que os jesuítas eram aqueles que "protegiam" os índios da escravidão e os catequizavam, os alunos parecem começar a se apropriar desse elemento do conceito jesuíta (proteção dos índios) pela maneira como também se tornaram mediadores da discussão com San:

CP: No filme, o que é que o índio representa pro padre? Para os padres, no filme pelo menos, o índio é o quê, pros padres jesuítas? Ele tinha uma relação boa, qual era a relação do padre com o índio?

San. Não era boa, não.

Alunos: Era! Cuidava de índio (enfáticos).

Enquanto nos primeiros turnos, a sala de uma maneira geral, não é unânime sobre a relação dos jesuítas com os indígenas, aos poucos é construído o consenso de que os primeiros, de alguma maneira, auxiliavam os segundos contra a escravidão. Quando o coordenador lança a pergunta a respeito da relação entre eles, e San - que se queixou diversas vezes de não ter entendido o filme - responde que a relação entre os indígenas e os jesuítas não era boa, é veementemente corrigido pelos colegas: "Era! Cuidava de índio!" Ao longo da interação, parte dos alunos começa a operacionalizar conscientemente conceitos como "jesuíta" e "índio" e a relação entre eles. Para 
Vigotski, quando o sujeito deixa de pensar apenas a partir de sua experiência mais concreta, e sim a partir do isolamento de determinados atributos dos conceitos, o pensamento se torna mais estável e passa a ser instrumentalizado de maneira mais consciente pelo indivíduo (VIGOTSKI, 2010). No episódio acima, o atributo "cuidava de índio", referente ao conceito "jesuíta", começou a ser destacado por boa parte dos alunos, a partir da mediação do filme, do professor, e dos próprios colegas.

Para Tulviste (1991), enquanto indivíduos de povos tradicionais pensam basicamente a partir de suas práticas sociais cotidianas, em sociedades industriais modernas o sujeito é constantemente demandado a pensar além de seu contexto mais imediato. A escolarização, por exemplo, elencaria, a partir de metodologias socialmente aceitas como válidas, determinados objetos do conhecimento que nem sempre estão fisicamente presentes na escola. No pequeno trecho da interação em sala de aula acima, percebemos como a escolarização demanda das interações entre os sujeitos em sala de aula a reflexão sobre um conjunto de objetos concretamente ausentes ("jesuíta", "índio"), mas que se tornam o objeto de estudo da sala, destacando-se um atributo específico: o fato de que jesuítas "cuidam" dos índios. A interação entre coordenador e alunos passou rapidamente de uma profusão de opiniões diversas sobre jesuítas e portugueses, até a "correção" enfática e coletiva que os demais alunos deram sobre a fala de San, organizando sentidos do conceito "jesuíta". Isso só foi possível pela mediação do coordenador, da linguagem do filme, da linguagem em sala de aula. Os próprios alunos puderam mediar sentidos e significados do conceito "jesuíta" entre si.

No contexto da escolarização, as interações entre sujeitos e a mediação pela linguagem constituem psiquicamente os conceitos, organizando-os pouco a pouco ao longo do processo de ensino. O papel dos professores é fundamental, pois, em geral, são eles os responsáveis, através da sua orientação nas aulas, por ampliar o repertório dos alunos e construir um conhecimento compartilhado (EDWARDS; MERCER, 1988). Dessa maneira, a escolarização possibilita (ainda que não só ela) condições para que se 
constituam funções psicológicas superiores, como o pensamento conceitual. Em um primeiro momento, porém, essas funções nem sempre estão plenamente desenvolvidas nos alunos, ainda não podem ser operacionalizadas individual e conscientemente por eles. Necessitam, pois, de uma mediação, para que se constituam, em colaboração com os demais sujeitos da sala de aula, novas formas de significação de conceitos da História. Aquelas operações que os sujeitos ainda não conseguem realizar individualmente, mas as realizam conjuntamente pela mediação com parceiros da cultura, constituem a Zona de Desenvolvimento Proximal (ZDP). Referindo-se à ZDP de crianças em idade escolar, Vigotski afirma que

\footnotetext{
Ela é a distância entre o nível de desenvolvimento real, que se costuma determinar através da solução independente de problemas, e o nível de desenvolvimento potencial, determinado através da solução de problemas sob a orientação de um adulto ou em colaboração com parceiros mais capazes (VIGOTSKI, 2003, p. 112).
}

Embora o autor esteja se referindo a crianças, acreditamos que em sua teoria mais geral não estão excluídos os adultos dessa dinâmica entre aprendizado e desenvolvimento em um contexto escolar. No início do episódio, os alunos chegam à sala comentando o filme, mediando interpretações sobre o filme uns com os outros. No entanto, ainda não havia uma intervenção pedagógica consciente nesse momento, que organizasse de maneira sistematizada os elementos compreendidos do filme. Quando o coordenador inicia o debate sobre o filme, parte dos alunos manifesta opiniões diversas e contraditórias sobre a película e sobre a colonização, forçando o coordenador a ter que organizar, na sua fala, os vários sentidos dos conceitos "jesuítas", "índios", "missão" e "caçador". Ao longo do diálogo, parte dos alunos rapidamente começa a se apropriar dessa organização conceitual, a ponto de, na interação com o colega San, explicarem para ele o conceito "jesuíta", por um atributo específico ("cuidava de índio"). Na mediação entre esses sujeitos em cooperação na sala de aula, foi possível começar a construir conceitos da 
História, que, de outra maneira, dificilmente teriam sido constituídos, ao menos sistematicamente dessa maneira.

Nesse episódio, percebe-se que diversos procedimentos utilizados pela escola, de uma maneira geral, como a exibição e posterior discussão do filme, ou a demanda de anotação dos textos em cadernos, geraram alguns mal entendidos entre os alunos, que inicialmente se mostraram um tanto confusos quanto às estratégias de ensino propostas. Mesmo assim, o contexto da escolarização possibilitou, com a participação ativa dos sujeitos, a construção de determinadas práticas sociais e operações mentais, como a atenção dirigida (não era necessário copiar o texto da lousa, mas a atenção durante a explicação era necessária), a apropriação de determinados atributos de alguns conceitos (por exemplo, o de que os jesuítas "cuidavam de índio"), a ampliação de sentidos e significados para reflexões que iam além de sua realidade mais imediata (colonização do Brasil, conflitos entre europeus e indígenas, polêmicas entre europeus sobre a questão indígena), a organização mental desses conceitos (o papel do caçador era capturar o índio, o jesuíta "cuidava") e a construção de um conhecimento compartilhado entre os sujeitos, a partir da linguagem utilizada nas aulas de História.

\subsubsection{Sentidos e significados}

O episódio a seguir ocorreu na mesma aula do episódio analisado anteriormente. O coordenador pedagógico, que desempenhou o papel de professor, por um lado demonstrou familiaridade com o tema da aula, mas por outro aparentou não estar habituado a mediar cotidianamente esses conceitos para os alunos. Embora tenhamos constatado ao longo da pesquisa que no dia a dia da escola os coordenadores pedagógicos eram bastante presentes nas atividades, evidentemente o vínculo da turma com o coordenador no contexto de sala de aula era mais superficial do que com o professor. Talvez o comprometimento do coordenador com a construção das discussões fosse limitada pela transitoriedade da sua situação, talvez os alunos da EJA, longe da 
escola há algum tempo, tenham dificuldade em expor suas opiniões em sala de aula para professores com quem não estão costumados.

De qualquer maneira, seguia a discussão proposta anteriormente pelo professor, a ser mediada pelo coordenador pedagógico, sobre os conflitos entre portugueses e povos indígenas no período colonial, a partir da exibição, na aula anterior, do filme "A Missão" (1986).

No episódio a seguir, interagem quatro sujeitos: o coordenador pedagógico (CP), uma aluna idosa $(Z)$, uma mulher trabalhadora $(M)$ e um adolescente negro (San). O coordenador havia iniciado a aula perguntando a opinião dos alunos sobre o filme; surgiram então vários comentários a respeito do modo de vida dos povos indígenas.

\section{Episódio 2}

$Z$ (aluna): E eles ficaram selvagens, foi falta de convivência com os outros? Porque eles eram selvagens!

CP (coordenador pedagógico): Olha, aí vem outra coisa. O que é ser selvagem, hein?

San (aluno): Comer carne?

Z: Eles não matavam? Se eles encontrassem um português, eles não matavam?

CP: Não necessariamente. Não, não. Não necessariamente, não matavam, não. Quem corria mais o risco de ser morto era o índio, tá!? O que é ser selvagem?

M (aluna): Uma pessoa que vive no mato!

Z: Uma pessoa que não convive com ninguém? Ela fica uma pessoa selvagem!

CP: Mas o índio não tem família? Eles convivem entre eles!

Z: Mas só entre eles lá.

M: Por que no Brasil não tem mais índios?

Z: Mas ai é diferente, não é a convivência dele?

M: Professor, por que não tem mais índio no Brasil?

CP: Por que não tem mais índio no Brasil? Tem índio no Brasil! 
San: Tem! A minha tia é parente de índio, professor.

CP: Nem na tevê você viu índio?

San: Professor, minha família é de uma família de índio!

CP: Oi?

San: Minha tia é coisa de índio.

CP: Olha, pessoal, eu vou entregar um texto pra vocês agora. Vamos ler este texto, e depois a gente vai analisar um pouquinho sobre ele, tá bom?

San: Minha tia tem coisa de índio, professor. Ela tem parte de índio.

CP: Ah, eu já entreguei.

San: Ela é meio de índio, meia normal.

CP: Normal? Como assim, meio normal? O que é ser normal?

San: Normal! Que não é índio. Não é, meio assim, misturado.

CP: Tá vendo? "Selvagem", "normal". A gente tem que tomar cuidado. O que é ser normal? O que é ser selvagem?

Z: Selvagem é assim, por exemplo. Agora os índios já não são, mas naquele tempo, se eles encontrassem um português, alguém assim, eles matavam pra comer.

$C P:$ A palavra selvagem é de quem vive na selva. A palavra selvagem não necessariamente... É óbvio né, falava-se que quem vivia na selva era mais violento. Mas se a gente parar pra pensar...

Z: Selvagem é quem vive na selva, então eles eram selvagens!

$C P$ : Selvagem é quem vive na selva, a palavra selvagem é que vive na selva.

Z: Então eles eram né, porque eles viviam na selva.

CP: Mas não necessariamente quer dizer que ele seja mau, entendeu? Claro que, quando eles falavam "selvagem", eles acreditavam que uma pessoa só por viver na selva, era violenta.

Os diálogos em sala de aula ocorrem no contexto das práticas sociais próprias da escolarização. A instituição escolar autoriza que o professor (ou no caso do episódio acima, quem ocupa seu lugar) paute os temas das interações verbais, para que, partir deles, os alunos se posicionem. Ocorre que muitas vezes os alunos, que estão em uma posição de "aprendizes", disputam os sentidos e significados daquilo que é dito, chegando por vezes a conduzir 
alguns pontos da pauta da aula ou até mesmo invertê-los. No episódio acima, Z dá o tom das interações ao trazer para a discussão o que para ela é o caráter "selvagem" dos povos indígenas. A partir dessa colocação, o coordenador aparentemente se sente incomodado com a palavra "selvagem" e se vê obrigado a problematizar a fala da aluna (ele repete em três outros turnos a pergunta: "O que é ser selvagem?"). Os demais alunos também respondem, à sua maneira, à pergunta do coordenador e ao comentário de Z:

Z: E eles ficaram selvagens, foi falta de convivência com os outros? Porque eles eram selvagens!

CP (coordenador pedagógico): Olha, aí vem outra coisa. O que é ser selvagem, hein?

San (aluno): Comer carne?

Z: Eles não matavam? Se eles encontrassem um português, eles não matavam?

CP: Não necessariamente. Não, não. Não necessariamente, não matavam, não. Quem corria mais o risco de ser morto era o índio, tá!? O que é ser selvagem?

M (aluna): Uma pessoa que vive no mato!

Ao iniciar o debate sobre a suposta natureza "selvagem" dos indígenas, $Z$ abriu um espaço para a participação dos demais sujeitos (alunos e coordenador) no diálogo sobre o que é ser "índio" e "selvagem". Para Bakhtin, é em interações como essa que se constituem os valores e visões de mundo, a partir do conjunto de discursos ideológicos produzidos socialmente. Segundo o autor,

Os signos só podem aparecer em um terreno interindividual. Ainda assim, trata-se de um terreno que não pode ser chamado de "natural" no sentido usual da palavra: não basta colocar face a face dois homo sapiens quaisquer para que os signos se constituam. É fundamental que esses dois indivíduos estejam socialmente organizados, que formem um grupo (uma unidade social): só assim um sistema de signos pode constituir-se. A consciência individual não só nada pode explicar, mas, ao 
contrário, deve ela própria ser explicada a partir do meio ideológico e social (BAKHTIN, 2014, p. 35).

A organização dos sujeitos por dentro da instituição escolar garante um ambiente "não natural", em que se dão as possíveis interações sociais e suas (re)criações. Z traz elementos ideológicos por trás da palavra "selvagem" marcados inclusive por uma certa intolerância contra os povos indígenas, mas que reflete um posicionamento muito comum na sociedade. $O$ coordenador ensaia um posicionamento contrário ao da aluna, ao questionar a palavra "selvagem". Os alunos M e San escutam a colega e aparentemente elaboram sua própria versão do que seria ser "selvagem" ao darem sua opinião: "comer carne" (humana) e "viver no mato". Foi, portanto, pelas interações em sala de aula que a palavra "selvagem" pôde ser trazida com seus valores sociais, mas também pôde ser reelaborada, repensada, colocada ao lado de outros conceitos, como se verá a seguir.

Seguindo nossa análise, o conceito de "selvagem" é trazido por Z para ajudar a pensar um conceito mais central na discussão da aula, pautado pelo coordenador: índio. Ao longo do episódio, após $Z$ adjetivar o índio como "selvagem", e em meio à polêmica que se abriu entre $Z$ e o coordenador, $M$ traz outra pergunta sobre os indígenas, sugerindo outro ponto a ser debatido. Ao perguntar "Por que no Brasil não tem mais índios?", ela aparentemente parte do pressuposto de que os povos indígenas estavam no passado, mas de alguma maneira não chegaram aos dias atuais. É possível que essa opinião recorrente no senso comum tenha sido corroborada de alguma maneira pelas cenas de guerra do filme "A Missão", que narra a derrota dos povos indígenas durante a colonização europeia. O comentário de $\mathrm{M}$ surpreende o coordenador, que tentava ainda responder aos questionamentos de $Z$, e recorre à autoridade dos meios de comunicação para problematizar o ponto de vista de $\mathrm{M}$, perguntando se ela nunca tinha visto indígenas na televisão; $M$ não parece ter dado muito valor para esse argumento. Em meio ao diálogo, San rebate M, afirmando que há sim índios hoje no Brasil, mas não os da tevê: 
M: Professor, por que não tem mais índio no Brasil?

CP: Por que não tem mais índio no Brasil? Tem índio no Brasil!

San: Tem! A minha tia é parente de índio, professor.

Em apenas três turnos, a palavra "índio" recebeu três sentidos diferentes. Os três sujeitos acima, ao falar e pensar o conceito "índio", dirigemse uns aos outros e à sala como interlocutores, demonstrando distintas compreensões da palavra. Para Bakhtin,

$\mathrm{Na}$ realidade, toda palavra comporta duas faces. Ela é determinada tanto pelo fato de que procede de alguém, como pelo fato de que se dirige para alguém. Ela constitui justamente o produto da interação do locutor e do ouvinte. Toda palavra serve de expressão a um em relação a outro. Através da palavra, defino-me em relação ao outro, isto é, em última análise, em relação à coletividade (BAKHTIN, 2014, p. 117).

Alunos e coordenador demarcam posições uns em relação aos outros a partir dos sentidos que atribuem à palavra "índio" nessa interação em sala de aula. M perguntou "por que não havia índios hoje no Brasil", San em seguida parece querer responder a ela que há índios sim. No entanto, diz isso ao coordenador esperando talvez que a sua autoridade auxilie o aluno perante a sala. Em quatro outros turnos repete que sua família ou sua tia possui ascendência indígena, sendo ignorado em três deles. San é adolescente, considerado um aluno agitado e irritando constantemente os mais velhos com seus comentários irreverentes, nem sempre dentro do tema da aula. Parece querer insistir para contribuir com o debate, com uma referência pessoal que contrasta com os comentários de M: na sua vivência cotidiana, tem parentes indígenas. Dá a entender que, para ele, não só há índios hoje no Brasil, como eles estão próximos, fazem parte da família. Dessa maneira, não há no 
episódio falas isoladas, mas opiniões bem definidas e direcionadas aos demais sujeitos. Para Bakhtin,

[...] a palavra não é somente o signo mais puro, mais indicativo; é também um signo neutro. Cada um dos demais sistemas de signos é específico de algum campo particular da criação ideológica. Cada domínio possui seu próprio material ideológico e formula signos e símbolos que lhes são específicos e que não são aplicáveis a outros domínios. O signo, então, é criado por uma função ideológica precisa e permanece inseparável dela. A palavra, ao contrário, é neutra em relação a qualquer função ideológica específica. Pode preencher qualquer espécie de função ideológica: estética, científica, moral, religiosa (BAKHTIN, 2014, p. 37).

Dessa maneira, palavras como "índio" e "selvagem" acabam sendo utilizadas dentro de discursos ideológicos que inclusive são conflitantes entre si. Para melhor compreensão, separamos aqui três concepções encontradas sobre o conceito "índio" por parte dos alunos nesse episódio:

1) o índio era "selvagem", violento, não convivia com "os outros" (os não índios) e "comia" seus inimigos (Z);

2) o índio fez parte da história, não existe mais atualmente (M);

3) o índio é um parente, está na família, mas ele não é "normal" (San).

Essas opiniões refletem noções sobre os indígenas existentes antes mesmo da própria interação em sala de aula. São trazidas para a aula pelos alunos, à sua própria maneira. Foram constituídas a partir de relações sociais mediadas em contextos anteriores ao retorno à escola na Educação de Jovens e Adultos. São elaborações que refletem ao mesmo tempo noções socialmente aceitas sobre o conceito "índio" (ainda que questionáveis), e são colocadas à prova na interação entre interlocutores, que os reelaboram no contexto de uma aula de História. 
São elementos dos conceitos cotidianos ou "espontâneos" de que falava Vigotski (2010); adquiridos em geral fora de um contexto de educação formal, sem necessariamente uma sistematização. A partir deles, os alunos se apoiam para interagir com o conhecimento sistematizado, demandado ao longo da escolarização. Para Oliveira,

Com referência à organização conceitual seria, pois, razoável propor a hipótese de que um modo de pensamento mais dependente dos dados perceptuais imediatos e do contexto concreto operaria com formas mais fragmentadas de organização conceitual, sujeitas à influência de circunstâncias específicas e a peculiaridades da história individual, com menor pressão em favor da consciência interna e da estabilidade no correr do tempo (OLIVEIRA, 2009, p. 179).

Os conceitos cotidianos são, portanto, mais relacionados às experiências e vivências imediatas dos sujeitos. Trazem elementos de conceitos sistematizados, mas eles estão fragmentados e não organizados coerentemente. Quando o sujeito pensa por conceitos cotidianos, tende a não separar o referente do conceito. Os sentidos elaborados pelos alunos sobre 0 conceito "índio" foram constituídos em seu cotidiano e em suas experiências individuais, mediados por relações sociais e formas de produção de conhecimento não sistematizadas. Talvez para a geração de uma aluna idosa, branca, do interior do Paraná, como Z, Ihe tenham ensinado que os índios são "selvagens". Para M, possivelmente a carga de trabalho imposta a uma mulher da periferia seja tão grande que lhe impeça de acompanhar cotidianamente as notícias sobre indígenas nos jornais. Para a experiência do jovem San, os indígenas são próximos, fazem parte da sua família. Quando esses alunos dizem que o índio é "selvagem", "ausente nos dias atuais", ou "parte da família", não estão pensando os significados desses conceitos em si, mas em relação a valores culturalmente estabelecidos em práticas societárias cotidianas. 
Diante de tantos posicionamentos diferentes entre si por parte dos alunos, e diferentes das noções que previamente deveriam ser debatidas, o coordenador pedagógico, no papel de professor, parece não dar conta de responder a todos os alunos. Ao longo do episódio, as três noções identificadas por parte dos alunos sobre o que seria o "índio" aparecem simultaneamente nos diálogos, impedindo que o coordenador medeie conscientemente todos esses sentidos com o conjunto dos alunos. Ao mesmo tempo, ele parece não ter a intenção de que cada opinião dos alunos seja discutida coletivamente pela sala. Isso pode ter acontecido pela dinâmica da aula (muitas pessoas falando ao mesmo tempo, pouco tempo para as discussões, atividade combinada previamente com o professor da turma para ser aplicada naquele dia), ou devido à disputa ideológica que emergiu sobre o papel dos povos indígenas na história que o coordenador não esperava e para a qual não estivesse efetivamente preparado. Mesmo assim, seus questionamentos buscaram problematizar com os alunos o conceito "índio", tomando o cuidado de não constranger os alunos por alguma opinião considerada politicamente incorreta ou metodologicamente equivocada pelas ciências humanas. Podemos encontrar dois posicionamentos do coordenador ao longo do episódio:

1) O coordenador pedagógico questionou a adjetivação dos alunos do índio como "selvagem" ou "não normal", mas não desqualificou a opinião dos alunos;

2) Ele tentou mudar de assunto, propondo outra etapa da aula com a leitura de um texto;

3) Ele não organiza os sentidos apresentados sobre o conceito "índio" com elementos do campo do conhecimento da História, mas propõe outro sentido para a palavra "selvagem".

Aparentemente, sua tentativa foi a de se filiar a uma voz social que legitima os modos de vida dos povos originários como possibilidades de sociabilidade, alternativos ao que se concebe como a sociedade ocidental, marcadamente pautada pelo eurocentrismo. Ele faz isso questionando algumas vezes: "O que é ser selvagem?". 
Também problematiza com a aluna $Z$ a respeito da ideia de que "selvagem" seria alguém que não convive com "ninguém", entendendo com isso ninguém da sociedade urbanizada ocidental:

CP: Não necessariamente. Não, não. Não necessariamente, não matavam, não. Quem corria mais o risco de ser morto era o índio, tá!? O que é ser selvagem?

Z: Uma pessoa que não convive com ninguém? Ela fica uma pessoa selvagem!

CP: Mas o índio não tem família? Eles convivem entre eles!

Z: Mas só entre eles lá.

Aqui o coordenador questiona a afirmação da aluna $Z$ de que $o$ índio "não convive com ninguém", que considera implicitamente que "ninguém" refirase aos não índios, os ditos "civilizados". Em seguida, quando San indica que sua tia possui ascendência indígena, ele afirma implicitamente que não ser índio seria o "normal", e é questionado pelo professor:

San: Ela é meio de índio, meia normal.

CP: Normal? Como assim, meio normal? O que é ser normal?

San: Normal! Que não é índio. Não é, meio assim, misturado.

CP: Tá vendo? "Selvagem", "normal". A gente tem que tomar cuidado. O que é ser normal? O que é ser selvagem?

O coordenador busca, nos turnos acima, problematizar o conceito de "normal" com S, questionando ao final a utilização das palavras "selvagem" ou "normal" para qualificar índios e não índios. Nesse episódio todo, há um esforço por parte do coordenador em questionar pelo menos três conceitos específicos: "índio", "selvagem" e "normal", sendo os dois últimos utilizados pelos alunos na verdade para adjetivar o primeiro. Embora não haja uma 
grande sistematização dos conceitos do ponto de vista do método por parte do coordenador, pode-se dizer que o questionamento dele em relação a essas palavras (índio, selvagem, normal) demanda dos alunos ao longo do episódio que pensem, a partir das suas experiências e elaborações, os conceitos em si. Para Oliveira,

\begin{abstract}
A presença de mecanismos de pensamento a respeito do pensamento daria ao sujeito a possibilidade de acesso consciente à rede de relações que articulam esses conceitos entre si. Com base em operações metacognitivas, seria provavelmente possível que o sujeito tornasse explícito, para si próprio e para os outros, as relações entre seus conceitos e teorias (OLIVEIRA, 2009, p. 178).
\end{abstract}

Ao questionar os alunos sobre as palavras por eles utilizadas, como "selvagem" e "normal", o que o coordenador faz é deslocar o objeto de estudo da questão indígena em si para os conceitos utilizados para pensá-la. Pensar o conceito significa questionar os significados e sentidos impregnados na palavra, é questionar os instrumentos do pensamento. Essa forma de questionamento é muito comum no processo de escolarização, que descontextualiza o conceito, destacando-o do seu uso cotidiano, para pensá-lo como um sistema um pouco mais organizado de generalizações. Assim, ao problematizar os conceitos "índio", "selvagem" e "normal" com os alunos, o coordenador atua como um mediador não apenas de novos sentidos e significados, mas de uma maneira específica de pensamento conceitual sistematizado.

Ao fim do episódio, o coordenador propõe uma inversão, um novo sentido para a palavra "selvagem":

CP: A palavra selvagem é de quem vive na selva. A palavra selvagem não necessariamente... É óbvio, né, falava-se que quem vivia na selva era mais violento. Mas se a gente parar pra pensar... 


\section{Z: Selvagem é quem vive na selva, então eles eram selvagens!}

CP: Selvagem é quem vive na selva, a palavra selvagem é que vive na selva.

Z: Então eles eram, né, porque eles viviam na selva.

CP: Mas não necessariamente quer dizer que ele seja mau, entendeu? Claro que, quando eles falavam "selvagem", eles acreditavam que uma pessoa só por viver na selva, era violenta.

Talvez devido à insistência da aluna Z em conceituar os índios como selvagens, o coordenador muda a estratégia e ao invés de apenas indagar 0 que seria o conceito "selvagem", ele dá uma definição diferente daquela utilizada pela aluna. É como se recuasse e fizesse uma concessão, admitindo que os índios eram selvagens, mas que isso significava essencialmente que eles viviam na selva, e que não eram necessariamente violentos. Aliás, essa definição do "selvagem" como habitante das selvas não apareceu pela primeira vez com o coordenador, mas com a aluna $\mathrm{M}$, no início do episódio ("Uma pessoa que vive no mato!"). Dessa maneira, ao trazer um significado mais "dicionarizado" para a palavra "selvagem" - o de que selvagem é que vive na "selva" - tenha tentado dar um caráter menos preconceituoso e mais técnico à palavra, já que a aluna $Z$ insistia em utilizá-la para qualificar os "índios".

$Z$ compreende $\mathrm{O}$ movimento $\mathrm{e}$ imediatamente concorda, sem necessariamente desfazer a sua opinião anterior sobre os indígenas. Nesse sentido, a tentativa do coordenador em ressignificar a palavra "selvagem" foi frustrada, pois no limite, a aluna se apoiou na concessão do coordenador, e reafirmou a sua hipótese de que os povos indígenas eram de alguma maneira "selvagens" (violentos). Além, disso, seja no período colonial, seja nos dias atuais, há povos indígenas que vivem (ou viviam) em concentrações urbanas. Afirmar que os indígenas eram "selvagens" por viverem na selva, embora fosse uma tentativa do coordenador de relativizar uma visão preconceituosa, acaba por afirmar outro estereótipo que recai sobre povos originários, o de que eles não eram capazes de constituir sociedades urbanizadas. 
A formação do pensamento conceitual envolve não apenas a aquisição de palavras (signos) as quais se atribui socialmente um significado, mas a disputa, a ruptura, a recriação e a redefinição de sentidos e significados atribuídos a palavras já utilizadas. Para Vigotski,

\begin{abstract}
O resultado mais importante de todas as investigações nesse campo é a tese solidamente estabelecida segundo a qual os conceitos psicologicamente concebidos evoluem como significados das palavras. A essência do seu desenvolvimento é, em primeiro lugar, a transição de uma estrutura de generalização a outra. Em qualquer idade, um conceito expresso por uma palavra representa uma generalização. Mas os significados das palavras evoluem (VIGOTSKI, 2010, p. 246).
\end{abstract}

Para o autor, portanto, o desenvolvimento psicológico não está restrito a apenas uma fase específica da vida, mas se dá ao longo da trajetória dos sujeitos. Se partirmos do pressuposto de que o pensamento conceitual é socialmente constituído, teremos que admitir que os significados podem se transformar conforme as vivências do sujeito na cultura. No caso da escolarização, que demanda uma forma histórica e culturalmente estabelecida de pensamento sistematizado, poderíamos dizer que os sujeitos que dela participam entram em contato não apenas com novos conceitos, mas também com novos sentidos e significados para palavras já conhecidas a partir das experiências cotidianas. Alunos jovens e adultos - e também professores - da EJA não são sujeitos estagnados em seu desenvolvimento (como aliás o senso comum tem considerado os adultos), mas a partir das relações próprias da escolarização podem entrar em contado com novos atributos que caracterizam determinados objetos, novas generalizações, novas relações entre conceitos. Através dessas relações entram em contato com informações novas para eles, como o fato de que há alunos nas cidades cujos parentes são indígenas, ou que a palavra "selvagem" não se refere necessariamente (ou somente) a um comportamento violento, mas à localização territorial daqueles que habitam selvas. A escolarização seria capaz de propor, portanto, novos sentidos e 
significados de palavras já conhecidas, intervindo em aspectos do desenvolvimento dos sujeitos.

Dentro dessas condições, a sala de aula se torna um importante espaço de negociação (ou não) de significados, como o exemplificado acima com a palavra "selvagem". Em praticamente todo o episódio percebe-se a relação dialógica entre discursos, vindos dos sujeitos em questão, que respondem constantemente um ao outro de maneira polêmica, tornando a palavra uma arena de luta. Na medida em que a escola de alguma maneira possibilita e ao mesmo tempo limita a elaboração conceitual, percebemos como nas interações os sujeitos se posicionam e polemizam uns com os outros, se relacionando através da palavra.

\subsubsection{Processo de (re)criação}

No episódio seguinte, o dia está muito frio e úmido, enquanto os alunos chegam pela manhã. A nossa presença na sala após algumas semanas é mais aceita, recebendo simpáticos cumprimentos e gerando pequenas conversas. $O$ professor, como de costume, chega à sala poucos minutos após os alunos, e a primeira coisa que faz é a chamada. Alguns alunos adolescentes chegam atrasados, e quando o professor inicia a explicação, os alunos se mostram interessados. A sala é apertada e está cheia, e não são utilizados livros. Durante boa parte do tempo, a explicação e o debate ocupam as aulas.

O professor começa a falar e introduz o tema do ciclo do ouro no Brasil durante o período colonial, ocorrido entre os séculos XVII e XVIII. Após longa introdução sobre a atividade da mineração, que essencialmente privilegiou a sua fala, questiona os alunos sobre como os exploradores e bandeirantes encontravam ouro no território da América Portuguesa.

Três alunos são particularmente interessados. Z é uma senhora aposentada e branca, San é um adolescente negro, enquanto Sol é uma mulher trabalhadora. Eles interagem bastante nas aulas em geral, tanto entre si 


\section{quanto com o professor. No episódio seguinte, eles participam e elaboram bastante sobre as perguntas do professor a respeito da mineração.}

\section{Episódio 3}

Professor: Eles andavam pelo interior, e já que estavam andando pelo interior, estavam tentando encontrar também ouro e prata, pedras preciosas, o que viesse. Tudo era lucro pra esses caras. Vocês têm ideia de como é que eles encontravam ouro por aí?

San: Cavando no chão. Tem parede que eles quebram, professor. Eles quebram assim (gesticula), até encontrar ouro.

Prof: Vamos pensar. Você está andando pelo mato. Sei lá, pra um lugar que não tem cidade. É grande, certo? O negócio é enorme (gesticula), o espaço que você está usando. Onde é que você vai começar? Você vai precisar de uma pista, pra você começar a cavar. Você não pode cavar em qualquer lugar. Vai passar a vida inteira cavando e não vai achar nada, não é? Você precisa de alguma pista de que ali pode ter ouro. Qual será que era a pista que os caras encontravam?

Z: Uma pedreira, coisa assim, para eles acharem?

Prof: Então, mas a pedreira ainda não existia. Eles estavam andando em lugar que não tinha ninguém, estava abandonado.

Z: Não tinha pedra, nada?

Prof: Tem lá o ouro, tem lá as pedras. Mas nada vai ficar brilhando lá.

Sol: Ele tá perguntando como é que eles sabiam.

Z: Mas não é assim onde tem pedra, que possa achar pedras preciosas?

Prof: Então, mas todo lugar tem pedra.

Z:Então eram os índios, professor?

Prof: Então, os índios não conheciam o ouro. Nossos índios não usavam o ouro pra nada. Eles não usavam minério nenhum. A gente diz que eles viviam ainda na idade da pedra, vamos dizer assim de uma maneira simples. Então eles não sabiam derreter metal, derreter minério pra fazer metal. Eles não sabiam isso.

Z: Nem sabiam o valor que ele tinha.

Prof: O índio só usava a pedra que ele quebrava e ele polia, sementes, madeira...

Sol: Ossos.

Prof: Ossos. Isso aí. Mas metal, o índio não sabia usar. Então o índio não era pista pro nosso português, pro nosso bandeirante, procurando ouro. A pista em geral eram riachos. Os bandeirantes, qualquer explorador quando anda pelo mato, sempre tenta andar perto de água, pra não morrer de sede, não é? Andavam perto de água. Então esqueçam o rio Pinheiros 
imundo do jeito que ele está. Pensem num rio limpo! Num rio, riacho, sabe riachinho? Não um rio de um quilômetro de largura e dez metros de profundidade, que não dá. Pensem num riachinho daqueles que dá pra gente andar dentro. Com água bem limpa, isso tinha de monte no Brasil daquela época.

Após uma narrativa que introduziu a mineração no período colonial, o professor lança um problema para a turma: "Vocês têm ideia de como é que eles encontravam ouro por aí?". De uma maneira geral a sala parece acompanhar atentamente a discussão que se segue, mas San, Z e Sol são os alunos que expressam mais as suas elaborações. Enquanto os dois primeiros tentam resolver o problema colocado pelo professor (como os portugueses encontravam ouro), Sol tenta compreender a questão em si, às vezes auxiliando os colegas, mediando a pergunta a eles. Após algumas tentativas, o professor tenta sistematizar os sentidos e explicar como teria ocorrido o início da mineração nos séculos XVII e XVIII.

No episódio acima, três conceitos parecem estar sendo discutidos nessa aula:

- "mineração"

- "ouro"

- "índios"

A partir das interações entre interlocutores são elaborados sentidos sobre esses conceitos. A discussão gira em torno do problema apresentado pelo professor, sobre como se daria o trabalho de encontrar ouro na natureza:

Professor: Vocês têm ideia de como é que eles encontravam ouro por aí?

San: Cavando no chão. Tem parede que eles quebram, professor. Eles quebram assim (gesticula), até encontrar ouro. 
San é um adolescente frequentemente repreendido pelos colegas mais velhos, por chegar atrasado e se distrair com os amigos durante as aulas. No entanto, é um dos alunos mais participativos, alternando momentos de interação com o professor e desinteresse pela aula. Após a explicação do professor, é o primeiro a falar, demonstrando certa familiaridade com o tema. Interessante perceber que em sua resposta, ele parece remeter mais à mineração praticada em Vila Rica (Ouro Preto) e outras cidades da capitania de Minas Gerais no século XVIII (“Tem parede que eles quebram, professor") que à mineração feita em riachos ao longo do século XVII, e que era efetivamente o tema da presente aula. Sendo mais jovem que a maioria dos alunos da sala, talvez tenha tido contato com outras aulas de História recentemente e elementos da discussão sobre a mineração no século XVIII em Minas tenham Ihe ocorrido.

Um pouco adiante no diálogo, o professor percebe que os alunos talvez tenham dificuldade em perceber como o ouro era encontrado antes do auge da mineração em Minas, e muda de estratégia. Ao invés de perguntar como os portugueses encontravam ouro na natureza, passa a perguntar sobre uma "pista" específica:

Professor: Qual será que era a pista que os caras encontravam?

Z: Uma pedreira, coisa assim para eles acharem?

Prof: Então, mas a pedreira ainda não existia. Eles estavam andando em lugar que não tinha ninguém, estava abandonado.

Z: Não tinha pedra, nada?

Prof: Tem lá o ouro, tem lá as pedras. Mas nada vai ficar brilhando lá.

Sol: Ele tá perguntando como é que eles sabiam.

Nos turnos acima é possível perceber que os alunos não simplesmente respondem de maneira passiva o que Ihes é perguntado, mas resignificam o 
objeto de estudo (mineração) em suas falas, lançando novas perguntas ("Uma pedreira, uma coisa assim para eles acharem?") ou interpretando as perguntas do professor ("Ele tá perguntando como é que eles sabiam"). A participação desses alunos (San, Z e Sol) não é reduzida à mera compreensão dos conceitos apresentados pelo professor, mas constitui uma interlocução ativa e dinâmica. Para Vóvio,

\begin{abstract}
A palavra que se dirige a alguém comporta duas facetas: a do locutor, que a significa ao dizê-la e a do interlocutor que, ao recebê-la, a resignifica. Mais que o simples ouvir e compreender, 0 sujeito que recebe 0 discurso participa ativamente do processo de comunicação, concordando, discordando, questionando, respondendo, assumindo então o papel de locutor, mesmo que esteja presente apenas virtualmente, como no caso dos textos escritos (VÓVIO, 1999, p. 15).
\end{abstract}

Assim, Vóvio concorda com Bakhtin (1992) sobre o papel ativo do interlocutor ao compreender e interagir com um determinado discurso. Embora o professor seja, pelo seu papel em sala de aula aquele que mais fala, e que traz mais significados dos conceitos abordados, isso não impede que o diálogo entre ele e os alunos tenha uma certa abertura para a elaboração de sentidos, para a criação de novas interpretações. Cada turno evidencia uma dinâmica de interações que devem a sua existência a falas anteriores e que abrem espaço para novas elaborações. Enquanto o professor argumenta que não era possível encontrar ouro apenas em meio às rochas na natureza, $Z$ parece presumir que uma "pedreira" seria um espaço natural, onde se encontrariam rochas e pedras preciosas, e não um lugar de exploração de minérios pelo trabalho humano (atividade econômica). O professor parece não compreender - ou ignora - que há um mal entendido quanto ao significado da palavra "pedreira" entre ele e a aluna, e afirma que não seria possível encontrar ouro em "pedreiras" porque elas ainda não existiam. Z então muda sua estratégia de argumentação: 
Prof: Então, mas todo lugar tem pedra.

Z: Então eram os índios, professor?

Até então, o diálogo consistia na pergunta do professor sobre como os colonizadores encontravam ouro, e na argumentação de $Z$ de que eles poderiam procurar "pedreiras". Como o professor aparentemente não corroborou sua argumentação, alegando que não era possível encontrar metais preciosos apenas em meio a lugares com muitas rochas, a aluna recorre a outra hipótese: os índios poderiam auxiliar os portugueses na busca pelo ouro. O professor, então, argumenta que os indígenas não poderiam ajudar os portugueses na busca pelo ouro porque eles viviam na "idade da pedra", e conclui o episódio com uma explicação que responde à sua pergunta inicial sobre as "pistas" para encontrar ouro:

Prof: Mas metal, o índio não sabia usar. Então o índio não era pista pro nosso português, pro nosso bandeirante, procurando ouro. A pista em geral eram riachos.

Durante todo o episódio, o diálogo esteve sob a condução do professor, que após uma explicação que privilegiou a sua fala, abriu a aula para a participação dos alunos, a partir de um tema específico, a mineração. Se, por um lado, a pergunta "Vocês têm ideia de como eles encontravam ouro por aí?" delimita de alguma maneira as elaborações dos alunos em torno dessa enunciação, por outro demanda que eles se esforcem por compreender minimamente o tema "mineração", como parte de um assunto maior, a "colonização portuguesa", e tentem participar ativamente, como interlocutores do professor, da aula de História.

Outro aspecto decorrente da dinâmica comunicativa e que reforça a noção de que se trata de um processo complexo de interação é o de que um enunciado (unidade da comunicação 
verbal) não se encontra isolado. Ele deve a sua existência a enunciados anteriores que, de alguma forma, se relacionam e o conformam. Seu conteúdo está permeado por enunciados já recebidos e significados e que dão origem a outros (VÓVIO, 1999, p. 15).

A partir de Bakhtin (1992), a autora postula que a dimensão dialógica deve ser levada em conta na análise das interações. No caso em questão, elas são circunscritas a um tema, mas não absolutamente controláveis pelo professor, há uma intensa elaboração de conceitos como "mineração", "ouro", e, mais uma vez, "índios". Apesar de o debate ser ainda bastante inicial e incipiente, carecendo de atributos mais generalizáveis e sistematizados, é importante notar que o debate a respeito desses conceitos dificilmente seria realizado no cotidiano dos alunos, fora de uma aula de História. Nas interações percebe-se que a mediação do professor introduz um conceito e possibilita que os alunos reflitam, questionem, discordem e duvidem das colocações dele. A elaboração de sentidos para esses conceitos ocorre em sala de aula, bem distante de seus referentes, abrindo espaço para a reflexão sobre a mineração para alunos que não trabalham nisso e não vivem em regiões cuja principal atividade econômica seja essa. A escola possibilitaria, portanto, a formação do pensamento sobre os conceitos de maneira descontextualizada, independente da realidade a qual se referem. Não é preciso estar em uma área de mineração para se refletir sobre ela, por exemplo.

Para Tulviste (1991), uma das características atribuídas por Vigotski ao pensamento por conceitos científicos ou sistematizados seria a constituição de uma operação mental própria da escolarização e da sociedade industrial contemporânea, que consiste na reflexão sobre o conceito em si, separado do seu referente. A partir das interações entre sujeitos no episódio acima, percebe-se o esforço, ainda que inicial, de uma operação mental complexa, de reflexão de um conjunto de objetos que na verdade estão ausentes da sala, mas presentes psicologicamente. $O$ professor introduz o tema da mineração, que concretamente não está na sala, mas se torna presente no discurso pela palavra, e passa a ser reconstruído psicologicamente: 
Professor: Vocês têm ideia de como é que eles encontravam ouro por aí?

San: Cavando no chão. Tem parede que eles quebram, professor. Eles quebram assim (gesticula), até encontrar ouro.

Em sua fala, San traz para o professor e para os colegas atributos do conceito "mineração" e "ouro": a atividade consiste em quebrar paredes. O aluno chega inclusive a simular com os braços o movimento envolvido no trabalho, dá a entender que daquela maneira se arrancam metais preciosos das rochas. Mais adiante, a elaboração entre os sujeitos em sala de aula sobre os conceitos discutidos segue:

Prof: Qual será que era a pista que os caras encontravam?

Z: Uma pedreira, coisa assim para eles acharem?

Em sua resposta à pergunta do professor, Z elabora uma possível resolução (encontrar ouro em uma pedreira) do problema (os portugueses necessitavam de uma pista para encontrar metais preciosos) que, independente de estar correta do ponto de vista histórico, representa uma elaboração mental a respeito de um objeto ausente em sala de aula, uma reflexão sobre os conceitos ("mineração", "ouro"). A constituição do pensamento conceitual nesse caso não se deu a partir da inserção do sujeito na atividade econômica propriamente dita da mineração, mas a partir de um contexto escolar que possibilitou a reflexão dos sentidos e significados do conceito sem a necessidade da presença concreta do referente no contexto da discussão.

Além disso, a participação dos alunos não se restringe a encontrar as respostas às perguntas do professor, mas em participar ativamente da 
elaboração de sentidos sobre os conceitos discutidos na aula de História como se pode perceber nos seguintes turnos:

Prof: Então, os índios não conheciam o ouro. Nossos índios não usavam o ouro pra nada. Eles não usavam minério nenhum. A gente diz que eles viviam ainda na idade da pedra, vamos dizer assim de uma maneira simples. Então eles não sabiam derreter metal, derreter minério pra fazer metal. Eles não sabiam isso.

Z: Nem sabiam o valor que ele tinha.

Prof: O índio só usava a pedra que ele quebrava e ele polia, sementes, madeira...

Sol: Ossos.

Prof: Ossos. Isso aí. Mas metal, o índio não sabia usar. Então o índio não era pista pro nosso português, pro nosso bandeirante, procurando ouro. A pista em geral eram riachos.

Nos turnos acima, Z e Sol trazem para o diálogo diferentes sentidos do conceito "índio" (o índio não sabia o valor do ouro, o índio fazia objetos com ossos), relacionando-o ao conceito "mineração" e "ouro" (a mineração do ouro era ignorada pelo índio, o ouro era desconhecido pelos índios), a partir de uma enunciação do professor sobre a colonização. Não apenas a escolarização possibilita a construção de sentidos e significados de objetos ausentes da sala e descontextualizados das práticas cotidianas dos alunos, mas ela também possibilita a constituição de esquemas teóricos e de relações entre os conceitos, no caso, "mineração", "ouro" e "índios" (Oliveira, 2009). Ao longo do episódio foram construídos, nas interações entre os sujeitos, diversas relações entre os principais conceitos utilizados, que embora de maneira inicial, apontam já para a constituição em aulas de História, de pensamento conceitual, tais como: a mineração começou como uma atividade extrativista de busca do ouro por parte dos europeus; o ouro podia ser encontrado em riachos; os índios não dominavam a metalurgia e estavam na "idade da pedra", construindo materiais com outras matérias primas.

Segundo Góes e Cruz (2006), Vigotski teria concluído ao fim de "A Construção do Pensamento e da Linguagem" que o sentido subordina 0 
significado. Enquanto esse último constituiria generalizações mais sistematizadas dos conceitos utilizadas socialmente, os sentidos levariam em consideração, sobretudo, as vivências dos sujeitos e o caráter dinâmico da palavra. Para as autoras,

Se o conceito se constrói numa indispensável relação com a significação da palavra, então o conhecimento sobre o mundo não pode ser reduzido apenas à zona mais estável do campo dos sentidos - aquela do significado. Se a generalização é o ato fundamental que constitui a palavra e o conceito, ela não deve ser concebida fora do movimento de dispersão e de criação de múltiplas significações. Se a categorização da realidade é construída sobre a base de experiências vivenciais concretas, ela não deixa de ser atravessada pelo caráter dinâmico da significação, que tem lugar no contexto da cultura, em suas condições estáveis e instáveis, e que se refletem no acontecimento da interação verbal, em suas condições específicas de ocorrência e nas vicissitudes das motivações e características de personalidade dos sujeitos (GÓES; CRUZ, 2006, p. 42).

Assim, no episódio em questão, a constituição de pensamento conceitual em sala de aula se tornou possível porque os sujeitos se encontravam em um contexto privilegiado para a elaboração de sentidos de determinados conceitos. Ao longo do episódio, podemos perceber que os principais conceitos receberam diferentes sentidos por parte dos sujeitos (alunos e professor):

- "Mineração": podia ser feita quebrando paredes; era realizada procurando ouro em riachos; "pedreiras" poderiam ser lugares com metais preciosos; os índios poderiam ajudar a encontrar ouro na mineração;

- "Ouro": estava oculto em paredes e rochas; poderia ser encontrado em pedreiras; os índios talvez soubessem onde encontrá-lo; era encontrado em riachos; 
- "Índios": possivelmente sabiam onde estava o ouro na natureza; estavam na idade da pedra, utilizavam pedras, madeiras, sementes e ossos como matérias-primas de seu trabalho.

Todos esses elementos, construídos na interação entre os sujeitos no episódio acima, independente de estarem corretos do ponto de vista historiográfico, constituem (re)criações de sentidos na aula de História. Para Góes,

Considerando-se o contexto pedagógico, o professor busca eleger certos sentidos, canalizando aí o esforço de elaboração, e transformar o funcionamento conceitual do aluno, na direção do conhecimento sistematizado. Também os pares são participantes das elaborações conceituais do aluno. Dependendo da linha de ação pedagógica, os efeitos podem ou não corresponder aos conhecimentos pretendidos, podem gerar êxitos ou fracassos escolares. Entretanto, em qualquer dos casos, é na dinâmica dos processos interpessoais, nas trocas dialógicas com outras pessoas em torno de objetos, nas instâncias de produção e compreensão da palavra, que o aluno desenvolve os significados desta (GÓES, 1997, p. 21).

A mediação pedagógica do professor e as práticas pedagógicas não necessariamente garantiriam o êxito na constituição de determinados conceitos científicos com os alunos, mas possibilitariam a construção deles a partir das interações próprias do espaço escolar. O que chama a atenção no episódio acima não é se o professor foi exitoso em sua tentativa de ensinar determinados conceitos científicos com os alunos ("mineração", "ouro", "índios"), mas sim o fato de que pela interação entre os participantes da aula foram atribuídos diversos sentidos aos conceitos discutidos. A formação do pensamento conceitual se dá não de maneira determinada pela escola, nem tampouco ao acaso, mas na complexa interação entre os sujeitos e suas elaborações, mediados pela linguagem e pelas possibilidades e limites das práticas escolares. 
Essas interações também se dão na medida em que os alunos apresentam em suas falas elementos de "conceitos cotidianos", constituídos em suas vivências, e trazidas à sala de aula, e os confrontam com a fala do professor, que se coloca no lugar de quem traz uma fala mais científica, sistematizada. Ao comentar os escritos de Vigotski, Góes (1997) afirma que

[...] acrescentam-se discussões, mais orientadas para o âmbito educacional, sobre os processos de constituição de conceitos cotidianos e científicos. Esses dois processos diferem entre si, mas mantém uma relação de alimentação recíproca - os conceitos cotidianos fundamentam, dão base vivencial aos científicos/escolares, e estes podem trazer sistematização e elevação de níveis de generalidade aos cotidianos. É também importante salientar que a palavra tem papel fundamental em ambos esses processos, porém com inserção diferente em cada caso: no conceito cotidiano, ela vai mediar a vivência com o objeto; no científico, vai marcar a relação com outros conceitos, numa rede de palavras já significadas (GÓES, 1997, p. 21).

Diante do problema apresentado pelo professor ("Como é que eles encontravam ouro por aí?"), a aluna Z inicia sua participação propondo que os portugueses deviam procurar ouro em "pedreiras". Depois, a partir da interação com o professor, muda sua estratégia e sugere que os indígenas deviam ajudar a encontrar o ouro. Ao fim, professor explica que os indígenas na América portuguesa não dominavam a metalurgia e que os portugueses iniciavam a procura a metais preciosos em riachos. Percebe-se, assim, como ao longo da interação entre sujeitos, palavras como "mineração", "ouro", "índios" são utilizadas pela aluna $Z$ em sua fala com elementos de conceitos cotidianos (pois essencialmente trazidos a partir das elaborações e vivências da aluna), e aos poucos, sistematizadas na interação com o professor, que traz elementos de conceitos científicos, como a organização entre conceitos (os índios não dominavam a metalurgia, o ouro era encontrado pelos portugueses em riachos). Ainda que o professor de certa maneira intervenha no sentido de uma certa estabilização dos sentidos dos conceitos debatidos, é improvável que ele tenha tido controle sobre o processo de elaboração dos alunos. Mesmo assim, 
o debate em sala de aula possibilitou a relação entre dois processos diferentes de elaboração (pensamento por conceitos cotidianos e científicos).

Assim, ao observar as elaborações dos alunos sobre o tema da mineração no período colonial, estamos diante de um processo dialético de formação de pensamento conceitual, mediado socialmente pela palavra, no pensamento do sujeito. Para Vigotski,

[...] o significado da palavra é, ao mesmo tempo, um fenômeno de discurso e intelectual, mas isto não significa a sua filiação puramente externa a dois diferentes campos da vida psíquica. O significado da palavra só é um fenômeno de pensamento na medida em que o pensamento está relacionado à palavra e nela materializado, e vice-versa: é um fenômeno, de discurso apenas na medida em que o discurso está vinculado ao pensamento e focalizado por sua luz. É um fenômeno do pensamento discursivo ou da palavra consciente, é a unidade da palavra com o pensamento (VIGOTSKI, 2010, p. 398).

Discutir sobre a mineração é pensar em sala de aula sobre a mineração. Pensar sobre como os portugueses encontravam ouro só é possível utilizandose das palavras relacionadas ao tema. Os sujeitos pensam, perguntam, questionam, concordam, discordam uns dos outros. Essa elaboração conceitual é possibilitada pela escolarização, orientada por significados aceitos socialmente pelo conhecimento histórico sistematizado, particularmente mediado pelo professor (mas não só). A formação do pensamento conceitual se mostra, assim, um processo criativo, interativo e dialógico.

\subsection{4. "Eu pensava que era verdade!"}

O tema da aula no episódio a seguir - a Independência do Brasil - é especialmente polêmico na historiografia e muito presente no imaginário da população, pois constitui parte da identidade nacional do país. Talvez por isso 
tenha provocado intensa participação dos alunos na aula, com perguntas, comentários e discussões.

Os alunos chegaram à sala neste dia específico comentando a respeito da festa junina que havia ocorrido dias antes. O professor chega logo em seguida e começa a aula perguntando o que eles estavam estudando nas últimas semanas, tentando fazer com que os alunos se lembrem dos conceitos discutidos nas aulas anteriores. Os alunos hesitam e não respondem a essa pergunta com uma palavra que defina algum período histórico ("Brasil Colonial") ou um tema ("escravidão", "ciclo da cana de açúcar"), mas com palavras que remetem às suas memórias das aulas passadas: "exploração", "portugueses".

O professor estava há algumas semanas discutindo a colonização da América Portuguesa, os ciclos econômicos do período e o tipo de mão de obra utilizada. Nesta aula, especificamente, planejou introduzir o processo de independência do Brasil. Para isso, trouxe algumas cópias de um exercício de um livro didático de História. Nele, estava uma reprodução (que ficou um pouco prejudicada, pelo tamanho pequeno e por estar em preto e branco) da tela "Independência ou Morte" de Pedro Américo (1843-1905), concluída em 1888. Abaixo da reprodução da tela, na mesma folha, havia algumas questões sobre a obra a serem respondidas pelos alunos em seus cadernos.

Ao longo da aula, o professor foi pedindo que alguns alunos lessem os parágrafos do texto, para em seguida comentar e discutir com os alunos. Ao fim das leituras, conduziu com os alunos uma leitura da reprodução da obra de Pedro Américo. Ele conscientemente faz uma leitura da imagem, a partir dos seus elementos: a paisagem, as moradias, os personagens históricos, a forma como todos eles estão dispostos na imagem. Constrói essa discussão com um jogo de perguntas e respostas com os alunos. Em sua participação, a maioria dos alunos parece interessada, acompanhando atentamente as perguntas sobre a imagem. Eles parecem estar relativamente à vontade para responder, perguntar, comentar. Evidentemente, há os estudantes que sempre falam, os que participam eventualmente e aqueles que não se expõem tanto. $O$ 
professor, Z (mulher idosa, branca), San (adolescente negro), F (mulher trabalhadora, branca), $\mathrm{M}$ (mulher trabalhadora, negra) e $\mathrm{R}$ (mulher trabalhadora, branca) são os sujeitos que mais participam deste diálogo, mas de uma maneira geral a sala se envolve bastante nessa aula.

O episódio a seguir se deu em meio às discussões que o professor propôs para a leitura da reprodução da pintura "Independência ou Morte":

\section{Episódio 4}

Prof: Como o texto diz, o D. Pedro não era nenhum super-herói, né? De história em quadrinho. Super-homem, que faz as coisas sozinho, resolve todas as paradas. Ele era um homem comum, como nós, então era impossível que ele sozinho fizesse tudo. Então esse quadro, esse quadro aqui, ele não representa uma cena verdadeira. Essa cena aqui não aconteceu. Isso aqui não é como se o pintor tivesse voltado lá no passado, tirado uma fotografia de uma coisa que aconteceu e botou no quadro. Essa cena não se passou.

San: Não aconteceu? Eu sabia!

Prof: Isso aqui é imaginação do pintor! Ele imaginou essa cena pra destacar a pessoa do $D$. Pedro na independência.

Alunos: Nossa!

Prof: Me encomendaram um quadro pra eu falar que o D. Pedro foi "o cara" da independência. Como é que eu...

San: Isso aqui é uma simulação, né?

Prof: Isso!! Mas nem uma simulação assim, do tipo, San, de uma coisa que aconteceu. Isso aqui não aconteceu! É inventado pelo pintor.

R: Nossa, pensava que aconteceu!

Prof: Inclusive esse quadro é meio cópia de um quadro francês em que no lugar do D. Pedro tá o Napoleão Bonaparte.

R: Pra que fazer isso? Eu pensava que tinha sido verdade!

Prof: Os estudiosos acharam um quadro no qual o pintor brasileiro se baseou pra fazer esse aqui. Napoleão era um imperador francês muito famoso, dessa época também.

M: Ah, mas a gente olha e pensa que é verdade!

Prof: Pois é, a gente olha e pensa que é verdade!

$R$ : Mas eu pensei que era!

Prof: $O$ que é que tem de verdade aqui? 
San: Você quer que eu fale o que tem de verdade? O lugar que existe.

Prof: O lugar! O lugar existe.

M: A casa! A casinha.

Prof: Provavelmente tinha uma casinha. Eu não sei se desse jeito, mas tinha lá uma casinha.

M: Riacho!

Prof: Tinha lá o riacho! E...? E...? D. Pedro passou por esse lugar. É verdade que ele passou por esse lugar. Aconteceu alguma coisa por esse lugar. Que a gente vai comentar depois. Mas não desse jeito. Só pra começo de conversa, D. Pedro não tava montado a cavalo. Nessa época, tava em cima de uma mula.

$R:$ Ai, professor! (risos) Que é isso?!?

Prof: Nessa época se andava em lombo de mula aqui no Brasil.

San: Mula é o quê? Mula é aquele bicho sem cabeça?

Prof: Não, essa é a mula sem cabeça. Põe cabeça na mula.

San: Mas existe mula sem cabeça?

Z: Por que, não tinha cavalo?

Prof: Tinha, mas pras longas viagens, a mula é mais resistente, o pessoal viajava de mula. Eu vou dar uma pesquisa pra vocês saberem exatamente o que é um jumento e uma mula. Volta aqui! Vocês acham que ia ficar legal se ele tivesse pintado o D. Pedro em cima de uma mula?

San: la!

Prof: la ser impactante, assim?

Sala: Não!

Prof: Não ia ser impactante, né? Então ele botou D. Pedro em cima de um cavalo, pra ficar mais...

San: ((Bocejo))

M: Ele devia colocar a verdade!

Prof: Esses caras todos que tão em volta... Essa cena, como eu disse, não aconteceu. Mas essa gente... Passou uma tropa aí, com o D. Pedro. Ele tava indo visitar a amante dele em Santos. E ele tava em lombo de mula. Tava todo mundo montado em lombo de mula. Ninguém tava a cavalo. Então só pra vocês saberem que a cena foi inventada pelo pintor. Não tomem isso... Por isso que eu botei ela aqui, pra gente conversar sobre isso. Não tomem isso como uma cena real.

R: Nossa, eu pensava que era assim. Quanto tempo!! Ah, eu pensava que o Brasil tinha sido independente por causa do grito dele lá. E tornou-se independente. Eu pensava que era verdade! 
Prof: Mas eu vou te dizer uma coisa, menina.

R: Quando ele gritou: "independência ou morte".

Prof: Aí resolveu tudo!

R: Aí resolveu tudo, o Brasil tornou-se independente. Eu pensava que era!

San: Todos nós.

F: Independente foi quando ele começou a vender as coisas, né?

Prof: Isso! Nós vamos chegar aí, F! Nós vamos chegar aí. Só pra aproveitar a sua observação, quando eu fiz o primário, minha professora me ensinou assim.

Alunos: Foi, desse jeito!

Prof: Mostrou o quadro e falou: essa aqui é a independência do Brasil. D. Pedro tava em cima do cavalo, berrou independência ou morte, e resolveu. Agora pensem vocês com vocês mesmos. Um cara sobe no cavalo, dá um berro desse. E daí? Escutaram lá em Portugal o grito dele? Pois é. Eu fico gritando o dia inteiro dentro da minha casa: "eu sou o presidente da República, eu sou o presidente da República". Eu viro o presidente da República?

Alunos: Não!

Prof: Não, nem ouvem. Aliás, tão pensando em me internar, pensando que eu sou louco, inclusive.

Alunos: (Risos)

Prof: Então, não parece que o pintor tava lá e pintou? Não, isso aqui foi pintado... Vinte e dois... Foi pintado na década de sessenta... Isso aqui foi pintado quarenta anos depois. Como eu disse, D. Pedro já tinha morrido. O pintor nem conhecia o riacho do Ipiranga. Ele tava no estúdio dele e pintou.

\section{Z: Ele criou?}

Prof: É, ele criou! Falaram: o lugar é mais ou menos assim. Aí ele criou.

Alunos: Ele nem conhecia?

Prof: Não! Entendeu? Tudo bem? Então isso aqui não é uma cena real, por favor! Não é uma representação da realidade.

San: Mas real é o que aconteceu. Ou não aconteceu?

Prof: Então! D. Pedro passou por aqui, ficou nervoso aqui. Ele falou a frase, segundo tudo indica aqui...

San: Foi mais razoável.

Prof: Foi mais realista. Isso aqui tá muita fantasia, né? Parece Jurassic Park, né? Ali no Museu do Ipiranga. Tudo bem, então? Isso era pra chamar a atenção. Nós não vamos falar na aula de hoje o que de fato, enfim, aconteceu nessa situação aqui. Provavelmente nós falaremos na 
aula de amanhã. Mas eu só coloquei aqui pra gente pensar que a independência não foi fácil. Um cara berra e tá tudo feito. Não foi bem assim!

Z: Teve luta, né? Teve morte.

Prof: É, foi mais complicadinho. A gente vai ver resumido, não dá pra ver com todos os detalhes. Mas foi mais complicadinho.

No episódio acima, o professor medeia uma leitura da reprodução de "Independência ou Morte" de Pedro Américo, cujo objetivo é a desconstrução do conteúdo da pintura como "verdade histórica", o que aparentemente causa bastante espanto nos alunos. Grande parte deles expressa bastante surpresa ao descobrir pela fala do professor que há uma grande diferença entre o processo de Independência do Brasil como se deu e a maneira como tradicionalmente é narrada na pintura de Pedro Américo. Apenas uma aluna, em um turno, demonstra outra leitura do processo de independência, como se verá a seguir.

A imagem, bastante prejudicada pela em cópia preto e branco, traz um determinado discurso sobre a Independência do Brasil, aparentemente conhecido pelos alunos. O professor, pela sua leitura da imagem e explicação com os alunos, tenta trazer outra versão da independência, que não fica clara nessa aula (ele afirma que vai explicar mais detalhadamente na aula seguinte), mas é perceptível ao longo de sua fala. Nessa aula em especial, ele parece estar mais preocupado em explicar o contexto histórico de produção da pintura de Pedro Américo. Nos turnos do episódio, poderíamos dizer que há pelo menos três discursos em disputa na sala de aula:

- Um primeiro discurso que dialoga com a pintura "Independência ou Morte", e refletido pela maioria dos alunos, que afirma que o sujeito da Independência do Brasil foi D. Pedro I; auxiliado pelos militares, heroicamente deu um "grito da independência" contra Portugal, às margens do Rio Ipiranga em São Paulo ("Nossa, eu pensava que era assim. Quanto tempo! Ah, eu pensava que o Brasil tinha sido 
independente por causa do grito dele lá. E tornou-se independente. Eu pensava que era verdade!");

- Um segundo discurso, trazido em apenas um único turno pela aluna $F$, que expressa de maneira simples que a Independência do Brasil está atrelada a um processo de mudança econômica, orientado para o comércio do Brasil com outras nações, sem o monopólio do comércio por parte da metrópole portuguesa ("Independente foi quando ele começou a vender as coisas");

- Um terceiro discurso, trazido pelo professor, que traz o contexto de produção da pintura "Independência ou Morte", evidenciando seu caráter de criação de uma versão histórica dos acontecimentos comprometida com determinados valores e interesses do fim do Segundo Reinado, como a valorização da monarquia na figura de D. Pedro I como herói nacional ("Isso aqui é imaginação do pintor! Ele imaginou essa cena pra destacar a pessoa do D. Pedro na independência").

Cada um desses discursos é produzido socialmente e se materializa na palavra, no caso, em sala de aula. A interação entre sujeitos constitui uma das formas de relação dialógica entre discursos: "O interlocutor só existe enquanto discurso. Há, pois, um embate de dois discursos: o do locutor e o do interlocutor, o que significa que o dialogismo se dá sempre entre discursos." (FIORIN, 2006, p. 166).

Os sujeitos não se relacionam diretamente com o mundo, mas por meio de discursos que medeiam a realidade. Esses discursos se direcionam a outros, em uma relação dialógica que constitui o funcionamento da linguagem. Parte dos alunos no episódio acima parece assumir, pelo menos no início, um determinado discurso sobre a independência, em consonância com a pintura de Pedro Américo, que foi constituído histórica e socialmente desde o fim do século XIX. O professor, por outro lado, se filia a um discurso de desconstrução dos elementos da imagem e sua versão histórica, que corresponde a uma 
determinada metodologia muito utilizada por professores de analisar criticamente as pinturas históricas. Uma aluna, F, em um único turno, traz um discurso com conteúdo de explicação econômica para a independência. No embate entre essas três visões do passado, trazidos na relação concreta entre esses sujeitos em sala de aula, pode-se perceber a relação dialógica entre discursos diferentes, dentro da dinâmica da aula de História.

Nas interações em um contexto escolar, como as apresentadas no episódio acima, percebe-se um conflito entre o discurso mais inclinado para a versão tradicional da independência de Pedro Américo, e outro no sentido oposto, de contextualização da produção social da pintura. Para alguns autores da Didática da História, todo conhecimento histórico, inclusive o apreendido fora da educação formal é significativo, pois constitui uma experiência que torna o passado presente, mediando a relação dos sujeitos com a sociedade à qual pertencem (KOSELLECK, 2006).

Em vários turnos do episódio, percebe-se uma identificação dos alunos com a imagem de "Independência ou Morte", que sintetiza uma das versões mais tradicionais do processo de independência do Brasil, presente no Museu Paulista, mas também em livros didáticos e em meios de comunicação de massa. Essa identificação de grande parte dos alunos com essa interpretação tradicional da História pode ser sintetizada no comentário da aluna $\mathrm{M}$ ao olhar a imagem:

M: Ah, mas a gente olha e pensa que é verdade!

Nesse sentido, a consciência histórica trazida pelos alunos na aula, e percebida nesse episódio, se aproxima daquela simbolizada pela pintura "Independência ou Morte", e constitui a experiência histórica (KOSELLECK, 2006) desses sujeitos com o passado. No entanto, quando o professor coloca em dúvida essa versão tradicional da independência do Brasil, o adolescente 
San, ao contrário dos colegas mais velhos, parece ser o menos contrariado, concordando rapidamente com o professor a repeito da duvidosa veracidade da cena do quadro. Em pelo menos dois turnos, podemos perceber o seu posicionamento:

\section{S: Não aconteceu? Eu sabia! \\ (...) \\ S: Isso aqui é uma simulação, né?}

A partir da intervenção pedagógica do professor, que questiona a versão da Independência do Brasil de Pedro Américo, San passa a relativizar o conteúdo de "verdade histórica" do quadro. Enquanto os colegas mais velhos demonstram em suas falas muita surpresa com a explicação do professor de que o conteúdo da pintura não corresponde aos fatos históricos, San é um dos primeiros a perceber que a imagem, por mais importante que ela seja, não necessariamente retrata os acontecimentos históricos tal como aconteceram. Os alunos da sala não compartilham, portanto, da mesma experiência com a História (KOSELLECK, 2006), havendo nesse caso, inclusive uma diferença geracional (ATTIAS - DONFUT, 1988). Isso se explica pelo fato de que cada geração, pela sua localização social, faz uma experiência particular com a sociedade e seu passado (MANNHEIM, 1993). A maioria dos alunos adultos parece ter uma consciência histórica mais próxima da versão tradicional da independência, enquanto o adolescente parece dialogar mais com a dinâmica de leitura dos elementos da imagem, proposta pelo professor.

Uma aluna específica, $F$, vai além. Em uma fala rápida de apenas um turno, traz elementos de um conhecimento histórico relativamente elaborado para a aula: 
Para $F$, a independência não está narrada no discurso da pintura de Pedro Américo, que tem como sujeito D. Pedro I, como representante de uma História baseada nos grandes heróis do passado. A aluna foi além da explicação do professor, que estava preocupado nessa aula apenas com a contextualização da produção da pintura "Independência ou Morte". F traz elementos de uma análise econômica para o tema da aula: a independência do Brasil implicava que o país poderia realizar o comércio exterior de forma autônoma, sem o monopólio econômico da metrópole portuguesa ("começou a vender as coisas"). Não apenas $F$ trouxe outros elementos, mais elaborados para a aula, como foi além do que o professor estava explicando naquele momento.

Aparentemente, o professor dedicou essa aula para fazer a leitura dos elementos da obra "Independência ou Morte" e explicar o seu contexto de produção histórica, para, na aula seguinte, de fato, debater o processo de Independência do Brasil. Nesse sentido, a problematização de uma imagem tradicionalmente utilizada para ilustrar a Independência do Brasil, foi uma introdução em uma sequência didática que pretendia ampliar o repertório dos alunos para além da pintura de Pedro Américo. Assim, nesse caso, o professor parecia estar comprometido em introduzir elementos um pouco mais sistematizados e científicos na reflexão histórica, explicando que a imagem não correspondia a uma verdade histórica, e que ela própria foi produzida a partir de um contexto. Em que pese que o conhecimento histórico escolar não seja uma mera reprodução do conhecimento acadêmico, e que o saber dos alunos sobre o passado seja bastante significativo na constituição de suas identidades sociais, a escolarização não poderia se furtar de oferecer uma experiência histórica mais sistematizada, elaborada a partir de metodologias científicas, propiciando uma relação o mais abrangente possível dos alunos com as várias interpretações da História. Sendo o passado histórico alvo de reflexões com ou sem a escolarização, o ensino de História segue sendo necessário para dar a sua contribuição e qualificar essa reflexão dos sujeitos a partir de noções da 
Histórica como campo do conhecimento sistematizado (BARCA, 2001; BERGMAN, 1985; LEE, 2011).

No episódio acima, o esforço do professor em trazer elementos da história como campo do conhecimento científico parece consistir não em ensinar as interpretações mais atuais sobre o processo de independência do Brasil, mas em explicar aos alunos que a imagem na reprodução da pintura possui ela mesma um contexto de produção sócio-histórico. Parte dos alunos parece partir do pressuposto de que o conteúdo presente em uma pintura histórica tradicional corresponde, de alguma maneira, à verdade dos fatos históricos. Ao longo do diálogo, o professor coloca em dúvida a veracidade do quadro ou tenta explicar como a pintura foi feita, como exemplificado a seguir:

Prof: Me encomendaram um quadro pra eu falar que o D. Pedro foi "o cara" da independência. Como é que eu...

(...)

Prof: Inclusive esse quadro é meio cópia de um quadro francês em que no lugar do $D$. Pedro tá o Napoleão Bonaparte.

(...)

Prof: Então, não parece que o pintor tava lá e pintou? Não isso aqui foi pintado... Vinte e dois... Foi pintado na década de sessenta... Isso aqui foi pintado quarenta anos depois. Como eu disse, D. Pedro já tinha morrido. O pintor nem conhecia o riacho do Ipiranga. Ele tava no estúdio dele e pintou.

No entanto, por mais que o professor tente introduzir elementos do conhecimento histórico sistematizado, como a contextualização da produção sócio-histórica de uma pintura, não se pode afirmar que ele traz para as aulas um conhecimento científico puro. Em sua fala estão presentes diversos elementos que poderiam ser considerados "não científicos", como citações da cultura de massa ("Super Homem", "Jurassic Park"), anacronismos ("Me encomendaram um quadro pra eu falar que o D. Pedro foi "o cara" da independência.", "Eu fico gritando o dia inteiro dentro da minha casa: 'eu sou o 
presidente da República, eu sou o presidente da República'. Eu viro o presidente da República?"), falas que produzem riso nos alunos ("Não, nem ouvem. Aliás, tão pensando em me internar, pensando que eu sou louco, inclusive"). Para Lautier (2011), os professores de História acabam constituindo um conjunto de saberes que não são nem científicos, nem "profanos", que surgem a partir das condições de ensino e das necessidades pedagógicas, essencialmente diferentes das condições e objetivos da pesquisa acadêmica. O professor, no episódio, faz concessões e incorpora elementos não científicos, a partir do contexto escolar, a fim de ser compreendido pelos alunos. Isso fica exemplificado em um dos últimos turnos do episódio:

Prof: Foi mais realista. Isso aqui tá muita fantasia, né? Parece Jurassic Park, né? Ali no Museu do Ipiranga. Tudo bem, então? Isso era pra chamar a atenção. Nós não vamos falar na aula de hoje o que de fato, enfim, aconteceu nessa situação aqui. Provavelmente nós falaremos na aula de amanhã. Mas eu só coloquei aqui pra gente pensar que a independência não foi fácil. Um cara berra e tá tudo feito. Não foi bem assim!

Por isso, o conhecimento histórico escolar não pode ser considerado nem equivalente ao senso comum, porque trabalha com métodos $\mathrm{e}$ procedimentos que o aproximam do conhecimento científico, mas também não é idêntico à produção acadêmica da História, pois possui objetivos pedagógicos próprios. Os alunos possuem muitos conhecimentos históricos significativos como se observa nas aulas, mas que em geral aparecem de maneira fragmentada e pouco sistematizada. O professor, ao realizar a mediação entre os conhecimentos produzidos na área da História e os alunos, faz muitas concessões, aproximando o seu discurso dos alunos e incorporando elementos estranhos à ciência. Contudo, não é incomum que algum aluno, como $\mathrm{F}$, extrapole o tema da aula, e traga elementos de análises científicas para as aulas de História. Nesse sentido, a escola não é o único espaço de constituição de consciência histórica, mas é um espaço privilegiado de sistematização desses conhecimentos e de uma maior racionalização na experiência histórica desses sujeitos. 
Os alunos não apenas adquirem conhecimento pela interação com 0 professor e os colegas, mas também pela mediação de narrativas cuja origem é anterior a essa aula de História. Se concordarmos com as proposições de Vigotski, para quem o desenvolvimento dos sujeitos possui uma gênese sóciohistórica, mediada pelo outro, pelos signos e pelos instrumentos, podemos pensar que

\begin{abstract}
A mediação não se restringe a outros sujeitos fisicamente presentes, estende-se aos efeitos da incorporação de experiências nas relações sociais, vividas em diferentes contextos e de diferentes modos. A tese de constituição social também abrange uma certa noção de objeto, configurada nas práticas sociais e nos significados circulantes. Basicamente, o conhecer tem gênese nas relações sociais, é produzido na intersubjetividade e é marcado por uma rede complexa de condições culturais (GÓES, 1997, p. 14).
\end{abstract}

No episódio acima, a reprodução em preto e branco de "Independência ou Morte" medeia uma poderosa versão da Independência do Brasil aos alunos, possivelmente já conhecida por muitos deles. O professor pouco leva em consideração que a reprodução do quadro é precária (pequena, pouco nítida, preto e branco), que os alunos talvez não conheçam o Museu Paulista, que talvez não tenham a dimensão da distância histórica entre o ano da Independência e o término da pintura. Essas lacunas podem ter trazido alguma confusão entre os alunos. No entanto, a imagem, ainda prejudicada pelo suporte, medeia uma série de informações: os personagens principais do acontecimento, o local, as vestimentas, a monumentalidade do "grito". A imagem, por sua vez, é também mediada pelos sujeitos da sala: o professor, que tem uma intencionalidade pedagógica, e os alunos, que apresentam suas leituras e comentários sobre a imagem.

Assim, no episódio o professor planeja uma introdução ao conceito "Independência do Brasil", a começar por uma aula em que se pretende problematizar o quadro de Pedro Américo. Conforme o professor faz a leitura da reprodução da obra e os alunos percebem, um tanto surpresos, que a 
pintura não corresponde a uma "verdade histórica", percebe-se nos alunos o quanto as narrativas referentes ao quadro thes eram significativas. Muitos alunos se manifestam nesse sentido, mas a aluna $\mathrm{R}$ (mulher, trabalhadora), que em geral é mais discreta nas outras aulas, nessa participa bastante. Ela em diversos momentos do episódio demonstra estar contrariada com a explicação dada pelo professor, de que a Independência do Brasil não teria ocorrido da maneira como está no quadro. Mais adiante, em diálogo com o professor, ela demonstra conhecer a narrativa do quadro:

Prof: Esses caras todos que tão em volta... Essa cena como eu disse não aconteceu. Mas essa gente... Passou uma tropa aí, com o D. Pedro. Ele tava indo visitar a amante dele em Santos. E ele tava em lombo de mula. Tava todo mundo montado em lombo de mula. Ninguém tava a cavalo. Então só pra vocês saberem que a cena foi inventada pelo pintor. Não tomem isso... Por isso que eu botei ela aqui, pra gente conversar sobre isso. Não tomem isso como uma cena real.

R: Nossa, eu pensava que era assim. Quanto tempo!! Ah, eu pensava que o Brasil tinha sido independente por causa do grito dele lá. E tornou-se independente. Eu pensava que era verdade!

Prof: Mas eu vou te dizer uma coisa, menina.

R: Quando ele gritou: "independência ou morte".

Prof: Aí resolveu tudo!

R: Aí resolveu tudo, o Brasil tornou-se independente. Eu pensava que era!

Na fala da aluna, o Brasil teria se tornado "independente" através dessa narrativa, tendo D. Pedro como herói, como está na imagem. Para ela, a independência do Brasil não consiste em um conceito com determinado significado, mas constitui uma narrativa, com personagens, ocorrida em determinado tempo e lugar. Para Vigotski (2010), ao longo da ontogênese, uma das formas constituídas de pensamento, anterior ao conceitual, é aquele que se dá por complexos, particularmente presente em crianças, mas também em adultos. No pensamento por complexos, o sujeito aprende a utilizar determinado conceito corretamente nas interações, porque seu uso é mediado socialmente, mas o significado ainda é instável, dependendo não de um 
atributo abstrato e generalizável, mas da sua aplicação concreta. Segundo Góes, essa definição vigotskiana

Sugere, portanto, que o pensamento por complexos é marcado pelo narrar, o que se mostra congruente com a vinculação às memórias, às experiências, isto é, com a natureza vivencial do significado das palavras e das coisas [...] (GÓES, 1997, p. 22).

Embora em geral o pensamento por complexos seja associado ao pensamento infantil, não se pode afirmar que ele não exista também na idade adulta. Mesmo em sociedades modernas industrializadas, adultos não pensam o tempo todo por conceitos científicos (OLIVEIRA, 2009). Quando o conceito "Independência do Brasil" é trazido à aula, particularmente acompanhado da mediação da reprodução da pintura de Pedro Américo, a aluna $R$ sabe do que se trata, conhece o tema, é capaz de trazer elementos da versão histórica veiculada no quadro. $O$ fato de não separar a imagem (a reprodução da pintura) de seu referente (o processo de independência em si), produzindo uma elaboração narrativa, afetiva e ligada à sua experiência e memória, nos leva a crer que possivelmente $\mathrm{R}$ iniciou a aula pensando por complexos o conceito "independência".

Ao longo do episódio, porém, ela demonstra contrariedade ao perceber que o professor oferecia outra leitura do quadro. Em quase todos os turnos do episódio, o professor argumenta que a Independência do Brasil não foi como Pedro Américo pintou no quadro. Reforçado pela sua autoridade, ele se esforça em pacientemente explicar aos alunos que a independência não poderia ter ocorrido factualmente daquela maneira, e traz ainda elementos do contexto histórico de produção da pintura. De uma maneira muito sutil, outra aluna, F, traz ainda uma terceira fala sobre a independência: uma nação independente comercializa diretamente com as outras ("Independente foi quando ele começou a vender as coisas"). Essa multiplicidade de visões (pelo menos três no episódio) sobre um mesmo conceito (Independência do Brasil) é algo 
próprio da escolarização, raramente ocorrendo nas demais práticas cotidianas dos alunos. A escolarização, como tem sido realizada historicamente, possibilita a contraposição entre interpretações diferentes sobre o mesmo objeto do conhecimento, permitindo a reflexão sobre os significados, as teorias e o próprio pensamento.

Para Tulviste (1991), embora a escola não seja capaz de reproduzir todas as condições de produção de conhecimento científico, ela demanda um método de pensamento próprio de sociedades industrializadas, que consiste na formação do pensamento por conceitos científicos de que falava Vigotski. Uma das características desse método de pensamento, constituído social e historicamente, consiste em pensar mais de uma interpretação para o mesmo referente, tornando o próprio sistema de significações um objeto de reflexão, ainda que algumas vezes apareça como uma verdade cristalizada. Para o autor,

\footnotetext{
Uma outra possível razão para as mudanças na autoconsciência consiste no seguinte: ciência, aparentemente mais que outro tipo de atividade, requer que uma pessoa compare seu próprio ponto de vista com o dos outros. Esse é o resultado da essência da atividade científica onde o valor das afirmações ou teorias é determinado pelo quanto elas explicam um fenômeno melhor que as teorias já existentes (TULVISTE, 1991, p. 170, tradução nossa).
}

A escolarização normalmente demanda o estudo de objetos de conhecimento que muitas vezes estão ausentes concretamente do cotidiano dos sujeitos, a partir de elementos do pensamento científico que, embora não sejam capazes de reproduzir completamente as metodologias de produção de conhecimento científico (e nem é o seu papel), tendem a possibilitar o debate sobre um conceito por mais de um ponto de vista. Ainda que muitos rituais escolares muitas vezes dificultem uma formação do pensamento conceitual mais elaborada (EDWARDS; MERCER, 1988), em geral, muitas práticas escolares que explicitam a alteridade de ideias possibilitam que o pensamento 
dos sujeitos adquira um caráter metacognitivo, de reflexão sobre o pensamento em si, sobre os conceitos e as teorias. No episódio em questão, a aluna $R$ parece tomar consciência da sua forma de pensar Independência do Brasil a partir da discussão sobre o tema:

R: Nossa, eu pensava que era assim. Quanto tempo!! Ah, eu pensava que o Brasil tinha sido independente por causa do grito dele lá. E tornou-se independente. Eu pensava que era verdade!

Ao possibilitar diferentes sentidos e significados para o mesmo conceito, a aula se torna uma prática social que possibilita a formação do pensamento conceitual, na medida em que demanda uma separação entre significado e referente no processo de elaboração conceitual (TULVISTE, 1991), no caso entre a Independência do Brasil e suas diferentes versões e interpretações. Somente quando a aluna $\mathrm{R}$ interage com outros discursos sobre a independência, percebe que a sua forma de pensar esse acontecimento histórico (bastante identificada com a pintura de Pedro Américo), é uma versão da História. Embora não se possa afirmar que nessa aula em particular ela tenha se apropriado das formas de significação do pensamento científico, com certeza a aula de História the possibilitou comparar diferentes sentidos e significados da Independência do Brasil.

Para Vigotski, a tomada de consciência sobre os próprios processos mentais está intimamente relacionada à formação do pensamento conceitual:

Nesse processo manifesta-se em primeiro lugar o papel decisivo do ensino. Os conceitos científicos - com sua relação inteiramente distinta do objeto -, mediados por outros conceitos - com seu sistema hierárquico interior de inter-relações -, são o campo em que a tomada de consciência dos conceitos, ou melhor, a sua generalização e sua apreensão parecem surgir antes de qualquer coisa. Assim surgida em um campo do pensamento, a nova estrutura da generalização, como qualquer estrutura, é posteriormente transferida como um princípio de atividade sem nenhuma memorização para todos os outros 
campos do pensamento e dos conceitos. Desse modo, a tomada de consciência passa pelos portões dos conceitos científicos (VIGOTSKI, 2010, p. 290).

Ao problematizar os sentidos e significações em torno do conceito "independência", a mediação pedagógica intencional do professor possibilitou um início de um processo de tomada de consciência sobre as diferentes interpretações do processo de Independência do Brasil, nos alunos. Se por um lado, não há como se afirmar que a aluna $R$ internalizou plenamente formas de significação próprias do pensamento científico, por outro a mediação de elementos do conhecimento histórico sistematizado e a própria situação de debate em sala de aula aparentemente lhe propiciaram o início de uma tomada de consciência em relação ao seu pensamento. Esse processo é importante, pois é a partir daí que se passa a pensar o objeto a partir do conceito, e não 0 contrário.

Entretanto, a fala de outra aluna também chama a atenção. $F$ é bem discreta, embora em sala pareça sempre bem atenta; no episódio em questão se manifesta apenas uma vez. No entanto, seu comentário dirigido à sala e comentado pelo professor, simples na forma, traz elementos de pensamento científico:

F: Independente foi quando ele começou a vender as coisas, né?

Prof: Isso! Nós vamos chegar aí, F! Nós vamos chegar aí.

Aparentemente, $\mathrm{F}$ percebe que o professor está introduzindo o conceito "independência", e traz um atributo específico desse conceito: uma nação se torna independente quando, a partir de um governo e um Estado nacional, tem liberdade de realizar comércio com outras nações sem o monopólio comercial da metrópole (Portugal). No entanto, o professor não explora o comentário da aluna, e prioriza a leitura da obra de Pedro Américo. Quando ele responde que 
"nós vamos chegar aí", dá a entender que o que $\mathrm{F}$ disse está correto, mas ainda será melhor discutido, em aulas futuras. Concordamos com Edwards e Mercer (1988) a respeito dos rituais próprios da escolarização, que muitas vezes são contraproducentes para a constituição de um conhecimento compartilhado, como a pouca clareza das sequências didáticas para os alunos, e a ocultação de determinados conteúdos por estarem fora do planejamento previamente realizado. A aluna $F$ demonstra elementos de conhecimento científico em sua fala, mas não encontra espaço na aula para que a sua voz seja legitimada, não conseguindo explicitar seus argumentos para os colegas ou avançar em suas próprias elaborações.

Algumas considerações sobre os episódios. O espaço escolar constitui um espaço importantíssimo de elaboração conceitual, por possibilitar que os sujeitos que dele participam possam produzir e discutir sentidos e significados acerca de determinados objetos dos conhecimentos - por exemplo, a "Independência do Brasil" - que não necessariamente estão presentes concretamente nas práticas sociais cotidianas dos alunos. Como a relação dos sujeitos com o mundo é mediada por discursos ideológicos, a escola se torna também um espaço privilegiado para o debate entre diversas visões de mundo; a aula de História, por sua vez, se torna um fórum de discussões sobre as várias interpretações que o passado pode receber. A relação dos sujeitos com o passado é sempre mediada por uma consciência histórica.

Para a Teoria Histórico-Cultural, o desenvolvimento dos sujeitos não é evolutivo ou linear, mas constituído culturalmente, a partir de práticas societárias como a escolarização. Nesse sentido, a escola - e nesse caso mais especificamente, a aula de História - parece ser um espaço significativo de elaboração conceitual, por possibilitar formas de pensamento que constituam diferentes sentidos e significados. O objetivo da mediação pedagógica seria, pois, mediar as relações entre teorias, propor métodos de conhecimento da realidade. Contudo, como a relação dos sujeitos com esses conhecimentos é indireta, mediada pela própria prática da escolarização, esse processo de desenvolvimento ocorre com muitas contradições, não garantindo a formação 
do pensamento científico nas aulas de História da mesma maneira para todos os alunos.

Assim, as aulas aparentemente não transcorrem de maneira tão diferente das que usualmente se podem encontrar nas demais escolas com EJA, ou até mesmo em aulas de História no ensino regular. Pelo contrário: mesmo quando muda o professor (por exemplo, quando o coordenador pedagógico substituiu o professor titular de História da turma), não se percebem grandes diferenças na didática. Aparentemente, as aulas de História no CIEJA pouco se diferenciam das aulas de História fora dessa modalidade de escola para a EJA. 


\section{Considerações finais}

A insuficiência das políticas públicas em combater a evasão escolar e o analfabetismo nas últimas décadas tem resultado em um expressivo número de jovens e adultos que não consegue concluir o Ensino Fundamental e Médio, sendo privados de uma educação formal pela escolarização. Embora a oferta de cursos de Educação de Jovens e Adultos seja insuficiente para atender às necessidades dessa população, esses sujeitos se encontram em uma sociedade letrada, burocratizada, urbanizada, que constantemente demanda operações mentais típicas de sociedades contemporâneas industrializadas.

O pouco acesso à escola contrasta com a aquisição de saberes, complexos e significativos, por parte desses sujeitos, a partir das relações sociais das quais participam. Assim, poderíamos nos questionar: de que maneira uma experiência conflituosa e descontínua com a escola interfere negativamente no desenvolvimento desses sujeitos, privados de direitos? 0 problema desse questionamento é a visão um tanto preconceituosa de que o sujeito pouco escolarizado seria deficitário em seu desenvolvimento psicológico, menosprezando as transformações pelas quais passam, e os conhecimentos por eles produzidos.

Portanto, podemos considerar que sujeitos pouco escolarizados constroem significativos saberes a partir de suas vivências cotidianas, inclusive constituindo pensamento conceitual. Contudo, a valorização do conhecimento dos alunos não pode nos levar a desconsiderar as contribuições que a escolarização pode trazer em termos de desenvolvimento para esses sujeitos. Nesse caso, se relativizaria a importância da EJA como política pública para amplos setores das camadas populares. A escola segue como uma importante instituição que promove a sistematização de certos conceitos, relacionando-os a teorias e possibilitando generalizações.

A pesquisa realizada no CIEJA Jéssica Nunes Herculano tinha como objetivo, a partir de um estudo de caso, a investigação da constituição do pensamento conceitual em aulas de História. A análise dos discursos 
ideológicos em sala de aula a partir de Bakhtin e de autores da Psicologia Discursiva como Derek Edwards, bem como o estudo etnográfico da unidade escolar em questão, nos ajudaram a compreender as práticas sócio-discursivas da escola como interações que criam, reinventam e disputam sentidos e significados sobre o passado histórico. Abre-se nessas perspectivas, a partir do contexto escolar, um interessante espaço de compreensão das negociações de visões de mundo e maneiras de ser e estar, onde a mediação pedagógica constitui determinados conceitos da História em sala de aula.

Nesse trabalho, optou-se pela Teoria Histórico-Cultural, tendo os escritos de Vigotski e outros autores dessa perspectiva, como o principal aporte teórico para as questões sobre o desenvolvimento humano. Pensamos o aluno da EJA não como um sujeito limitado para os estudos por razões inatas ou determinadas socialmente, mas como alguém cujo desenvolvimento cognitivo deu-se em um contexto sócio-histórico específico. Muitas seriam as situações que demandariam transformações para os adultos: as mudanças no mundo do trabalho, relacionadas às mudanças na economia; as migrações e mudanças de domicílio; a cultura religiosa, a formação e separação de famílias e relações afetivas, a perda de parentes e amigos, etc. Dessa maneira, como seria possível que o jovem e o adulto não passassem por mudanças importantes? Neste trabalho em particular, pensamos que o próprio retorno à escolarização pode ser um momento de transformação para os sujeitos, constituindo neles formas de pensar próprias da escolarização como o pensamento conceitual.

A teoria de Vigotski a respeito do pensamento ao longo do desenvolvimento humano instiga muitas reflexões sobre os processos desses alunos. De acordo com o autor bielo-russo e outros autores da Teoria HistóricoCultural, o desenvolvimento das formas de pensamento ao longo da ontogênese, do pensamento sincrético ao conceitual, não se dá de maneira evolutiva, mas por crises e revoluções, permitindo inclusive que no indivíduo adulto diferentes formas de pensamento coexistam. $O$ desenvolvimento do pensamento é mediado pelas relações sociais, sendo a escolarização um importante espaço de construção de maneiras de pensar mais organizadas, 
sistematizadas, descontextualizadas. Esse tipo de pensamento, chamado por Vigotski de científico ou sistematizado, propiciaria a metacognição, a reflexão do pensamento em si, como instrumento intelectual de interpretação do mundo.

Nesse sentido, uma das constatações mais importantes da pesquisa foi o fato de que em um contexto de escolarização formal, a constituição de pensamento conceitual é possibilitada pela maneira como se dão as interações em sala de aula entre professores e alunos. A seleção consciente de um objeto do conhecimento ausente concretamente da sala de aula, em geral um conjunto de conceitos organizados didaticamente pelo professor de História, e a sua elaboração intersubjetiva pelos alunos e professores, possibilita uma atividade metacognitiva, problematizando teoricamente os conceitos trazidos para a aula.

A maior experiência dos alunos da EJA com situações do mundo adulto como o trabalho e a sua relação com algumas culturas jovens urbanas thes possibilitam um repertório bem diferente das crianças. Esses alunos trazem evidentemente muitos conceitos espontâneos sobre a sua experiência social, ou seja, conceitos que foram apropriados em práticas sociais cotidianas, e não em um contexto de escolarização. No entanto, ainda que não sistematizados, esses conceitos espontâneos são bem mais complexos do que os das crianças. Percebemos que os conceitos espontâneos dos alunos da EJA aparecem fortemente nas aulas, e se relacionam aos conceitos sistematizados das aulas mediados pelo professor e pelos materiais didáticos. A mediação pedagógica intencional do professor em um contexto de escolarização possibilita a constituição de um conhecimento compartilhado, que a partir da interação entre sujeitos em cooperação, atua na Zona de Desenvolvimento Proximal dos sujeitos, em um processo de formação de pensamento conceitual nas aulas de História. Como a gênese dessa operação está nas interações em sala de aula, a constituição de pensamento conceitual se dá de maneira particular em cada sujeito.

No entanto, a construção de um conhecimento compartilhado sofre a interferência de rituais escolares que contraditoriamente não contribuem para a 
construção de um pensamento científico. Dessa maneira, a partir da análise dos episódios, também concluímos que, apesar de a escola possibilitar a formação de pensamento conceitual, ela também possui uma série de rituais contraproducentes para uma maior instrução ou aprendizagem dos alunos. Embora esses rituais não impeçam a constituição do pensamento conceitual, opinamos que dificultam muitas vezes um maior aprofundamento dos conceitos que deveriam ser trabalhados com os alunos. Entre as práticas que dificultam uma mediação pedagógica mais adequada estão: a pouca valorização dos conceitos espontâneos dos alunos no espaço escolar; a falta de clareza para os alunos a respeito de diversos procedimentos da escola; a ocultação de conteúdos que poderiam ser discutidos, mas são considerados fora do planejamento de determinadas aulas; o planejamento previamente realizado e que não é alterado de acordo com as necessidades dos alunos, entre outras.

A sociedade contemporânea está permeada por diversas formas de consciência histórica, que se constituem fora e dentro da escola. A História parece ser parte da cultura, sendo amplamente divulgada de acordo com diversos interesses. Mas é na escola que ela é estudada com suas características de conhecimento sistematizado, a partir de métodos e teorias. A nossa hipótese é que a consciência histórica que tem sido trazida pelos alunos da EJA, a partir das suas experiências sociais está relacionada ao que Vigotski chamava de conceitos espontâneos, e o Ensino de História que tem sido oferecido a eles, embora contribua de alguma forma no sentido de oferecer mais elementos para a constituição da consciência histórica, nem sempre dá conta de ampliar de maneira satisfatória os significados e sentidos da experiência vicária com o passado, correndo o risco de se reduzir a um questionamento sobre as possíveis versões da História, nem sempre mediando um conhecimento histórico sistematizado mais aprofundado. Mesmo assim, não são pouco significativos os conceitos históricos estudados em sala de aula, que provavelmente não seriam trazidos daquela maneira, com determinado método de pensamento, em outro lugar. A escola possibilita, de alguma forma, a mediação de um conhecimento histórico mais sistematizado e com elementos importantes de produção científica. 
A compreensão de como se dão as interações dos sujeitos em sala de aula, em componentes curriculares específicos como a História, é importante para fornecer elementos para a tomada de decisões em termos de políticas públicas, em um momento em que a diminuição das matrículas de jovens e adultos constitui uma negação da possibilidade de amplos setores das camadas populares de terem acesso ao processo de escolarização. Ressaltase também que a discussão sobre os currículos de História para a educação pública leva pouco em consideração as necessidades das populações locais, seus conceitos cotidianos e sua consciência histórica, como constitutivos de qualquer parâmetro nacional que se queira oferecer. 


\section{Referências bibliográficas}

A MISSÃO. Direção: Rolland Joffé. Reino Unido: Warner Bros, 1986. 1 DVD (126 min), color. Título original: The Mission.

ABSW: Associação Brasileira da Síndrome de Williams. Jéssica Nunes - SP. Disponível em: http://swbrasil.org.br/relatos/jessica-nunes-sao-paulosp/. Acesso em 19/07/17.

ALVAREZ, A.; RIO, P. del. In: VYGOTSKY, L. S. Obras escogidas I: incluye el significado histórico de la crisis de la psicología. Trad. José María Bravo. Madrid: Centro de Publicaciones del M.E.C. e Visor Distribuciones, 1991, p. XIII-XXVI.

ALVARO, J. L.; GARRIDO, A. Psicologia social: perspectivas psicológicas y sociológicas. Madrid: Mc.Graw Hill, 2003.

ALVES, Ronaldo Cardoso. Da consciência histórica (pré)(pós?) moderna: reflexões a partir do pensamento de Reinhardt Kosseleck. sÆEculum - REVISTA DE HISTÓRIA [30] João Pessoa, jan./jun. 2014.

ANDRÉ, Marli Eliza D. A. Etnografia da prática escolar. Campinas: Papirus Editora, 1995.

ATTIAS-DONFUT, Claudine. La notion de génération - Usages sociaux et concept sociologique. L'Homme et la société. 1988, número 90.

BAKHTIN, Mikhail; VOLOCHÍNOV. Marxismo e filosofia da linguagem. Trad. Michel Lahud e Yara Frateschi Vieira. São Paulo: Hucitec Editora, 2014.

BARCA, Isabel. Educação Histórica: uma nova área de comunicação. Revista da Faculdade de Letras: História. Porto, III Série, vol. 2, 2001, p. 31-21.

BARROS FILHO, Delma; BASTOS, Ana Cecília de Souza B. A Formação de conceitos em adultos não escolarizados. Educação e Pesquisa, São Paulo, v. 41, no 3, p. 647-662, jul./set. 2015.

BEAUD, Stéphane; PIALOUX, Michel. Retour sur la condition ouvrière. [S.I.]: Fayard, 1999.

BERGMANN, Klaus. A História na reflexão didática. Handbush der Geschichtsdidaktik. Trad. Augustin Wemmet. Düsseldorf: Schwann-Verlag, 1985, p. 207-217.

BILLIGS, M. Social psychology and intergroup relations. London: Academic Press, 1976.

BRAIT, Beth (Org.). Bakhtin: conceitos-chave. São Paulo: Contexto, 2005. 
BRASIL. Instituto Nacional de Estudos e Pesquisas Educacionais Anísio Teixeira. A Avaliação da EJA no Brasil: insumos, processos, resultados. Brasília, $2015 . \quad$ № $39 . \quad$ Disponível em: http://www.publicacoes.inep.gov.br/portal/download/1141. Acesso em: julho de 2017.

. Lei ํo 9,394, de 20 de dezembro de 1996. Estabelece as diretrizes e bases da educação nacional. Brasília, 1996. Disponível em: http://www.planalto.gov.br/ccivil 03/leis/L9394.htm. Acesso em: julho de 2017.

Instituto Nacional de Estudos e Pesquisas Educacionais Anísio Teixeira. Disponivel em: http://portal.inep.gov.br/web/guest/inicio. Acesso em: julho de 2017.

. Plano Nacional de Educação - lei oㅜ 10.172, de 9 de janeiro de 2001, aprova o Plano Nacional de Educação e dá outras providências. Disponível em: http://www.planalto.gov.br/ccivil 03/leis/leis 2001/l10172.htm. Acesso em: julho de 2017.

. Plano Nacional de Educação - lei oㅜ 13.005, de 25 de junho de 2014, aprova o Plano Nacional de Educação - PNE e dá outras providências. Disponível em: $\quad$ http://www.planalto.gov.br/ccivil 03/ ato20112014/2014/lei//13005.htm. Acesso em: julho de 2017.

CAMARGO, Giovana Azzi de. A tensão entre o oral e o escrito na alfabetização de jovens e adultos: um estudo / um olhar. Itatiba, 2006. Dissertação (Mestrado). Educação, Universidade São Francisco.

CARRETERO, Mario; LIMÓN, Margarita. Problemas atuais do construtivismo: da teoria à prática. In: RODRIGO, Maria José; ARNAY, José (org.). Conhecimento cotidiano, escolar e científico: representação e mudança. Trad. Cláudia Schilling. São Paulo: Editora Ática, 1997, p. 171-190.

CHAIKLIN, Seth. A zona de desenvolvimento próximo na análise de Vigotski sobre aprendizagem e ensino. Psicologia em estudo, Maringá, volume 16, ํㅡ 4, 2011. Disponível em: http://dx.doi.org/10.1590/S1413-73722011000400016. Acesso em: agosto de 2014.

COLE, Michael. Desenvolvimento cognitivo e escolarização formal: a evidência da pesquisa transcultural. In: MOLL, Luís C. (Org.). Vygotsky e a educação: implicações pedagógicas da psicologia sócio-histórica. Porto Alegre: Artmed, 1996. p. 85-105.

in: LURIA, A. R. Desenvolvimento Cognitivo: seus fundamentos culturais e sociais. São Paulo: Ícone, 1990, p. 11-16.

; SCRIBNER, Sylvia. Prefácio. In: VIGOTSKI, L. S.. A formação social da mente. 6⿳亠丷厂 edição. São Paulo: Martins Fontes, 2000, p. 1-19. 
DUARTE, L. F. D.; GOMES, E. C. Três famílias: identidades e trajetórias transgeracionais nas classes populares. Rio de Janeiro: Editora FGV, 2008.

DI PIERRO, Maria Clara. A Educação de Jovens e Adultos no Plano Nacional de Educação: Avaliação, desafios e perspectivas. Educação \& Sociedade, Campinas, v. 31, n. 112, p. 939-959, jul.-set. 2010. Disponível em: http://www.producao.usp.br/bitstream/handle/BDPI/6395/art DI PIERRO A ed ucacao de jovens e adultos no 2010.pdf?sequence $=1$. Acesso em 23 Jul. 2017.

. Dados Básicos Sobre a Educação Básica de Jovens e Adultos. In: CONFERÊNCIA NACIONAL DE EDUCAÇÃO BÁSICA, 2008. Brasília. Disponível em: http://portal.mec.gov.br/arquivos/conferencia/documentos/maria di pierro.pdf. Acessado em: 23 jul. 2017.

EDWARDS, Derek. Em direção a uma psicologia do discurso da educação em sala de aula. In: COLL, César; EDWARDS, Derek. (Org.). Ensino, aprendizagem e discurso em sala de aula. Trad. Beatriz Affonso Neves. Porto Alegre: ArtMed, 1998, p. 47-74.

; MERCER, Neil. El conocimiento compartido: el desarrollo de la comprensión en el aula. Trad. Ramón Alonso. Barcelona: Ediciones Paidós Barcelona - Buenos Aires - Mexico, 1988.

ENGELS, Friedrich; MARX, Karl. A ideologia alemã: crítica da mais recente ideologia alemã em seus representantes Feuerbach, B. Bauer, Stiner, e do socialismo alemão em seus diferentes profetas. Trad. Luciano Cavini Martorano. São Paulo: Boitempo, 2007.

FAIRCLOUGH, Norman. Discurso e mudança social. Trad. Discourse and social change. Brasília: Editora UNB, 2001.

FARACO, C. A. Linguagem e diálogo: as ideias linguísticas do círculo de Bakhtin. Curitiba: Criar Edições, 2003.

FIORIN, José Luiz. Interdiscursividade e intertextualidade. In: BRAIT, Beth (Org.). Bakhtin: outros conceitos-chave. São Paulo: Contexto, 2006, p. 161193.

FONTANA, Roseli Aparecida Cação. Mediação pedagógica em sala de aula. 4⿳亠丷a edição. Campinas: Autores Associados, 2005.

FONSECA, Maria da Conceição F. R. Educação matemática de jovens e adultos: especificidades, desafios e contribuições. Belo Horizonte: Autêntica Editora, 2002.

GERALDI, João Wanderley. A aula como acontecimento. São Carlos: Pedro e João Editores, 2010. 
GODEIRO, Nazareno; GURGEL, Amanda. A quem serve a crise da educação brasileira? Uma análise da realidade educacional no Brasil e no RN. São Paulo: ILAESE, 2015.

GÓES, Maria Cecília Rafael de. A abordagem microgenética na matriz histórico-cultural: uma perspectiva para 0 estudo da constituição da subjetividade. Caderno CEDES, ano XX, ํo 50, abril/00, p. 9-25.

SMOLKA, A. L. B. (Org.). A significação nos espaços educacionais: interação social e subjetivação. $1^{\text {a }}$ ed. Campinas: PAPIRUS, 1997.

; CRUZ, Maria Nazaré da. Sentido, significado e conceito: contribuições de Lev S. Vigotski. Pro-Posições, v. 17, n. 2 (50) maio/ago. 2006.

HADDAD, Sérgio; DI PIERRO, Maria Clara. Escolarização de jovens e adultos. Rev. Bras. Educ. [online], n.14, p.108-130, 2000. Disponível em: http://www.scielo.br/scielo.php?pid=S1413-

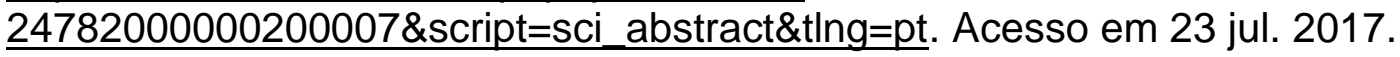

HERCULANO, Jéssica Nunes. Jéssica Nunes - SP. Disponível em: http://swbrasil.org.br/relatos/jessica-nunes-sao-paulosp/. Acessado em: julho de 2017.

HOBSBAWN, Eric. Era dos extremos: O breve século XX: 1914-1991. Trad. Marcos Santarrita. 2ª edição. São Paulo: Companhia das Letras, 2007.

INDURSKY, Freda. Relatório Pinotti: o jogo polifônico das representações no ato de argumentar. In: GUIMARÃES, Eduardo (Org.). História e sentido na linguagem. Campinas: Pontes, 1989, p. 93-127.

INHELDER, Bärbel.; PIAGET, Jean. Da lógica da criança à lógica do adolescente: ensaio sobre a construção das estruturas operatórias formais. São Paulo: Livraria Pioneira Editora, 1976.

KLEIMAN, Angela B.. Modelos de letramento e as práticas de alfabetização na escola. In: KLEIMAN, Angela B.. Os significados do letramento. Campinas: Mercado de Letras, 1995.

; SIGNORINI, Inês. O ensino e a formação do professor: alfabetização de jovens e adultos. $2^{\underline{a}}$ Edição Revista. São Paulo: Editora Artes Médicas Sul, 2001.

KOSELLECK, Reinhart. Futuro Passado: Contribuição à semântica dos tempos históricos. Trad. Wilma Patrícia Maas; Carlos Almeida Pereira. Rio de Janeiro: Contraponto-Ed. PUC-Rio, 2006. 
LAUTIEUR, Nicole. Os saberes históricos em situação escolar: circulação, transformação e adaptação. Educação e realidade, Porto Alegre: v. 36, n. 1, p. 39-58, jan./abr. 2011. Disponível em: http://www.ufrgs.br/edu realidade. Acessado em jul/17.

LEE, Paul. Por que aprender história? Educar em revista, Curitiba: Editora UFPR, n. 42, p. 19-42, out/dez 2011.

LÜDKE, Menga; ANDRÉ, Marli Eliza D. A. Pesquisa em Educação: abordagens qualitativas. São Paulo: Editora Pedagógica e Universitária LTDA, 1986.

LURIA, A. R. Desenvolvimento Cognitivo: seus fundamentos culturais e sociais. São Paulo: Ícone, 1990.

MACHADO, Irene. Gêneros discursivos. In; BRAIT, Beth (Org.). Bakhtin: conceitos-chave. São Paulo: Contexto, 2006, p. 151-166.

MANNHEIM, Karl. 1993. "El problema de las generaciones", Revista Española de Investigaciones Sociológicas (REIS), n. 62, p. 193-242.

MARCHEZAN, Renata Coelho. Diálogo. In: BRAIT, Beth (Org.). Bakhtin: outros conceitos-chave. São Paulo: Contexto, 2006, p. 115-131.

MEIRELES, Cecília. Romanceiro da Independência. LP\&M POCKET. 2008, p. 91.

MERCER, Neil. As perspectivas socioculturais e o estudo do discurso em sala de aula. In: COLL, César; EDWARDS, Derek (Org.). Ensino, aprendizagem e discurso em sala de aula. Trad. Beatriz Affonso Neves. Porto Alegre: ArtMed, 1998, p. 13-28.

MIOTELLO, Valdemir. Ideologia. In: Bakhtin conceitos chave. BRAIT, Beth (org.). São Paulo: Editora Contexto, 2005. p. 167-176.

MOTTA, Alda Britto da. A atualidade do conceito de gerações na pesquisa sobre o envelhecimento. Sociedade e Estado. 2010, vol.25, n.2, p. 225-250.

MOURA, Mayra Patrícia. A organização conceitual em adultos pouco escolarizados. In: OLIVEIRA, Marcos Barbosa de; OLIVEIRA, Marta Kohl de (Org.) Investigações cognitivas: conceitos, linguagem e cultura. Porto Alegre: Artes Médicas Sul, 1999, p. 101-113.

NOGUEIRA, Ana Lúcia Horta. As normas e as práticas discursivas nas relações de ensino. In: SMOLKA, A. L. B.; NOGUEIRA, A. L. H. (Org). Questões de desenvolvimento humano: práticas e sentidos. Campinas: Mercado de Letras, 2010, p. 57-80. 
OLIVEIRA, Marta Kohl de. Ciclos de vida: algumas questões sobre a psicologia do adulto. Educação e pesquisa, maio-agosto, ano 2004, vol. 30 número 002. Universidade de São Paulo, São Paulo - Brasil, p. 211-229.

desenvolvimento do adulto. São Paulo: Hucitec, 2009.

Cultura e psicologia: questões sobre o . Jovens e adultos como sujeitos de conhecimento e aprendizagem. Trabalho apresentado na XXII Reunião Anual da ANPED, Caxambu, setembro de 1999.

ORLANDI, E. P. Interpretação: autoria, leitura e efeitos do trabalho simbólico. Petrópolis: Vozes, 1996.

PATTO, M. H. S.. Psicologia e ideologia: uma introdução crítica à psicologia escolar. São Paulo: T. A. Queiroz, 1984.

PROJETO POLÍTICO PEDAGÓGICO. São Paulo: CIEJA Jéssica Nunes Herculano, 2016.

REGO, Teresa Cristina. Vygotsky: uma perspectiva histórico-cultural da Educação. 22를 ed. Petrópolis: Editora Vozes, 1994.

ROCKWEEL, Elsie. In: EZPELETA, Justa; ROCKWELL, E. Pesquisa participante. São Paulo: Cortez Editora, 1986.

SANTOS, Wildson Luiz Pereira dos; MORTIMER, Eduardo Fleury. Uma análise de pressupostos teóricos da abordagem C-T-S (Ciência-Tecnologia-Sociedade) no contexto da educação brasileira. Ensaio - Pesquisa em educação em ciências. [S.I.]: Sistema de Informação Científica Rede de Revistas Científicas da América Latina, Caribe, Espanha e Portugal, vol. 2, no 2. Disponível em: http://ufpa.br/ensinofts/artigos2/wildsoneduardo.pdf. Acesso em: agosto de 2017.

SÃO PAULO. As Cinco Formas de Atendimento da Educação de Jovens e Adultosna Cidade de São Paulo. Disponível em: http://portalsme.prefeitura.sp.gov.br/Main/Page/PortalSMESP/Formas-deAtendimento. Acesso em: julho de 2017.

CIEJA Jéssica Nunes Herculano. Disponível em: http://eolgerenciamento.prefeitura.sp.gov.br/frmgerencial/NumerosEscola.aspx? Cod=200158. Acesso em: dezembro de 2015.

Educação de Jovens e Adultos: Princípios e práticas pedagógicas - 2015. São Paulo: Secretaria Municipal de Educação, 2016. Disponível em: http://portal.sme.prefeitura.sp.gov.br/Main/Noticia/Visualizar/PortalSMESP/Educ acao-de-Jovens-e-Adultos-principios-e-praticas-pedagogicas--2015. Acesso em: julho de 2017. 
. Reorganização da EJA - Educação de Jovens e Adultos: Rede Municipal de Ensino de São Paulo. São Paulo: Secretaria Municipal de Educação, $2008 . \quad$ Disponível em: http://portal.sme.prefeitura.sp.gov.br/Portals/1/Files/16117.pdf. Acesso em: julho de 2017.

SILVA, Wilson Honório da. O Mito da Democracia Racial: um debate marxista sobre raça, classe e identidade. São Paulo: Sundermann, 2016.

SMOLKA, A. L. B. Experiência e discurso como lugares de memória: a escola e a produção de lugares comuns. Pró-Posições (UNICAMP, impresso), v. 17, 2006, p. 99-118.

. O (Im)próprio e o (im)pertinente na apropriação das práticas sociais. Caderno Cedes, ano XX, no 50 , abril/00, p. 26-40.

Sobre significação e sentido: uma contribuição à proposta da rede de significações. In: ROSSETI-FERREIRA, M. C.; AMORIM, K. S.; SILVA, A. P. S.; CARVALHO, A. M. A. (org.). Rede de significações e o estudo do desenvolvimento humano. Porto Alegre: Art Med, 2004, p. 35-50.

TULVISTE, Peeter. The Cultural-Historical Development of Verbal Thinking. Trad. Marie Jaroszewska Hall. Commack, N. Y.: Nova Science Publishers, 1991.

TUTIOUX-GILLON, Nicole. O paradoxo francês: cultura histórica significativa e didática da história incerta. Educação e realidade, Porto Alegre: v. 36, n. 1, p. 15-37, jan/abr. 2011. Disponível em: http://www.ufrgs.br/edu realidade.

VALSINER, Jaan. Indeterminação restrita nos processos de discurso. In: COLL, César; EDWARDS, Derek (Org.). Ensino, aprendizagem e discurso em sala de aula. Trad. Beatriz Affonso Neves. Porto Alegre: ArtMed, 1998, p. 29-46.

VIGOSTSKI, L. S.. A construção do pensamento e da linguagem. Tradução: Paulo Bezerra. São Paulo: Martins Fontes, 2010.

. A formação social da mente. $6^{\text {a }}$ edição. Trad. José Cipolla Neto, Luis Silveira Menna Barreto, Solange Castro Afeche. São Paulo: Martins Fontes, 2003.

. Imaginação e criação na infância. (Apresentação e comentários Ana Luiza Smolka). Tradução: Zoia Prestes. São Paulo: Ática, 2009.

. Pensamento e linguagem. 2. ed. São Paulo: Martins Fontes, 2004.

VÓVIO, Cláudia Lemos. Duas modalidades de pensamento: pensamento narrativo e pensamento lógico-científico. In: OLIVEIRA, Marcos Barbosa de; OLIVEIRA, Marta Kohl de (Org.) Investigações cognitivas: conceitos, linguagem e cultura. Porto Alegre: Artes Médicas Sul, 1999, p. 115-142. 
Textos narrativos orais e escritos produzidos por jovens e adultos em processo de escolarização. São Paulo, 1999. 237 p. Dissertação (Mestrado). História e filosofia da educação, Educação de Jovens e Adultos - Faculdade de Educação, Universidade de São Paulo.

VYGOTSKY, L. S. Obras escogidas I: incluye el significado historico de la crisis de la psicología. Trad. José María Bravo. Madrid: Centro de Publicaciones del M.E.C. e Visor Distribuciones, 1991. 